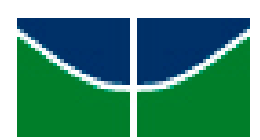

UNIVERSIDADE DE BRASÍLIA - UnB

INSTITUTO DE CIÊNCIAS HUMANAS - IH

DEPARTAMENTO DE GEOGRAFIA - DGEA

PROGRAMA DE PÓS-GRADUAÇÃO EM GEOGRAGIA - PPGEA

MEMÓRIA E TERRITÓRIO:

SOCIOGÊNESE DA LUTA PELA TERRA DOS ASSENTADOS DO CAFUNDÃO (MARIANA-MG).

RÚbia DE PAULA RÚBIO

BRASÍLIA - DF

MARÇO / 2015 


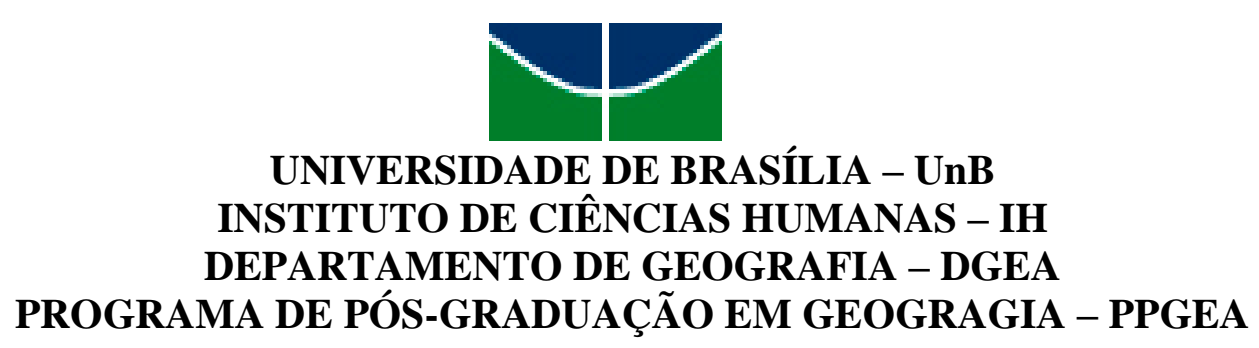

MEMÓRIA E TERRITÓRIO:

SOCIOGÊNESE DA LUTA PELA TERRA DOS ASSENTADOS DO CAFUNDÃO (MARIANA-MG).

Dissertação apresentada ao Departamento de Geografia do Instituto de Ciências Humanas da Universidade de Brasília, para obtenção do título de Mestre em Geografia.

Área de concentração: Organização do Espaço Urbano, Rural e Regional.

Orientador: Prof. Dr. Everaldo Batista da Costa. 


\author{
UNIVERSIDADE DE BRASÍLIA \\ DEPARTAMENTO DE GEOGRAFIA
}

\title{
MEMÓRIA E TERRITÓRIO: SOCIOGÊNESE DA LUTA PELA TERRA DOS ASSENTADOS DO CAFUNDÃO (MARIANA-MG).
}

\author{
RÚBIA DE PAULA RÚBIO
}

Dissertação de Mestrado submetida ao Departamento de Geografia do Instituto de Ciências Humanas da Universidade de Brasília, como parte dos requisitos necessários para a obtenção do Grau de Mestre em Geografia, área de concentração Gestão Ambiental e Territorial.

\section{DATA DA DEFESA: 30 DE MARÇO DE 2015.}

Aprovado por:

Prof. Dr. Everaldo Batista da Costa Instituição: DG-ICH, UnB / Brasília - DF

(Orientador)

Prof. Dra. Bernadete Aparecida Caprioglio de Castro Instituição: IGE-UNESP / Rio Claro-SP

(Membro Externo)

Prof. Dr. Neio Lúcio de Oliveira Campos

Instituição: DG-ICH, UnB / Brasília - DF

(Membro Interno)

BRASÍLIA - DF

MARÇO / 2015 


\section{RÚBIO, Rúbia de Paula.}

Memória e território: sociogênese da luta pela terra dos assentados do Cafundão (Mariana-MG), 229p. (UnB-GEA, Mestre, Gestão Ambiental e Territorial, 2015).

Dissertação de Mestrado - Universidade de Brasília. Departamento de Geografia.

1. Sociogênese de assentamento

2. Ruralidade;

3. Memória e Território

4. Cafundão, MG.

É concedida à Universidade de Brasília permissão para reproduzir cópias desta dissertação. A autora se reserva de outros direitos de publicação. Nenhuma parte desta Dissertação de Mestrado pode ser reproduzida sem a autorização por escrito da referida autora.

Rúbia de Paula Rúbio 
Dedico aos Orientes que nutrem Minh'Alma.

*

"Alma, vai além de tudo que o nosso mundo ousa perceber!" (Zé Renato e Milton Nascimento - 'Anima'). 


\section{AGRADECIMENTOS}

Agradecer... Verbo que invoca sentimento de gratidão, reconhecimento. Às forças em torno de mim, que me nutrem, guiam e orientam - agradeço. A licença dada para se falar em primeira pessoa a algo ou alguém que não sei o que é, um Outro apenas sentido. Apenas não diminui: resume a sensação de estar rodeada. Sons de tambor que ecoam. Isto basta, Exú!

Agradeço aos meus pais, pelas mãos dadas, por ensinar que pés devem andar em chãos pedregosos, com medo, vontade e fé. Por serem, nesta distância escolhida, minha segurança terrena.

Imensamente, reconheço a presença constante do meu Orientador Professor Dr. Everaldo Batista da Costa. Por ter aceito uma mineira recém-chegada em uma cidade do tamanho de seus sonhos. Por fazer-me conterrânea de molduras barrocas: mineiridade é também encontro. Por assumir a tarefa de lapidar procuras... Pelo incentivo, pela humanidade e sensibilidade. Por ser exigente, por valorar quem te circunda. Por nutrir o sonho-desejo de que o Grupo, transfigurado no nome GECIPA, alce voos, percorra cenas, cenários, contextos e se eleve a algo maior. Por fazer da inquietação algo pertencente ao caminho, com tranquilidade, compromisso e movência. Como o nosso Milton Nascimento diria, dispondo sobre Travessia, Solto a voz nas estradas, já não quero parar. Não paremos! Obrigada.

Reconheço, para além deste trabalho, os professores que compuseram minha trajetória de vida e de estudo. Especialmente, ao Professor Ms. Patrício A. P. de Sousa pelo incentivo de construção de geografias, em seu pluralismo, possibilidades, belezas. Por incentivar que se fosse, não necessariamente com certezas de onde se chegaria. Aos demais professores que substanciaram o percurso da graduação em Geografia. Aos professores da UnB e colegas da pósgraduação que adentraram esta travessia no momento de lapidação de pesquisa, em disciplinas, encontros, conversas.

Agradeço aos órgãos públicos, principalmente a EMATER-Mariana, EMATER-MG e Câmara Municipal de Mariana, que contribuíram na concessão de documentos, informações e dados.

Aos assentados, por se desnudarem no reavivamento de suas memórias e por permitir apreender pulsações de vida.

À CAPES, pelo incentivo na concessão da bolsa de pesquisa.

Ao Thomas, por ser cúmplice. La complicidad es tanta, que nuestras vibraciones se complementan... 



\section{RESUMO}

A presente dissertação se relaciona à questão de terras brasileiras, no que concerne ao histórico de desigualdade fundiária que fomenta, dentre outros enfoques, a luta e os movimentos sociais pelo acesso a terra, e a reivindicação da política de reforma agrária enquanto via institucionalizada de promoção deste acesso. Dedica-se, nesta pesquisa, às memórias dos assentados que compõem e revelam a sociogênese de um assentamento de reforma agrária específico que é o Cafundão, localizado em Mariana, cidade histórica de Minas Gerais. A investigação da sociogênese se deu por meio das narrativas dos assentados em diálogo com fontes documentais e reflexões teóricas que contribuem à análise deste contexto. Partiu-se da ideia de que o assentamento de reforma agrária Cafundão integra o contexto de terras mais amplo que lhe dá substância e sentido, e admite-se enquanto inquirição as narrativas que os assentados fazem da história de luta pela terra que deu origem a esse assentamento. Norteou-se pela hipótese de que há um sentido de origem social do assentamento instituído numa base comum de luta expressa pelo ser-assentado, mas que carrega em si significâncias para além da significação que a expressão luta pela terra sugere abarcar. Contudo, o viés de ligação destes assentados a terra se dá pela forma principal do torneamento da rocha esteatito (pedra-sabão), que aflora no local para a confecção artesanal de panelas. O tornear, para além de estabelecer vínculo, se traduz em uma dimensão do saberfazer que dá sentido de "lugar" a esta terra. Porquanto, as terras do Cafundão se inserem numa dinâmica de conflitos acerca de sua real posse, que envolve as vidas já estabelecidas nestas terras por aqueles que recorreram à política de reforma agrária enquanto possibilidade de resolução do impasse, a posse jurídica concedida à Igreja (católica) e a tentativa de compra e venda por um terceiro que criou o ápice da tensão ao requerer a sua desapropriação.

Palavras-chave: sociogênese de assentamento; ruralidade; memória e território; Cafundão, MG. 


\begin{abstract}
This dissertation brings the issue of the Brazilian lands, regarding to the land inequality history that among other approaches promotes the social movements, the struggle for land access and the claim for agrarian reform policies as an institutionalized path for this access. The research dedicated itself to the memories of settlers who make up and reveal the sociogenesis in an specific settlement for agrarian reform which is Cafundão, located in Mariana, a historic town of Minas Gerais state.

The research was conducted by the settler's narratives in dialogue with documents and theoretical reflections that contribute to the analysis in this context. We started from the idea that Cafundão settlement is part of a broader land context that gives it substance and meaning and accepted as questioning the narratives that the settlers tell about the history of struggles for land which originated that settlement. We were guided by the hypothesis that there is a sense of social origin of the settlement established on a common basis of struggle expressed by the seated-being, but it carries with it a significance beyond the meaning that the term "struggle for land" suggests to be over.

However, the connection biases of these settlers to the land is given by the main way of turning the steatite rock (soapstone), which outcrops on the site for artisanal cooking pots. The sculpting, besides setting ties, translates itself into a dimension of know-how that gives sense of "place" to this land. For a while, the land of Cafundão is part of a conflic dynamic about its actual possession, that involves the lives already established in these lands by those who appeled to an agrarian reform policy as a possibility of resolving the impasse, the legal ownership granted to the Church (Catholic) and the attempted to purchase and sell by a third actor who created the tension's peak by requesting its expropriation.
\end{abstract}

Keywords: sociogenesis settlement; rurality; memory and territory; Cafundão, MG. 


\section{LISTA DE SIGLAS E ABREVIATURAS}

ANL

ANP

APL

ARENA

ATER

BR

$\mathrm{CCV}$

CEB

CETEC

CLT

CNBB

$\mathrm{CNJ}$

$\mathrm{CNV}$

CONTAG

CPI

CPT

DATALUTA

DNPM

DOU

DRP

EMATER

EMATER-MG

EMATER

MARIANA

EMBRAPA

ETR

FAEMG

FETAEMG
Aliança Nacional Libertadora

Agência Nacional de Petróleo

Arranjo Produtivo Local

Aliança Renovadora Nacional

Lei de Assistência Técnica e Extensão Rural

Batalhão Rodoviário

Comissão Camponesa da Verdade

Comunidade Eclesial de Base

Fundação Centro Tecnológico de Minas Gerais

Consolidação das Leis de Trabalho

Conferência Nacional de Bispos do Brasil

Conselho Nacional de Justiça

Comissão Nacional da Verdade

Confederação Nacional dos Trabalhadores na Agricultura.

Comissão Parlamentar de Inquérito

Comissão Pastoral da Terra

Dados da Luta pela Terra

Departamento Nacional de Pesquisa Mineral

Diário Oficial da União

Diagnóstico Rural Participativo

Empresa de Assistência Técnica e Extensão Rural

Empresa de Assistência Técnica e Extensão Rural de Minas Gerais

Empresa de Assistência Técnica e Extensão Rural, seção Minas, escritório local Mariana.

Empresa Brasileira de Pesquisa Agropecuária

Estatuto do Trabalhador Rural

Federação da Agricultura e Pecuária do Estado de Minas Gerais

Federação dos Trabalhadores na Agricultura no Estado de Minas Gerais 
FHC

FUNRURAL

IBGE

IBRA

INCRA

INDA

ITR

LULA

MAB

MAPA

MDA

MDB

MF

MG

MIRAD

MST

NEAD

NERA

PA

PA CAFUNDÃO

PAF

PCB

PCBR

PCdoB

PCR

PC-SBIC

PDC

PDS

PNRA

PopLin

PND
Fernando Henrique Cardoso

Fundo de Assistência e Previdência do Trabalhador Rural

Instituto Brasileiro de Geografia e Estatística

Instituto Brasileiro de Reforma Agrária

Instituto Nacional de Colonização e Reforma Agrária

Instituto Nacional de Desenvolvimento Rural

Imposto sobre Propriedade Territorial Rural

Luiz Inácio Lula da Silva

Movimento dos Atingidos por Barragem

Ministério da Agricultura, Pecuária e Abastecimento

Ministério do Desenvolvimento Agrário

Movimento Democrático Brasileiro

Módulo Fiscal

Minas Gerais

Ministério da Reforma e do Desenvolvimento Agrário

Movimento dos Sem-Terra

Núcleo de Estudos Agrários e Desenvolvimento Rural

Núcleo de Estudos, Pesquisas e Projetos de Reforma Agrária

Projeto de Assentamento

Projeto de Assentamento Cafundão

Projeto de Assentamento Agroflorestal

Partido Comunista do Brasil / Partido Comunista Brasileiro

Partido Comunista Brasileiro Revolucionário

Partido Comunista do Brasil

Partido Comunista Revolucionário

Partido Comunista - Seção Brasileira da Internacional Comunista

Partido Democrata Cristão

Projeto de Desenvolvimento Sustentável

Plano Nacional de Reforma Agrária

População nas Listas Nominativas de Minas Gerais

Plano Nacional de Desenvolvimento 
PRC

PR Federal

PRF

PRM

PRP

PRONERA

PRT

PSC

PSD

PT

PTB

RPT

SIPRA

SR

SUPRA

TDA

TFP

UDN

UDR

$\mathrm{UnB}$

UNE

VPR
Partido Republicano Conservador

Partido Republicano Federal

Partido Republicano Fluminense

Partido Republicano Mineiro

Partido Republicano Paulista

Programa Nacional de Educação na Reforma Agrária

Partido Revolucionário dos Trabalhadores

Partido Social Cristão

Partido Social Democrático

Partido dos Trabalhadores

Partido Trabalhista Brasileiro

Registro Paroquial de Terras

Sistema Institucional do Programa de Reforma Agrária

Superintendência Regional

Superintendência de Política de Reforma Agrária

Títulos de Dívida Agrária

Movimento Tradição, Família e Propriedade

União Democrática Nacional

União Democrática Ruralista

Universidade de Brasília

União Nacional dos Estudantes

Vanguarda Popular Revolucionária 


\section{LISTA DE FIGURAS}

Figura 1 Trevo de entrada para o distrito Cachoeira do Brumado (Mariana-MG). Acervo de pesquisa (2013).

Figura 2 Estrada de acesso ao centro do distrito Cachoeira do Brumado (Mariana-MG). Acervo de pesquisa (2013).

Figura 3 Visão, ao fundo, da cachoeira que dá nome ao distrito: Cachoeira do Brumado. Foto tirada no acesso ao Cafundão de Baixo. Acervo de pesquisa (2013).

Figura 4 Senhor Adão mostrando os moinhos usados no Cafundão de Baixo. Como estavam trancados, tirou-se fotografias do lado externo e, ao burlar a cerca, do lado interno do moinho. Lado externo da casa do moinho. Acervo de pesquisa (2013).

Figura 5 Lado interno do moinho situado no Cafundão de Baixo. Acervo de pesquisa (2013).

Figura 6 Rotatória que marca o limite do percurso do ônibus, que faz o trecho sede de Mariana ao distrito de Cachoeira do Brumado. Observa-se que há a presença de asfalto. Acervo de pesquisa (2013).

Figura 7 Estrada de acesso ao assentamento Cafundão, passando por loteamentos, plantação de eucalipto, e casas maiores em relação à maioria daquelas de todo o distrito. Acervo de pesquisa (2013).

Figura 8 Placa de entrada ao loteamento Bela Ville, localizado no topo da vertente onde o assentamento se localiza. Acervo de pesquisa (2014).

Figura 9 Imagem do loteamento Bela Ville. Acervo de pesquisa (2014).

Figura 10 Exemplificação de moradia construída no loteamento Bela Ville. Acervo de pesquisa (2014).

Figura 11 Exemplo de casa construída com telhado evidenciado, estilo europeu em formato triangular. Acervo de pesquisa (2014).

Figura 12 Visão do cômodo usado como local onde se armazena, em sua parte externa, os blocos de esteatito a serem torneados para confecção de panelas. Acervo de pesquisa (2013).

Figura 13 Visão interna do espaço coletivo, sem telhado, janelas, portas, e com a vegetação adentrando. Acervo de pesquisa (2014).

Figura 14 Senhor Nilton na confecção de panela, no interior do galpão. Acervo de pesquisa (2013). 
Figura 15 À esquerda, Dona Sandra na III Feira da Agricultura Familiar do Estado de Minas Gerais - Agriminas. Nesta ocasião, o INCRA-MG promoveu a exposição de produtos diversos oriundos de assentamentos de reforma agrária, e o Projeto de Assentamento (PA) Cafundão fora um deles.

Figura 16 Roda de um moinho manual já desativado. Foi apresentado como primeiro moinho que o senhor Adão possui lembrança. Acervo de pesquisa (2013).

Figura 17 Casa do moinho. Acervo de pesquisa (2013).

Figura 18 Pinguela sobre o córrego que movimenta o moinho, na confecção de farinha de milho. Acervo de pesquisa (2013).

Figura 19 Senhor Adão, na porta de entrada da casa do moinho. Acervo de pesquisa (2013).

Figura 20 Visão da parte da frente, e externa, do galpão com os blocos ao torneamento. À direita, a estrada de acesso ao assentamento, com lotes com plantação de eucalipto. E à esquerda, íngreme em direção ao córrego, a área do assentamento. Acervo de pesquisa (2013).

Figura 21 Capitanias Hereditárias.

Figura 22 Nova disposição das Capitanias Hereditárias.

Figura 23 Travessia com o senhor Adão, que sentou-se no banco do passageiro e apontava o que se queria mostrar. Acervo de pesquisa (2014).

Figura 24 Lar da família do senhor Nilton e da dona Sandra. Acervo de pesquisa (2014).

Figura 25 Lar da senhora que ofereceu um copo d'água por que o sol estava muito quente. Ela ainda sofre, cotidianamente, a violência psicológica pela terra do Cafundão. Acervo de pesquisa (2014).

Figura 26 Senhor que fora baleado na ocasião da violência pela terra do Cafundão. Acervo de pesquisa (2014).

Figura 27 Reunião dos trabalhadores da Cooperativa ao lado do galpão no pós-almoço. No canto esquerdo, trata-se do pai da pesquisadora, que a acompanhou durante vários trabalhos de campo ao assentamento. Ao seu lado, senhor Adão. Sentado ao centro, com camisa laranja, o senhor Nilton. Os três jovens são sobrinhosnetos do senhor Adão, filhos de seus irmãos, alguns já falecidos. Acervo de pesquisa (2014).

Figura 28 Local onde será construída a casa da filha do senhor Adão, no interior do seu lote do assentamento PA Cafundão. Acervo de pesquisa (2014).

Figura 29 Visão ortogonal da área que corresponde à Fazenda Cafundão (que engloba o assentamento, com dados obtidos da Travessia de pesquisa) e do Projeto de Assentamento Cafundão (INCRA, 2010). 
Figura 30 Igreja Assembleia de Deus frequentada pelos assentados do Cafundão. Esta igreja se localiza no Cafundão de Baixo, o que nutre a querência pela construção de igreja própria no espaço - cômodo em construção - destinado ao uso comum. Acervo de pesquisa (2015).

Figura 31 Filha do senhor Nilton e da dona Sandra, chamada Patrícia, que ingressou em curso superior de pedagogia do campo na Universidade Federal de Minas Gerais. Acervo de pesquisa (2010).

Figura 32 Cafundão, uma história de vida. Narrativa da luta dos assentados pela terra do Cafundão, construída em uma lauda de folha de caderno que está colada na parede da Cooperativa enquanto apresentação ao visitante. Acervo de pesquisa (2013).

Figura 33 Transcriação da narrativa de luta dos assentados do Cafundão.

Figura 34 Senhor Nilton, com o banner da pesquisa, e seus três sobrinhos que trabalham na Cooperativa de Pedra, e esperavam juntos o atravessador para vender as panelas, num domingo no mês de setembro. Ao fundo, a Cooperativa. Acervo de pesquisa (2014).

Figura 35 Fotografia do senhor Nilton lendo o banner construído nesta pesquisa como parte da primeira devolutiva.

Figura 36 Fotocópia do banner entregue aos assentados do cafundão em setembro de 2014.

Figura 37 Senhor Adão aponta o que se quer que saiba. Acervo de pesquisa (2014).

Figura 38 Senhor Adão em Travessia de pesquisa, percorrendo o interior dos lotes do assentamento. Acervo de pesquisa (2014).

Figura 39 Senhor Adão aponta onde se localizava a casa de seu pai, Francisco da Cruz de Oliveira, em área próxima ao córrego da Pinduca, onde ainda existe o moinho d'água conforme Figura 12. Acervo de pesquisa (2014).

Figura 40 Senhor Adão reforçando que ele se orienta através da cerca. Percebeu-se que se tratar de onde ela está ou esteve um dia. Acervo de pesquisa (2014).

Figura 41 Senhor Adão abrindo-se à pesquisa. Acervo de pesquisa (2014).

Figura 42 Pesquisadora com o senhor Adão em frente ao Galpão da Cooperativa. Acervo de pesquisa (2014).

Figura 43 Senhor Adão mostrando as panelas já prontas com o cobre. Ao fundo, as panelas comuns. No canto direito, a inovação que fizeram na confecção de panelas de pressão, por meio de curso da EMATER - Mariana. Acervo de pesquisa (2014).

Figura 44 Blocos de esteatito em vias de torneamento no interior do galpão. Acervo de pesquisa (2014). 
Figura 45 Neto do senhor Adão que brinca no pó da pedra antes dela servir para nutrir hortas. Acervo de pesquisa (2014).

Figura 46 Torno usado da Cooperativa dos assentados. Acervo de pesquisa (2014).

Figura 47 Torno hidráulico que pertence à cooperativa. Está subutilizado, restrito à produção de tampas de panela.

Figura 48 Senhores Adão e Nilton explicam o uso medicinal de planta encontrada pelo pai da pesquisadora, que é uma espécie de pteridófita que seria bom para a recuperação do fígado. Acervo de pesquisa (2014).

Figura 49 Cooperativa de panelas de pedra dos assentados do Cafundão. Acervo de pesquisa (2014).

Figura 50 Assentado que fora baleado no episódio de luta pela terra do Cafundão, com sua foice que é uma ferramenta agrícola. Acervo de pesquisa (2014).

Figura 51 Placa colocada na entrada da Fazenda Cafundão. Há alguns metros dali, o senhor Adão considera que começa o assentamento, a despeito de este ponto já pertencêlo, conforme INCRA (2014). Acervo de pesquisa (2014)

Figura 52 Cerca, à esquerda, que marca para o senhor Adão o início do assentamento Cafundão. Acervo de pesquisa (2014). 


\section{LISTA DE MAPAS}

Mapa 1 Localização do Projeto de Assentamento Cafundão (Mariana, Minas Gerais, Brasil).

Mapa 2 Delimitação do Projeto de Assentamento Cafundão no interior da Fazenda Cafundão.

Mapa 3 Localização do Distrito de Cachoeira do Brumado em Mariana (Google Earth, 2015) com destaques temáticos para a sobreposição de terras do imaginário da Fazenda Cafundão e o que pertenceu ao senhor M.

Mapa 4 Localização dos Projetos de Assentamento no estado de Minas Gerais, segundo INCRA (2014).

Mapa 5 Mapa dos lotes do Projeto de Assentamento Cafundão, elaborado pelo INCRA (1994).

Mapa 6 Localização do PA Cafundão em terras circundadas pela atividade mineradora. 


\section{LISTA DE TABELAS}

Tabela 1 Evolução dos assentamentos de reforma agrária no Brasil, originados por ações do Governo Federal.

Tabela 2 Números de projetos de assentamentos criados entre o período de 1994 a 2002, conforme SIPRA.

Tabela 3 Número de projetos de assentamentos criados entre o período de 2004 a 2012, de acordo com DATALUTA.

Tabela 4 Classificação de tamanho de imóveis rurais nos municípios de Mariana-MG, Belo Horizonte e Buritizeiro, com base nos módulos fiscais destes municípios.

Tabela 5 Reprodução ampliada da tabela contida no mapa anterior (INCRA, 1994). 


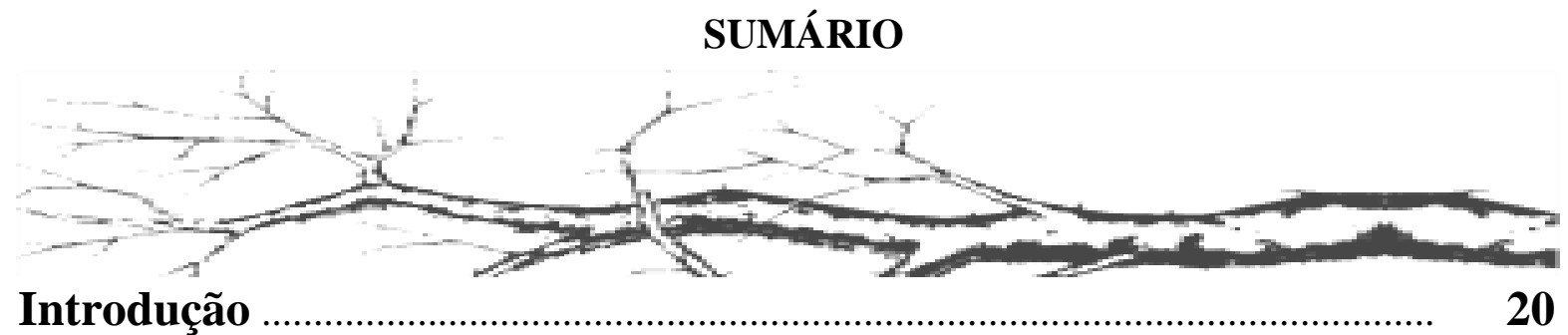

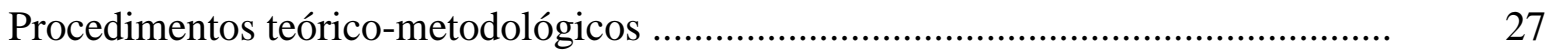

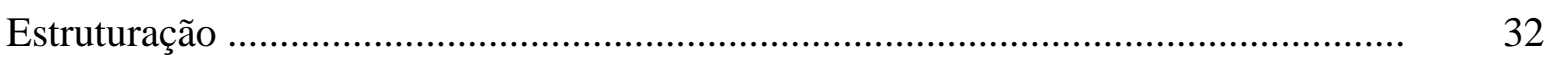

1. Agrária e agrícola em uma questão brasileira 34

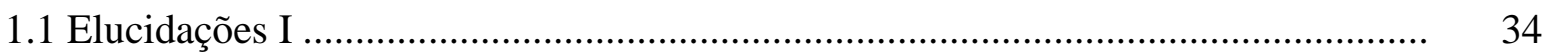

1.2 Os confrontos no Cafundão: Lugar de guerra mesmo ........................................... 50

1.3 A historicidade da desigualdade de terras no Brasil ............................................. 67

2. A política de reforma agrária e o cenário fundiário brasileiro 75

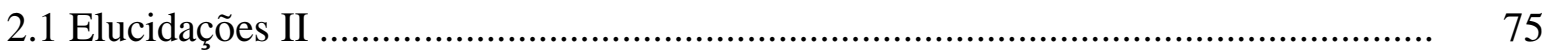

2.2 Alguns aspectos da jurisprudência agrária brasileira............................................... 88

2.3 Reforma agrária: construção e atribuição de significados......................................... 105

2.4 A política brasileira de Reforma Agrária: diretrizes gerais.................................... 117

3. Sociogênese do assentamento: a reivindicação da reforma agrária 139 dos assentados do Cafundão (Mariana-MG)

3.1 Elucidações III

3.2 Exemplificações da criminalização da luta pela terra: a Igreja, o Estado Ditatorial e a emergência do MST.

3.3 As terras do Cafundão enquanto memória e herança.............................................. 160

$3.4 \mathrm{O}$ acampar como forma de fazer-se visto......................................................... 190

3.5 As significâncias do ser-assentado e o fazer-panela na terra.................................... 198

4. À guisa de uma conclusão: memórias e identidades territoriais 209

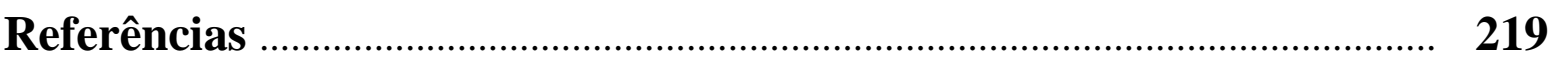




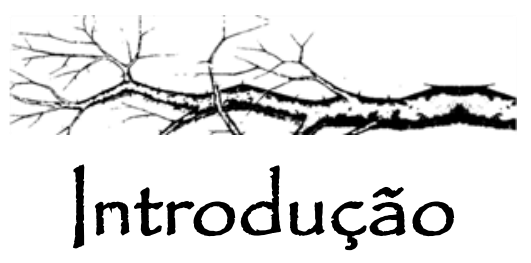

"Eternidade: pois tudo o que é nunca começou. Mínha pequena cabeça tão límítada estala ao pensar em alguma coísa que não começa e não termína - porque assím é o eterno. Felizmente esse sentímento dura pouco porque eu não aguento que demore e se permanecesse levaría ao desvario. Mas a cabeça também estala ao imaginar o contrário: alguma coísa que tivesse começado - poís onde começaria? E que termínasse - mas o que viría depoís de terminar? Como vês, é-me impossivel aprofundar e apossarme da vida, ela é aérea, é o meu leve hálito. Mas bem seí o que quero aquí: quero o ínconcluso. Quero a profunda desordem orgânica que, no entanto, dá a pressentír uma ordem subjacente" (Clarice Lispector).

É preciso saber ultrapassar o desafio de se começar algo. Na escrita, principalmente. As frases dispostas de forma inicial nem sempre são escritas primeiro, ao mesmo tempo em que não se pretende que elas indiquem um começo. Isto - de se tentar começar - se configurou num desafio de pesquisa: o caminho metodológico dá sugestões de como se deveria organizar a própria composição dos capítulos, de forma a sugerir também que eles estejam amarrados, dependentes, coconstruídos e coconstituintes. Mas sobre o como começar, ainda não há manuais que descortine esta tarefa.

Perante o desafio de se começar, pensou-se em dois mecanismos: o primeiro deles haveria de considerar a periodização. Isto porque, começar algo guarda em si uma ideia de marco zero, ponto inicial. O ponto inicial não haveria de sobrepor tudo aquilo que lhe antecede, que lhe é anterior e que lhe foi destituído ao começo, para além da pretensão de significar ser realmente o começo. Neste sentido, o início aqui emerge enquanto escolha, dentre vastas e outras possibilidades. Escolheu-se a periodização, sobre a qual irá ainda se explanar. 
O segundo mecanismo diria respeito à demonstração de como se deu esse processo de escolha e todos os outros que fundamentaram o desenvolvimento desta pesquisa. Para tanto, criou-se os momentos denominados Elucidações, que estão presentes no início de cada capítulo. Nas Elucidações estarão expostas as escolhas de cunho teórico-metodológico, bem como tentou-se aproximar o leitor da própria pesquisa e de demarcar o Eu enquanto sujeito que pesquisa um Outro, para além da pretensão de ser a voz do Outro. Tentou-se instituir, destarte, uma fronteira Eu-Outro através do elucidar, com base na possibilidade de escrever sobre o Outro: de escrever, de-escrever, descrever.

Faz-se necessário justificar brevemente, portanto, que o começo desta textualização talvez seja justamente o conflito com a ideia de apresentar um começo. Ao mesmo tempo, em que se almeja aproximar-se de quem lê a fim de apresentar todo o processo de desenvolvimento, amadurecimento e aberturas suscitadas por esta pesquisa.

Este texto introdutório seria, pois, as primeiras Elucidações desta Dissertação: a explicação de que se começa a dialogar sobre uma pesquisa que, a despeito dos avanços, ainda ronde os terrenos instigantes do inconcluso.

E se começou a investigar (...).

A presente Dissertação de Mestrado se relaciona à questão de terras brasileiras, no que concerne ao histórico de desigualdade fundiária que fomenta, dentre outros enfoques que poderiam ser destacados, a luta e os movimentos sociais pelo acesso a terra, e a reivindicação da política de reforma agrária enquanto via institucionalizada de promoção deste acesso. Dedica-se, nesta pesquisa, às memórias dos assentados que compõem e revelam o contexto social de um assentamento de reforma agrária específico que é o Cafundão, localizado em Mariana, cidade histórica de Minas Gerais. Em outras palavras, parte-se da ideia de que o assentamento de reforma agrária Cafundão integra o contexto de terras mais amplo que lhe dá substância e sentido, e admite-se enquanto inquirição as narrativas que os assentados fazem da história de luta pela terra que deu origem a esse assentamento de reforma agrária. Bem como, há o inquérito de tensões inerentes à formação da memória coletiva da luta que fomenta representações acerca dos próprios atores que pertenceram de alguma forma a este cenário. 
Explica-se que o olhar se voltou ao assentamento Cafundão na ocasião de uma visita de campo em meados do ano de 2010, durante a graduação em Geografia. Mas, o olhar sobre ele já estava sendo construído, a despeito de ainda não conhecê-lo. Como assentamento de reforma agrária, ele guarda em si imagens e paisagens muitas vezes oriundas daquelas criadas em relação à expressão reforma agrária. Salienta-se que a definição de reforma agrária é dada pela Lei 601 do ano 1850 em seu parágrafo 1, artigo primeiro, sendo utilizada ainda hoje pelos órgãos governamentais: "reforma agrária é o conjunto de medidas para promover a melhor distribuição da terra, mediante modificações no regime de posse e uso, a fim de atender aos princípios de justiça social, desenvolvimento rural sustentável e aumento de produção".

Mapa 1: Localização do Projeto de Assentamento Cafundão (Mariana, Minas Gerais, Brasil).

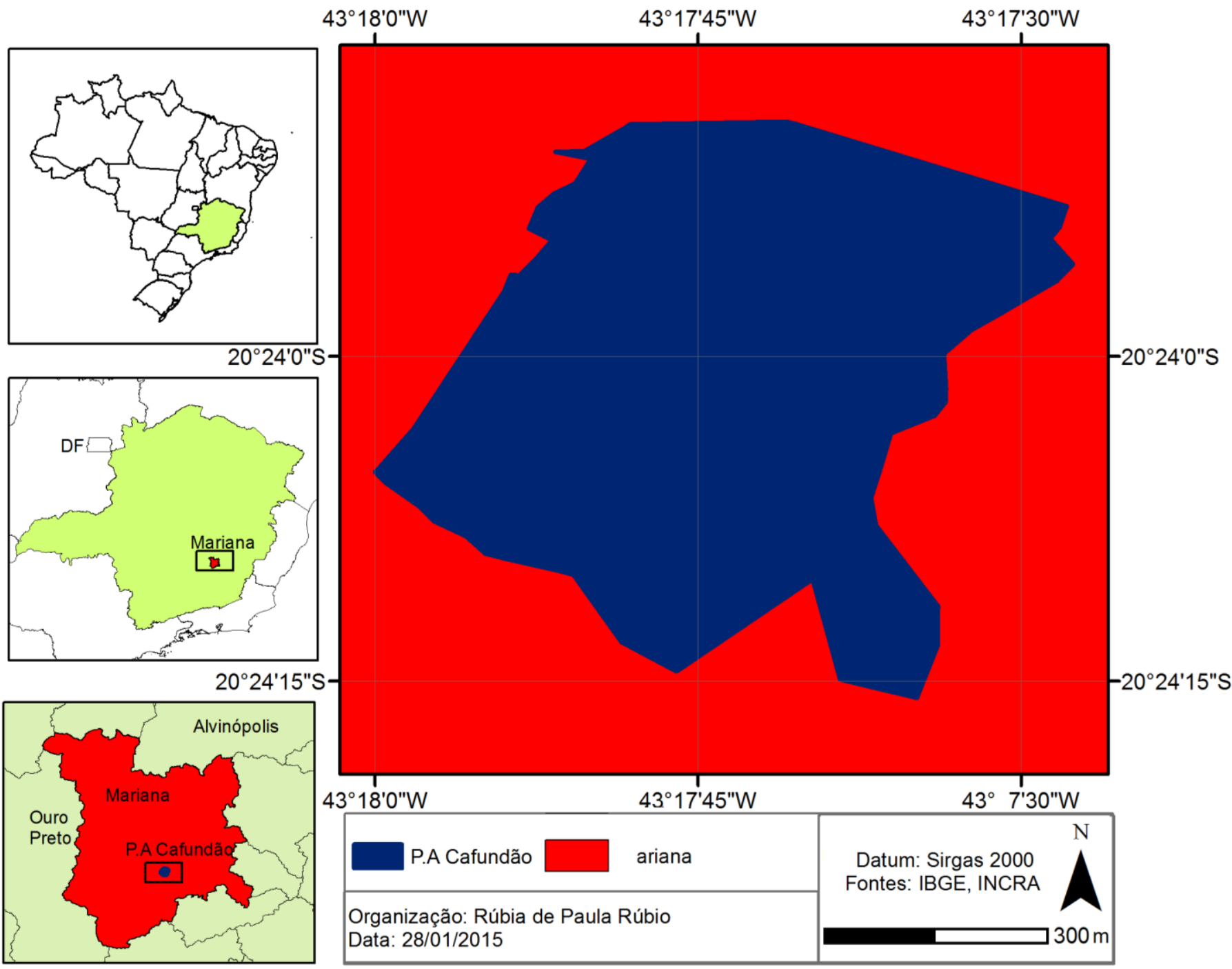


Esse assentamento foi resultado de uma luta pela terra que, aqueles que são hoje assentados, já consideravam como suas. Uma luta por uma terra que já era também lugar. Localizado no distrito Cachoeira do Brumado, no município de Mariana-MG, com quarenta e oito hectares e composto por doze famílias, as terras do Projeto de Assentamento Cafundão também fizeram parte dos tensionamentos inerentes à construção do espaço marianense, que se esbarra em questões - religiosas, econômicas, políticas... - que estão para além do próprio assentamento.

Resultante direto de uma política geral de assentamento de reforma agrária, e considerado consolidado pelos indicadores governamentais, o Cafundão oferece subsídios para se pensar na maneira como tais políticas se expressam nos lugares e, nesse caso, no contorno que ela assumiu perante a importância dessas terras para essas pessoas, que nela sempre viveram, trabalharam, e imprimiram seus códigos culturais; e por isso, já era lugar antes de ser assentamento. Irá se perceber, inclusive, como o aspecto produtivo da terra tivera que ser reformulado aos assentados do Cafundão através do incentivo à produção artesanal com a pedra-sabão ou esteatito. O saber-fazer panela de pedra emerge enquanto eixo de ligação íntima com a terra.

Portanto, a luta pela terra absorveu essencialmente a importância que tal terra possui para esse grupo, que nela já vivia há gerações. Fez emergir uma consciência política capaz de institucionaliza-la a partir da petição de se tornar assentamento de reforma agrária, assim como criou sentidos e representações que carecem de aprofundamentos e estão estritamente ligados à formação da memória e da identidade coletiva de luta que se correlacionam às memórias e às identidades dos assentados. Porquanto, se atentará à investigação das memórias que o Outro possui de sua luta pela terra em diálogo com as fontes documentais na tentativa de apreender o histórico de criação do assentamento Cafundão. O Outro, que são os assentados, se une numa coletividade advinda de um sentido criado no lutar juntos por uma terra.

Neste sentido, enquanto Objetivo Geral de pesquisa, almejou-se investigar a sociogênese do assentamento Cafundão, localizado no bairro Cafundão, do distrito Cachoeira do Brumado, do município de Mariana do estado de Minas Gerais. Essa investigação foi realizada a partir da apreensão de narrativas que os assentados fazem da história de luta pela terra que deu origem a esse assentamento, da pesquisação em torno da construção da memória 
coletiva de luta, e do inquérito de documentações que retratem a tensão inerente ao processo de petição da política de reforma agrária.

Quatro foram os desdobramentos ou inquietações que se alinham a esse Objetivo Geral, quais sejam: i. Situar o assentamento de reforma agrária Cafundão como pertencente ao contexto da reprodução do espaço agrário-agrícola brasileiro; ii. Analisar o movimento histórico da reprodução do espaço tendo-se em vista diferentes escalas de contextos que dão origem ao assentamento - assumindo aqui a escala como estratégias de aproximação, destacando-se Brasil, Estado de Minas Gerais, cidade de Mariana, distrito Cachoeira do Brumado, bairro Cafundão, terras do assentamento, lote das famílias dos assentados; e dinâmicas familiares; iii. Investigar as narrativas que os assentados do Cafundão fazem de sua própria luta pela terra, através do inquérito de aspectos ligados à tensão na formação da memória coletiva da luta e das identidades territoriais, e suas relações para com a origem social desse assentamento; iv. Inquirir sobre territorializações de memória na apreensão, apropriação e reprodução de espaço.

A delimitação espaço-temporal desta investigação se relaciona, evidentemente, às próprias memórias da luta pela terra do Cafundão (Mariana-MG) que atuam enquanto eixo de periodização. Não se escolheu estritamente o começo da história de luta pela terra do Cafundão, por que trata-se de algo difuso, inapreensível. Um começo teria que ser admitido somente como marco simbólico de início de luta. É preciso ressaltar, com isso, que luta aqui não diria respeito a um evento, com início e fim, e sim abarcaria todos os processos, motivações e tensões que atuam como elementos pertencentes a um eixo temático enfocado, que aqui é a luta pela terra do Cafundão. Em outras palavras, inclui processos sociais mais amplos que lhe deram substância e sentido, mas não teve seu final com a efetivação da política de reforma agrária, em consonância com Eloy Alves Filho et al (2011) para quem a luta não se esgota na terra: são tensões na/da terra, e ela continua na tentativa de nela permanecer e dela sobreviver.

Por conseguinte, por essa investigação acerca da história de luta pela terra dos assentados do Cafundão se dar por meio teórico-metodológico da memória, nela estará inclusa processos de remembramento, silenciamento, recriação do vivido, tensões entre os espaçostempos de acontecimento. Assim como a investigação sobre a história de luta pela terra do Cafundão, por se dar através das memórias dos assentados, inclui processos que diz respeito às rememorações, recriações, tensões e versões de tal luta. A história aqui foi assumida em 
sua versão plural, polifônica e tensa. Essas particularidades também contribuem para que a demarcação da luta pela terra seja imprecisa no sentido cronológico de se tentar datá-la. Por conta disso, perguntas que sugerem investigar um começo da luta (quando?) requerem que se debruce sobre as memórias que se tem e sobre as identidades delas emergidas ou por elas criadas.

A luta pela terra, portanto, ainda se faz presente no cotidiano e se recria através de representações e de rememorações, e é sobre essas tais que se investiu o olhar, o ouvir e o escrever dessa pesquisa, em conformidade com as orientações de Geertz (1989). Buscou-se por rememorações da luta, apreendendo as narrativas que os assentados fazem dela, considerando as tensões existentes na criação das memórias coletivas da luta e nas identidades do ser-assentado. Tais rememorações sugerem o contexto social, concernente ao conflito da ocupação da terra em detrimento de sua propriedade jurídica, que invocou a luta pela criação do assentamento enquanto via institucional de resolver tensões.

Além disso, optou-se por realizar este recorte espaço-tempo para além da delimitação física a partir da jurisdição que cria os quarenta e oito hectares que compõe o assentamento. Isto por que tal história extrapola estes limites impostos à efetivação da política pública de reforma agrária. Assim, dedica-se às memórias de luta pelo Cafundão daqueles que são hoje assentados, através do reconhecimento da importância etnográfica de pesquisa que considera, inclusive, as terras do assentamento enquanto incentivo de memória. Como se verá, o mecanismo teórico-metodológico da Travessia (VERDEJO, 2006) contribuiu para ultrapassar a delimitação física do assentamento e a recompor a memória de toda a Fazenda Cafundão, que é no interior deste onde o assentamento está localizado.

Por este motivo, são tais memórias da luta pela terra do Cafundão que emergem enquanto recorte de pesquisa. Estas memórias são oriundas e também são criadas por um panorama maior que abrange não somente um histórico de movimentos sociais pelo acesso a terra, mas também à própria historicidade da construção do espaço brasileiro. Entende-se que as memórias dos assentados se tornam uma concretude de análise que está para além de serem meros beneficiários de política pública de criação de assentamento e, por isso, investiga-se através delas a origem social do assentamento.

Ressalta-se que é pretendido contribuir para que o histórico de luta pela terra do Cafundão deixe de se resumir a ser somente exemplo em textos acadêmicos num comparativo com outros em Minas Gerais, atrelado à consideração de ser encarado enquanto resultado de 
política de reforma agrária. Isto por que o conhecimento da luta pela terra que culminou no assentamento se revelou, ao longo da monografia de conclusão de curso de geografia realizada ${ }^{1}$, restrito a poucas pessoas que se relacionaram de alguma forma com essa luta e foi registrado por poucos autores, tais como Alves Filho et al (2007; 2008; 2009), Agência Brasil (2002a, 2002b), MDA (2008), CETEC-MG (2006), Silva et al (2006). Não foram encontrados escritos bibliográficos sobre o Cafundão, e aqueles poucos encontrados que o mencionam em poucas linhas concebem esse assentamento como objeto de comparação com outros situados em Minas Gerais. É percebido, pois, que esse assentamento tem composto tão somente os quadros e tabelas comparativas de indicadores sociais ou de análises socioeconômicas de assentamentos de reforma agrária. Tais estudos não são subestimados, por que é inegável a validade e a importância destes. Porém, ratifica-se a necessidade de se conhecer o Cafundão para além de seu aspecto comparativo: esse assentamento foi resultado de contextos peculiares e é preciso captá-los e, assim, compará-los ou discuti-los, tendo em vista outros particulares históricos de luta pela terra. Esse foi um dos esforços da presente Dissertação.

Dessa maneira, o problema que norteia este estudo é: quais elementos, apreendidos através da memória pertencem à origem social do assentamento de reforma agrária Cafundão? Partiu-se da hipótese de que há um sentido de origem social do assentamento instituído numa base comum de luta expressa pelo ser-assentado, mas que carrega em si significâncias para além da significação que a expressão luta pela terra sugere abarcar. Em outras palavras, os elementos apreendidos na pesquisa como pertencentes à origem social do assentamento deverse-iam convergir ao panorama de desigualdade fundiária que marca a construção do espaço brasileiro, mas passar-se-ia também pelo crivo da apropriação local desta historicidade.

A busca por memórias e identidades ligadas a criação do assentamento Cafundão enveredou-se neste sentido de tentar absorver concretudes não manifestadas somente com o entendimento da política de assentamento como um mitigador de um processo mais amplo. Há de se entender, ou melhor, apreender versões locais para o chamamento ou aplicação de uma política, dando sentido de se inquirir por memórias e identidades que expressem sentidos, concretudes e apropriações.

\footnotetext{
${ }^{11}$ RÚBIO, Rúbia de Paula. Em busca de sombras que não obscurecem uma luta: narrativas de vidas espaciais dos assentados e assentamento Cafundão, Mariana-MG. Licenciatura em Geografia. Instituto Federal de Educação, Ciência e Tecnologia de Minas Gerais - Campus Ouro Preto, novembro de 2012.
} 
Considerou-se nesta pesquisa, e de forma a interferir nas versões de luta pela terra, a tensão política entre órgãos e atores e suas diferentes escalas (do município, do estado e da esfera federal de governo), o atravessamento de poderes e de imaginários que fomentam um sentido de adquirir ou possuir legitimidade no acesso e na posse da terra, bem como, ratificase o Eu que intervém enquanto aquele que apreende narrativas de um escopo cultural próprio, que constrói e suscita análises. Sendo assim, apresenta-se aqui a pesquisa que se enveredou pela investigação da formação, construção, conformação e invenção de memórias e de identidades coletivas dos assentados do Cafundão no que concerne às narrativas que possuem de sua própria luta, utilizando-se de orientações teórico-metodológicas com inclinações etnográficas.

\section{Procedimentos Teórico-Metodológicos}

É preciso enfatizar que o tema dessa pesquisa, que diz respeito à investigação da origem social do assentamento Cafundão (Mariana-MG), se relaciona ao cenário de desigualdade fundiária que marca a construção do espaço brasileiro, consubstanciando as análises do que se chama de Geografia Agrária - a despeito de breves considerações que serão feitas a este campo disciplinar geográfico. Por se debruçar sobre a investigação de memórias e de identidades dos assentados no que concerne a essa história de luta pela terra, esbarra-se em investigações que se arrolam à chamada Geografia Humanista e sua inclinação fenomenológica, e antropológica de análise. Neste sentido, alguns conceitos revelaram-se fundamentais ao desenvolvimento e espacialização desta pesquisa, quais sejam: território, memória, identidade, política de assentamento e sociogênese - que serão devidamente emaranhados no decorrer da textualização.

Adianta-se ser imperativo considerar que os processos formadores de memórias e de identidades em suas extensões coletivas absorvem as especificidades e complexidades que são inerentes e que norteiam a noção de sociogênese na análise de fenômenos sociais específicos, que nesse caso é a luta pelo assentamento Cafundão. De outra forma, a investigação das memórias e das identidades revelam características do contexto espacial e, pois, da sociogênese que invocou a luta pela criação do assentamento de reforma agrária.

Porquanto, o caminho metodológico da Dissertação assenta-se sobre as narrativas que 
são o modo discursivo de apreensão de expressões espaciais e de histórias de vidas (LINDÓN, 2008) estritamente ligadas à construção de espaço. Esta relação também é denominada por Patrício Sousa (2011) como biografia espacial. Por conta disso, se realizou uma revisão de literatura a respeito da formação de memória e de identidade coletivas, bem como sobre suas correlações e interdependências para com a construção de espaço e de espacialidade.

Quanto às metodologias de campo, lançou-se mão de observação participante, de entrevistas semi-estruturadas e do uso da Caminhada Transversal contido no Diagnóstico Rápido Participativo, o que aqui se assume enquanto Travessia (VERDEJO, 2006).

A observação participante se deu em consonância com as orientações teóricometodológicas de Clifford Geertz (1989), que ressalta a importância de se realizar descrições do cotidiano e da dinâmica interna de um grupo a ser estudado. Este autor ainda destaca a importância de se manter um Diário de Campo como forma de registro de impressões.

Essa forma de registro no Diário se configura em etapa crucial do trabalho, na medida em que concentra as narrativas que foram apreendidas - olhadas e ouvidas - no campo e que são interpretadas no momento da textualização ou do escrever da pesquisa, seguindo-se as orientações de Oliveira (1996). Entende-se que "o passado espelhado no presente reproduz, através de narrativas, a dinâmica da vida pessoal em conexão com processos coletivos”. Isto por que, "a reconstituição dessa dinâmica, pelo processo de recordação, que inclui ênfases, lapsos, esquecimentos, omissões, contribui para a reconstituição do que passou segundo o olhar de cada depoente" (DELGADO, 2006, s.n.t). Dessa forma, o Diário se traduz num caderno onde se as percepções oriundas de cada conversa, de cada olhar, de cada situação que conseguir ver, ouvir e, pois, absorver. É evidente que o Diário não representa o olhar fidedigno com as situações vivenciadas, mas são impressões construídas e que, por serem impressões, fazem parte das representações de espaço apreendidas (SEEMANN, 2003).

A forma de imersão ao grupo, presente na observação participante, não seguiu estritamente as diretrizes recomendadas por teóricos clássicos das ciências sociais, tal como Bronislaw Malinowski (1976), para quem a imersão ao grupo significaria uma forma de entender sua dinamização, sua construção identitária e mnemônica, e seu cotidiano no sentido profundo e concreto de vida. Tais diretrizes, por vezes, elencaria um tempo mínimo de permanência no interior de um grupo a fim de ultrapassar as barreiras do estranhamento.

Contudo, considera-se, evidentemente, não ser passível o conhecimento íntegro acerca do Outro, justamente por não se ser o próprio Outro. Desta forma, a fronteira de 
estranhamento se expressaria de diversas formas, e não somente a partir da duração cronológica do contato com o Outro. Tal maneira de imergir ao grupo se deu, portanto, em consonância com a proposta de Clifford Geertz (1989), para quem as técnicas de pesquisa devem ser contextualizadas conforme o objeto de estudo, e devem almejar a uma descrição densa que leve em conta à noção interpretativa de cultura. Dessa forma, os procedimentos se pautam no estabelecimento de relações com os assentados, a seleção de informantes, a transcrição e transcriação de textos, o levantamento de genealogias, a apreensão contextual e, pois, espacial e no próprio mantimento do Diário de Campo.

Todo esse processo levará em conta a seriedade e a importância do olhar, do ouvir e do escrever (OLIVEIRA, 1996), que podem ser subestimadas pelo seu caráter corriqueiro. Para o autor, esse processo aparentemente corriqueiro, quando problematizado e quando se respeita os limites que existem entre o $\mathrm{Eu}$ e o Outro, considerando também que a representação de pesquisa corresponde também a uma forma de representação do Outro, possui abertura interpretativa à textualização do Outro. Além disso, a rememoração que compreende a etapa da releitura do Diário de Campo revela-se crucial à textualização.

Há de salientar que esse processo de observação participante considerou o período que compreende a chegada ao grupo, ou aproximação. Os objetivos dessa pesquisa foram apresentados nessa etapa prévia ao que se chama de observação participante, que foi de certa forma facilitada pelo trabalho de monografia que criou alguma familiaridade para com o Eu que já observa há algum tempo a dinâmica do assentamento.

Já as entrevistas semiestruturadas seguiram os preceitos da história oral (MEIHY, 2009), usada frequentemente pelas ciências sociais e tem sido incorporada pela geografia e adaptada às suas investiduras específicas, tal qual tem sido feito por Alícia Lindón (2008). Esta autora reforça que é preciso estabelecer apenas um eixo temático norteador de pesquisa, que aqui é a história de luta pela criação do assentamento, de forma que tal eixo construa a orientação teórico-metodológica a qual denomina de histórias (ou narrativas) de vidas espaciais. Dessa forma, as perguntas não seriam rigidamente formuladas, respeitando-se somente o eixo de pesquisa escolhido e sobre o qual se daria a entrevista, abrindo-se ao diálogo e às representações as mais diversas. Essa metodologia não possuiu a pretensão de diminuir a carga de influência do Eu sobre o Outro que se investiga. É justamente por se assumir essa influência que esse eixo é apresentado ao entrevistado, sendo passíveis de interpretação inclusive os distanciamentos para com esse eixo, podendo ser entendido, por 
exemplo, como silenciamentos ou não-ditos (POLLAK, 1989).

Como se verá, as entrevistas - o que inclui o processo de gravação destas - não foram realizadas com o todo o grupo de assentados, que é constituído por doze famílias. Deparou-se com a composição de lideranças muito bem delineadas, que influenciou o processo de pesquisa na medida em que estava elencado aquele que sabe melhor da luta, e que poderia a este respeito conversar. Desta forma, foram apreendidos que certos territórios de memória são pertencentes à dinâmica do assentamento e à própria construção identitária de ser-assentado do Cafundão. Sobre isto, irá melhor se explanar. Neste sentido, a Travessia, denominada por Verdejo (2006) como caminhada transversal, contribuiu para transpor várias destas barreiras impostas através do andar pela terra, do incentivo de memórias para além do instituído, e do Eu que pôde observar dinâmicas e movimentações indo além do diálogo restrito ao histórico de luta. Neste sentido, considera-se a existência do Eu que representa as percepções obtidas do Outro, num trabalho de transcriação, em conformidade com Lucília Delgado (2006).

O instrumento da Caminhada Transversal ou Travessia que compõe o Diagnóstico Rural Participativo - DRP (VERDEJO, 2006) é interpretado como método qualitativo, o que ratifica a sua necessidade de apenas ser um caminho à apreensão daquilo que compõe o eixo de pesquisa. A Travessia foi assumida como um estímulo às lembranças contidas em situações ou acontecimentos que ocorreram nas terras que envolvem o assentamento. Em outras palavras, realizou-se Travessias pelas terras do assentamento onde a história de luta pela terra somada a outras lembranças nortearam justamente o caminhar.

Foram realizadas cerca de quatro visitas de campo, que compreenderam aproximadamente quinze dias de trabalho em cada uma destas ocasiões, sendo que todas as conversas foram gravadas por meio de gravador contido em telefone celular, para amenizar possíveis processos de intimidação.

A primeira visita, que se deu no início da pesquisa em maio de 2013, foi a mais curta por se resumir ao momento de aproximação para com o grupo estudado. Neste momento, apresentou-se a proposta, e conheceu-se vários assentados que ainda se mostravam intimidados. Aproveitou-se para prospectar informações junto à EMATER-Mariana e ao jornal O Monumento que estava em vias de ser descartado, pois não mais cabia na Biblioteca Municipal de Mariana. No segundo momento, já se permitiu que as gravações fossem feitas, e a Cooperativa foi apresentada. Presenciou-se momentos em que trabalhavam, enquanto o senhor Adão, o anfitrião deste assentamento, já se assumiu enquanto narrador da história de 
luta, e guia para demonstração de marcos de memórias pelas terras do Cafundão.

O terceiro campo continha o equipamento GPS para auxílio em georreferenciar o que estava sendo narrado, revisitado e rememorado por meio da Travessia. Neste momento, percorreu-se mais a fundo as terras do Cafundão e a própria memória do senhor Adão se manifestou de forma gratuita e sem estranhamento. O terceiro campo configurou-se enquanto ratificação do interesse desta pesquisa pelas suas memórias. Nesta ocasião, houve inclusive o registro de sentimentos profundos se expressando na forma de lágrimas. Teve-se duas certezas: a da confiança com o Eu que observa, e a de ter atingido marcos profundos de memória.

E o quarto campo norteou-se pela entrega de um banner, exposto mais a frente no texto, enquanto primeira devolutiva de pesquisa, bem como pelas andanças pela terra, ainda na Travessia, mas com incentivos ligados à memória de viver nestas terras, na tentativa de deslocar-se do eixo da história de luta. Neste momento, apreendeu-se elementos ligados, por exemplo, ao saber relacionado a plantas medicinais. O mecanismo contribuiu, portanto, para a apreensão de elementos que talvez componham as biografias espaciais.

Assim como, inquiriu-se no processo investigativo por registros documentais que manifestassem formas interpretativas dos contextos dos quais o Cafundão poderia fazer parte, bem como algumas formas de representação sobre os assentados e sobre a luta pelo assentamento. Aqui serão consideradas as abordagens do Estado em sua expressão escalar de ser nacional, estadual e municipal; da Igreja Cristã da Arquidiocese de Mariana; e um ponto de vista da mídia expressa no jornalismo local, que compõem uma das possibilidades existentes.

Por esse motivo, foram visitados jornais e documentos que não expressam necessariamente a opinião da Instituição à qual se vinculam, sendo eles: os jornais $\mathrm{O}$ Arquidiocesano (1972-1983), O Monumento (1989-1991), O Liberal (1994 - 2004) e O Ruralista (1983-1993), as Atas de Reunião Ordinária e Extraordinária da Câmara Municipal de Mariana (1989 - 1998); e os artigos que serão escritos mencionando-se, em poucas linhas, o assentamento Cafundão. Esse tangenciamento polifônico pretende-se estar pautado em formas de representação que se dão também a partir de sua rememoração, seja se dando através de oralidade, seja através de documentação. Fala-se de memórias, memórias da luta: polifônicas, particulares e em movimento. 


\section{Estruturação da Dissertação}

Desta forma, esta Dissertação está organizada em quatro capítulos, sendo que o último possui aspecto ensaístico à guisa de conclusões. O primeiro capítulo, Agrário e Agrícola em uma questão brasileira, é uma proposta de contextualizar o que se chama de historicidade da concentração de terras através do tratamento diferenciado que se tem dado aos aspectos agrário e agrícola brasileiros. Bem como, aborda-se os conflitos do Cafundão que atingia, no final da década de 1980, um patamar de atentar contra a vida daqueles que moravam nestas terras. O contexto fundiário desigual brasileiro se expressa, portanto, na localidade do Cafundão, que emerge enquanto território de luta à defesa do lugar - que possui memória, vínculos, saberes e vidas ligadas a esta terra.

O segundo capítulo, A política de reforma agrária e o cenário fundiário brasileiro, faz uma leitura breve da jurisprudência agrária a fim de ratificar que é histórica a desigualdade de acesso a terras no Brasil. Assim como, dialoga sobre a inserção da expressão reforma agrária no seio da política brasileira e, posteriormente, enquanto política que expressa um pacote de significados atrelados à mitigação deste cenário fundiário desigual. A transformação do termo em política contribui para que ela fosse empreendida enquanto resolução da tensão na e pela terra no Cafundão.

O terceiro capítulo, Sociogênese do assentamento: a reivindicação da reforma agrária dos assentados do Cafundão (Mariana-MG), contribui para que se entenda o processo de criminalização da luta pela terra através do posicionamento da Igreja, do Estado Ditatorial, e do imaginário do comunismo. Assim como, contextualiza o surgimento do MST enquanto movimento e pressão social. Ressalta o sentido diferenciado da luta pela terra do Cafundão calcada na memória e no sentimento de herança, a despeito de demonstrar que tais assentados utilizam o mecanismo da pressão social através do acampamento, convergindo-se às ações do MST, enquanto forma de fazer-se visto à resolução de conflitos e tomadas de atitude. A conquista em torno de ser beneficiário de reforma agrária contribui à construção da identidade ser-assentado, que sustenta a legitimidade do vínculo com a terra expressa no saber-fazer panela.

Já o último capítulo, À guisa de uma conclusão: memórias e identidades territoriais, configura-se num ensaio teórico acerca da impressões de pesquisa ligadas à construção de 
memórias, identidades e territorialidades através do vínculo com a terra e da possível emergência teórica de se conceber ruralidades. 


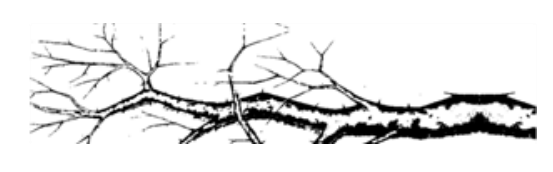

\title{
Capítulo 01
}

\section{Agrário e agrícola em uma questão brasileira.}

\begin{abstract}
"Acontece todo día: a gente só tem olhos para o que mostra a nossa janela, nunca a janela do outro. $\bigcirc$ que a gente vê é o que vale, não importa que alguém bem perto esteja vendo algo diferente. Eu costumo dar uma espíada no ângulo de vísão do vízinho. Me déxa menos enclausurada nos meus própríos pontos de vistas, mas, em contrapartida, me tíra a certeza de tudo. Dependendo de onde esteja posícionado, a razão pode estar do nosso lado, mas a perderemos assím que trocarmos de lugar. Só possuíndo uma vísão de 360 graus para nos declararmos sábíos. E a sabedoría recomenda que falemos menos, que batamos menos o martelo e que sejamos menos enfátícos, poís todos estão certos e todos estão errados em algum aspecto da análise. É o tríunfo da dúvída!” (Martha Medeíros).
\end{abstract}

\subsection{Elucidações I}

Da sede do município de Mariana, anda-se por cerca de 25 quilômetros de estradas asfaltadas, pela BR-381, sentido Ponte Nova - MG. À direita, há um trevo que marca o início do distrito Cachoeira do Brumado. 
Figura 1: Trevo de entrada para o distrito Cachoeira do Brumado (Mariana-MG). Acervo de pesquisa (2013).

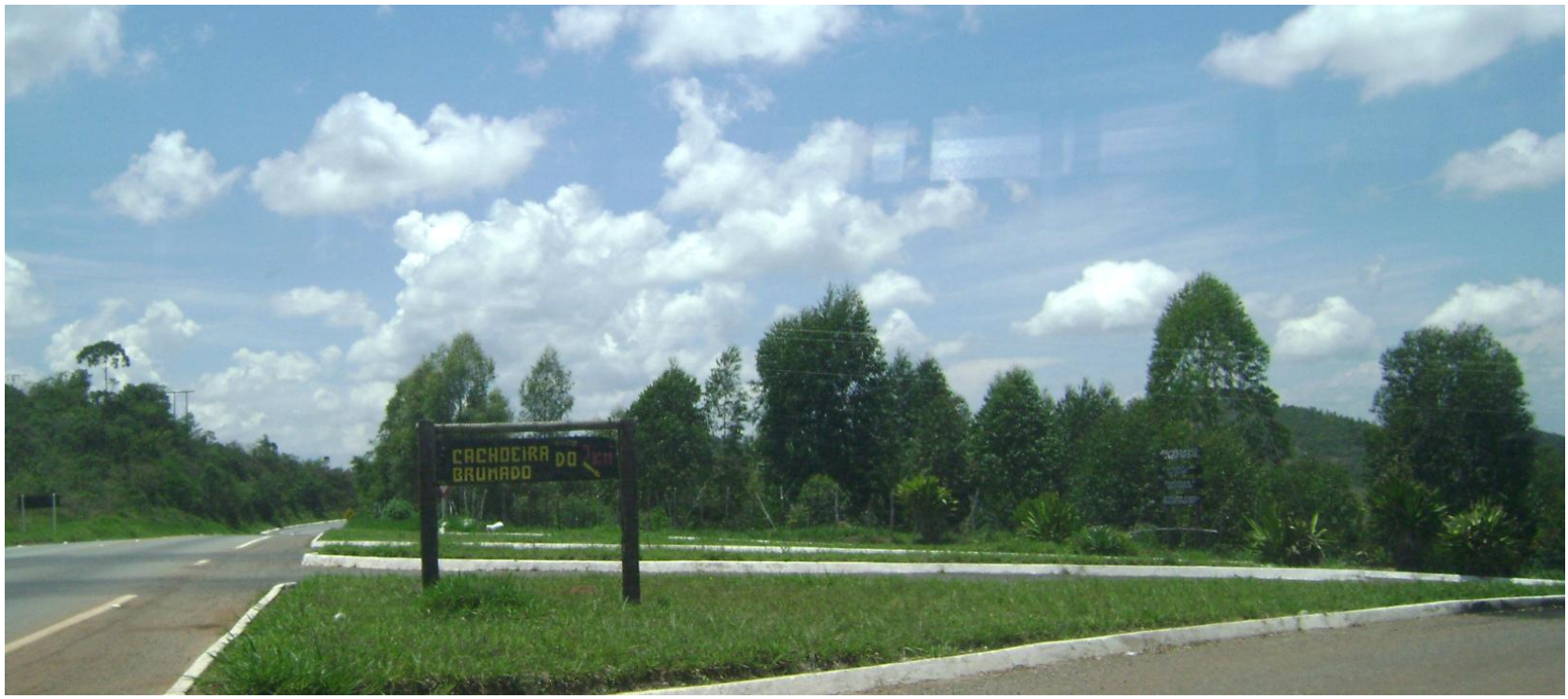

Vê-se, na entrada, um restaurante abandonado e com grande parte de sua estrutura furtada. Segue-se descendo pela estradinha, ao lado do restaurante, que recebeu asfalto novo há alguns dias. Nessa estrada repleta de curvas é possível passar exatamente dois automóveis, e não conta com acostamentos.

Figura 2: Estrada de acesso para a sede do distrito Cachoeira do Brumado (Mariana-MG). Acervo de pesquisa (2013).

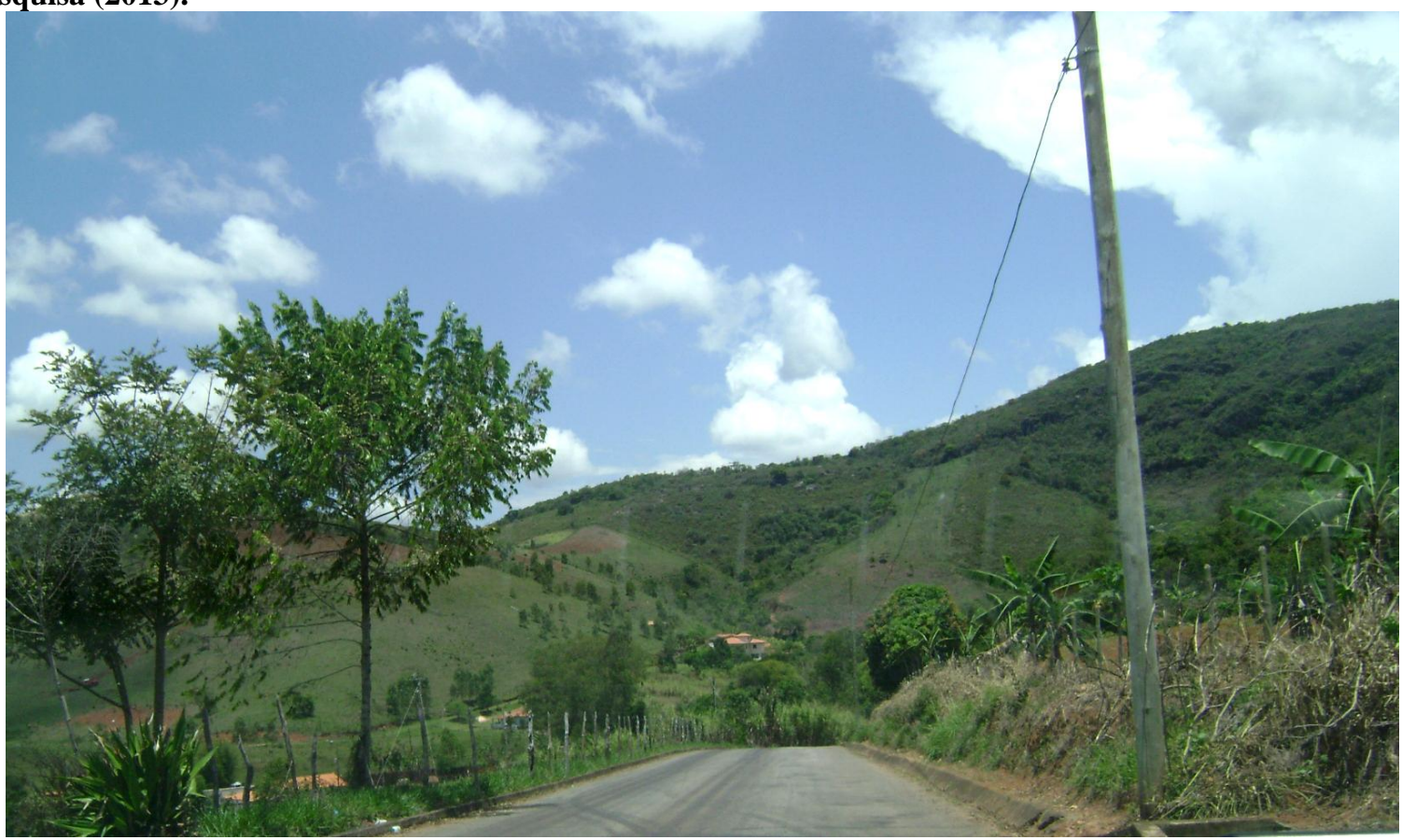


A descida dessa estrada termina com a subida de uma nova escarpa, de onde se vislumbra uma paisagem com alguns pontos densos que marcam a presença da vegetação de transição entre cerrado e mata atlântica, alguns campos de pastagens em áreas menos íngremes em meio a morros. Percebe-se um loteamento recente com linhas de distribuição de energia e casas maiores. Vê-se outras casas simples, com horta, e animais dentro dos limites do cercado feito com madeira, sendo alguns contáveis bois, cavalos, vacas, porcos. Galinheiros se fazem presentes em quase todas estas últimas casas. Uma sensação de silêncio, interrompidos por rádios ligados, também.

Sabe-se que essa estradinha termina na sede deste mesmo distrito, deparando-se com uma cachoeira formada por um rio que dá nome a esse local. Brumado incita nebulosidade, não percebida nos ensolarados dias em que se foi.

Figura 3: Visão, ao fundo, da cachoeira que dá nome ao distrito: Cachoeira do Brumado. Foto tirada no acesso ao Cafundão de Baixo. Acervo de pesquisa (2013).

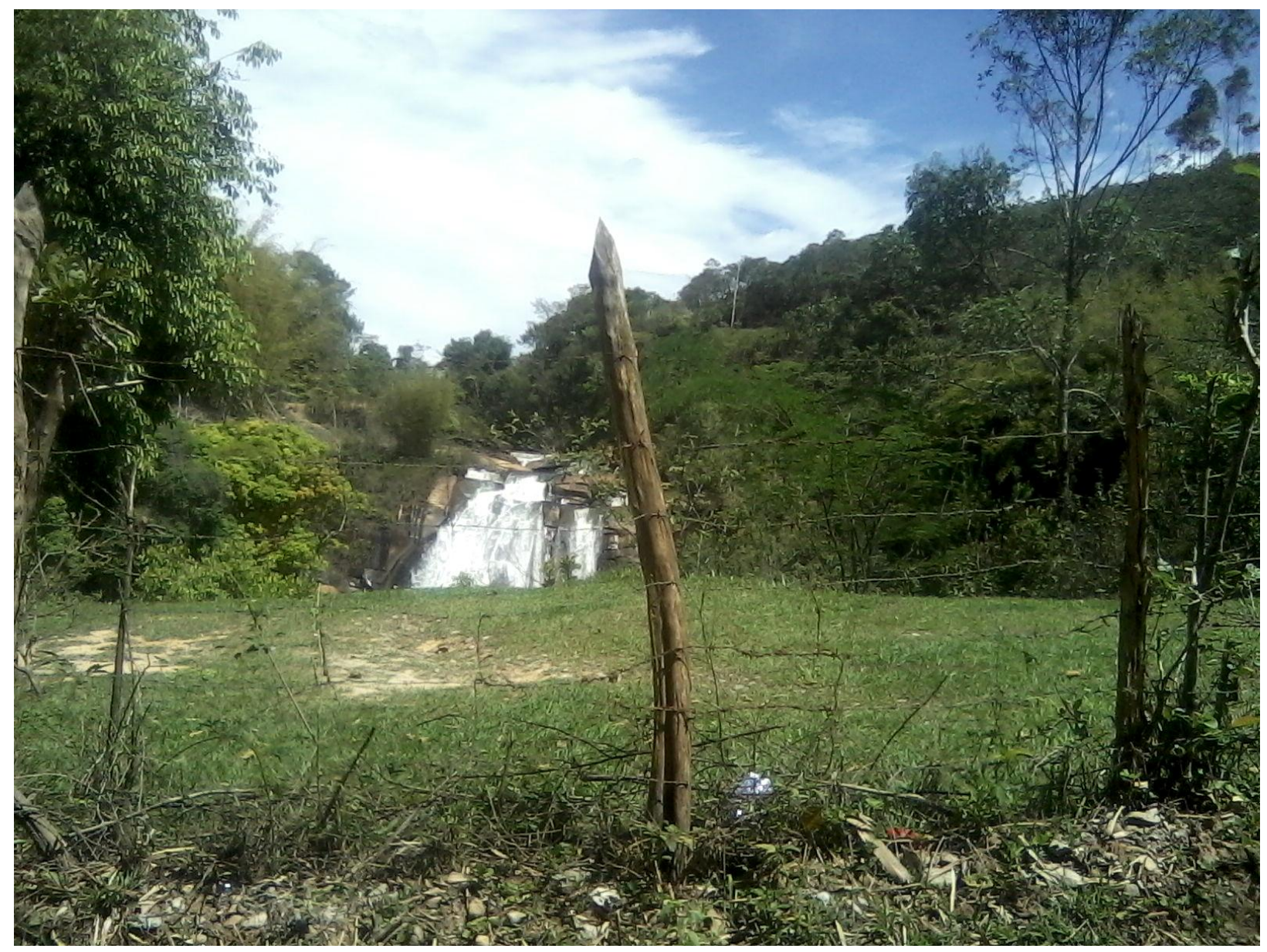


Percebe-se diversas oficinas de torneamento de pedras, que serão usadas no artesanato ou na própria venda dos blocos. Nota-se duas pousadas, o que revela o turismo em torno principalmente da cachoeira e de sua calmaria, que atrai no final de semana pessoas do município de Mariana. Grandemente, trata-se de pais que levam seus filhos, ou casais. E algumas lojinhas pequeninas de artesanato em pedra-sabão, coloridos tapetes, panelas em cobre para feitio de doces caseiros com tempo longo de cozimento, imagens religiosas, esculturas conhecidas como namoradeiras, e vários outros.

Pela sede do município, segue-se descendo virando-se sempre à direita, para que se chegue às terras do Cafundão. Por esse caminho, é possível conhecer todo o Cafundão, inclusive aquela parte que não integra o assentamento. Vê-se um misto de pequenas casinhas com pinturas descascadas, e casas maiores, com muros altos e algumas com cerca elétrica. Esse primeiro Cafundão, chamado "de Baixo", é mais denso, com casas coladas umas nas outras, ou com muros, intercalados por terrenos onde se vê maquinários, blocos espalhados, e homens com calça e botas, repletos de pó. Onde se vê também crianças em bicicletas, e senhoras na calçada de sua própria casa, talvez.

Figura 4: Senhor Adão mostrando os moinhos usados no Cafundão de Baixo. Como estavam trancados, tirou-se fotografias do lado externo e, ao burlar a cerca, do lado interno do moinho. Lado externo da casa do moinho. Acervo de pesquisa (2013).

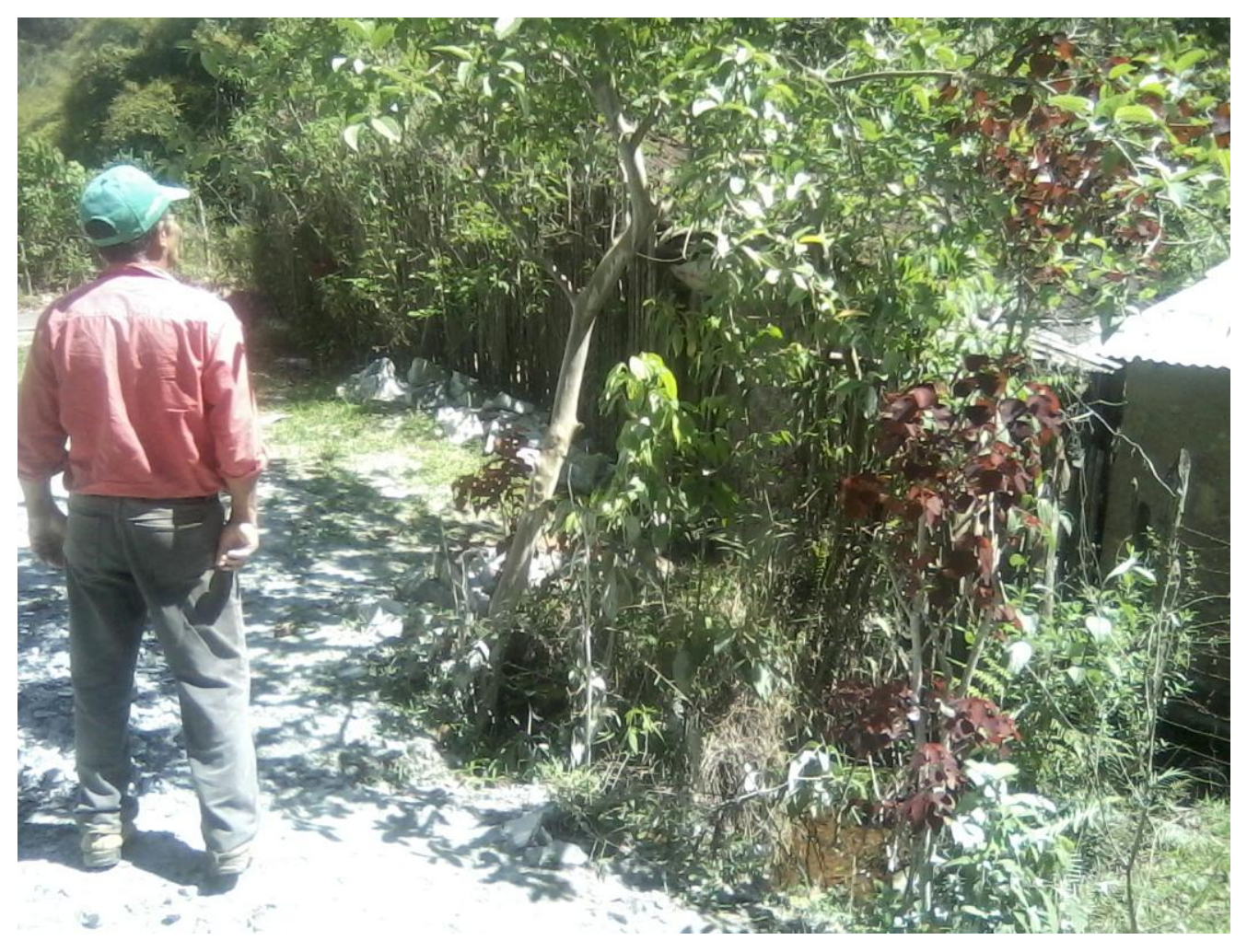


Figura 5: Lado interno do moinho situado no Cafundão de Baixo. Acervo de pesquisa (2013).

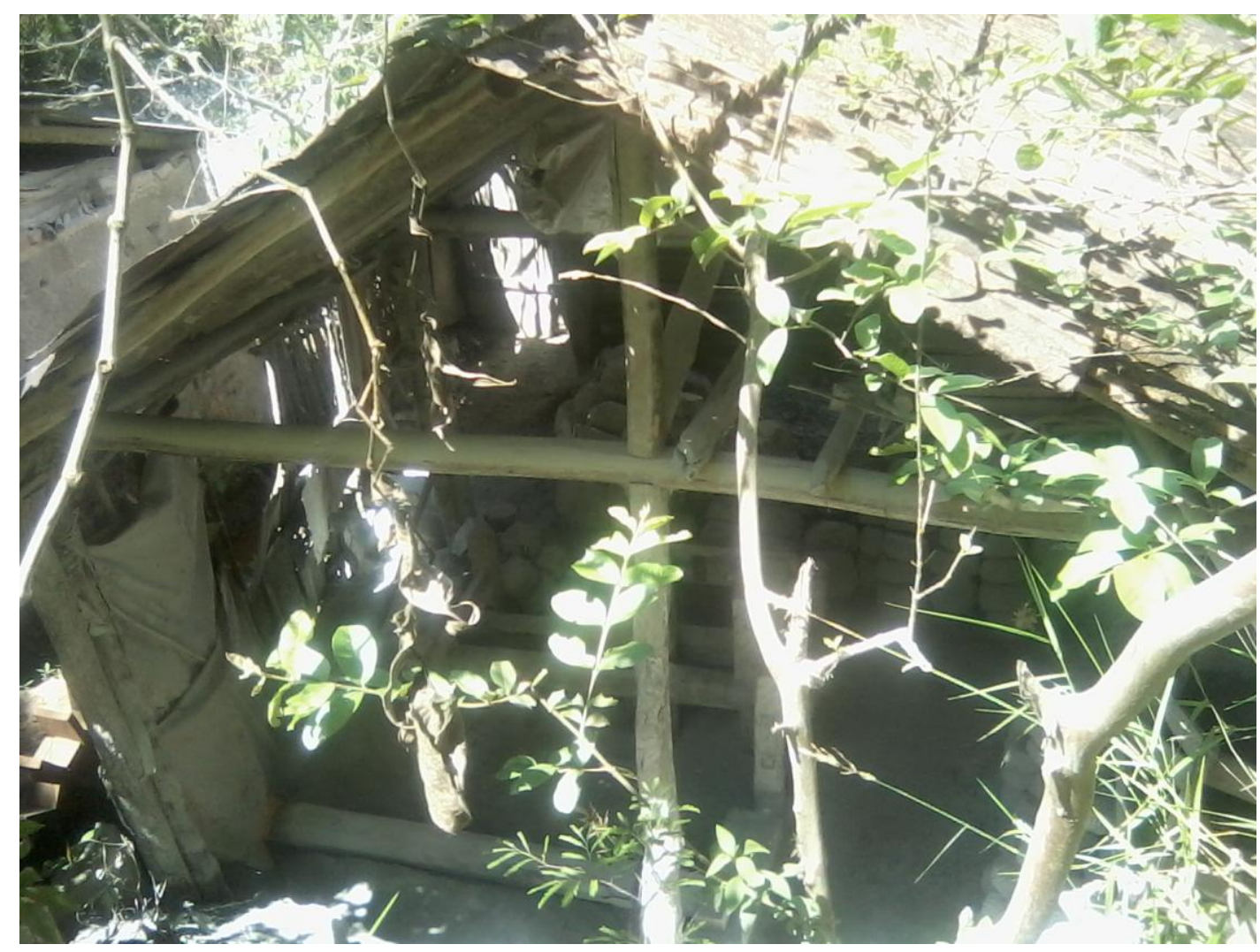

Os limites que marcam a divisão do Cafundão "de Baixo"2 e do Cafundão "de Cima" é uma rotatória de retorno do ônibus circular que não adentra as terras de Cima, e que delimita também até onde o asfalto se faz presente. Questionando o porquê das terminologias Cima e Baixo, percebe-se se relacionar à posição na vertente destes sub-bairros.

Não somente isso. Dona Sandra, assentada, diria que é por que consideram o assentamento mais perto do governo, que está em cima. Percebe-se também que o concordar com o estar próximo ao governo faz com que eles mesmos se identifiquem com a terminologia. E em outros momentos, revelam que sempre houve esses nomes para tais subbairros. Mas, sem dúvida, são diferentes. E chamá-la de Dona é respeitar a forma como a ela referenciam, como se percebeu depois.

\footnotetext{
${ }^{2}$ As aspas foram usadas para destacar as terminologias Cima e Baixo enquanto denominações de duas partes que integram todo o bairro Cafundão, que pertence ao distrito de Cachoeira do Brumado, em Mariana-MG. De agora em diante, não se utilizará esta forma de destaque.
} 
Figura 6: Rotatória que marca o limite do percurso do ônibus, que faz o trecho sede de Mariana ao distrito de Cachoeira do Brumado. Configura-se também enquanto limite à presença de asfalto. A partir deste ponto, no sentido assentamento, tem-se a estrada de terra. Acervo de pesquisa (2013).

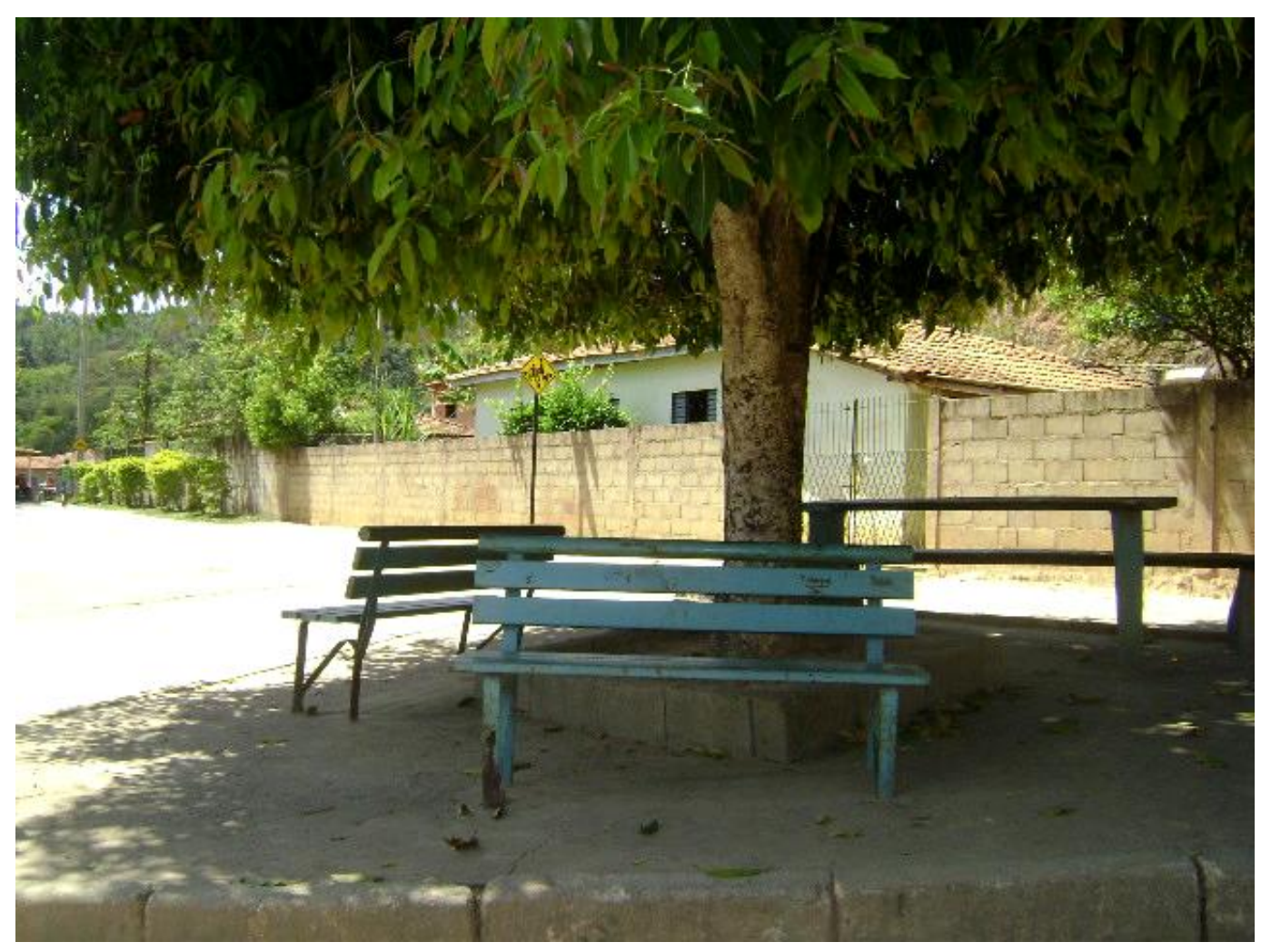

Há suspeita de tensão entre sub-bairros. Percebeu-se pela presença e ausência de asfalto. Percebeu-se também ao questionar moradores do Cafundão de Baixo se conheciam o senhor Nilton da oficina de pedra do Cafundão de Cima, esposo da Dona Sandra, ou ao menos se conheciam o assentamento. Como estas referências eram ali desconhecidas, apontou-se somente para que lado seria o Cafundão de Cima, e que lá se acharia quem estivesse procurando. Algo curioso, já que compartilham de uma mesma vertente há vários anos.

Dar-se-ia pra se chegar ao Cafundão de Cima sem percorrer toda a estrada que leva à sede. Na segunda ocasião, tentou-se descobrir tal caminho. Neste caso, os informantes não seriam mais aqueles do Cafundão de Baixo. Seriam agora aqueles que integram o novo loteamento, situado no topo da vertente, bem próximo à referida $\mathrm{BR}$. Uma área que já conta com casas muito maiores se comparadas com aquelas encontradas na sede. Feitas em madeira, com estilo rústico, construídas em grandes lotes, alguns já com piscinas, e muros altos. Não será preciso dizer que, se não havia sinalização indo pela sede do distrito, não era identificável qual caminho escolher para se chegar ao assentamento, ou Cafundão de Cima, por este caminho tomado. Aliás, estes dois - o assentamento e o Cafundão de Cima - não são 
correspondentes. O assentamento está em terras que pertencem ao Cafundão de Cima, explica-se.

Figura 7: Estrada de acesso ao assentamento Cafundão, passando pelo loteamento Bela Ville que possui plantação de eucalipto e casas maiores em relação à maioria daquelas de todo o distrito. Acervo de pesquisa (2013).
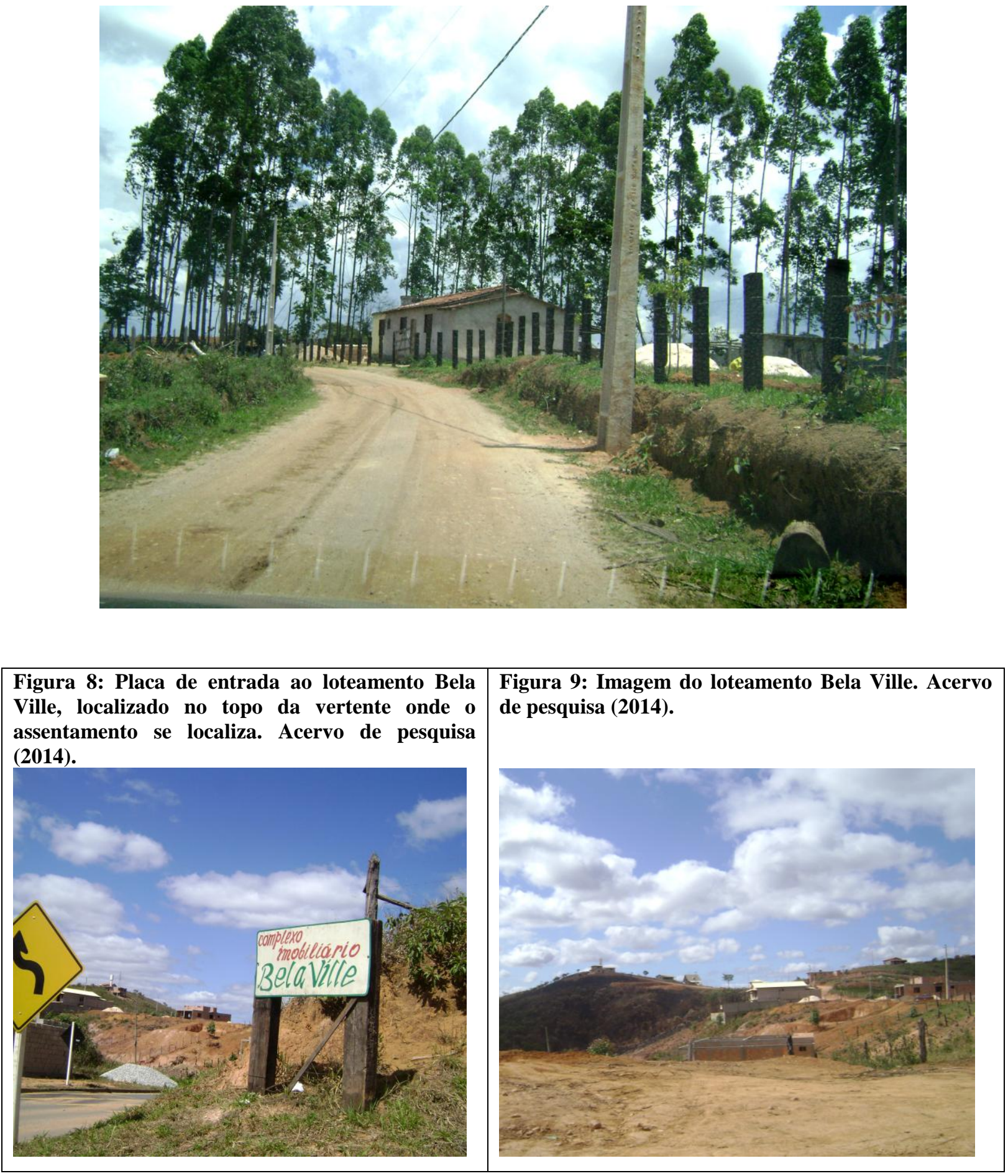


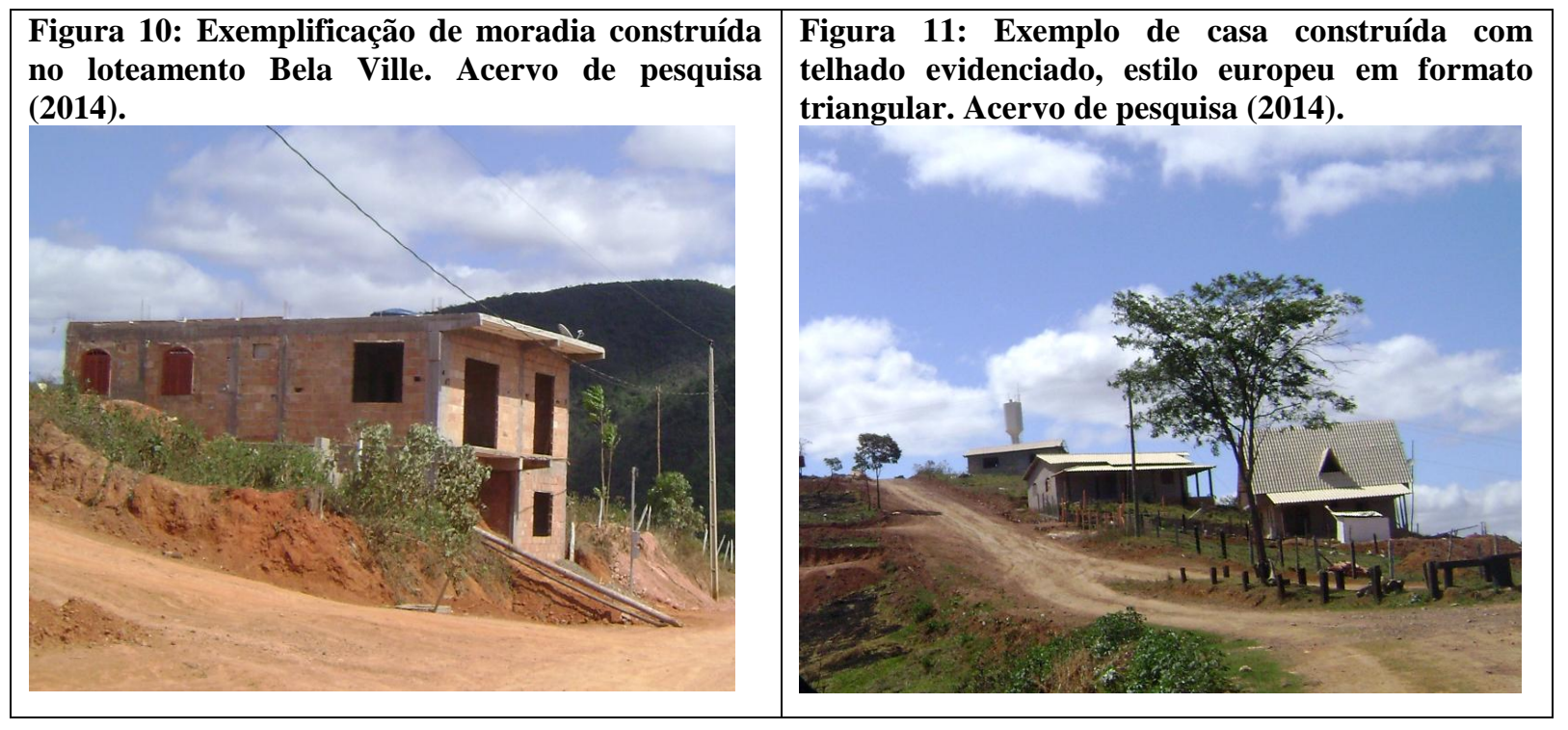

Este caminho se tomava no início da estrada que leva à sede, virando-se à direita. Era uma estrada de terra, que era larga até os limites do loteamento, a ponto de caber três caminhões lado a lado. Viu-se tratores dividir a estrada com caminhões que transportam água potável, chamados de caminhões-pipa. Dessa larga estrada, deparou-se com uma outra à direita, estreita, arenosa e extremamente íngreme. Não se tinha certeza que iria se chegar ao assentamento, mas sabia-se muito bem que qualquer manobra de retorno era impossível de ser feita. Desceu-se por cerca de cinco minutos, e avistou-se a primeira casa. [...]

Chegar ao assentamento Cafundão se utilizando de escopos teóricos configura-se no maior desafio dessa pesquisa. Sabe-se que o interesse pelas memórias e identidades dos assentados, que revelam elementos presentes em sua origem social e as motivações da luta pela terra, não se bastam em suas próprias falas. Não se teria os elementos necessários à compreensão do que foi e porque se deu essa luta, ou o contexto em que foi engendrada, sem que se considerasse o assentamento para além dele próprio. Aliás, estuda-se aqui memórias e identidades que reforçam a necessidade de se encarar o assentamento enquanto algo em movimento, plural, e formado por pessoas que buscaram ser assentados. Os assentados, e sua luta pelo assentamento, se circunscrevem enquanto recorte aproximativo de pesquisa. 
Essa forma de abordagem, de considerar o assentamento fronteiriço à história de construção do espaço brasileiro, induz a um movimento de pesquisa. Fala-se da espacialidade da luta, que reclama por encará-la em planos escalares. Ter-se-ia que considerar as tensões presentes num cenário brasileiro, que se respaldam sobre as decisões tomadas pelo Estado de Minas Gerais, que resvalam em características aninhadas ao município de Mariana, que criam particularidades inerentes ao distrito de Cachoeira do Brumado, que estabelece tensões entre o Cima e o Baixo do Cafundão, que reflete sobre tensionamentos entre o próprio grupo que lutou para ser assentado, e no interior de suas famílias. Este movimento de pesquisa poderá proporcionar o estudo do Cafundão como pertencente a um cenário maior que lhe dá sentido e substância.

Contudo, o trabalho de Lygia Sigaud (2005), sobre as formas de ocupação nas zonas canavieiras de Pernambuco, contribui para se atentar para tal movimento de pesquisa. Em seu trabalho, se percebe a construção dos planos escalares, mas se dando de forma tão complexa que não se faz patamares de alcance. Em outras palavras, não se coloca isto como pertencente a um plano geral, e aquilo ao plano particular ou local. Geral e particular não estabelecem entre si relações de oposição: eles se fundem e se confundem, a despeito de serem diferentes em termos escalares. Conforme Milton Santos (2006),

[O particular] aparece como se fosse separado, existindo por si, mas é sustentado e contido no todo. O particular se origina no universal e dele depende. Daí o erro stalinista, apontado por J. J. Goblot (1967, p. 16), de transportar o universal no particular e logo expulsar este último do universal; um enfoque "duplo e contraditório". Inspiremo-nos em Cassirer (vol. 1, 1953, 1965 , p. 105) para considerar que o movimento da totalidade permite entendê-la, num primeiro momento, como uma integral e, num segundo momento, como uma diferencial. Enquanto integral, a totalidade é vista como algo uno e, frequentemente, em abstrato. Enquanto diferencial, ela é apreciada em suas manifestações particulares de forma, de função, de valor, de relação, isto é, em concreto (SANTOS, 2006, p. 78).

Ou seja, a concretude da investigação que reside na análise do particular não pode inibir seu caráter de pertencente ao todo e de ser expressão do próprio todo. Concorda-se com o movimento de pesquisa de Lygia Sigaud (2005) e com os contextos escalares que devem ser admitidos nesta pesquisa, e por isso decidiu-se inscrever as memórias da luta pela terra do Cafundão "na história das relações sociais em que ocorriam e, sobretudo, procurou-se compreender a motivação dos que lá se encontravam" e por isso seu exame deve ser feito "a 
partir de quadros sociais e históricos mais amplos" (SIGAUD, 2005, p.276). Assim, ter-se-ia que compreender o Cafundão pertencente àquele movimento de pesquisa, que o considera como manifestação de um cenário mais amplo de tensões pelo uso e apropriação de terras brasileiras.

Fala-se de incidir imaginários generalizados que desconsideram as histórias individuais de luta dos assentados de reforma agrária, concebendo-os como mera reprodução de uma política, em alguma medida, remediadora de desigualdade agrária. Geral e particular se fundem e se confundem, e estão para além de uma oposição binária (POLLAK, 1989). Assim, considerar o assentamento como uma mera expressão de resultado de uma política talvez iniba suas representações particularizadas, híbridas, plurais.

Aliás, segundo José Roberto Pereira (2001), essa concepção é arraigada ao sentido de conceber os assentados de reforma agrária ou como aspirantes a grandes agricultores ou como agricultores familiares sobrepujados por um sistema brasileiro que prioriza a agroexportação (ALMEIDA, 2000). Isso incide sobre a designação do caráter da luta pela terra reduzida a um aspecto comum, que é em grande medida estritamente vinculado ao seu viés econômico, o que cria uma homogeneidade que acaba ofuscando as particularidades que habitam o sentido de se lutar por uma terra. Ou seja, concebe os assentados como o Outro não no sentido que se almeja dar aqui como reforço de alteridade, mas reforça-o como um grupo homogêneo, e de certa forma padronizado pela designação de ser um assentado de reforma agrária.

Esta concepção é interiorizada no exercício acadêmico através, por exemplo, dos pressupostos teórico-metodológicos que sustentam a Geografia Agrária, enquanto campo disciplinar da ciência geográfica. Não irá se estender neste assunto, a despeito de ele ser extremamente importante ao entendimento das formas como a realidade tem sido apreendida, teorizada e reconstruída por essa ciência. Contudo, Ariovaldo Umbelino de Oliveira (1999) destacou duas perspectivas percebidas por ele como marcantes do pensamento geográfico no que concerne à questão da terra, e que fundamenta ou fundamentou o que se chama de Geografia Agrária do Brasil. A primeira delas diria respeito a conceber o campo como algo a ser desenvolvido a partir da inserção de capital. Para estes teóricos, haver-se-ia inclusive relações feudais que antecedem a entrada do capital no campo, e depois de sua inserção se conquistaria o desenvolvimento e avanços econômicos. Na esteira deste pensamento, a reforma agrária contribuiria para o desenvolvimento do campo a partir da otimização e ampliação de sua produção. Oliveira (1999, p. 70, grifos nossos) diz que "entre os principais 
estudiosos que seguem essa concepção estão Maurice Dobb, Nelson Werneck Sodré, Alberto Passos Guimarães, Inácio Rangel, etc. O livro Estudos de Geografia Agrária Brasileira, de Orlando Valverde, apresenta esta interpretação...”.

E a segunda perspectiva percebida por Oliveira (1999) seria aquela que diz respeito ao desaparecimento gradual do que se chama de campesinato, a ponto de ser defendida a própria ideia de sua morte enquanto dissipação deste grupo social. Essa ótica remete a entrada do capital como elemento que faria uma diferenciação entre aquele que seria camponês - e que ainda não era contemplado pela necessidade de ter que atender a um mercado - e aquele chamado de proletário, já inserido nessa trama do capital.

Entre os principais pensadores dessa corrente estão Karl Kautsky, Vladimir I. Lênin, Léo Huberman, Paul Sweezy, Caio Prado Jr., Maria Conceição D’Incao e Mello, José Graziano da Silva, Ricardo Abramovay etc. A maior parte dos trabalhos em geografia agrária têm por base essa concepção. São exemplos dessa corrente ... a maior parte das teses e dissertações defendidas na Geografia [...]. Mas, talvez, pelo seu caráter emblemático, o trabalho de Ruy Moreira "O desenvolvimento do capitalismo e o lugar do campo no processo" publicado na revista Terra Livre $\mathrm{n}^{0} 1$, seja um dos melhores exemplos dessa corrente na geografia agrária. (OLIVEIRA, 1999, p.71)

A despeito destas duas correntes substanciarem a construção da Geografia Agrária, Oliveira (1999) aponta um dos problemas que estas possuem. O autor destaca que o a priori da investigação desta linha de pensamento concebe a sociedade dividida em duas classes sociais, a burguesia e o proletário, e essa divisão ofusca o camponês. Essa problematização realizada por Oliveira (1999) é importante do ponto de vista que destaca uma realidade diferenciada do mundo do trabalho que se dá em áreas, diga-se, urbanas. Enfatiza também a importância do olhar diferenciado sobre os processos que se dão na questão da terra como um todo, incluindo sua face agrário-agrícola.

Porém, aloca os camponeses numa nova classe social, que é aquela da renda nãocapitalizada. Este autor avança do ponto de vista epistemológico por trazer a dialética materialista-histórica para o centro do debate. Mas, desconfia-se aqui da categorização do sercamponês como terceira classe. E, mais ainda, não se assume a classe como a priori da investigação.

Sobre as escolhas feitas para esta Dissertação, explica-se. A primeira perspectiva problematizada se dedica a estudar os pequenos produtores enquanto aqueles que desejam 
ampliar sua produção e inserir-se na rede dos grandes sistemas produtivos. Seriam, portanto, aspirantes a grandes produtores. Esta linha, ao associar o processo da reforma agrária à inserção e ampliação de produção, dissolve a luta pelo acesso a terra em prosperidade econômica. E a segunda perspectiva diz respeito àqueles que se enveredam pela tentativa de identificar um possível processo de sobreposição e até desmantelamento de pequenos produtores por aqueles grandes, ligados à agroexportação. Neste caso, as análises acontecem sobre uma base dual, onde o grande produtor contribui para o desmantelamento da grande massa de agricultores familiares através de seu sistema produtivo que os sobrepujam. $\mathrm{Na}$ esteira deste tipo de enfoque, os pequenos produtores e aqueles que lutam por um pedaço de terra buscam possuir voz num cenário que o oprime. Uma voz que ainda não se tem: se tratando, portanto, de algo a se conquistar.

Estas duas formas de a Geografia Agrária descortinar os processos sociais percebidos na construção do espaço brasileiro possuem um fator de homogeneização: fala-se de, por vezes, elas significarem um a priori da investigação. Ou seja, é exigido certo posicionamento teórico frente à Geografia Agrária ao pesquisador interessado num grupo específico, que se relaciona à reforma agrária. É exigido que se elucide se o grupo a ser pesquisado se relaciona àqueles oprimidos por latifundiários e/ou se correlaciona àqueles que se inserem numa rede produtiva de desenvolvimento econômico, e de que forma isso acontece. Ou se ainda ele corresponde à terceira classe social de camponês identificada por Oliveira (1999).

Foi sugerido, na ocasião da Qualificação de Mestrado $^{3}$, que fosse feito justamente este tipo de posicionamento na pesquisa. Na Geografia Agrária, repartida de forma não oficial, mas apresentando estas duas ou três filiações ou tipologias de análise, a qual grupo os assentados enfocados se encaixariam? Seriam aqueles inseridos na condição de marginalizados pelo capital ou aqueles outros que desenvolve ações, investimentos e atividades a fim de se aproximar da organização industrial e econômica do grande produtor?

A este respeito, José Roberto Pereira (2001) aponta o problema que esse tratamento homogêneo, que é pautado nas tipologias, gera, por exemplo, em políticas assistenciais ou estudos intervencionistas que tendem a ser generalizantes por entender um grupo como entidade homogênea que carece de intervenção imediata e até verticalizada. O que inibe, dessa forma, as particularidades que ocorrem no interior do grupo de assentados de reforma

\footnotetext{
${ }^{3}$ Ocorrida no mês de março do ano 2014, cuja banca se constitui dos professores Dra. Bernadete Aparecida C. de Castro (IGE-UNESP, Rio Claro), Dr. Everaldo Batista da Costa (GEA-UnB), Dra. Christiane Machado Coêlho (SOL-UnB).
} 
agrária que estar-se-iam ligadas ao sentido de se lutar pela terra, incluindo suas pretensões, objetivos de vida, e narrativas de mundo que são feitas.

Assume-se, portanto, a existência de análises diferenciadas que elucidam sobre as lutas pela e que se dão na terra. Porém, assume-se aqui partir primeiramente da leitura deste contexto específico ao qual se refere. Ou seja, é hipotético que a investigação de memórias e de identidades possam revelar o contexto de surgimento do assentamento, através de um olhar etnográfico como ponto de partida para a posterior apreensão desses planos escalares que se almeja também apreender. Dessa forma, tenta-se criar uma forma teórico-metodológica de estes planos escalares serem percebidos através das memórias de suas construções e narrativas, assumindo movimentos e contextos de espaço, ou biografias espaciais (SOUSA, 2010).

Este posicionamento assumido se alinha ao conceito de sociogênese como fundamento teórico-metodológico da própria pesquisa. $\mathrm{O}$ conceito sociogênese foi trabalhado de algumas formas por diferentes ciências. Na Psicologia, por exemplo, Elisabeth Rosseto e Gabriela Brabo (2009) enfatizam que ele se relaciona ao próprio objeto de pesquisa desta ciência. Ao investigarem o pensamento de base materialista-dialética que Lev S. Vygotsky possui acerca dos conceitos de sujeito e de subjetividade, elas se depararam com outras concepções de autores diferentes que tendem a se filiarem a dois grupos de pensamento: o primeiro "tende a privilegiar o funcionamento intra-individual e o outro, o interindividual. $\mathrm{O}$ funcionamento voltado para o caráter intra-individual foi denominado de sociogênese e o de caráter interindividual, de intersubjetividade" (ROSSETO e BRABO, 2009, p. 04).

Acerca do conceito de sociogênese, Rosseto e Brabo (2009) destacam como sendo a maior referência a este respeito na Psicologia Jaan Valsiner. Este autor estabelece uma oposição entre sociogênese, "que enfatiza a relevância do mundo social na formação das funções psicológicas", e psicogênese, que diz respeito às próprias faculdades psicológicas. Em outras palavras, o que se pesquisa nestes estudos são as formas como o mundo social interfere na formação do sujeito. Neste sentido, a Psicologia estaria preocupada com os modelos de transmissão que se dão entre o individuo e o seu mundo. Jaan Valsiner consideraria ainda três tipos de sociogênese:

aprendizado harmônico, no qual o mundo social fornece as informações necessárias para o desenvolvimento pessoal, que faz com que o indivíduo se torne "socializado" harmoniosamente, um participante da sociedade; fusão, que seria a unificação dos processos pessoais e sociais, que pode levar à 
dissolução do sujeito, já que não há peculiaridades que o separem do mundo social; e contágio, inspirado na metáfora das doenças contagiosas, aborda os mecanismos de infecção e imunização no qual a pessoa pode neutralizar a infecção ou resistir a ela. Este último Valsiner valorizou e nele baseou seu modelo sociogenético co-construcionista (ROSSETO e BRABO, 2009, p. 04-05, grifos nossos).

Estas três sociogêneses de Jaan Valsiner foram duramente criticadas por Vygotsky justamente por negar o caráter dinâmico e dialético da formação do sujeito, que se dá num processo que é histórico, é cultural e é também social. O limite entre o individuo e o seu mundo social, compondo o que se chama de intraindividual, seria mais fronteiriço a este mesmo mundo do que supõe as teorias de Valsiner.

Já em relação ao interindividual, ou intersubjetividade, que compõe o outro grupo identificado por Rosseto e Brabo (2009), estas mesmas autoras acusam um problema. Esta teoria do interindividual, pautada nas ideias de James Wertsch, é uma espécie de criação de níveis e de profundidade de intersubjetividade facilitada e construída por ferramentas socioculturais ou elementos semióticos, como a linguagem. De forma reduzida, a linguagem promoveria o interindividual, a relação entre dois indivíduos, a partir de uma harmonia entre estes mesmos indivíduos, e por isso se cria níveis e profundidades que estabelecem o quão é capaz de se comunicar. Ou seja, iria-se da comunicação à formação da mente, iria-se do inter ao intraindividual. Porém, tais autoras problematizam o fato de que esta relação intersubjetiva pressupõe a harmonia, o que as fazem indagar se em situações de conflito não haveria, portanto, a formação do individual?

É neste sentido que as teorias pautadas na dialética-materialista de Vygotsky ganham relevo na Psicologia, justamente por considerar a relação mundo social / indivíduo mais complexa, dinâmica, com historicidade de construção, e numa relação dialética entre o intraindividual e o interindividual. Estas análises se rearranjariam nesta textualização de forma a considerar a sociogênese também com base dialética-materialista, mas indo além dela. O mundo social adquiriria a significação de ser espaço, para assim se assumir outras formas de significação que vão além daquilo que é concebido como o social, abarcando as imaginações, as imagens, as formas pretéritas, as formas possíveis, o que não se percebe, e os devires.

Além disso, Rosseto e Brabo (2009, p. 07) destacam outras construções teóricas advindas desta base dialética de análise e que assume-se aqui enquanto posturas de pesquisa. 
Estas autoras destacam o pensamento de Smolka para quem a constituição do sujeito se dá dialeticamente. Destacam também o pensamento de Góes que concebe que "a individualidade é vista como um processo socialmente construído, sendo a singularidade uma conjugação que envolve conflitos, convergência e divergência, semelhanças e diferenças, aproximação e distanciamento com relação ao outro. Em última análise, o sujeito seria uma composição nada uniforme ou regular (não harmônica) dessas tensões e sínteses" (ROSSETO e BRABO, 2009, p. 07).

Neste sentido, o Outro passa a ser considerado como crucial à formação do próprio Eu. E este Outro é complexo, não-harmônico, se constrói dialeticamente no mundo e na fronteira com o Eu. Esta perspectiva nutre a forma de abordagem etnológica que considera que esta pesquisa é sobre a história de luta do outro sendo percebida por um Eu que não pretende ser invisibilizado, que não pretende falar pelo Outro, e que também não pretende dizer que o Outro assume aqui a própria voz da história que querem contar. Esta é somente uma versão da história de luta pela terra que deu origem ao assentamento Cafundão. Dialoga-se com as vozes dos assentados, o que dá relevo a elas, mas não se trata de um processo de dar-voz num sentido de que antes da pesquisa eles estariam amordaçados. Não. Estes assentados já conquistaram suas vozes na medida em que se tornaram assentados como garantia da construção espacial de si mesmos.

É por este motivo que aqui é assumido o conceito de sociogênese difundido nas ciências sociais que, por vezes, remete à ideia de origem social dos fenômenos. A noção de sociogênese que se utiliza se aproxima da ideia proposta por Norbert Elias (1994), e trabalhada por Lygia Sigaud (2005) na questão da terra, e comentada por outros autores tais como Landini (2007) e Miranda (2008). Entende-se a sociogênese enquanto conceito que abarca a ideia de gênese de um fenômeno se dando a partir de processos sociais específicos. Assim, a sociogênese disporia sobre acontecimentos determinados originados por dinâmicas sociais particulares e específicas, e que por este motivo tais fenômenos seriam particulares, plurais, e explicáveis somente a partir da historicidade de sua construção e de sua espacialidade. Para Luiz Francisco Miranda (2008, p.399), absorver a noção de sociogênese no inquérito de fenômenos sociais faz-se imperativo devido "a ideia de que [é] necessário entender a civilização como processo histórico no qual aspectos sociais e individuais articulam-se, pois o crescente controle dos impulsos passionais não afetam apenas a vida das artes." 
Essa articulação entre as formas e estruturas sociais e aquelas propriamente do indivíduo dá-se de tal maneira que é difícil estabelecer o limite de influência e regência do coletivo, em uma suposta contraposição com o individual. Miranda (2008) ressalta que duas noções são chamadas não para separar tais instâncias, e sim para ratificar que elas existem dialeticamente, quais sejam: sociogênese, para denominar formas sociais de produção do espaço, e psicogênese, ligada às estruturas de personalidade do indivíduo. Essa dependência entre o coletivo e o individual, ou entre a sociedade e o indivíduo (ELIAS, 1994), no que concerne à produção do espaço também se expressa, evidentemente, nas memórias e nas identidades que se formam a partir dessa produção. A construção de espaço reclama por memória, ao mesmo tempo em que a memória requer espaço para que se edifique (SEEMANN, 2003). Há interpendências entre esses aspectos que requerem maiores aprofundamentos, inclusive sobre as formas como, de fato, se correlacionam à formação das identidades. Por hora, uma breve análise acerca da formação de memórias coletivas e também das identidades poderia fornecer indícios de como uma análise de espaço requer que o entenda como algo que se expressa como numa sociogênese: ou seja, levando-se em consideração as formas sociais específicas de espacialidade que carecem de mecanismos também específicos de apreensão, inclusive de suas memórias e identidades.

Cabe destacar, que há o interesse não pelo significado rígido das memórias e das identidades coletivas ou pela delimitação empírica de uma coletividade. Em outras palavras, não se pretende verificar - no sentido analítico do termo verificar - até onde as coletividades memoriais e identitárias dos assentados estão presentes e a partir de onde esse limite-coletivo já não exerce o esforço de unicidade. Há, ao contrário, a pretensão de concebê-las, tal como a ciência ao qual se vincula, como conceitos moventes, abertas ao diálogo e ao atravessamento. Isso significa que se pretende aproveitar da mobilidade concernente à expressão coletiva - na análise de memórias e identidades -, por esta já se esbarrar por excelência em instâncias individuais e particulares e por ser difícil estabelecer uma delimitação; para entender o seu papel na produção de espaço e na sociogênese do assentamento Cafundão.

Porquanto, este primeiro capítulo pretende construir um diálogo entre elementos que compõem o que se chama de a questão da terra com as formas dela ser percebida pelos assentados, através do inquérito da história de luta pela terra do Cafundão. Salienta-se que este diálogo comporá todo o estudo e também por isso, somado a sua complexidade, sabe-se da impossibilidade de esgotar a ampla temática questão da terra. 


\subsection{Os confrontos no Cafundão: Lugar de guerra mesmo}

Eu imaginava que [o assentamento] era lugar de guerra mesmo. Por que o povo fugia pra mata. E o meu sogro estava sempre preso. O pai dele tava sempre no hospital. E a dona Cecília que teve depressão pós-parto, é uma pessoa assim, doente, né? Por conta de sempre... Fugiu pra mata na hora do parto, olha só! Aí ela teve problema de parto e hoje ela tem problema. É, como que chama... Problema assim mental mesmo. E o outro que foi baleado, essas coisas assim. Essa guerra mesmo ${ }^{4}$. (Dona Sandra, assentada, esposa do senhor Nilton, mãe de duas filhas, avó já no assentamento, natural da cidade de São Paulo).

A guerra apontada pela Dona Sandra se relaciona aos conflitos armados pela terra do Cafundão. Ela nasceu em São Paulo e casou-se com o senhor Nilton, que é nascido no Cafundão. Ele foi para São Paulo trabalhar numa metalúrgica, quando se conheceram e se casaram. Voltaram alguns anos depois, mediante o cenário apontado por ela como aquele em que Fernando Henrique Cardoso, então presidente do país, estava vendendo tudo, o reconhecido processo de privatização.

[Pergunto: o pessoal aqui é natural daqui mesmo?] É daqui mesmo, é daqui mesmo. Não, eu já sou de São Paulo. Eu vim de São Paulo pra cá. Por que meu marido já era daqui. Aí lá, ele já foi pra lá e não deu certo com a metalúrgica. Por que naquela época o Fernando Henrique tava vendendo tudo e ai ele ficou desempregado, aí ele falou assim 'eu sei fazer panela, vamos pra lá', aí eu vim com ele. Aí tem 16 anos que eu moro aqui. Mas, assim, o meu sogro morou todo o tempo, ai a gente sabia das [palavra não entendida], né? Primeiro quando estavam tomando do avô do Nilton as terras, e depois ele morreu. Aí, o pai do Nilton assumiu e depois o Nilton que assumiu (Dona Sandra).

Rafael Vaz da Motta Brandão (2013) contextualiza, em sua recente tese, os processos brasileiros de desnacionalização e privatização influenciados pela ideologia neoliberalista advinda de um cenário mais amplo e internacional, e que vivenciaram, portanto, o senhor

\footnotetext{
${ }^{4}$ Explica-se que se adotará a forma itálica e em texto corrente para referenciar as falas dos assentados. Estas falas foram captadas em ocasiões de pesquisa que ocorreram entre o período de abril de 2013 a janeiro de 2015, data do último trabalho de campo. Parte destas falas foram aqui transcriadas, conforme instruções de DELGADO (2006), para quem a fala apreendida já é, no processo de apreensão, uma construção nova, resultante do encontro Eu-Outro. Tem-se todas as entrevistas em áudio, disponível como acervo de pesquisa.
} 
Nilton, a sua família, milhões de pessoas, e também brasileiros. Este autor cita alguns exemplos do avanço dessa ideologia em detrimento daquilo que se denomina como welfare state, ou bem estar-social, onde o Estado assume a gestão do país e de sua economia, enquanto promotor social.

Alega que esta organização política-ideológica demonstra sinais de exaustão no póssegunda Guerra Mundial (1945-1954), tornando-se frutífera a difusão daquilo que estaria fundamentado justamente no contrário, ou seja, no Estado pautado na liberalização de sua gestão e economia. Ressalta que, enquanto política de governo, a primeira experiência neoliberal foi a chilena do General Augusto Pinochet que se deu na década de 1970, seguida dos Estados Unidos de Ronald Reagan e do Reino Unido sob o comando da Margaret Thatcher, ambos na década de 1980. Aponta que essa política se alastrou ao longo da América Latina na década de 1980, mostrando sinais de estar chegando ao Brasil nos governos do General João Baptista Figueiredo (1979-1985) e José Sarney (1985-1989).

Este autor salienta que os governos subsequentes de Fernando Collor de Mello (19901992), Itamar Franco (1992-1994) e Fernando Henrique Cardoso (1995-2002) "foram responsáveis pela implantação da política neoliberal no país, no qual as privatizações constituíram-se como elementos centrais nos seus governos" (BRANDÃO, 20013, p. 246). Ele se dedica especialmente ao período governado por Fernando Henrique Cardoso por que considerou que este

alterou algumas regras do processo de privatizações, estabelecendo novas diretrizes e ampliando o seu escopo. Nos seus oito anos de governo, FHC conseguiu aprovar mudanças constitucionais importantes, entre elas, a eliminação de restrições em relação ao capital estrangeiro, a quebra do monopólio estatal sobre a exploração do petróleo - abrindo espaço para os leilões de poços e campos petrolíferos a partir da criação da Agência Nacional do Petróleo (ANP) - e o fim do controle estatal sobre o sistema de telecomunicações, possibilitando a venda de empresas públicas na área de telefonia. Foram ainda, incluídos no PND [Plano Nacional de Desenvolvimento], o setor elétrico, as concessões das áreas de transporte, rodovias, saneamento, portos, as telecomunicações e o setor financeiro [...] (BRANDÃO, 2013, p.252-253).

Brandão (2013, p. 331), que escreve sobre as privatizações ocorridas no sistema bancário, conclui sua obra com a afirmação de que o governo de Fernando Henrique "foi o responsável pela reforma do Estado brasileiro e pela sua inserção na ordem neoliberal". 
Conclui que todo o pacote neoliberal foi responsável pelas demissões em massa de trabalhadores, pois este pacote não reside unicamente na venda de empresas estatais, como também inclui outros mecanismos como o enxugamento administrativo, as fusões de empresas, a participação do capital estrangeiro sendo ampliada, mudanças constitucionais, etc. Em suma, trata-se de uma série de medidas pautadas na crítica à intervenção estatal na economia, que subestimou, como destaca Pedro Henrique Carinhato (2008), as políticas sociais deste período, como aquelas ligadas à reforma agrária, como será visto no segundo capítulo.

Os episódios de guerra presenciados pela paulista dona Sandra, com o seu marido senhor Nilton, ao saírem de São Paulo e retornarem às terras do Cafundão, mobilizaram um sindicato de uma mineradora da cidade de Mariana, denominado de METABASE, no intuito de intervir enquanto pressão institucional no conflito. Há um Sindicato de Trabalhadores Rurais no município que, segundo os assentados, e a despeito de serem a ele filiados, nada fez para cessar a tal guerra. Vê-se um caso em que diferentes sindicatos assumiram distintos posicionamentos perante aquela guerra presenciada nas terras do Cafundão. Isso faz com que se abra um breve parêntese para destacar a atuação dos sindicados na história brasileira, principalmente no que concerne aos trabalhadores rurais. Para tanto, Amir El Hakin de Paula (2009) salienta que é preciso voltar ao processo de industrialização brasileira para entender a historicidade do movimento sindical.

Esta relação entre industrialização e sindicalismo é trazida por Paul Singer (1999) quando este remete à Inglaterra o pioneirismo de associações dedicadas a atuar em prol de trabalhadores. Isto por que, este cenário revela uma tensa relação entre a inserção de máquinas nas fábricas convivendo com a manufatura. Em outras palavras, os produtos industriais transformaram a estrutura do trabalho e promoveram concorrência entre aquilo que era produzido pela indústria que se daria numa maior escala e num menor tempo, bem como entre os próprios trabalhadores, que passaram a lutar pela permanência no emprego aceitando condições cada vez mais desumanas de trabalho.

Tais associações tentaram impedir justamente esta desumanização do trabalho mediante este processo conhecido como a Primeira Revolução Industrial. Nas primeiras atuações, pelo caráter violento das ações, como a queima de fábricas, estas tais foram consideradas ilegítimas e até reprimidas. Paul Singer (1999) prossegue destacando algumas influências que compuseram a matriz ideológica do movimento sindical, tal como se percebe 
no owenismo com influências socialistas, em que "os resultados do trabalho comum deveriam ser repartidos equanimemente" (p. 01). Até que se funda, em 1895, a Aliança Cooperativa Internacional que congrega entidades cooperativas de todos os países do mundo. Para este autor,

É necessário que os sindicatos acolham em seus quadros cooperadores da mesma forma que trabalhadores assalariados. [...] Sindicatos e cooperativas surgiram das mesmas lutas. Os sindicatos têm uma importante contribuição que já é uma realidade para a difusão do novo cooperativismo. Ampliar esta contribuição é urgente para reforçar o combate comum ao neoliberalismo, à perda de emprego formal e dos direitos conquistados (SINGER, 1999, p. 0102)

No caso do Brasil, segundo Amir de Paula (2009), alguns autores brasileiros tentaram associar a sindicalização ao avanço do neoliberalismo desencadeado pela economia cafeeira, tais como Warren Dean e João Manuel C. Mello. Mas ele sugere concordar com José de Souza Martins (1990) para quem “o aparecimento da indústria está vinculado a um complexo de relações e produtos que não pode ser reduzido ao binômio café-indústria" (MARTINS, 1990, p. 106). Isto porque, havia traços complexos do desenvolvimento de uma economia exportadora contribuindo para a formação da economia monetária, antes da dedicação brasileira ao café, e que deve ser considerado. Para Amir de Paula (2009),

Concomitantemente à industrialização, houve a formação da classe operária, composta em sua maioria por imigrantes, principalmente europeus, que ao país vinham em grande número. Sem quase nenhum amparo social do Estado e vivendo em uma condição de grande penúria, esses trabalhadores começaram a se organizar, primeiro em sociedades de apoio mútuo e depois em sindicatos (PAULA, 2009, p. 62).

Ou seja, aqueles movimentos de associativismo e cooperativismo que nutriam o surgimento dos sindicatos, verificado por Paul Singer (2009) como frutífero primeiro na Inglaterra e naqueles países que incorporaram intensamente a industrialização, revelou-se presente no Brasil no final do século XIX e início do XX. Inclusive, Amir de Paula (2009) verifica uma verdadeira aglutinação dos sindicados em áreas de maior industrialização, que no Brasil do início do século XX significou a concentração sindical em São Paulo e no Rio de Janeiro, então Distrito Federal. 
Outra convergência diria respeito à relação para com o comunismo, que assumiria a linha de frente destes movimentos. Isto remete ao que Mary Del Priore e Renato Venâncio (2006a) destacam como sendo crucial ao mantimento do discurso de seguridade nacional verificado mais tarde, no pós-1964, que dizia respeito "a maioria das entidades populares do campo [ser concebida] como expressão do movimento comunista internacional. Era necessário combatê-las em nome da seguridade nacional.” (PRIORE e VENÂNCIO, 2006a, p. 203).

Amir de Paula (2009) ressalta que toda aquela ausência estatal verificada desde o surgimento dos sindicatos, no final do século XIX e início do século XX, se transforma na década de 1930 “alterando as formas de relacionamento existentes até então entre as entidades sindicais" (PAULA, 2009, p. 60).

Compartilhamos da hipótese de que a Revolução de 1930, tendo como base uma maior centralização do poder, procurou limitar a escala de ação dos sindicatos, "adequando-os" a um modelo único oficial. Essa intervenção na forma de organização dessas entidades determinou a fragmentação de suas lutas, separando, por exemplo, sindicatos de uma mesma categoria pela sua base territorial. Ou seja, inibiu um maior contato entre as agremiações das áreas menos industrializadas com seus congêneres do Centro Sul do país (PAULA, 2009, p. 60).

Além das fragmentações entre os sindicados, concentrados em áreas industriais e também urbanas, havia outra muito evidente que se dava entre os sindicatos urbanos e aqueles outros rurais, que passaram a incluir também os trabalhadores rurais.

Anita Brumer (2002) interessa-se pelo estudo da previdência social brasileira por alguns motivos, a saber: por que ela revela a tardia inclusão dos trabalhadores rurais; pois demonstra a histórica ação estatal na concessão de benefícios a estes trabalhadores. Ao passo que no sindicalismo urbano se verificou a mobilização dos interessados e a criação de sindicados específicos a cada categoria. Neste sentido, ela analisa a forma como a previdência é deficitária "uma vez que o valor total das contribuições é inferior ao montante de benefícios, parece haver uma certa distribuição de rendas do setor urbano para o rural" (BRUMER, 2002, p. 51).

Mary Del Priore e Renato Venâncio (2006a) ressaltam que, a despeito do direito concedido à criação do sindicato especificamente rural, através do Decreto-Lei ${ }^{\circ} 7.038$ de 1944; em 1961, dezessete anos depois, “ainda não havia um só sindicato rural reconhecido 
pelo Ministério do Trabalho". Contudo, a década de 1960 parece marcar profundamente a história do sindicalismo brasileiro, que passou a ser encarado como força política, ou seja, "um segmento que poderia ser mobilizado para pressionar as elites" (DEL PRIORE e VENÂNCIO, 2006a, p. 204).

Ainda segundo Brumer (2002),

A partir da década de 1930, a vinculação à previdência social, com a cobertura de aposentadorias e pensões, começou a ser feita por categoria profissional, vindo a envolver quase a totalidade dos trabalhadores assalariados urbanos e grande parte dos autônomos. [...] A administração dos Institutos de aposentadorias e pensões, desde este período, passou a ser comandada pelo Estado, que escolhe e nomeia seus presidentes, além de definir o formato organizacional de todo o sistema de seguridade social, e a decidir o valor das contribuições dos indivíduos (montante a ser poupado) e onde aplicar os recursos extraídos da sociedade (BRUMER, 2002, p.54).

Esta autora destaca que essa década de 1960 foi marcada pela tentativa de estender a cobertura previdenciária aos trabalhadores rurais, mas não se efetivou por conta da insuficiência da própria legislação, o que Del Priore e Venâncio (2006a, p. 204) chamam de "direitos artificiais". A despeito de verificados casos de o salário de cortadores de cana-deaçúcar, por exemplo, sofrerem um aumento de $750 \%$ após a sindicalização (DEL PRIORE e VENÂNCIO, 2006a), Brumer (2002) salienta que

[...] com a aplicação do Estatuto do Trabalhador Rural [ETR] e graças aos esforços das associações de trabalhadores rurais, estendeu-se o pagamento do salário mínimo aos trabalhadores assalariados, o que teve pelo menos três efeitos: 1) desenvolvimento comercial em áreas onde havia grande número de trabalhadores rurais assalariados (como em Pernambuco, por exemplo), pois os trabalhadores aumentaram o consumo de produtos que antes lhes eram inacessíveis; 2) dispensa de trabalhadores rurais de muitas plantações, pois havia proprietários que administravam ineficientemente suas fazendas e não podiam enfrentar o pagamento do salário mínimo; 3) aumento do preço dos produtos agrícolas e transformação de muitos estabelecimentos agrícolas em fazendas de criação de gado, que requerem menor força de trabalho (BRUMER, 2002, p. 54).

Além dessas paradoxais influências do ETR, que serão mais bem discutidas no segundo capítulo, Mary Del Priore e Renato Venâncio (2006a) salientam ainda que neste cenário imbuído de repressão à esquerda e quando se atentou para a força política exercida 
pelos sindicatos, a partir do governo de Marechal Castelo Branco (1964-1967), o Estado passou a pensar a estrutura sindical rural sob novos moldes. Para tanto, e

[...] por meio de acordos com os Estados Unidos, foram concebidos centros sindicais e cursos de lideranças baseados em princípios conservadores e ministrados por membros da Igreja católica. Resultado: em 1971, o número de trabalhadores rurais sindicalizados era da ordem de um milhão; no final dessa mesma década essa cifra havia aumentado para seis milhões (DEL PRIORE e VENÂNCIO, 2006a, p. 205).

As participações da Igreja católica e do investimento de capital privado, apontados no trecho anterior, revelam-se enquanto elementos interessantes a ser incorporados ao longo dessa pesquisa. E, no caso da Igreja, ela exerceu um importante papel efetivo e ideológico na luta pelo assentamento Cafundão por se tratar de proprietária legal de tais terras.

Porquanto, e ratificando-se o caráter breve desta análise, o que se percebe é que o movimento sindical em áreas urbanas envereda-se por caminhos muito ligados ao perfil de pessoas que representa, com a criação de sindicatos específicos a cada categoria. Já em relação ao sindicalismo rural, depara-se com uma divisão evidente entre Empregadores e Trabalhadores. Anita Brumer (2002) destaca que o Decreto-Lei 789, de 27 de agosto de 1960,

[...] redefine, para fins de sindicalização, o significado de Empregador Rural e Trabalhador Rural, introduzindo o módulo rural como elemento diferenciador, restringindo a existência de um único sindicato, em cada município, para representar a mesma categoria profissional. Essa legislação viabilizou a regulamentação dos sindicatos rurais, dando impulso à organização sindical de trabalhadores rurais e de produtores/empregadores rurais no país (BRUMER, 2002, p. 55).

Isso faz com que coexista os Sindicatos Rurais e os Sindicatos de Trabalhadores Rurais. No caso do Cafundão, o Sindicato de Trabalhadores Rurais, que silenciou-se mediante o conflito, foi sobreposto pela atuação daquele outro que representa os trabalhadores ligados à atividade mineradora, que se destaca no município de Mariana-MG.

Só o sindicato METABASE... [os ajudou no conflito] $O$ nosso sindicato rural foi o que menos ajudou. [Eu: vocês são filiados ao sindicato rural?] Nós era. O meu pai já era lá... Quando en fiz o sindicato pra assumir tudo do meu pai, parece que ele já era desde 1966 por aí... 
(senhor Adão, assentado, tio do senhor Nilton, neto do Francisco da Cruz de Oliveira e último herdeiro vivo do Joaquim Silvério de Oliveira seu bisavô. Possui filhos criados na terra e casados no assentamento, avô de três netos, original das terras do Cafundão. Foi pai novamente no desenvolvimento desta pesquisa).

Aliás, questiona-se o porquê de estes elementos terem ocorrido da forma como se deu. É interessante se atentar para algo, que será trabalhado ao longo da pesquisa, que é para atividade principal deste assentamento, que reside na extração de uma rocha e o seu torneamento à confecção de panelas de pedra, a despeito de possuírem atividades agrícolas numa escala de consumo das próprias famílias. Estas diferenças sugerem uma relação, ainda que não proposital, com a própria mobilização do sindicato METABASE, e não o outro, apesar deste último - o de Trabalhadores Rurais, apesar de ele mencionar somente Sindicato Rural - ter sido apontado pelo senhor Adão como nosso.

Porquanto, Francisco da Cruz de Oliveira e Joaquim Silvério de Oliveira são nomes apontados sempre pelo senhor Adão como aqueles que justificam a legitimidade de sua luta pela terra para recompor o que Margarida Maria Moura (1978) chamaria de "patrimônio territorial", que diz respeito ao sentimento de ser herdeiro da terra, ou de herança, que se dá através de laços de parentesco ou doações feitas ainda em vida. Estes nomes serão mais bem trabalhados na apreensão das memórias da luta, ao longo do desenvolvimento da pesquisa.

Esse é um terreno que ficava aqui dentro desse sítio, aí passou para o meu pai [Francisco da Cruz de Oliveira]. O irmão dele não teve um filho doou o que ele tinha para o que estivesse precisando fazer. Então tem esse daqui também [documento] e você vai levar. Essa [terra] é que o moço pegou ali em cima, aquela parte, aonde que lá ficou, e entrou cá derrubou as casas, e eu tenho aqui a indenização pra poder ficar ciente o quê que aconteceu... [Eu: e vocês nunca receberam essa indenização?] ... Não! Aqui está falando neste documento aqui que iria procurar outro imóvel dele [M⿻. $M^{5}$, mas o imóvel dele ficou lá... Por que o que era dele não era aquele terreno, que é de Igreja, mas só que pra ele considerar que é pra mexer com nós, era dele (senhor Adão).

\footnotetext{
${ }^{5}$ Será explicado logo adiante o porquê de se referenciar esta citada pessoa como senhor M.
} 
Voltando aos confrontos, que também se fizeram presentes nas Atas de Reuniões Ordinárias e Extraordinárias da Câmara Municipal de Mariana ${ }^{6}$, precisamente o Livro 10 e intensamente entre os anos de 1990 a 1992. Nestas, se aponta o "problema da demanda por terreno" e a "solicitação que a casa [Câmara Municipal] intervenha na justiça". Consta também o registro da exposição do senhor Valcir Pereira Viana, membro do mencionado sindicado METABASE e então vice-presidente do Partido dos Trabalhadores - PT do município de Mariana.

Usou da palavra em nome do pessoal de Cafundão, o Sr. Valcir Pereira Viana, vice-presidente do Partido de Trabalhadores deste município que falou do M., que vem ameaçando os moradores do local, estando armado e o povo já está com suas terras prontas para o plantio. Esperando que a Câmara Municipal já requeira a desapropriação de terreno para sanar esta situação, embora M. continua ameaçando o povo. (ATA DA CÂMARA MUNICIPAL DE MARIANA, 12 DE NOVEMBRO DE 1990, LIVRO 10).

Esta mesma Ata, datada de 12 de novembro de 1990, prossegue com um testemunho de um advogado, chamado de Derly Pedro da Silva, que afirma que as Leis não se fazem presentes no município, e que a "polícia não toma conhecimento dos fatos degradantes que estão ocorrendo nesta cidade e nos distritos”. Essa afirmação incisiva contra a polícia ocorreu posteriormente a uma possível resposta do Delegado da Polícia para o problema do Cafundão, realizada na forma de carta que não foi anexada nem copiada na Ata datada de 29 de outubro de 1990, mas fora nela mencionada.

Prosseguindo ainda na Ata de 12 de novembro de 1990, foi criada uma Comissão Parlamentar de Inquérito (CPI) para apurar o que se passa nas terras do Cafundão, e uma Comissão de Direitos Humanos, compostas por vereadores, para acompanhar os depoimentos dos envolvidos na Delegacia de Polícia, ou seja, daqueles que são hoje assentados. Acusou-se ser essa uma "situação bastante delicada e perigosa", mas alguns vereadores "sustentaram as suas alegações em favor dos posseiros de Cafundão que ali residem há mais de cem anos”. Como também,

\footnotetext{
${ }^{6}$ Estas Atas estão arquivadas na Câmara Municipal de Mariana. Foi concedido o acesso, desde que a consulta se desse no interior da sala de arquivamento. Como não havia funcionário específico à curadoria de arquivos, a consulta mobilizou a atenção de uma secretária da Câmara que, a despeito de ter sido atenciosa, em alguns momentos revelava incômodo com a presença, já que ela também não poderia sair dessa sala, para não deixar uma pessoa estranha a este ambiente sozinha com os Livros.
} 
O vereador Geraldo Ramos Magalhães voltou a falar do Cafundão, acusando M., que é o principal causador do tumulto criado lá em Cachoeira do Brumado (Cafundão) [...] Em seguida, foi apresentada um requerimento assinado por todos os senhores vereadores, solicitando a remoção do Dr. Delegado de Polícia, em virtude do tumultuado caso de Cafundão (ATA DA CÂMARA MUNICIPAL DE MARIANA, 12 DE NOVEMBRO DE 1990, LIVRO 10).

As acusações de omissão não cessaram, por parte daqueles que poderiam intervir no conflito: partidos, polícia, políticos e a justiça. Esta CPI criada também não registrou nenhum produto na forma de relatório ou algo que tenha sido arquivado na Câmara, onde deveria constar.

Em 11 de maio de 1992, um representante do Partido dos Trabalhadores (PT) se faz presente na reunião da Câmara, para realizar "um relatório sobre a situação reinante no local denominado Cafundão" convidando a todos a comparecem para verificarem a vivacidade deste relatório. Travou-se uma série de declarações acerca da não-omissão e que essa questão deveria ser resolvida pela justiça. Assim como, depara-se com a leitura de um conflito que se estabeleceu entre vereadores, qual seja: um deles por ter publicizado o que estava acontecendo no Cafundão, em favor daqueles que são chamados de posseiros, e o outro por ter atacado a publicação que mencionava seu nome enquanto aquele que contribuía para omissão. Depois disso, não se verificou mais nenhuma menção ao caso do Cafundão, neste Livro 10.

[Eu: O que são esses quatro mil cruzeiros aqui (em um dos documentos a mim entregue pelo senhor Adão)...?] Isso é o senhor [Antônio Filomeno] que o meu avô trabalhou com ele, que tinha esse sítio... foi tudo herança dele... [Ele começa a apontar com o dedo os limites do terreno]... [Eu: Então, foi doação para o seu avô, que é] É, Francisco da Cruz de Oliveira. Este terreno aqui é como se fosse tudo dele. Então ai eu tenho aquele mapa lá, que mostra aquilo ali. [Refere-se a um mapa que o senhor Adão acusa ter sido feito comprovando os limites do sitio Cafundão, de forma que seriam maiores do que aqueles que hoje correspondem aos limites do assentamento]. [Eu: Estas terras aqui são as mesmas que hoje é o assentamento?] Era o sítio todo. [Eu: Entendi. Então hoje o assentamento está dentro do sítio e o sítio é maior que o assentamento? Então, essas terras aqui são suas por herança e vocês tiveram que ir pro INCRA pra reconhecer?] É, maior. Senão, estava no fórum, tudo na mão da justiça para indenizar o resto. Só que lá, o outro tem dinheiro [menciona o senhor M.], e veio com armamento pra saber se nós iríamos sair. Por que, se nós saíssemos, ele pulava pra dentro. (senhor Adão) 
E toda esta omissão prosseguiu. Há um processo interrompido disponível no sítio oficial do Tribunal de Justiça de Minas Gerais, sob a numeração única 001620287.1997.8.13.0400. Acusa-se somente que o processo foi aberto no ano de 2004, e que em 2009 foi feita a última alteração no mesmo. O réu possui o nome M. e os requerentes são aqueles que iniciaram o processo de reconhecimento das terras do Cafundão, e a maioria deles é hoje assentada de reforma agrária. Optou-se por não anexar o processo onde consta o nome completo do senhor M., por uma questão de não se ter ouvido ainda sua versão deste caso, e, portanto, não se tem autorização para publicá-lo.

Não há resultados deste processo, nem que o resultado é algo em aberto. Está simplesmente interrompido, sem demais justificativas. Requisitando saber melhor acerca disso, informou-se junto a membros do Conselho Nacional de Justiça (CNJ), com sede em Brasília-DF, que solicitou à Vara de Justiça de Mariana demais informações. Esta última se negou a repassar, requerendo que se esclareça o motivo pelo qual da abertura de algo já fechado. Até o momento da redação deste texto, esta manteve sua postura de não explicar o desenrolar do processo. Essa requisição do CNJ é algo que se acompanha por e-mail, e que não consta o nome da pesquisadora como requerente, registrado em Diário de Campo.

Sabe-se que o senhor M. frequentemente apontado como ocasionador do conflito, tanto pelos assentados, quanto conforme se verificou nas Atas da Câmara, é formado no curso de Psicologia, numa universidade federal mineira, desde 1980. Como percebido, vem desenvolvendo trabalhos em sua área ainda hoje. Não se entendeu como e o porquê, de fato, deste psicólogo estar envolvido neste caso específico das terras do Cafundão. O desenrolar do conflito poderia ser entendido se o processo não constasse estranhamente pela metade, no sítio oficial do Tribunal de Justiça de Minas Gerais. Não há sentenças e muito menos pistas acerca do que se considerou neste processo, e percebeu-se ser exatamente isso que motiva o senhor Adão a querer que esta história seja investigada e contada: o de estar preenchido por um sentimento que soa a ser àquele de indignação.

[Eu: Então aquela parte não entrou para o assentamento? - apontei em direção às terras onde morava o senhor M.]? Não, era ela que era pra por! Pra pagar a indenização. [Eu: então aquelas terras entraram de indenização pra vocês, por ele ter derrubado as casas, só que as terras não eram dele e não teve como converter em indenização?] Não. Mas, fala ai neste negócio que tinha que ser outro bem do M., mas o bem dele ficou lá né? Aqui fala do Antônio Mazzaropi, do José Maria da Rocha, Bernadete, e... [Eu: E aí depois saiu essas terras aqui mesmo como indenização, e aí vocês chamaram o INCRA pra reconhecer?] Não. 
Chamamos antes. Depois é que saiu do fórum isso ai. Isso já estava lá. Só que nós íamos lá, e pra nós não tinha.... Não, era do fulano! Aposto que a justiça diria que essas terras eram suas então você terá que pagar indenização pra eles. Mas, como, a justiça foi divina. Essa não falha! (senhor Adão)

Em suma, segundo o senhor Adão, o referido processo foi iniciado depois que o senhor M. passou a pressionar a saída daqueles que são hoje assentados, através de ameaças também físicas, inclusive com disparos de armas de fogo, e a queima de suas casas. As terras do próprio senhor M., que se localiza à cabeceira dos dois córregos que cortam o assentamento descendo a vertente, seriam convertidas em indenização, pelo dano provocado por ele a estas pessoas. O senhor Adão alega que a justiça requeria um bem do M., para fins de indenização, porém o único bem que ele possuía em seu nome seriam justamente as terras onde morava. Suspeita-se que isso que tenha obscurecido o andamento do processo e, aparentemente, feito com que o senhor M. saísse ileso.

Como se verá, as terras onde morava o senhor $\mathrm{M}$. foram revendidas à proprietária anterior, que é a Igreja, para serem destinadas para reforma agrária por meio da compra e venda. O juiz não as destinou como indenização, e não há o indicativo de outro imóvel ou compensação financeira. O tornar-se assentado significou além da resolução do conflito pela terra, um ponto final na tensão sem outras consequências à violência que se instaurou no Cafundão. Porquanto, este ponto final que foi dado se confirma através do Termo de Audiência $^{7}$ da $1^{\mathrm{a}}$ Instância, precedida pelo Poder Judiciário do Estado de Minas Gerais, referente ao processo 40098000571-6, que traz que os requerentes - que hoje são assentados desistem da penhora do imóvel do senhor M. que seria relativo à indenização pelo dano causado. Dano este relacionado à derrubada das casas que estes habitavam, no processo de tensão e disputa por terra. Curioso foi perceber que o senhor Adão não se atentou para o fato da desistência da penhora, demonstrando não ter entendido o porquê daquelas terras não terem sido reconvertidas enquanto indenização. Para ele, somente a justiça divina dará conta de punir o senhor M. por queimar as casas de sua família.

Percebe-se que para o senhor Adão a criação do assentamento ou o "chamar o INCRA" foi uma forma de cessar o conflito que estaria havendo entre vizinhos de gleba. $\mathrm{O}$

\footnotetext{
${ }^{7}$ Este Documento faz parte de uma série de outros que o senhor Adão entregou num envelope de papel pardo para que se compreendesse definitivamente esta história. Percebeu-se uma importância da escrita, ou do registro documental, como forma de comprovar suas memórias acerca da construção da luta. A este respeito irá melhor se explanar mais adiante.
} 
mencionado senhor M. teria um terreno localizado no topo da vertente, onde hoje se localiza também uma parte do mencionado loteamento Bela Ville. A causa do conflito seria a ambição do senhor M. em se apropriar de terras até onde sua vista alcança, num sentido de vertente a baixo, conforme apontou o senhor Adão. Por este motivo, é que parece que houve toda a pressão para que as famílias que lá residiam saíssem de tais terras. Conforme será verificado, esta questão de posse é um eixo de análise interessante para se apreender a história de luta pela terra do Cafundão.

Neste sentido, toda esta omissão verificada no caso das terras do Cafundão também foi verificada por diversos estudiosos e profissionais que buscam saber mais acerca dos mais vastos conflitos existentes em todo o país. Inclusive, vários filmes já foram produzidos, contribuindo para a divulgação do que ocorre em locais que nem sempre recebem a atenção necessária das entidades responsáveis pela promoção do bem-estar social. E quando divulgados, passam pelo crivo do que se quer presente na mídia, como verificou Patrícia Alves Ramiro (2010) em sua investigação acerca do tipo de cobertura feita pelo jornal Estado de São Paulo em relação à criminalização dos movimentos sociais.

Para citar alguns conflitos que foram registrados por obras cinematográficas, criadas através do trabalho de pessoas que investigaram, e contendo declarações de estudiosos e pesquisadores acerca dos conflitos, destaca-se: a) Fazenda Santa Elina localizada no município de Corumbiara no sul do Estado de Rondônia. Este conflito é conhecido como Massacre de Corumbiara ${ }^{8}$; b) Acampamento do Movimento dos Trabalhadores Rurais SemTerra (MST) chamado de Engenho Camarazal, localizado na Zona da Mata norte do Estado de Pernambuco99; c) as Ligas Camponesas, organização criada pelo Partido Comunista do Brasil, em Pernambuco $^{10}$; d) Massacre de sem-terra no município de Eldorado dos Carajás, sul do Pará, ficando conhecido como Massacre do Eldorado ${ }^{11}$; e) Conflito por terra mediante o avanço da plantação de cana, em áreas de proteção ambiental no oeste paulista, chamado de Pontal do Paranapanema ${ }^{12}$; f) Campanha de Contestado, conflito em torno da concessão de

\footnotetext{
${ }^{8}$ Sobre o Massacre de Corumbiara, indica-se: Corumbiara (Vincent Carelli, Brasil, 2009, 01h57 min); O Massacre de Corumbiara (TVT, Brasil, 15min); Corumbiara, nunca mais (Adécio Dias, Brasil, 1996, 01h10 min); Corumbiara: o massacre dos camponeses (Helena Angélica de Mesquita, Brasil, 1995).

${ }^{9}$ Sobre Camarazal: Armas não Atiram Rosas (Maria Luísa Mendonça e Thalles Gomes, Brasil, 2007, 14 min)

${ }^{10}$ Sobre as Ligas Camponesas: Memórias Clandestinas (Maria Thereza Azevedo, Brasil, 2007, 52 min)

${ }^{11}$ Sobre o Massacre do Eldorado de Carajás, indica-se: Escola Eldorado (Victor Lopes, Brasil, 2008, 13 min), Nas terras do bem virá (Alexandre Rampazzo, Brasil, 2007, 01h50 min)

${ }^{12}$ Sobre o Paranapanema, indica-se: Cana no Pontal? (Antonio Thomaz Júnior, Brasil , 2008, 25 min)
} 
terras para uma companhia de estrada de ferro estrangeira, no interior de Santa Catarina ${ }^{13}$; g) a primeira grande desocupação de terra improdutiva no Brasil, que ocorreu na Fazenda Annoni, no Rio Grande do Sul, num cenário de redemocratização do Brasil e início do MST (Movimento dos Trabalhadores Rurais Sem-Terra), no final da década de $80^{14}$.

Salienta-se que se escolheu não datar estes conflitos apontados, assim como não se poderia dizer quando começou o conflito pela terra do Cafundão. Geralmente, se escolhe as datas de maior confronto armado como marco ou data simbólica. Mas, e o contexto que fez com que se chegasse ao confronto armado? Quando é que poderia ter começado, inclusive, o embate psicológico da luta? Quando é que se teve anseio em lutar? Quando é que se reconheceu parte de uma luta? Quando é que a luta cotidiana de sobreviver numa terra, ou em qualquer local, sofre tensionamentos maiores a ponto de estabelecer o conflito físico? E a memória do conflito? E os processos de lembrar ou esquecer o conflito? E a permanência de anseios que motivaram as lutas e reformulações de outros novos motivos e anseios?

Datar um conflito, periodizando rigidamente, soou como destoante da ideia de que há memórias e identidades peculiares a cada luta que unem pessoas diferentes sob o signo de um mesmo confronto. E é isso que se estuda no Cafundão. E é isso que se acredita preencher todos estes conflitos apontados através dos filmes, e aqueles inúmeros outros vividos sem que se fale sobre ele. É por isso também que não se fala de datas, pois não se conhece a fundo a memória destas citadas e de outras inúmeras lutas, não se sabe de que forma ou em quem elas pulsam.

Se a luta é pulsante, as datas servem somente para marcar o período de maior confronto físico, e também de mortes. Ou servem ainda como marco simbólico de conquistas que se quer alçar a uma coletividade mnemônica. Mas há de se considerar também os contextos formadores das lutas, que Lygia Sigaud (2005) chama de sociogênese, e a forma como estes conflitos são armazenados, reproduzidos e silenciados através da memória, que é também movente.

Neste sentido, optou-se também por não reproduzir o número de mortes em cada conflito porque, primeiro, na maioria desses casos, trata-se de algo questionável, pois os números de desaparecidos apontados pelos seus pares não corresponde ao número divulgado

\footnotetext{
${ }^{13}$ Indica-se, sobre a Campanha do Contestado: Guerra dos Pelados (Sylvio Back, Brasil, 1970, 01h38 min)

${ }^{14}$ Sobre a ocupação da Fazenda Annoni, indica-se: Da Terra ao Sonho de Rose (DVD Duplo - Tetê Moraes, Brasil); O Sonho de Rose: dez anos depois (2000, $01 \mathrm{~h} 32 \mathrm{~min}$ ); Fruto da Terra (Tetê Moraes, Brasil, 2008,15 min)
} 
pela mídia ou por boletins oficiais. Como por exemplo, no caso do Massacre de Corumbiara onde as notícias oscilam entre doze ${ }^{15}$ e dezesseis ${ }^{16}$ ocupantes da Fazenda Santa Elina (município de Corumbiara, Rondônia) que foram mortos, dentre aqueles desaparecidos e as centenas de sobreviventes que passaram ou presenciaram torturas, assassinatos e tensões na madrugada do dia 09 de agosto de 1995, que se tornou marco dos tensionamentos que foram motivados por elementos geradores do conflito, e que permanecem vivos na memória de quem viveu, e em alguma medida lembrado por atores específicos, e desconhecido pela imensa maioria de brasileiros.

Isso leva ao segundo motivo que justifica não contabilizar estes corpos, que é o uso político destes números. Muitas vezes, o número de tombos, que é a expressão usada nestes filmes para a morte de um companheiro de luta, traduz a magnitude ou a crueldade de um conflito. O número de mortes acaba criando uma forma escalonada de dizer o quão desumano se tratou aquele conflito, e por isso também é que se diminui para amenizar, ou aumenta para chamar atenção.

Inclusive, segundo reportagem de Luciano Nascimento, da Agência Brasil: Empresa Brasil de Comunicação, de 24 de maio de 2013, foi lançado nesta data um livro que irá auxiliar a Comissão Nacional de Verdade (CNV) a reconhecer os casos de mortos e desaparecidos no campo brasileiro. O livro se chama Camponeses Mortos e Desaparecidos: Excluídos da Justiça de Transição, e irá abarcar principalmente o momento considerado como de transição política, que iria de 1964 a 1985, compreendendo o período de ditadura militar. O repórter Luciano Nascimento ainda menciona a Lei 9.140/1995 que reconhece que assassinatos ocorreram neste período de governo militar.

'É importante para os trabalhadores rurais, para os camponeses brasileiros recuperar essa história, porque muito dessa história ainda é atual e o estado tem a responsabilidade de apurar os crimes e, com a Comissão da Verdade, fazer com que isso seja colocado a limpo', disse o coordenador do projeto Direito à Memória e à Verdade, Gilney Viana, da Secretaria de Direitos Humanos da Presidência da República (SDH), que elaborou o estudo que resultou no livro em parceria com a Comissão Camponesa da Verdade.

De acordo com o livro, há mortes durante o regime militar e também durante o regime civil. Quatro pessoas foram assassinadas antes do golpe de abril de 1964; 756 foram mortas durante a ditadura (sendo 432 na abertura política

\footnotetext{
${ }^{15}$ Disponível em: http://www.brasildefato.com.br/node/17740. Acesso em 30 de janeiro de 2014.

16 Disponível em: http://amazonia.org.br/2013/09/mpfro-apoia-v\%C3\%ADtimas-do-massacre-de-corumbiara/ Acesso em: 30 de janeiro de 2014.
} 
após 1979); e 436 após março de 1985, na transição civil (governo Sarney). Segundo o documento, o aumento da violência no campo a partir da distensão e ao longo da chamada Nova República tem a ver com a organização política dos trabalhadores rurais (AGENCIA BRASIL, 2013) ${ }^{17}$.

Foi necessário criar uma Comissão Nacional da Verdade (CNV), a partir da Lei 12.528 de 18 de novembro de 2011 e instituída em 16 de maio de 2012, para "examinar e esclarecer as graves violações de direitos humanos" $" 18$ ocorridos no mencionado período ditatorial, e indo evidentemente antes e além dele. E através da Resolução nº5 de 05 de novembro de 2012, foi instituído "no âmbito da Comissão Nacional da Verdade, Grupo de Trabalho sobre violações de direitos humanos relacionadas à luta pela terra e contra populações indígenas, por motivações políticas"19, que é a Comissão Camponesa da Verdade (CCV), mencionada na reportagem. Esta Comissão

Tem como proposta acompanhar e subsidiar o trabalho da Comissão Nacional da Verdade de reconstrução da memória e verdade sobre a resistência camponesa no período de pesquisa abrangido pela Comissão (1946-1988) e é composta por representantes do Movimento dos Trabalhadores Sem Terra (MST), a Contag, Plataforma Dhesca, Comissão Pastoral da Terra e Movimento de Mulheres Camponesas em parceria com a Secretaria de Direitos Humanos (SDH). ${ }^{20}$

Ou seja, reconhece-se que mortes com motivações políticas ocorreram na história do Brasil, e foram até agora acobertadas. Este período caracteriza-se pela pressão política, que silenciou várias vozes e que apagou a memória da existência de vários corpos, relegando a eles a inexatidão de um desaparecimento. Porém, a ditadura não condensa os conflitos brasileiros num só período, numa só postura governamental, num só recorte de espaço-tempo. Há historicidades e latências dos conflitos, grandemente relacionadas à desigualdade de tratamento no acesso a terra e na história de construção do espaço brasileiro.

\footnotetext{
17 Disponível em: http://agenciabrasil.ebc.com.br/noticia/2013-05-24/livro-apresenta-1200-casos-decamponeses-mortos-e-desaparecidos-na-ditadura-militar. Acesso em: 15 de janeiro de 2014.

18 Texto da Lei, disponível em: https://www.planalto.gov.br/ccivil_03/_ato2011-2014/2011/lei/112528.htm. Acesso em: 15 de janeiro de 2014.

19 Texto da Resolução n5, que cria a Comissão Camponesa da Verdade. Disponível em: http://www.cnv.gov.br/images/pdf/resolucao_05_051112.pdf. acesso em: 15 de janeiro de 2014.

Retirado do sítio oficial da Comissão Nacional da Verdade, disponível no seguinte endereço: http://www.cnv.gov.br/index.php/outros-destaques/310-cnv-e-comissao-camponesa-da-verdade-debatem-viol acoes-de-dh-no-campo. Acesso em: 15 de janeiro de 2014.
} 
Até o momento, percebe-se um tangenciamento entre certos atores citados pelos assentados e aqueles outros encontrados na literatura abrangente acerca da questão da terra. Não se trata dos mesmos atores, evidentemente, por que as instituições são compostas por pessoas que constroem suas diretrizes. Fala-se das instituições Estado, Partido Político, Sindicato, Igreja, Família, e certos atores sempre atrelados ao dinheiro e ao poder no local onde atua.

Tais instituições, por vezes, atuam de alguma forma nos mais diversos cenários de conflitos acontecidos ou latentes, espalhados pelo país. Contudo, o tangenciamento de ações e decisões tomadas, ou silenciadas, em cada conflito que possa ser estudado parece revelar uma ideologia que se atravessa àquilo que se denomina como historicidade ou permanência da concentração de terras. Por esse motivo, é que se inclina a assumir aqui uma postura de entender a distribuição e o acesso estruturalmente desigual às terras como algo politicamente escolhido para ser assim, reprodutível. Não se trata de algo que somente respalda sobre as formas de construção do espaço hoje percebidas: é o próprio espaço brasileiro sendo estrategicamente construído para atender fins específicos.

O olhar sobre estas Instituições e sobre outros conflitos mais pontuais parecem fornecer subsídios para se entender como se rearranjaram no caso do Cafundão. Destaca-se que não se pretende construir aqui uma história do Cafundão em seu sentido verídico e coeso, enquanto A História. A pretensão reside na inquirição por elementos que possam pertencer à gênese social do assentamento através das memórias dos assentados. Como também, não se pretende apontar certas ações tomadas por uma instituição, em detrimento de outra, numa espécie de conceber os assentados como vítimas de uma trama elaborada pelos atores que eles mesmos apontam como pertencente à história de luta pela terra. Irá se tentar perceber os entrecruzamentos de ações para com aqueles verificados por autores que serão chamados a contribuírem ao debate com exemplificações.

As terras do Cafundão não são somente uma peça de um quebra-cabeça que descreva a questão da terra: concebe-se aqui a história dos assentados enquanto expressão de contextos tensos que o envolve e que adquire sentidos, no plural, percebidas ao aproximar-se das próprias narrativas compostas por imaginários e por vivências destes. A história do assentamento de reforma agrária Cafundão se inscreve na história da desigualdade do acesso a terras no Brasil. 


\subsection{Historicidade da desigualdade de terras no Brasil}

Autores, tais como Moisés Vinhas (1972), Caio Prado Junior (1981), José Eli da Veiga (2003a, 2003b), José Graziano da Silva (2001) e inúmeros outros, denunciam a questão de terras no Brasil, chamando atenção para os elementos como a má distribuição e o acesso desigual. Estes elementos compõem o que se chama aqui de historicidade da desigualdade de terras, para além de concebê-las somente em seu significado produtivo. Assumir que há significâncias e significados que emolduram a questão da terra fornece subsídios para se compreender certas motivações de lutas que se dão pela terra, na terra e por consequência da terra.

Além disso, é preciso esclarecer que estas terras aqui mencionadas não se circunscrevem em uma área que vem para estabelecer uma oposição binária àquelas terras, e também modos de vidas, que se dão em espaços específicos conhecidos como cidades. Desta forma, não se quer aqui mencionar as disputas que se dão num espaço ora chamado de agrário, ora de rural, em detrimento das análises daquele chamado ora de urbano, ora de citadino. Compreende-se que a historicidade do acesso a terra perpassa todas as formas de construção, apropriação e representação do espaço, pois está intrincada à história de construção do próprio país, sejam estas formas conceituadas como urbanas ou como rurais.

Aliás, essa discussão merece maiores reflexões acerca do que se concebe como rural e urbano. Ela já está sendo empreendida em termos de índices e estatísticas como fizera José Eli da Veiga (2003a), ou como são incorporados por imaginários ou descrevem modos de vida, tal como reflete Maria José Carneiro (1998). Convém destacar que interessante seria compreender de que forma estas imprecisas concepções contribuem para a formulação de ideários e de políticas ao longo da história de construção do país, já que as concepções de urbano e de rural certamente vem se movimentando com o mundo que reformula seus significados. Adquirem, portanto, ressignificações para além de ser somente dicotômicos, como apontou Pitirim Sorokin et al (1986), ou de se configurarem enquanto gradações num continuum existente entre os pares de opostos urbano e rural, conforme defende Aldo Solari (2006). Contudo, este debate amplo não se incorpora ao escopo dessa pesquisa.

Porquanto, estas historicidades se expressam em políticas de gestão do território ou em formas rígidas de percebê-lo hoje, conforme demonstram Mary Del Priore e Renato Venâncio (2006a, p. 203) em Uma História da Vida Rural no Brasil. Estes autores contribuem para a 
noção de historicidade a partir da ideia de permanências e rupturas. Segundo os autores, "a complexidade inerente à vida social implica quase sempre que projetos de rupturas convivam com permanências de períodos anteriores - principalmente quando essas permanências dizem respeito à forma como hierarquias sociais e a riqueza coletiva são estruturadas e compartilhadas". Ainda segundo estes autores, não se rompe com o passado apenas com decisões de grupos específicos ou vontades individuais. É por isso que a história da vida rural brasileira é fomentada por processos e por decisões tomadas ao longo dos espaços-tempos de construção do Brasil.

Neste sentido, estes autores traçam um panorama entre os movimentos populares no campo, o que inclui aqueles institucionalizados ou sindicalizados, com os discursos de seguridade nacional, que os relacionava a movimentos comunistas internacionais. Portanto, tais movimentos passaram a ser concebidos com uma conotação pejorativa no imaginário social, criado pelo próprio discurso do Estado. E destaca também que aquilo concebido como problema rural, grandemente relacionado à historicidade no acesso e posse da terra, foi diversamente tratado conforme épocas e grupos de atores específicos. Por exemplo, posteriormente ao período de 1964, quando estes autores destacam que o termo reforma agrária entra no cenário político ancorado pelo Estatuto da Terra ${ }^{21}$,

O problema rural, quando detectado, consistia numa questão técnica a ser solucionada por especialistas e não por políticos. Tal perspectiva teve dois efeitos primordiais sobre nossa história agrária. Um deles incidiu sobre os referidos movimentos sociais, e o outro diz respeito ao esforço de renovação técnico-científica da agropecuária brasileira (DEL PRIORE e VENÂNCIO, 2006a, p. 203).

Essa forma de encarar o problema rural foi primordial para sua apreensão e tratamento ao longo da história recente do país. É possível perceber estas questões, por exemplo, através das jurisdições no que concerne à questão da terra brasileira. Optou-se por se fazer uma espécie de revisão da jurisprudência agrária no segundo capítulo, para correlacioná-la à história jurídica de criação do assentamento de reforma agrária trabalhada no terceiro capítulo.

Porquanto, antes, é preciso que se compreenda a amplitude da questão da terra sendo formulada desde os momentos de colonialidade sobre o qual se inventou o território e o povo

\footnotetext{
${ }^{21}$ Refere-se à Lei 4.504, de 30 de novembro de 1964.
} 
brasileiro, com suas matrizes indígenas, europeias e, mais tarde, africanas. Por isso, concordase com Gerd Sparoveck (2003, p. 05) para quem "a concentração da posse da terra no Brasil tem suas origens na época do descobrimento". E, por isto, para Ângela Mendes de Almeida (2000), não se trata de escândalo o incrível e cumulativo desequilíbrio da estrutura fundiária, se dando sempre em favor do latifúndio.

Análise que pode ser entendida, também, a partir de uma leitura da ideologia espacial que funda um Estado nacional pautado na integração de um território visto, paradoxalmente, de forma desagregada do ponto de vista social e, ao mesmo tempo, que pôs em comunhão as elites agrárias e as elites urbanas, em distintos momentos da história brasileira (COSTA e SUZUKI, 2012). Em outras palavras, Everaldo Costa e Júlio Suzuki (2012) discutem sobre a ideologia espacial, pautada nos ideais de progresso, modernização e integração territorial. Tais ideais extrapolam o terreno do discurso e se impregnam na construção do espaço brasileiro. Atuam como influências, portanto, para a edificação de uma nação grandemente baseada numa produção cultural de elites, sustentada por símbolos que ratificam-se e se impõem como uma voz sobressalente nesta construção. O que os autores também denominam de variantes estéticas.

Deve-se considerar, preliminarmente, a escassez de análises que relacionam a consolidação do poder do Estado a suas variantes estéticas, elementos substanciais da sustentação da própria administração. Como estratégia, essas variantes estéticas são favorecedoras de uma ideologia espacial necessária não apenas para adjetivar, mas para dar sentido histórico e identitário a um Estado Nacional (COSTA e SUZUKI, 2012, p. 02, grifos dos autores).

Esta voz sobressalente que é aquela das elites não inibe a existência de outras vozes, relacionadas àquelas silenciadas ou segregadas por esta relação antagônica que se estabelece no território brasileiro. A relação de antagonismo diria respeito ao Estado que se administra e que se sustenta através de uma ideologia, que é a espacial, como também à substância estatal pautada na ideia de povo brasileiro, com sua heterogeneidade, vivacidade, identidade e memória plurais. Relação expressa por Costa e Suzuki (2012) através, por exemplo, da patrimonialização de cidades e do enaltecimento da arte barroca, como ocorreu com a cidade de Mariana, onde se localiza o assentamento Cafundão, que é uma cidade que emerge como símbolo da cultura nacional ao espaço-tempo em que foi construída. Esse movimento 
negligenciou os reais protagonistas (negros e índios) da formação do território e "proprietários" das terras no Brasil, como avaliam os autores.

Contudo, estar a favor do latifúndio, em comunhão com elites, se constituiria num eixo estratégico sobre o qual vem se dando a construção do espaço brasileiro, conforme denunciam alguns autores. Por exemplo, segundo Caio Prado Jr (1981, p.22)

Os grandes proprietários e fazendeiros, lavradores embora, são antes de tudo homens de negócio para quem a utilização da terra constitui um negócio como outro qualquer [...] do outro lado, para os trabalhadores rurais, para a massa camponesa de proprietários ou não, a terra e as atividades que nela se exercem constituem a única fonte de subsistência para eles acessível. Confundindo na análise da questão agrária situações tão distintas, não se pode evidentemente ir muito longe (PRADO JR, 1981, p. 22).

Esta análise da questão agrária brasileira foi percebida por José Eli da Veiga (2003b) como longe de parecer obsoleta, mesmo decorrido quase meio século.

Haverá nessas reflexões alguma coisa que não esteja obsoleta mais de 40 anos depois? Infelizmente sim. É chocante a atualidade dos principais artigos. Basta que se compare sua análise do Recenseamento de 1950, com as conclusões que se pode extrair do último Censo Agropecuário, de 1955/6. No Brasil foi a grande exploração agromercantil, de base territorial necessariamente extensa, que figurou no centro das atividades rurais na generalidade de suas regiões e zonas geoeconômicas. E foi em função desse "setor principal" que se constituiu, se manteve e evoluiu o outro "setor secundário" das atividades rurais (VEIGA, 2003b, p. 117- 118).

José Eli da Veiga (2003b) esclarece ainda que o setor principal corresponderia àquele alinhado com as atividades agroexportadoras, e o setor secundário se apresentaria de duas formas: a primeira se constituiria por trabalhadores empregados da grande exploração; e o segundo, seria formado pelos pequenos produtores, através de atividade autônoma em terras próprias ou arrendadas. Este autor refere-se a essa estrutura formada a partir da divisão entre os setores primário e secundário de "caráter bimodal da estrutura agrária brasileira" (VEIGA, 2003b, p. 117). Como forma de expressar o quão atual é a estrutura agrária que se dá através desse bimodalismo, José Eli da Veiga (2003b) ainda destaca:

Olhando para o instantâneo de 1950, Caio Prado Jr. ressaltava que o "setor principal" da grande exploração detinha $75 \%$ da área total e dispunha de 
cinco milhões de trabalhadores rurais, entre assalariados e parceiros, empregados a serviço alheio. $\mathrm{O}$ "setor secundário" era formado por grande parte desses trabalhadores residentes em grandes fazendas, mais uma infinidade de famílias que tocavam pequenos e médios estabelecimentos, amontoando-se no quarto restante da área total e ocupando quase sempre as manchas de solo de pior qualidade.

O instantâneo tirado em 1995/6 mostrou que 785 mil estabelecimentos patronais do "setor principal" ocupavam $63 \%$ da área total e dispunham de quatro milhões de trabalhadores. O "setor secundário" era formado pela diminuta parte desses empregados que ainda residiam em fazendas, mais 13 milhões de pessoas que viviam em 4 milhões de pequenos e médios estabelecimentos, amontoando-se nos restantes $37 \%$ da área total (VEIGA, 2003, p.119).

Ou seja, estruturalmente, pouca coisa mudou em mais de quarenta anos de análise. E isto possui explicação também através da face atrativa que a desigualdade agrária possui. Ângela Mendes de Almeida (2000) destacou muito bem o porquê de existência de Muita terra e pouco dono.

[...] A pequena propriedade seria coisa do passado, ultrapassada, sendo que a incrível desigualdade da estrutura fundiária constituiria um pré-requisito importante que o Brasil já teria para entrar na modernidade agrícola. Nesse aspecto, ao contrário de outros em que o neoliberalismo argumentava ter que superar obstáculos e entraves à modernidade, o país já estaria - subentendese, desde sempre, desde a instalação dos portugueses - preparado para receber a grande propriedade agrícola mecanizada. (ALMEIDA, 2000, p. 30)

Em outras palavras, reside nisso um acumulado de escolhas políticas não exclusivamente feitas por quem estivesse na linha de frente do país, que envolve também aquelas outras instituições anteriormente apontadas, e que se incorporam na estratégia de construção do espaço a ponto de outras formas possíveis, senão essa do bimodalismo, soar como utopias ${ }^{22}$. Por esse motivo, escolheu-se que o segundo capítulo trouxesse uma revisão da Jurisprudência agrária e correlata, para se perceber de que forma estas escolhas foram se incorporando no discurso jurídico na forma de leis, decretos e resoluções.

\footnotetext{
22 "Creio que poderíamos arriscar uma definição geral de utopia, válida para a linguagem ordinária, e que se resumiria na noção de imaginação de um mundo perfeito social e politicamente, mas, por isso, impraticável. [...] No caso do conceito de utopia, o caráter propositivo é radicalizado na medida em que o termo quer dizer de algo que não existe previamente; a utopia não representa algo que lhe é exterior. A mobilização por tal ou qual ator (ou autor) de um conceito complexo como o de utopia, ao mesmo tempo que se faz no interior de uma determinada perspectiva de mundo, resulta numa arma ou ferramenta na luta por uma posição no debate, na produção de alianças, na desqualificação dos seus adversários" (JASMIN, 2008, p. 37).
} 
Neste sentido, Graziano da Silva (2001) separa a questão agrária e a questão agrícola para que se elucidem, a partir de um escopo teórico, os processos que envolvem a questão da terra brasileira, como única questão. "Essa separação entre questão agrária e questão agrícola é apenas um recurso analítico. É evidente que na realidade objetiva dos fatos não se pode separar coisas em compartimentos estanques" (SILVA, 2001, p. 10). Para esse autor, há tomadas de decisão complexas que tendem a priorizar a questão agrícola, em detrimento da questão agrária, e que se operam no campo brasileiro, dando essa forma estrutura-bimodal, percebida por José Eli da Veiga (2003b).

Para Graziano da Silva (2001),

\begin{abstract}
A questão agrícola diz respeito aos aspectos ligados às mudanças na produção em si mesma: o que se produz, onde se produz e quanto se produz. Já a questão agrária está ligada às transformações nas relações de produção: como se produz, de que forma se produz.

No equacionamento da questão agrícola as variáveis importantes são as quantidades e os preços dos bens produzidos. Os principais indicadores da questão agrária são outros: a maneira como se organiza o trabalho e a produção; o nível de renda e de emprego dos trabalhadores rurais; a produtividade das pessoas ocupadas no campo, etc. (SILVA, 2001, p. 11).
\end{abstract}

Ou seja, a questão agrícola faz referência à dinâmica da produção, incluindo a otimização dos processos, ampliação dos rendimentos, logística de distribuição, e o que se produz. Esta questão incorporou facilmente as tendências apontadas por Ângela Mendes de Almeida (2000) que se relaciona à mecanização da agricultura. Por outro lado, a questão agrária seria mais ampla, relacionada às condições de vida no campo, à estrutura social que dá suporte para a produção, ao nível de renda e emprego dos trabalhadores, às mudanças nas tecnologias e ao impacto que isso traz às comunidades.

Essa diferença de tratamento também foi percebida por Ângela Mendes Almeida (2000) na composição ministerial brasileira, demonstrando que tal diferença extrapola os fins analíticos e se incrusta na construção do espaço brasileiro. Esta autora chama atenção para uma expressão importante da diferença de tratamento dado pelo governo brasileiro às questões agrária e agrícola, que reside na existência de dois Ministérios, a saber o Ministério do Desenvolvimento Agrário (MDA) e o Ministério da Agricultura, esse último recebe desde 2001 o nome de Ministério da Agricultura, Pecuária e Abastecimento (MAPA). Segundo esta autora, "a dualidade de intenções do governo em relação ao tratamento da política agrícola 
está expressa na existência de dois Ministérios”(ALMEIDA, 2000, p.29-30).

Salienta ainda que as questões consideradas, digam-se, mais sociais e relacionadas ao pequeno agricultor estão alojadas no MDA, enquanto que aquelas outras ligadas ao Complexo Agroindústria $^{23}$ estaria ancorada no MAPA. Cabendo salientar aqui também outra questão não apontada por esta referida autora, mas que cabe menção: o Instituto Nacional de Colonização e Reforma Agrária - INCRA estaria ancorado com sua função eminentemente social no MDA, enquanto que a Empresa de Assistência Técnica e Extensão Rural - EMATER que possuem seus escritórios estaduais são vinculados ao MAPA, até por desempenhar funções ligadas à assistência técnica de assentados de reforma agrária e de demais agricultores, sendo estes considerados agricultores familiares ou não.

Será importante evidenciar, a despeito de a EMATER estar alojada no MAPA, que o escritório local da EMATER-Mariana desempenha um papel importante à consolidação do Projeto de Assentamento Cafundão. Contudo, trata-se, segundo indagações com funcionários que nela trabalham, de iniciativas praticamente individuais, dada a falta de recursos convergidos a esta instituição.

Percebe-se que

Essa organização ministerial mostra que a separação entre a questão agrária e a agrícola está internalizada nos pressupostos que orientam o planejamento e as intervenções no campo brasileiro. As estratégias de desenvolvimento econômico, ampliação da produção, aumento da competitividade e lucratividade do setor agrícola encontram-se desconectadas, ideológica e fisicamente, das estratégias de promoção de qualidade de vida, dignidade e cidadania para a população que vive no campo. Temas como a reforma agrária e a agricultura familiar surgem como anexos do sistema agrícola brasileiro, não figurando entre as formas de organização que comandariam o processo de desenvolvimento. Esse tratamento diferenciado certamente encontra-se no cerne das tão graves desigualdades hoje percebidas no campo (RÚBIO, 2012, p. 52).

Esta expressão do diferenciado tratamento fomenta o que se chama de historicidade da concentração de terras no Brasil ${ }^{24}$ que dá sentido de ser a uma política de assentamento de

\footnotetext{
${ }^{23}$ Termo aqui utilizado a partir do uso e da apropriação que Martins (2006) que considera que a Agricultura, em seu sentido amplo, não poderia mais se resumir a um setor em separado ao de Serviços e o Industrial. Considera Complexo Agroindustria através da incorporação de outros determinantes em sua dinâmica. Desta forma, o desenvolvimento agrícola não advém somente da mecanização, seria consequente das relações interindustriais, submetendo-se, por vezes, ao próprio capital industrial.

${ }^{24}$ O Censo Agropecuário de 2006 (IBGE, 2006) revela que a concentração de terras aumentou nos últimos 10 anos - em relação ao estudo publicado em 1996 -, com base no aumento do índice Gini para 0,872, quando em
} 
reforma agrária, enquanto medida mitigadora de mal-estares ocasionados por este bimodalismo. Para Mary Del Priore e Renato Venâncio (2006b, p. 191), não há nada de mais falso do que a impressão de que "o Brasil, há quinhentos anos, discute a reforma agrária sem, contudo, conseguir chegar a uma solução ou mesmo a um mínimo de consenso". Para estes autores, a expressão reforma agrária foi construída sob uma base social que reclama por reformas, não significando com isso que antes dela entrar no cenário político a necessidade de reforma já não era algo exponente.

Essa tentativa de retomar a dimensão social da expressão reforma agrária é necessária ao entendimento de que ela pode significar anseios vastos, percebidos pelos autores Mary Del Priore e Renato Venâncio (2006b) ao longo da história brasileira. Por exemplo, quando acusam a ambiguidade de ela referir-se tanto a mudanças no que chamam de estrutura rural, quanto a posturas de incentivo estatal à agricultura. Em outras palavras, ela pode fomentar elementos destoantes pertencentes tanto à questão agrária, como à questão agrícola. "Recorria-se à expressão não só para justificar a distribuição de terras, como também para se defender a concessão de crédito agrícola, isenção fiscal, recuperação de áreas específicas, ocupação de fronteiras ou promoção da assistência a pequenos agricultores" (DEL PRIORE e VENÂNCIO, 2006b, p. 199).

Percebe-se, portanto, que a contexto fundiário desigual brasileiro se expressa também no Cafundão, que emerge enquanto território de luta à defesa do lugar - que possui memória, vínculos, saberes e vidas ligadas a esta terra. Porquanto, no segundo capítulo, será realizada uma revisão da jurisprudência para que se corporifique o que se entende aqui como a questão da terra, assim como para que se contextualize a política de criação de assentamento de reforma agrária neste cenário brasileiro historicamente desigual. Pela extensão, e pela complexidade, elenca-se marcos jurisdicionais a fim de contextualizar o surgimento da política de reforma agrária que cria a identificação que se pesquisa que é o ser-assentado. Por este motivo, é que o terceiro e quarto capítulo estarão dedicados ao diálogo entre a história jurídica de criação do assentamento Cafundão se entrecruzando com imaginários e memórias dos assentados acerca da luta.

1985 era de 0,857 e em 1995 de 0,856. È importante lembrar que quando mais próximo de 1 (um) maior a concentração de terras ou desigualdade fundiária. Disponível em: http://www.ibge.gov.br/home/estatistic a/economia/agropecuaria/censoagro/2006/agropecuario.pdf. Acesso em: 20 de janeiro de 2014. 


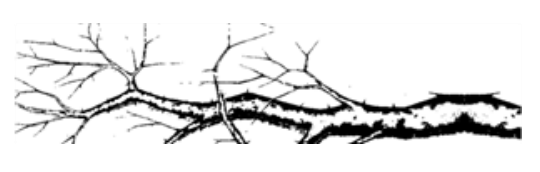

\title{
Capítulo 02:
}

\section{A política de reforma agráría e o cenário fundiário brasileiro.}

\begin{abstract}
"Aquilo que revelo / e o maís que segue oculto / em vítreo alçapões / são notícias humanas, / simples estar no mundo, e bríncos de palavra, um não-estar-estando, / mas de tal jeito urdidos o jogo e a confissão / que nem distíngo eu mesmo / o vivido e o inventado". (Carlos Drummond de Andrade).
\end{abstract}

\subsection{Elucidações II:}

[...] e avistou-se a primeira casa.

Vê-se tijolos acinzentados, não recobertos por reboco. Paredes, e os quadrados das janelas onde elas deveriam estar. Ausência de telhado, que revela o prolongamento da mata para o interior das paredes. Descobriu-se depois se tratar do local onde já se tentou construir uma igreja, uma sala de aula, um local onde mulheres teciam sisal na confecção de tapetes, com técnicas de coloração adquiridas através de curso da EMATER. E, agora, era um local onde se armazenam blocos de uma rocha também cinzenta, encostados em duas das paredes.

Uma nuvem de pó, que saía da parte da frente desta incompleta edificação, fez com que se continuasse o caminho descendente, em direção à nuvem, que escondia um portão de entrada. 
Figura 12: Visão do cômodo usado como local onde se armazena, em sua parte externa, os blocos de esteatito a serem torneados para confecção de panelas. Anteriormente, algumas tentativas de dar uso coletivo a este cômodo foram empreendidas: a primeira foi a ideia de possuir uma igreja local, mas que não se desenvolveu; posteriormente funcionou como sala de aula, mas por questão (de ausência) política não se consolidou; transformou-se num local à confecção de artesanatos, principalmente tapetes, em sisal, mas que não houve continuidade por questões que serão expostas mais adiante. Hoje, trata-se de um local que no desejo do senhor Adão haverá de ser um espaço de encontro, discussão, reflexão e confraternização do assentamento. Este cômodo é repartido entre dois banheiros, feminino e masculino, uma pequena cozinha, e uma sala de mais ou menos $20 \mathrm{~m}^{2}$. Acervo de pesquisa (2013).

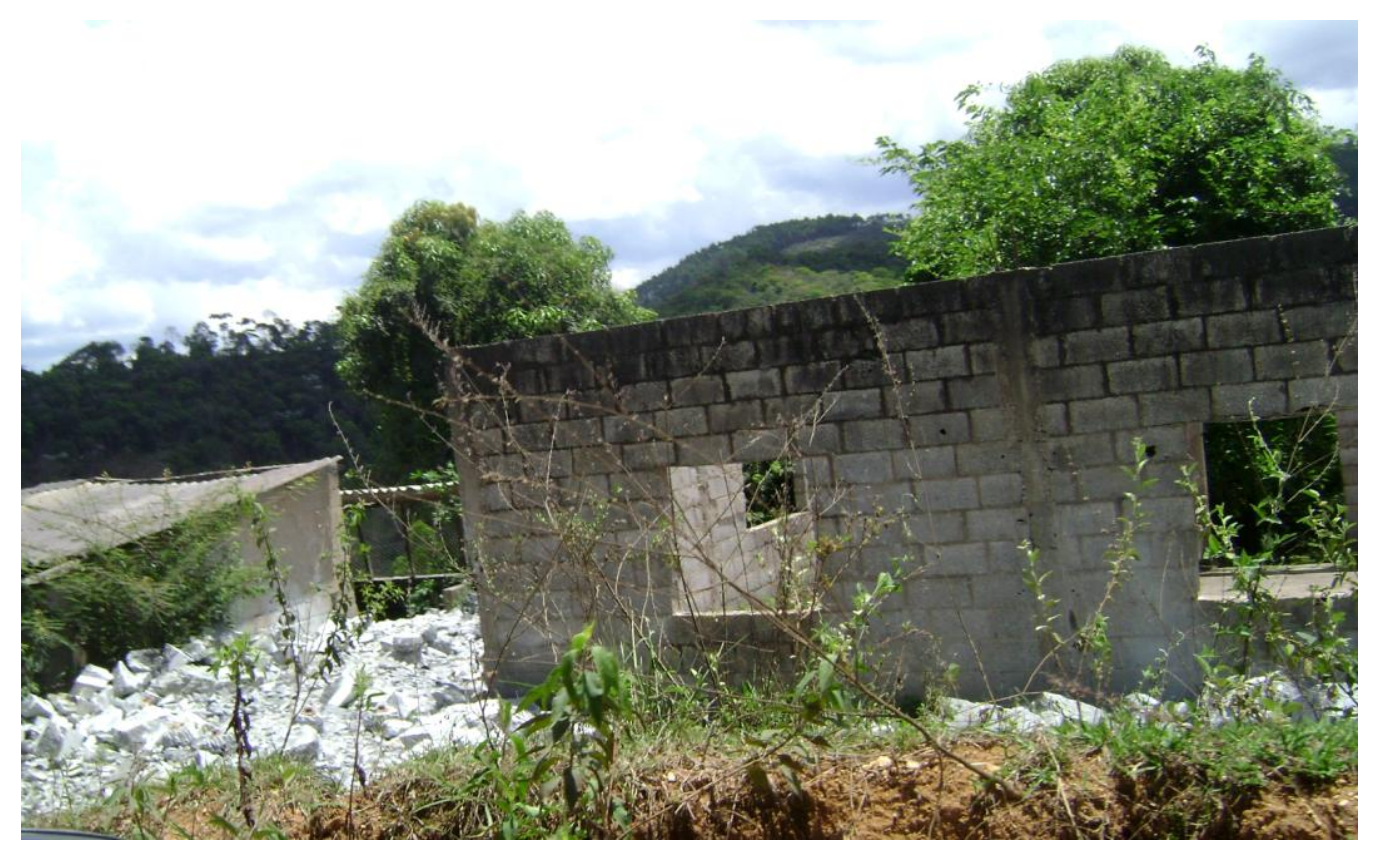

Figura 13: Visão interna do espaço coletivo, sem telhado, janelas, portas, e com a vegetação que adentra. Aos fundos, vê-se uma plantação de eucalipto que se localizam em terras paralelas ao assentamento, com limites que vão desta estrada de acesso até à estrada de leva à sede. Acervo de pesquisa (2014).

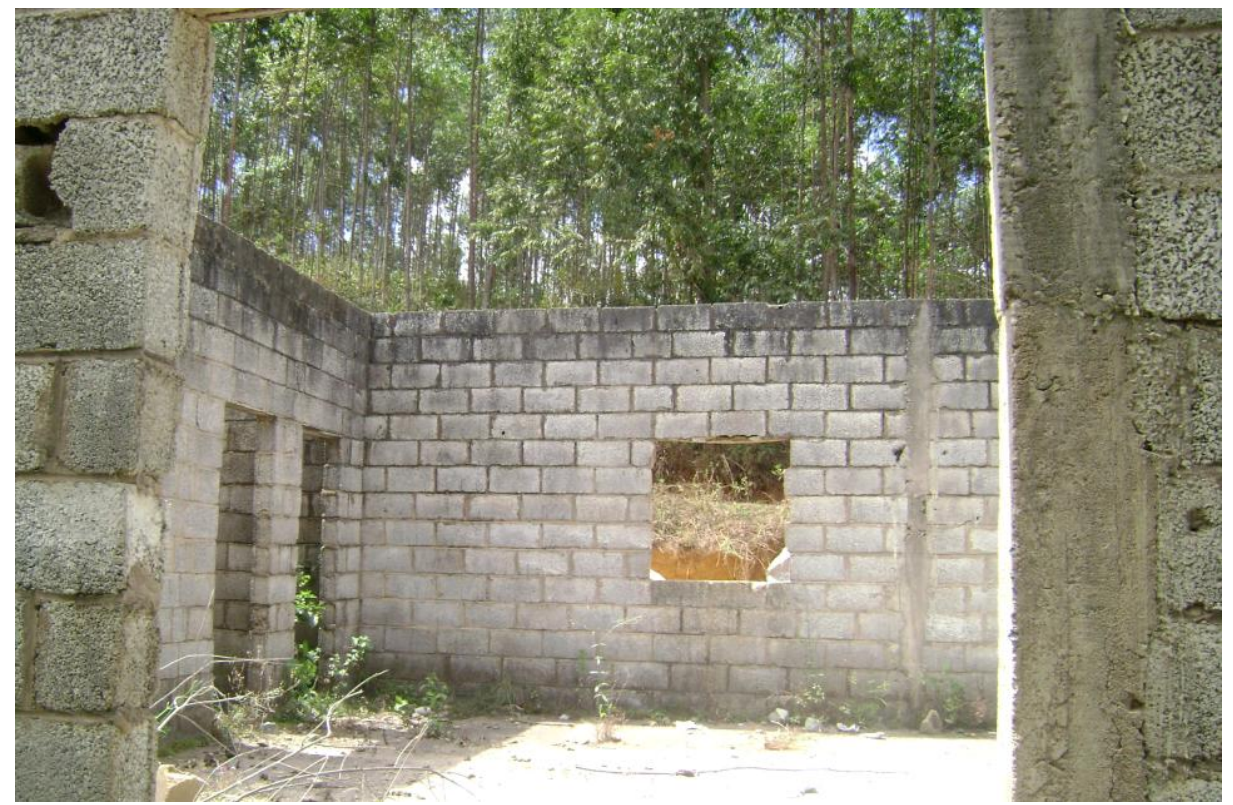


Trata-se de um galpão, de onde saiu um senhor com botinas, calça comprida, camisa com rastro de pó, e um boné onde constava o escrito CONTAG, que é a sigla para Confederação Nacional dos Trabalhadores na Agricultura. Descobriu-se depois que o boné foi ganho numa feira nacional de exposição de produtos oriundos de assentamentos de reforma agrária, que ocorreu em Brasília, no ano de 2009. Senhor Nilton é o seu nome.

Figura 14: Senhor Nilton na confecção de panela, no interior do galpão. Acervo de pesquisa (2013).

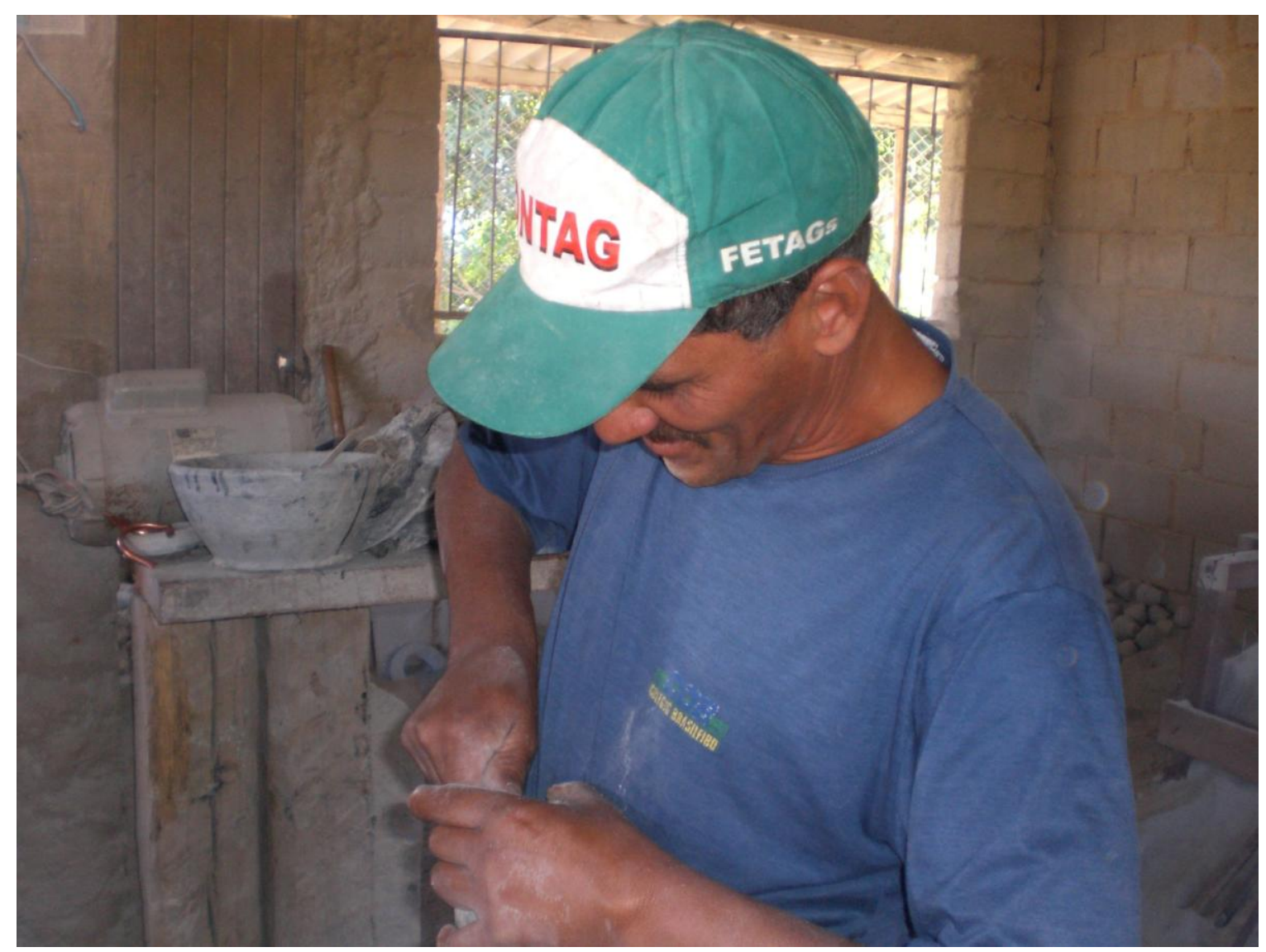

Ainda lá dentro do galpão, agachado no canto esquerdo de uma parede, colando puxadores em tampas de panelas de pedra, estava o tio do senhor Nilton, o seu nome é Adão e é o ultimo herdeiro de Francisco da Cruz de Oliveira.

O senhor Nilton revelou-se como aquele mais despojado, no sentido de ser aquele que recebe o de fora, tem fala simples, rica, e alta. Risonho, sabe prender a atenção, muitas vezes uma atenção relacionada à venda de panelas. Contador de causo, casos. Articula bem as ideias. Soube muito bem do que se tratava quando, nesta ocasião, falou-se que o interesse por 
suas histórias de luta pelo Cafundão residia no trabalho desenvolvido no mestrado. Disse: vai dar uma bonita história e você vai conseguir realizar seu trabalho.

Morou em São Paulo, trabalhou numa metalúrgica. Presenciou uma vida longe desta terra que nasceu, ainda que por alguns poucos anos. Sentiu ter sido de alguma forma descolado desta terra, quando buscou vida nova, e isto contribui para os significados que hoje a gleba possui para ele: um deles reside no de ser um trabalho que ele escolhe quando trabalhar, e não tem patrão. Os outros, ainda se investiga.

Casou-se com Dona Sandra, foi demitido juntamente com milhares de outros trabalhadores mediante a privatização, decidindo voltar. Voltar para trabalhar: panela de pedra era o que ele sabia fazer. Primeiro veio ele, depois a Sandra. Ela é a mais companheira dessas aqui, disse. Essa afirmação pareceu no início um amor profundo por sua esposa. Depois, compreendeu-se que ela também participa das atividades do galpão, ou seja, também faz panela, caso precise. Dona Sandra tentou desenvolver um trabalho com tapetes de sisal junto a outras mulheres do assentamento, mas, segundo ela, nem todas participavam. Neste momento de pesquisa, ela passou a trabalhar como cozinheira numa fazenda próxima. O sercompanheira está também na luta cotidiana: no lutar junto, no trabalhar.

Figura 15: À esquerda, Dona Sandra na III Feira da Agricultura Familiar do Estado de Minas Gerais Agriminas. Nesta ocasião, o INCRA-MG promoveu a exposição de produtos diversos oriundos de assentamentos de reforma agrária, e o Projeto de Assentamento (PA) Cafundão fora um deles. Na reportagem de onde se extraiu esta fotografia, houve menção ao fato de o assentamento ser considerado consolidado, o que na reportagem remete ao fato dele independer de políticas públicas ao seu mantimento ou sustentabilidade. Fonte: http://www.incra.gov.br/portal/index.php?option=com_content\& view=article\&id=10198:0\&catid=1:ultimas\&Itemid=278. Acesso em: 05 de abril de 2013.

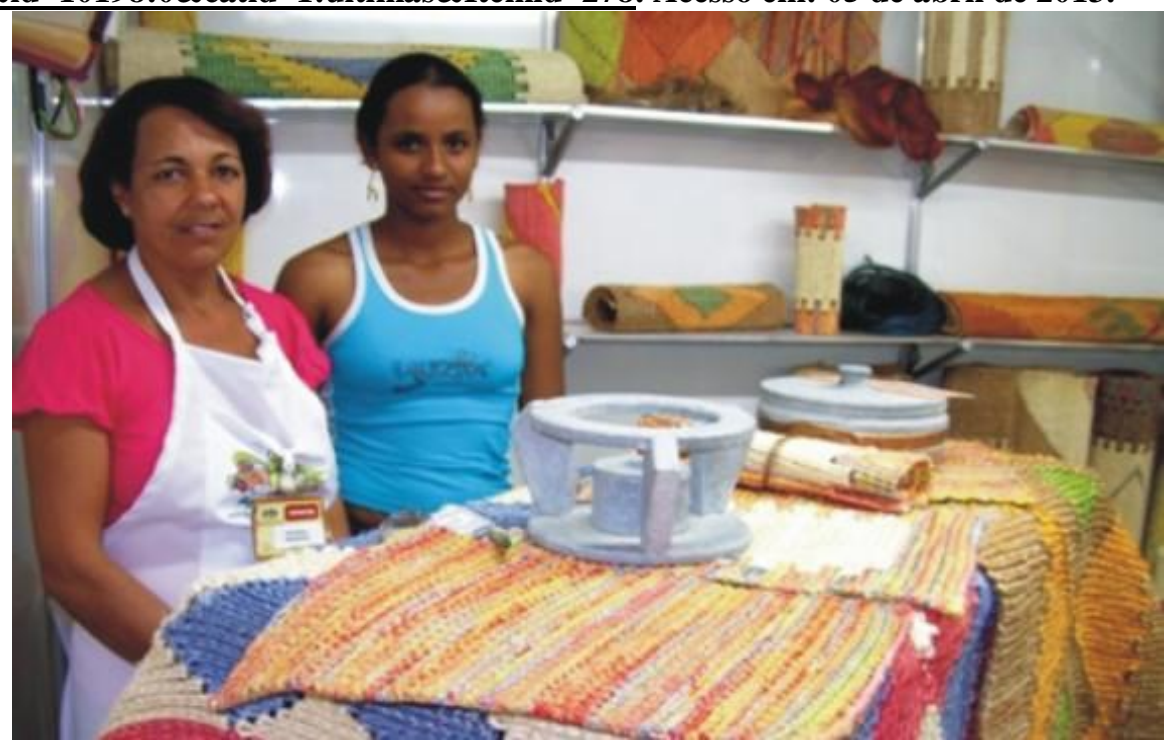


Já o senhor Adão apenas possui uma ideia do que é ter patrão, no sentido vivido pelo senhor Nilton de cumprir jornadas e obedecer a certas ordens. Sempre trabalhou no Cafundão, seja com panela, seja com atividades ligadas ao plantio. Apresentou o moinho mais antigo, já usado por eles, com roda d'água movida pela junção dos dois córregos, Bota Fogo e Forno de Telhas, que cortam as terras. Mas ela, a água, continua seguindo limpinha, alertou ele.

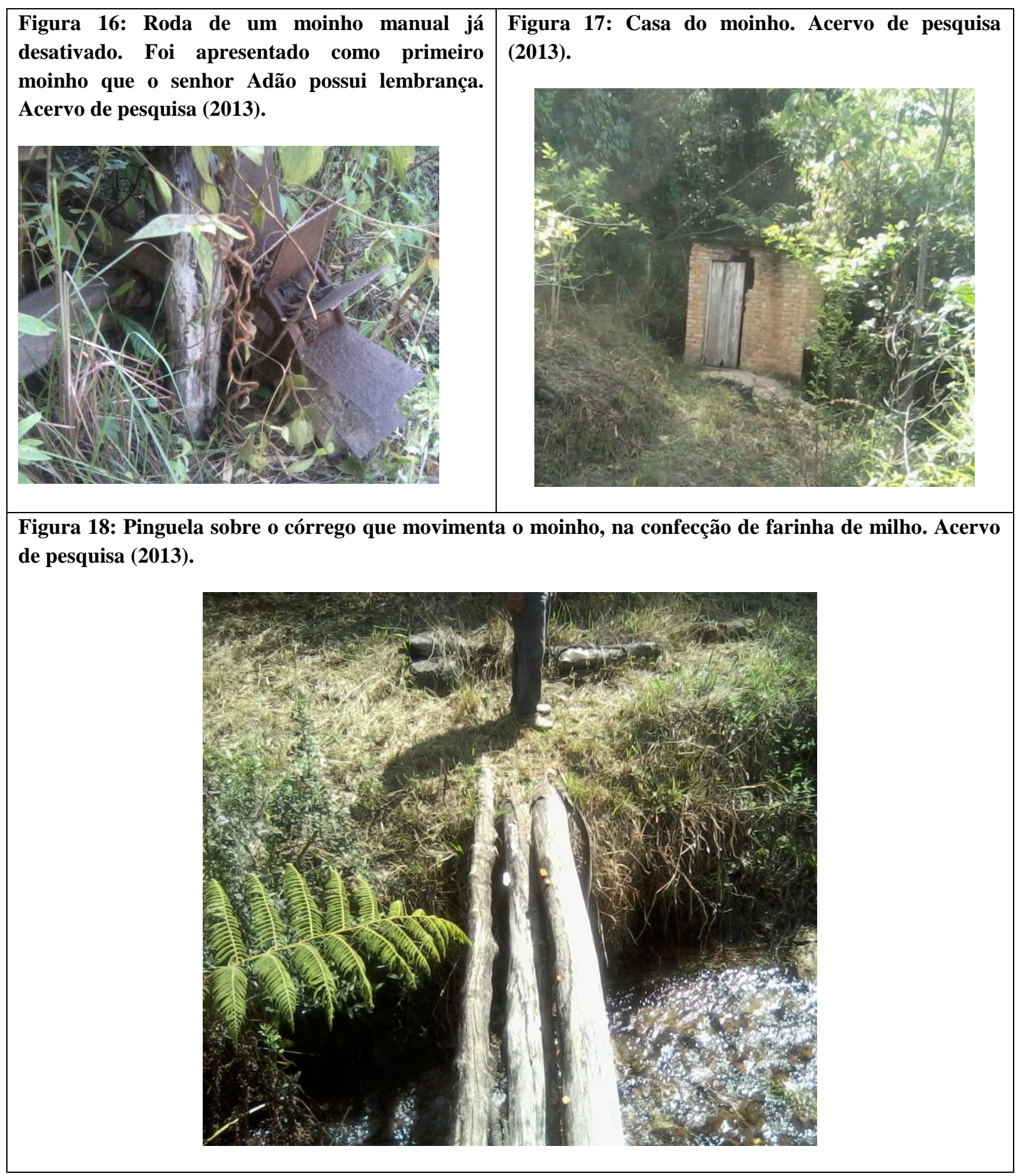


O senhor Adão é desconfiado, fala baixo, não é tanto de sorrir. Conseguiu-se isso algum tempo depois, entre um causo e outro. A atenção dele estava focada no Eu que poderia escrever a história. Era como se pedisse a todo tempo: escreve direito, com detalhes, tem que conhecer pra escrever.

Suas falas eram direcionadas, muito bem sistematizadas. A cronologia dos eventos relatados às vezes se confundia na memória, mas logo ele se encontrava. Percebeu-se que esta cronologia não é contada em anos: trata-se de um emaranhado de eventos que fomentam outros, e assim foi apresentado de forma firme e como um desabafo. Uma data se expressa a partir de eventos, relacionados a nascimentos, mortes, confrontos físicos, dias em que se foi ou se buscou órgãos e pessoas. A sucessão de eventos é apreendida através do emaranhado de acontecimentos: perguntando de várias formas, tenta-se descortinar memórias no atravessamento de audições e indagações.

Figura 19: Senhor Adão, na porta de entrada da casa do moinho. Acervo de pesquisa (2013).

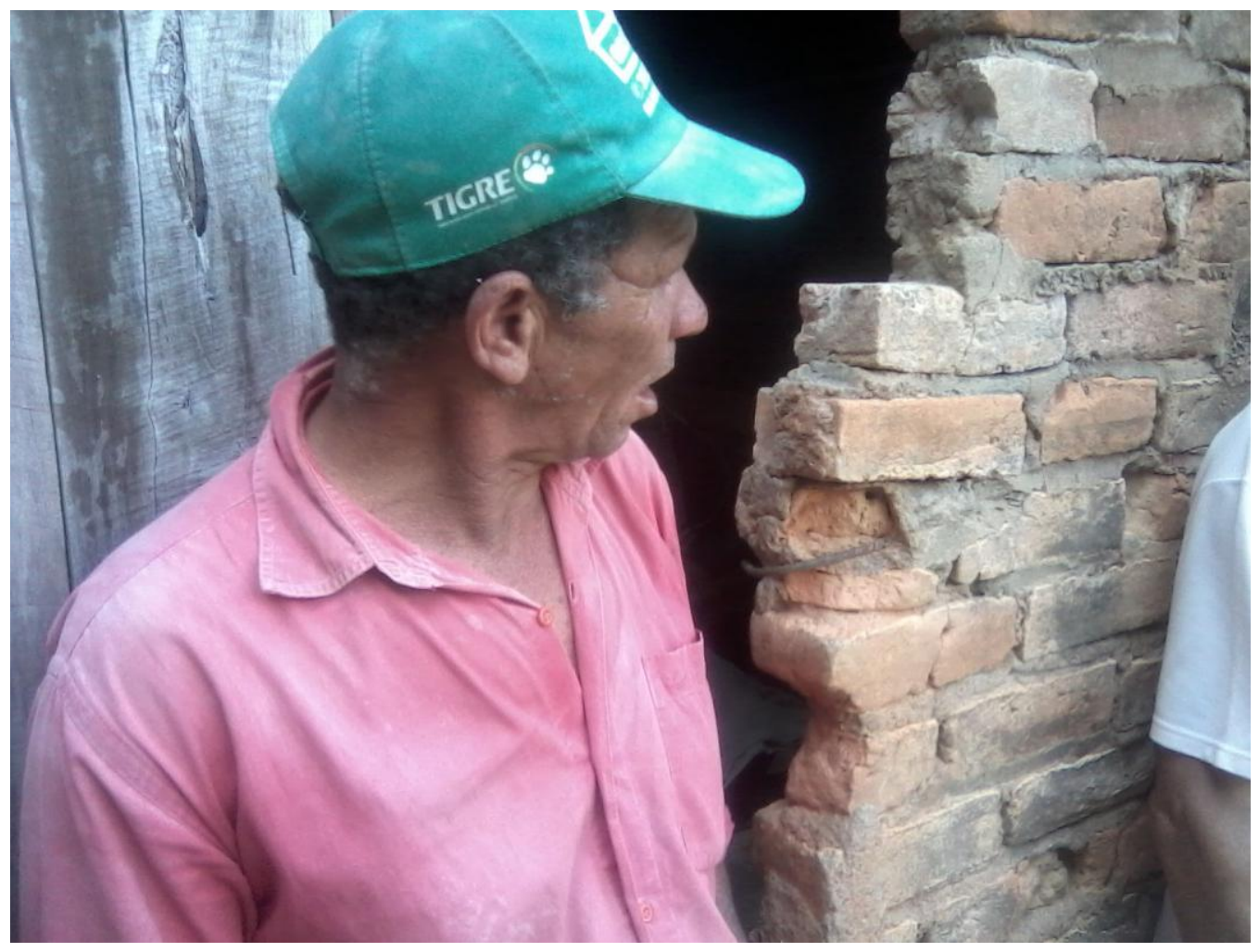

Senhor Adão fez um alerta de que alguns outros foram lá e não se interessaram pelos documentos que ele possuía: como contar uma história se não verifica o que aconteceu, de verdade? - ele indaga. Um desses outros, por ele apontado, trata-se justamente de uma visita 
de campo com estudantes da graduação em Geografia, ocasião de desdobramento desta pesquisa a partir do encontro com o Cafundão. Possuía o objetivo de desmitificar o olhar sobre o assentamento, ocorrido há cerca de três anos antes. Imaginava-se presenciar lonas, foices, bandeiras vermelhas, e encontrou-se gente comum.

O senhor Adão não sabe da inquietação da pesquisa surgida neste espaço-tempo, porque para ele pareceu pouco que um ônibus repleto de estudantes ficasse somente ouvindo o relato de sua história pelo Cafundão. Nesta ocasião, foram o senhor Nilton e a dona Sandra que respondiam atenciosos às perguntas de estudantes que não sabiam da existência deste assentamento bem próximo de onde moravam e estudavam. O senhor Adão afofava a terra, um pouco mais distante da aglomeração de estudantes que se formou, e explicava a alguns destes que ela poderia virar tijolo... Bastava ajudar!

Para o senhor Adão, necessário se fazia buscar a historiografia dos acontecimentos. Tinha que ver os documentos, diz ele, que agora entrega fotocopiados num envelope de papel pardo. Tem que se entender que ele é neto de Francisco da Cruz de Oliveira, diz firmemente, e a todo tempo. Por isto tudo, busca-se nesta textualização considerar os documentos e as vozes da luta.

O senhor Adão convidou para adentrar o galpão, e as conversas sobre a história de luta pela criação do assentamento começaram a acontecer... [...].

O desenrolar da conversa se deu no interior do galpão. Aliás, este galpão de torneamento de panela de pedra traduz toda a peculiaridade deste assentamento, que fomentou a curiosidade acerca de sua luta. Isto por que, a partir de um cenário brasileiro mais amplo, pautado grandemente no que se chama de historicidade da questão da terra, chega-se numa política de reforma agrária como forma de mitigar a insatisfação inerente à desigualdade agrária e do acesso a terra. Este próximo capítulo tratará do contexto jurídico de criação de tal política, e suas diretrizes priorizando o que se chama de a função social da terra, que é a sua versão de servir ao cultivo. No próximo capítulo, irá se dedicar aos documentos entregues pelo senhor Adão, na construção de uma versão da sociogênese da luta pelo assentamento. 
Figura 20: Visão da parte da frente, e externa, do galpão com os blocos ao torneamento. À direita, a estrada de acesso ao assentamento, com lotes com plantação de eucalipto. E à esquerda, íngreme em direção ao córrego, a área do assentamento. Acervo de pesquisa (2013).

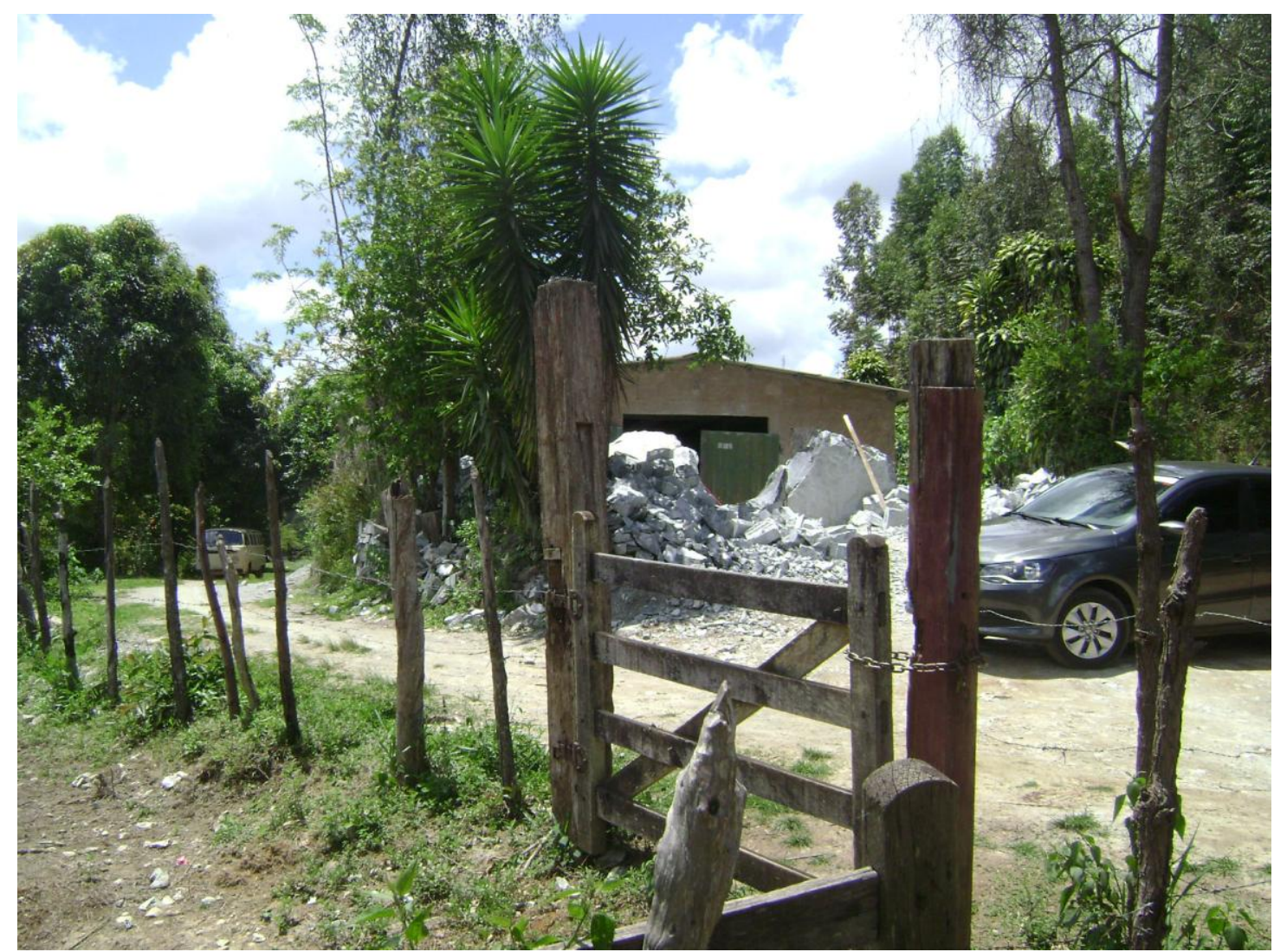

Os assentamentos de reforma agrária possuem também esta justificativa de existência de aumento da produção de alimentos, mediante uma sociedade que questiona o porquê da concessão de terras, e que por vezes revelam profundo desconhecimento acerca de que, quando concedidas, isso se dá através de lutas legítimas e do posterior pagamento por elas. No caso do Cafundão, a função social da terra seria interessante de ser analisada, tendo em vista que a atividade principal é o torneamento de esteatito à confecção de panelas. Ao passo que o conjunto de Leis Agrárias incita grandemente o aumento da produtividade da terra em seu sentido agrícola, a complexidade da vida social que se dá na e pela terra sugere maior cautela na investigação.

Neste sentido, cita-se, como exemplo, as ciências sociais que investigam as atividades não-agrícolas enquanto fenômeno social e econômico presente na estruturação agrária. As atividades não-agrícolas, associadas àquelas agrícolas que adentram mercados ou se restringem a uma rede menor de consumo e comercialização, se faz presente no debate enquanto forma de se garantir na própria terra. Ecoturismo, turismo rural e artesanato são 
exemplos de atividades não-agrícolas que inserem na complexidade do mundo rural também como forma de permanecer nele. As atividades agrícolas e não-agrícolas se associam na reconstrução de outros novos significados dados a uma terra antes concebida estritamente em seu aspecto produtivo. Sobre isso, Sérgio Schneider (2003) concebe que certas atividades nãoagrícolas podem ser reconhecidas enquanto "pluriatividade" num sentido de designar

uma prática social da busca de formas alternativas para garantir a reprodução das famílias de agricultores [familiares]. [...] Isto não significa que outras formas sociais de uso da terra e do trabalho, que não as familiares, não possam ter, na prática da pluriatividade, um dos mecanismos de reprodução, ou mesmo de ampliação de fontes alternativas de renda. (SCHNEIDER, 2003, p. 91).

Deste modo, há uma tentativa de ampliar o escopo de análise que caracterizaria a complexidade do rural brasileiro pautado na distinção entre modo de vida, estruturação agrária e atividade agrícola. Em outras palavras, os assentamentos de reforma agrária iriam além da promoção do acesso a terra ao seu posterior cultivo agrícola: ele assumiria suas feições rurais de apreenderem memórias e identidades ligadas de alguma maneira a terra, seja enquanto morada, trabalho, conquista, moeda de troca, lugar ou quaisquer outras significações possíveis e necessárias de investigação. De tal forma que os estudos passam a considerarem que a conquista da terra seria uma expressão do significado exaltado que esta terra possuiria antes da conquista, e seria também marco de recriação de demais significâncias oriundas da vida na terra e da luta cotidiana para nela permanecer.

Faz-se necessário este entendimento para não descaracterizar a luta pela terra do Cafundão a partir da atividade que hoje é predominante e que esta ligada a terra de forma diferenciada do seu cultivo: que é a fabricação de panelas de pedra. Ao mesmo tempo, em que esta atividade também convive com outras formas de vender o trabalho, como o desempenho de atividades em empresas de mineração local ou em serviços ligados a atividades desempenhadas em casas e fazendas, designadas comumente como domésticas. Não será alvo aqui de análise, mas ressalta-se que seria pertinente um estudo acerca das variantes trabalho e relações de gênero que hoje caracterizam o rural brasileiro que é plural, que é movente, mas que contém permanências sociais, tal como o trabalho doméstico - lavar, passar, cozinhar, cuidar de crianças - ser eminentemente executado pela mulher. Estudo este que iria se tornar 
cada vez mais complexo ao considerar outras variáveis como renda familiar, salário, idade, proximidade para com densos centros urbanos, etc.

Porquanto, há de se considerar os assentados enquanto aqueles que se dedicam à atividade não-agrícola no sentido dado por Schneider (2003), se utilizam da agricultura e da criação de animais para suprir carências alimentares de cunho familiar, compram na sede do município os alimentos que compõe a alimentação básica e cotidiana - que seria o arroz, o feijão, o açúcar, o sal, o óleo, etc; e por isto a inserção produtiva agrícola local não é tão expressiva. Por este motivo, o torneamento de panelas de pedra emerge enquanto eixo central e prioritário de pesquisa, fomentador de renda, de trabalho e que possui também uma outra versão que será mais bem discutida nos Capítulos 03 e 04, que reside na própria marcação espaço-tempo dos assentados.

Neste sentido, identificou-se no desenrolar da pesquisa a importância das conversações se darem no interior do galpão de torneamento de panelas, quando não se estava em Travessia. Enquanto lugar que motiva e justifica a própria memória de luta por esta terra onde se torneia, funcionou também como fator de interação entre o Eu e o Outro. No campo da pesquisa, questionava-se algum elemento pertencente ao trabalho que ali se desenvolvia, e este interesse gerava uma maior aproximação entre os construtores dessa pesquisa, no intuito de se permitir o adentrar em territórios de memória, sem que se faça de forma a violá-la.

Aliás, por este motivo é que não se insistiu em conhecer o interior das casas e de realizar a observância das dinâmicas familiares. Percebeu-se que a apresentação do objetivo desta pesquisa correlacionada ao histórico de luta elevou a importância da Cooperativa e do conhecer as terras do Cafundão. As terras, conhecidas por meio da Travessia, eram as casas dos assentados, enquanto que os seus lares não necessitavam ser descortinados. Uma tentativa de adentrar estes territórios eram, de início, entendidos enquanto violações. Somente no final do desenvolvimento da pesquisa que copos d'água passaram a ser oferecidos enquanto se espera no sofá da sala. Limonadas com limões recém colhidos eram ofertados de forma desconfiada por aqueles em seus lares, e sempre vigiado pelo senhor Adão que guiou a realização da própria pesquisa.

Esta postura se relaciona à consideração das narrativas de vidas espaciais (LINDÓN, 2008) enquanto instrumento teórico-metodológico de pesquisa. Isto porque, para Alícia Lindón (2008), a narrativa dos sujeitos que se estuda seria uma forma de apreender o espaço percebido, representado e também construído por eles. 
Cuando las prácticas espaciales son narradas o relatadas por el sujetohabitante que las ha realizado, el relato incluye una riqueza adicional a la caracterización de los acontecimientos, que siempre estarán más o menos distorsionados en relación con los hechos que le dieron origen. Esa riqueza adicional consiste en que los acontecimientos (la componente fáctica) se va articulando en la narrativa con retazos de uma trama de sentido que para el sujeto tiene valor, y constituye parte de los cristales a través de los cuales ve y evalúa el mundo, y actúa en él. Entonces, si el tercer camino metodológico del discurso sobre lãs prácticas y su espacialidad es una apuesta legítima y de gran potencial para la investigación geográfica cualitativa, dentro de todas las formas de discursividad, las narrativas de vida constituyen uno de los núcleos de mayor riqueza, y dentro de ellas las que denominamos narrativas de vida espaciales (LINDÓN, 2008, p.10).

Como artifício qualitativo de pesquisa, a autora considera que elencar um eixo de análise, que em torno do qual se dariam as conversas, é também buscar uma via alternativa, não-hegemônica e não-engessada, e particular de se construir uma pesquisa junto àquele que se investiga. É abrir-se à consideração das múltiplas interpretações que poderiam sobrevir da observância em torno daquilo sobressaltado, valorizado, negado e silenciado pelos sujeitos. Considerar as narrativas de vidas que são entrecruzadas ao espaço de sua construção é espacializar o que se apreende, é considerar suas versões híbridas, particulares, seus movimentos.

De maneira geral, segundo Lindón (2008), as narrativas de vidas espaciais seriam construídas a partir de formas de captação alternativas e abrangentes. A entrevista, sendo uma dessas formas, poderia ser usada desde que com roteiros não enrijecidos e não manipuladores da ordem do discurso que se pretende ouvir. Teriam que se dar como conversas pautadas em diálogo, no qual se admite interferência do Eu sobre o Outro, mas preocupando-se, principalmente, em ouvi-lo. Alícia Lindón (2008) destaca que as narrativas de vidas espaciais tem que ser concebidas para além de entrevistas, a despeito de requererem as situações de entrevistas. São abordagens discursivas complexas que abarcam dimensões simbólicas e culturais, que não se prendem àquilo que foi dito: os silêncios, o esquecimento e o não-dito também dialogam como representações. Admite-se representações que não se verbalizam. Admite-se representações que escapam ao entendimento sendo entendidas por quem as inventou. Construir narrativas é abrir-se à complexidade interpretativa (RÚBIO, 2012, p. 36).

Dessa forma, assume-se as narrativas e seu tangenciamento ao espaço, que se resume ao instrumento teórico-metodológico de considerar narrativas de vidas espaciais, por estas 
expressarem movências, singularidades e formatações particulares de um indivíduo. Priorizase a audição da história de luta pela terra, estrutura-se o diálogo em torno deste eixo, ao mesmo tempo em que se abre o leque para a apreensão de suas narrativas acerca de si próprios, do mundo que faz parte e daquele mundo que eles criam. Neste sentido, silêncios e esquecimentos (POLLAK, 1989) são considerados feições daquilo que querem lembrar, representar, expressar, negar.

Esta preocupação de se chegar ao Cafundão se utilizando de escopos teóricos se complexifica, portanto, através do entendimento de que não é somente a luta pela terra que adquire um sentido diferencial e singular. Ou seja, a luta pela terra não possuiria somente motivações amplamente ligadas ao histórico de desigualdade fundiária, o que poderia tornar a história de luta pelo Cafundão um exemplo ou um número do indicador de pressão social. Há também a análise do próprio assentamento em si, que se pauta na lapidação da rocha que aflora na região do assentamento, enquanto expressão particular de se estar ligado a terra, tendo em vista outros baseados no cultivo da terra, na plantação e lavoura.

Destaca-se que esse grupo estudado é constituído por doze famílias, o que contabilizou aproximadamente sessenta pessoas, a despeito de nem todas quererem ao menos se apresentar, e outras tantas não estavam em vários momentos da pesquisa de campo. Até porque, se verificou um início de um processo de repasse de lotes a outrem interessado em se tornar assentado. Este processo tem sido acompanhado pelo INCRA na medida em que se verifica no Sistema de acompanhamento denominado SIPRA a mudança gradual dos beneficiários, sendo que a família do senhor Adão é aquela que ainda se mantém nas terras conforme a origem da criação do assentamento.

Foi pretendido entrevistar os homens e as mulheres que fizeram parte da fase da luta considerada o ápice das tensões, em que conflitos armados se fizeram presentes; como também, aqueles que possuem a memória da luta transmitida por seus pais, que nasceram no assentamento ou que eram jovens quando vivenciado o mencionado ápice; e uma família que se sabe possuir memória construída por tabela, na medida em que foi contemplada pela política a partir de uma desistência de uma outra família em vésperas de criação do assentamento. Pretendeu-se, portanto, contemplar todas as famílias, priorizando questões de gênero, genealógicas e de interação familiar.

No entanto, ressalta-se que poderia haver o problema de se realizar um tratamento homogêneo ao considerar o próprio ser-assentado enquanto identidade uniforme e 
designadora de posturas, atitudes e de memórias de todos aqueles que moram no assentamento. Ressalta-se, enquanto algo hipotético, que o ser-assentado seria sim um $a$ posteriori daqueles que lutaram e/ou moram no assentamento, mas que não necessariamente se dá pela agregação passiva desta suposta identidade coletiva. Não é porque certos indivíduos são considerados pelo Estado assentados de reforma agrária que eles desenvolvem uma identificação generalizada com tal designo, que aqui se entende enquanto espécie de identidade a ser investigada. Haver-se-ia, pois, negações do ser-assentado, que também seriam formas de expressar a relação do indivíduo com este ser-assentado coletivo que se investiga, como fora percebido em negações de entrevista acerca do histórico de luta. Como também, haver-se-ia diferentes relações de outros, que não são assentados, com estes que são contemplados por política pública de criação do assentamento, expresso na relação Cafundão de Baixo e Cafundão de Cima.

A postura teórico-metodológica aqui assumida, pautada em Lindón (2008), considera, portanto, o assentamento enquanto expressão plural de uma totalidade que lhe dá substância e sentido. Mas o assentamento não seria a escala mínima de investigação, na medida em que se forja também na escala do indivíduo suas memórias, e nem sempre o coletivo expressa as vozes daqueles representados por ele.

Explica-se, portanto, enquanto desdobramento teórico-metodológico, que a história de luta pelo assentamento é contada como numa estória: onde a cronologia historiográfica se faz muito mais através do espaço-tempo escolhido por quem conta, sendo coinfluenciado através de questionamentos que remetem ao eixo central de pesquisa: que é a versão de luta, no plural. Deste modo, se dialogará neste capítulo sobre a jurisprudência agrária para se chegar à petição desta política pública feita pelos assentados, a ser melhor enfocado.

Não se pretende esgotar essa discussão sobre as criações e formatações das leis agrárias ao longo da história de formação do território brasileiro. Ressalta-se, porém, que a análise de alguns aspectos mostra-se importante ao entendimento de como a questão da terra vem sendo edificada, a partir, por exemplo, da apreensão do tratamento dado pelo Estado, ou melhor, por aqueles que estão e que estiveram na sua linha de frente, inclusive quando ainda não se tratava de um Estado Democrático. É como se o olhar sobre a legislação e a jurisprudência permitisse entender, ou ao menos sugerir, o sentido e o embasamento teórico, político e ideológico que sustenta o corpo jurídico de leis, no que concerne também ao seu aspecto agrário. Inicia-se, portanto, com as primeiras Leis que tentam reger o acesso às terras 
brasileiras, que foram incorporadas da e pela Coroa Portuguesa para que dispusesse sobre aquelas do Brasil.

\subsection{Alguns aspectos da jurisprudência agrária brasileira}

A Lei de 29 de junho de 1375, assinada em Lisboa pelo rei Fernando I, institui a obrigatoriedade da "prática da lavoura e o semeio da terra pelos proprietários, arrendatários, foreiros e outros" (BRASIL/MDA, 2007).

Todos os que tiverem herdades próprias, emprazadas, aforadas, ou por qualquer outro título, que sobre as mesmas lhes dê direito, sejam constrangidos a lavrá-las e semeá-las. Se por algum motivo legítimo as não puderem lavrar todas, lavrem a parte que lhes parecer podem comodamente lavrar, a bem vistas e determinação dos que sobre este objeto tiverem intendência; e as mais façam-nas aproveitar por outrem pelo modo que lhes parecer mais vantajoso de modo que todas venham a ser aproveitadas. ${ }^{25}$

Nelson Nozoe (2006), que realiza uma análise da legislação portuguesa que foi aplicada no processo de colonialidade ${ }^{26}$ do Brasil, denomina-a de Lei das Sesmarias. Antes da incorporação ao Brasil, esta lei agrária significou a Portugal uma maneira de se fomentar a "produção agrícola e o cultivo das terras ermas - reconquistadas aos mouros ou deixadas ao abandono por conta do declínio da população rural dizimada pela peste negra ou rarefeita pelo êxodo em direção aos centros urbanos -, a medida foi, posteriormente, denominada das sesmarias" (NOZOE, 2006, p. 588).

Este autor ressalta que esta Lei foi o principal meio legal de obtenção de terras durante o período colonial brasileiro, a despeito de ter se dado de forma fragmentada, sendo ratificada e alterada por meio de muitas resoluções, durante todo este período. Comenta que há dúvidas

25 Texto da Lei encontrado no endereço: http://arisp.files.wordpress.com/2009/07/lei_de_26-061375_sesmaria.pdf. Acesso em: 04 de fevereiro de 2014.

26 “Colonialidade do poder é um conceito que dá conta de um dos elementos fundantes do atual padrão de poder, a classificação social básica e universal da população do planeta em torno da idéia de 'raça'. Essa idéia e a classificação social nela baseada (ou 'racista') foram originadas há 500 anos junto com América, Europa e o capitalismo. São a mais profunda e perdurável expressão da dominação colonial e foram impostas sobre toda a população do planeta no curso da expansão do colonialismo europeu. Desde então, no atual padrão mundial de poder, impregnam todas e cada uma das áreas de existência social e constituem a mais profunda e eficaz forma de dominação social, material e intersubjetiva, e são, por isso mesmo, a base intersubjetiva mais universal de dominação política dentro do atual padrão de poder.” (QUIJANO, 2002, p. 04). 
em relação à data legítima de sua assinatura, mas isso corresponderia a uma diferença de meses, permanecendo o ano de 1375 como representativo da escrita de uma jurisdição incorporada ao Brasil-Colônia.

E isso perdura até o início do século XIX. "Pequenos produtores apropriaram-se de terras devolutas mediante simples ocupação, conhecida como posse. Às vésperas da independência, a prática da doação de terras por sesmaria foi suspensa sem que outro instrumento legal fosse promulgado em substituição" (NOZOE, 2006, p. 587). Havia o interesse manifesto da Coroa em ocupar, através da concessão de terras e do incentivo à agricultura concomitantemente à pastagem, os limites demarcados como Brasil, a fim de garantir uma maior regência. "A transposição deste instituto jurídico para terras brasileiras deu-se em face do desejo da Coroa portuguesa de promover o povoamento e o aproveitamento por particulares, de um lado, e, de outro, da ausência de um meio legal alternativo para viabilizar aqueles intentos" (NOZOE, 2006, p. 587).

Este autor salienta que esta jurisdição ensejou aqueles lotes dedicados ao povoamento com aproveitamento através do cultivo e da pastagem, até a Independência do Brasil, no início do século XIX. E que há regulamentações específicas para os casos de mineração, aos quais ele denomina de "terras minerais" concedidas por Oficiais, Superintendentes e Guardasmores das minas, já no século XVII. Como também, há para aqueles casos ligados à formação de vilas e de cidades, com lotes concedidos por oficiais da Câmara a pedido de moradores.

As capitanias hereditárias, como ficaram conhecidas as faixas de terras concedidas aos membros da corte que eram de confiança do Rei - denominados de Capitães-Donatários passaram a representar o interesse pela fixação neste território e o desenvolvimento local, através das fundações de vilas e cidades. Estes Donatários “contavam como propriedade pessoal apenas uma parcela; comprometiam-se a distribuir o restante sob a forma de sesmaria, a quaisquer pessoas, de qualquer condição, comtanto que fossem christãos". (NOZOE, 2006, p. 590, grifos do autor).

A imagem a seguir acerca das fragmentações das capitanias hereditárias, que se tornou representativa das demarcações que marcaram o território brasileiro no século XVI, mas que exercem influência espacial sobre períodos subsequentes, tem tentado ser substituído por um redesenho que expresse, de fato, as subdivisões referentes às ocupações de famílias nobres portuguesas. 
Figura 21: Capitanias Hereditárias. (Luís Teixeira. Roteiro de todos os sinais. 1586. Lisboa, Biblioteca da Ajuda)._Retirada do sítio: http://pt.wikipedia.org/wiki/Capitanias_do Brasil. Acesso em: 13 de fevereiro de 2014.

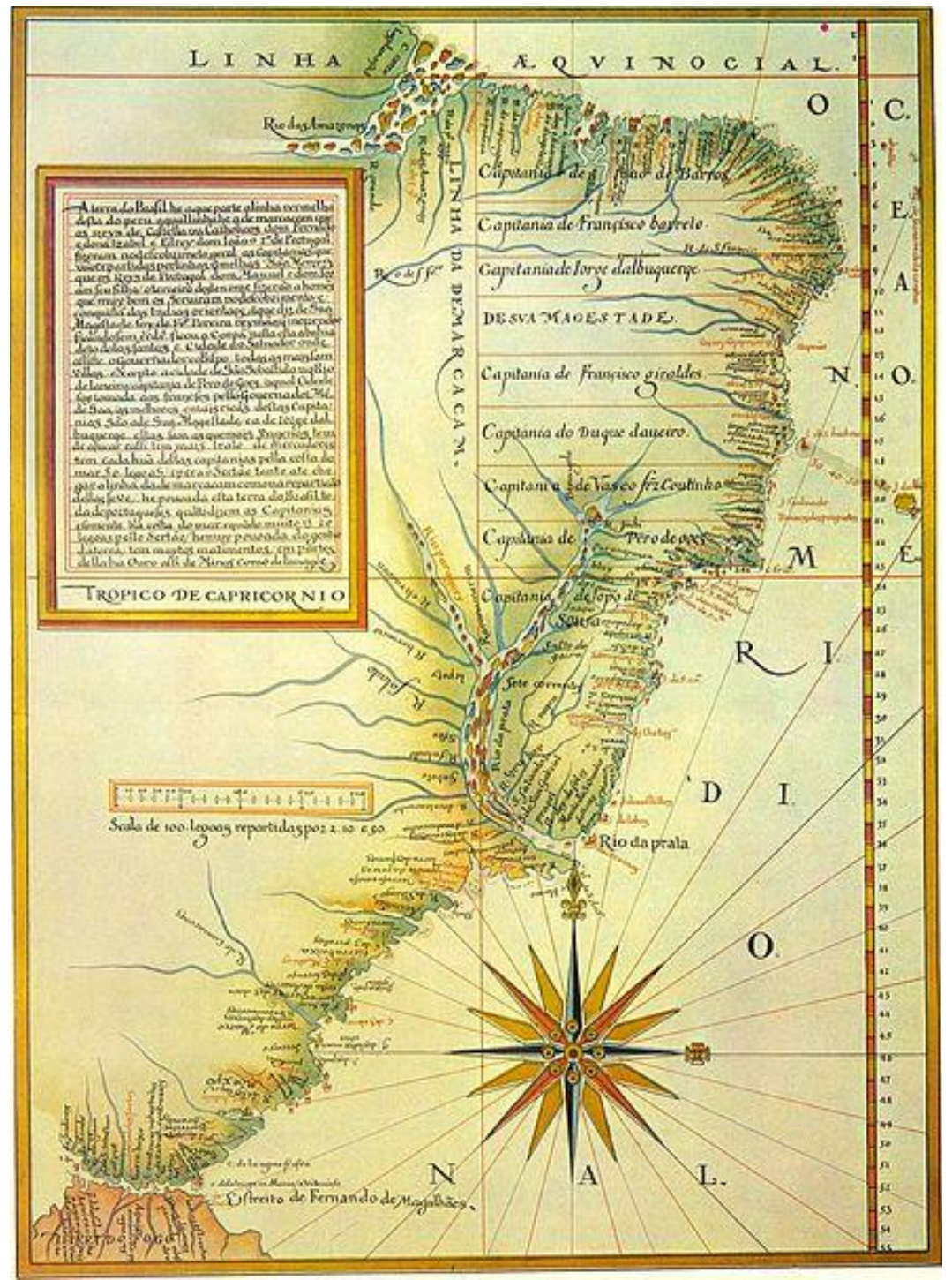

A partir de uma revisão de fontes primárias e da historiografia, Jorge Cintra ${ }^{27}$, numa pesquisa iniciada em 2013 sobre a Cartografia das Capitanias Hereditárias, tem constatado por que a pesquisa ainda está em desenvolvimento na Universidade de São Paulo - que essa distribuição completamente horizontal ou latitudinal das Capitanias pode estar equivocada. Este professor apresentou possíveis possibilidades de haver territórios com distribuição

\footnotetext{
${ }^{27}$ Em reportagem intitulada "Novo Mapa das Capitanias Hereditárias poderia constar em livros didáticos a partir de 2017", O Globo de julho de 2014. O endereço eletrônico da reportagem está disponível em: http://oglobo.globo.com/sociedade/educacao/novo-mapa-de-capitanias-hereditarias-poderia-constar-em-livrosdidaticos-partir-de-2017-13192043. Acesso em 06 de outubro de 2014.
} 
longitudinal, principalmente alguns situados ao nordeste e ao sul do país, como demonstra a figura a seguir.

Figura 22: Nova disposição das Capitanias Hereditárias referente às ocupações que se deram entre os anos 1534-1536. Imagem retirada de reportagem que divulga a pesquisa que tem sido elaborada pelo professor Dr. Jorge Pimentel Cintra, da Universidade de São Paulo.

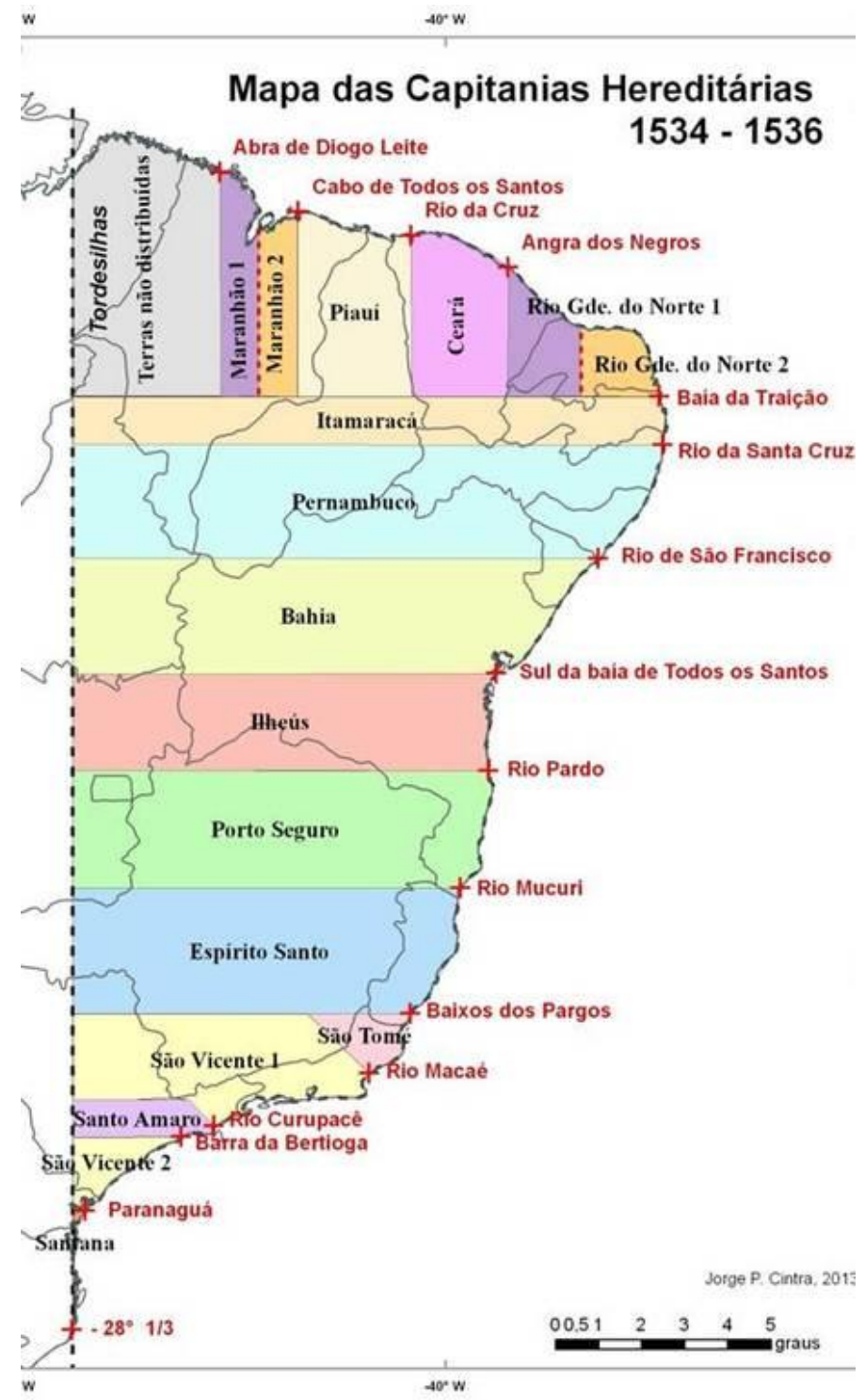

Contudo, como bem ressalta o geógrafo Jurandir Ross ${ }^{28}$, “estabelecer os limites precisos das capitanias é relevante, mas não muda a compreensão do essencial", que reside no

\footnotetext{
${ }^{28}$ Conforme reportagem de O Globo (2014) intitulada "Novo mapa de capitanias hereditárias poderia constar em livros didáticos a partir de 2017", de Leonardo Vieira e Mateus Campos, disponível em: http://oglobo.globo.com/sociedade/educacao/novo-mapa-de-capitanias-hereditarias-poderia-constar-em-livrosdidaticos-partir-de-2017-13192043. Acesso em: 06 de outubro de 2014.
} 
aspecto histórico que essa divisão representa para a construção do espaço brasileiro, tanto no formato de administração de terras adotado pela Coroa, quanto na raiz da desigualdade do acesso a terra.

Porquanto, neste momento, a estruturação agrária brasileira pautou-se, de forma generalizada, no intermédio da posse como forma de acesso a terra, expresso também a partir das capitanias como forma de otimizar a ocupação. Bastava, como afirma Nozoe (2006), ser cristão, reconhecendo-se a Ordem de Cristo, e possuir o interesse no cultivo, sob pena de transferência ao bem comum da terra para posterior redistribuição. Aliás, coabitavam duas principais formas de poder em terras brasileiras, que desconsideravam - e ainda desconsideram - quaisquer direitos de propriedades daqueles que residiam antes da chegada dos portugueses, acoplados sumariamente na conceituação índio. As duas formas de poder dizem respeito àquelas advindas das ordenações do Reino e àquelas das bulas-papais, instituídas nos Ordenamentos e na Ordem de Cristo, respectivamente. Nelson Nozoe (2006, p. 589) chama de "conjuntos distintos, e por vezes conflitantes, de normas".

A Lei das Sesmarias tornou-se providencial à convivência destes conjuntos de normas, até a promulgação do Império, no século XIX. Isto por que, a Ordem de Cristo alegava que a cobrança do dízimo seria em face de seus gastos com a propagação da fé, com as conquistas ultramarinas e, além disso, estas terras estavam sob sua jurisdição espiritual. Ao passo que, os Ordenamentos não mencionam a cobrança de dízimo, proibiam que Ordens religiosas Ordens, Igrejas e Mosteiros - se apropriassem daquelas terras não lavradas e nem sob posse, também chamadas de maninhos.

Como essas entidades, entre elas a Ordem de Cristo, achavam-se impedidas de fazer uso de contratos de aforamento ou enfiteuse com os povoadores, inevitável se tornava a transplantação do instituto das sesmarias, para a terra achada por Cabral, suposto que meio legal diverso não havia para povoamento da imensa gleba, ainda inviolada. Em decorrência, ficava subentendido que os maninhos descobertos no Brasil constituíam propriedade da Coroa portuguesa, ainda que sobre seus beneficiários recaísse a obrigatoriedade do pagamento de dízimos à Ordem de Cristo (NOZOE, 2006, p. 589-590)

Estes mencionados contratos de enfiteuse dizem respeito a um processo jurídico que se esbarra na história de luta pelo Cafundão. Juridicamente, as terras do Município de MarianaMG, e outras tantas, que não haviam sido apropriadas por concessão das Ordenações, e que 
não tivessem sido lavradas, poderiam ser incorporadas pelo contrato enfiteuse. $\mathrm{O}$ contrato de enfiteuse seria, segundo José Carlos Salles (2010), uma forma de usucapião de direitos reais sobre coisas alheias. Ou seja, a propriedade ainda seria do Reino, porém, o enfiteuta teria uma concessão de usufruir tais terras, contanto que pagasse uma espécie de imposto.

Nisso reside o surgimento das noções de privado e público, em terras brasileiras. Isto porque, para Nelson Nozoe (2006), a consideração de que todas as terras estavam sob soberania do Reino desde o descobrimento, e que havia casos de apossamentos, como por exemplo, àqueles feitos por donatários e concessões de uso àqueles que lavrassem a terra, edificam a noção de público no Brasil. Nesta noção de público, cabia ao Reino toda a soberania na decisão, inclusive em casos de reapossamento de terras já concedidas. Ao passo que, esta última questão acerca do reapossamento permitido pelo Reino é o que orienta a análise de Carlos Castilho Cabral (1943) para a edificação da noção de privado no Brasil. Isto por que, ao considerar um território desprovido do sistema de posse, neste cenário os habitantes chamados de indígenas foram completamente desconsiderados, a reconversão de terras caracterizaria uma espécie de privatização, de um sistema privado de posse sobre terras alheias. A despeito das nomenclaturas público e privado serem essencialmente diferentes, neste caso a análise caminha para um viés comum: o de considerar o Reino soberano, por mais que ele passasse a representar o princípio do Estado brasileiro, através da edificação de ser bem-comum ou público, ou o princípio da propriedade já advindo da invasão de terras posteriormente chamadas de brasileiras, e da aplicação de jurisdições para que regesse aqui.

Tal instituto jurídico da enfiteuse fora proibido às Ordens, como a Ordem de Cristo, conforme mencionado por Nelson Nozoe (2006, p. 589-590). Há, portanto, um dilema para ser explicado: se a enfiteuse era proibida à Ordem de Cristo, como explicar que o INCRA teve que comprar da Igreja católica, na figura da Paróquia de Nossa Senhora de Cachoeira do Brumado, os oito hectares de terras respectivas ao Cafundão, para fins de reforma agrária? Talvez essa questão se descortine mais adiante a partir da cronologia dos acontecimentos e das fomentações de leis, no que concerne ao assentamento.

A suspensão desse regime de sesmarias se deu através da Resolução no 76 de 17 de julho de 1822, expedida pelo Reino, e perdurou até a convocação da Assembleia Constituinte, que construiria em 1824, como Dispositivo Constitucional, a Constituição Política do Império 
do Brasil (BRASIL/MDA, 2007). Nesta Constituição, de 25 de março de $1824^{29}$, firmando o Brasil enquanto nação independente e a "Religião Catholica Apostolica Romana" como religião única, há uma preocupação nítida em organizar essa nova estrutura política de governo, que passa a ser o Império do Brasil, regido pelo imperador Dom Pedro I.

Destaca-se que não se tem a pretensão de aprofundar nessa estrutura política do Império, mas percebe-se a composição dos Poderes em Legislativo, Moderador, Executivo e Judiciário, e as representações da Nação, que se daria na figura do Imperador e da Assembleia Geral, ficando a segunda amplamente subordinada à soberania da primeira. Tem-se também o já presumido regime de Regência e escolha do tutor, que se daria com o seu filho, Pedro II, a partir de 1831, após abdicação do então Imperador. Não se faz referência ainda à questão fundiária brasileira, firmando somente o sentido de propriedade que reside na casa do brasileiro enquanto "asylo inviolável” (BRASIL, 1824).

Segundo Nelson Nozoe (2006), há a suspensão do regime de sesmarias através dessa Constituição, que emerge o Brasil enquanto nação independente, mas o regime de posse enquanto principal forma de acesso a terra ainda imperou até a Lei ${ }^{\circ} 601$ de 18 de setembro de $1850^{30}$, ou como ficou conhecida a Lei de Terras. Esta Lei foi uma tentativa de institucionalizar as formas de acesso, e criar uma certa norma jurídica sobre as terras devolutas do Império.

Dispõe sobre as terras devolutas no Império, e acerca das que são possuídas por titulo de sesmaria sem preenchimento das condições legais. Bem como por simples titulo de posse mansa e pacifica; e determina que, medidas e demarcadas as primeiras, sejam elas cedidas a titulo oneroso, assim para empresas particulares, como para o estabelecimento de colonias de nacionaes e de extrangeiros, autorizado o Governo a promover a colonisação extrangeira na forma que se declara (BRASIL, 1850).

Terras devolutas é a designação para aquelas terras que não cumprem com determinadas especificações e se tornam pertencentes à União. Tais especificações dizem respeito ao cumprimento, ou não, dos seguintes artigos da Lei de Terras, a saber:

Art. $3^{\circ}$ São terras devolutas:

29 Texto da Constituição de 25 de março de 1824, disponível na íntegra, em: http://www.planalto.gov.br/Ccivil_03/Constituicao/Constituicao24.htm. Acesso em: 06 de fevereiro de 2014.

Texto da Lei $\mathrm{n}^{\mathbf{o}} 601$ de 18 de setembro de 1850, disponível na íntegra em: Acesso em: http://www.planalto.gov.br/ccivil_03/Leis/L0601-1850.htm. 06 de fevereiro de 2014. 
$\S 1^{\circ}$ As que não se acharem applicadas a algum uso publico nacional, provincial, ou municipal.

$\S 2^{\circ}$ As que não se acharem no dominio particular por qualquer titulo legitimo, nem forem havidas por sesmarias e outras concessões do Governo Geral ou Provincial, não incursas em commisso por falta do cumprimento das condições de medição, confirmação e cultura.

$\S 3^{\circ}$ As que não se acharem dadas por sesmarias, ou outras concessões do Governo, que, apezar de incursas em commisso, forem revalidadas por esta Lei.

$\S 4^{\circ}$ As que não se acharem occupadas por posses, que, apezar de não se fundarem em titulo legal, forem legitimadas por esta Lei (BRASIL, 1850).

A partir desta Lei, a compra passa a ser o principal modelo de aquisição de terras devolutas, substituindo o sistema da posse, conforme o seu artigo primeiro no qual se estabelece que "Ficam prohibidas as acquisições de terras devolutas por outro titulo que não seja o de compra" (BRASIL, 1850). Tem-se como exceção dessa regra aquelas situadas em áreas de fronteiras que poder-se-ia incorrer em doações pelo Império brasileiro.

Esta Lei propõe também a legitimação daquelas terras já adquiridas por meio de posse e de sesmarias que estiverem sendo cultivadas ou com princípio de cultivo, desde que comprovado possuir recursos para cultivá-las. Outro ponto que merece atenção é a preferência aos possuidores de terras na compra de outras novas, em relação àqueles destituídos. Assim como, já traz marcos da mão de obra estrangeira enquanto substitutiva daquela escrava, que só seria abolida cerca de quase 40 anos depois, em 1888. A Lei de 1850 permite aos estrangeiros a aquisição de glebas desde que também comprovados recursos que os permitam nela estabelecer.

Neste sentido, Julio Suzuki (2006) explana sobre os desdobramentos de se criar uma organização na forma de Lei para o acesso a terras, somado à proibição do tráfico negreiro, e à vinda de imigrantes como forma substitutiva do trabalho escravo, visando à Lei Áurea de 1888.

A generalização da terra como mercadoria, a abolição da escravidão e o incentivo à imigração estão vinculados à pressão exercida pela Inglaterra, cujo objetivo era sumariamente expandir seu mercado, bem como garantir preços acessíveis na aquisição de matérias-primas, de que o Brasil era grande exportador (SUZUKI, 2006, p. 215).

É importante enfatizar o que este autor destaca como a importância da pressão inglesa para este contexto de construção do espaço brasileiro. A reconhecida Lei de 08 de agosto de 
1845, conhecida no Brasil como Bill Aberdeen ${ }^{31}$, inaugura oficialmente o que se chama de pressão inglesa sobre a escravatura brasileira. Pressão que vinha sendo exercida através da exigência de que a nação independente fosse construída sobre ombros de trabalhadores livres, desde 1830. Julio Suzuki (2006) destaca o interesse inglês na ampliação de seu mercado, mas há a contrapartida de que a pressão exercida foi fundamental ao fim do tráfico negreiro, expressa pela Lei Eusébio de Queiroz em 1850 e, mais tarde, na abolição da escravidão com a Lei Áurea, em 1888. Ainda que, no limite, tais leis não correspondam, de fato, ao término daquilo reprimido por elas, o que faz com que o termo abolição seja questionado ainda hoje quando se percebe que a cor da pele ainda emerge enquanto signo de sobreposições de corpos.

Aliás, a expressão popular "pra inglês ver" reside neste prolongamento da interrupção oficial do tráfico e, mais ainda, da própria escravatura, a despeito de toda pressão externa.

Assim, podemos afirmar que a Lei de Terras, de 1850, coadunava- se com os ideais mercantilistas do projeto inglês de ampliação de seu mercado, já que o número de consumidores cresceria com a entrada do contingente de escravos negros recém-libertos, bem como os imigrantes, sobretudo de italianos, que ao se monetarizarem também entrariam nesse mercado como consumidores potenciais. (SUZUKI, 2006, p. 215).

Neste sentido, é justificada a importância da Lei de Terras para a gestão de terras públicas, principalmente mediante este cenário no qual o Brasil é conformado enquanto país independente, pautado no Império como forma de governo, e com ideais de progresso grandemente alimentados pelas lavouras de café. A Lei de Terras cria categorias de legitimação ao domínio absoluto, que reside em seu cultivo, em sua medição, em critérios que compõe o seu artigo $5^{\circ}$, a seguir citado:

Art. $5^{\circ}$ Serão legitimadas as posses mansas e pacificas, adquiridas por occupação primaria, ou havidas do primeiro occupante, que se acharem cultivadas, ou com principio de cultura, e morada, habitual do respectivo posseiro, ou de quem o represente, guardadas as regras seguintes:

$\S 1^{\circ}$ Cada posse em terras de cultura, ou em campos de criação, comprehenderá, além do terreno aproveitado ou do necessario para pastagem dos animaes que tiver o posseiro, outrotanto mais de terreno devoluto que houver contiguo, comtanto que em nenhum caso a extensão total da posse

\footnotetext{
${ }^{31}$ Os artigos que compõem esta Lei de 08 de agosto de 1845 podem ser lidos na íntegra no seguinte endereço: http://www.franklinmartins.com.br/estacao_historia_artigo.php?titulo=bill-aberdeen-integra-londres-1845.

Acesso em: 02 de setembro de 2014.
} 
exceda a de uma sesmaria para cultura ou criação, igual ás ultimas concedidas na mesma comarca ou na mais vizinha.

$\S 2^{\circ}$ As posses em circumstancias de serem legitimadas, que se acharem em sesmarias ou outras concessões do Governo, não incursas em commisso ou revalidadas por esta Lei, só darão direito à indemnização pelas bemfeitorias. Exceptua-se desta regra o caso do verificar-se a favor da posse qualquer das seguintes hypotheses: $1^{\mathrm{a}}$, o ter sido declarada boa por sentença passada em julgado entre os sesmeiros ou concessionarios e os posseiros; $2^{\mathrm{a}}$, ter sido estabelecida antes da medição da sesmaria ou concessão, e não perturbada por cinco annos; $3^{\mathrm{a}}$, ter sido estabelecida depois da dita medição, e não perturbada por 10 annos.

$\S 3^{\circ}$ Dada a excepção do paragrapho antecedente, os posseiros gozarão do favor que lhes assegura o $\S 1^{\circ}$, competindo ao respectivo sesmeiro ou concessionario ficar com o terreno que sobrar da divisão feita entre os ditos posseiros, ou considerar-se tambem posseiro para entrar em rateio igual com elles.

$\S 4^{\circ}$ Os campos de uso commum dos moradores de uma ou mais freguezias, municipios ou comarcas serão conservados em toda a extensão de suas divisas, e continuarão a prestar o mesmo uso, conforme a pratica actual, emquanto por Lei não se dispuzer o contrario. (BRASIL, 1850)

No entanto, Benedito Prezia e Eduardo Hoornaert (2000) expõem justamente as consequências dessa Lei de Terras para a construção do espaço brasileiro, já que pode ser percebida sua tendência excludente em relação àqueles despossuídos: fala-se daqueles que não detinham recursos suficientes para que fosse julgado como capaz de cultivar uma terra, o que influencia, portanto, no aumento da propriedade fundiária. "O acesso a terra para a grande maioria do povo brasileiro, que sem opção migrou para os centros urbanos ou tornou-se bóiafria. Outros continuaram no campo como posseiros, numa situação de ilegalidade, sem direito ao título de propriedade" (PREZIA e HOORNAERT, 2000, s.n.t).

Segundo Vitor Amorim de Angelo (2007, s.n.t), houve supressão de propostas contidas no projeto original de 1843 , que seriam do imposto territorial e da expropriação das terras no caso de não serem legalizadas (com registro e demarcação) no tempo de seis meses estimado. Tais propostas foram substituídas por multas que raramente eram pagas, o que demonstra que "as mudanças evidenciaram a força política dos grandes proprietários de terra, especialmente da província fluminense, descontentes com os termos da proposta inicial". Além disso,

Mesmo tendo sido um passo importante na regulamentação da questão fundiária, a Lei de Terras teve pouca consequência prática, com exceção da dificuldade criada para o acesso à terra pelas camadas mais pobres da população e pelos imigrantes, que se viram obrigados a trabalhar nas grandes 
fazendas de café. [...] Na medida em que elevou o preço da terra, exigindo também o pagamento à vista e em dinheiro no ato da compra, a lei n. 601 [Lei de Terras] contribuiu para manter a concentração fundiária que marca a realidade brasileira até hoje (ANGELO, 2007, s.n.t.).

Percebe-se, portanto, que a questão de terras brasileiras está pautada remotamente na estruturação agrária e no arranjo agrícola, priorizando-se o latifúndio e as grandes e monocultoras plantações, como afirma Ângela Almeida (2000). Nelson Nozoe (2006, p. 598) observa que "o acirramento dos conflitos armados e das disputas judiciais entre detentores da terra parece estar na base das normas legislativas de amparo aos ocupantes destituídos dos títulos formais das áreas concedidas a sesmeiros". Este autor observa uma certa confusão na institucionalização das terras feitas em 1850 através da referida Lei de Terras, com aqueles títulos expedidos por sesmarias, na incorporação de Leis do além-mar.

Ao lavrador de parcos recursos, analfabeto e desprovido de meios para influenciar os governantes, convinha a posse das faixas situadas entre os limites das grandes propriedades ou, no caso dos mais audazes, a migração para as paragens mais distantes dos núcleos de povoamento, em demanda de terras que, de tão remotas, ao senhor de fazendas lhe não valia ainda a pena requerer de sesmaria. Desse modo, sem a oposição das autoridades, na prática prevaleciam dois mecanismos: as posses predominavam nas áreas da fronteira econômica, algumas sujeitas a invasões dos índios, já as datas de sesmaria dominavam quase por completo as zonas populosas e com organização administrativa, social e econômica já delineada (NOZOE, 2000, p. 596-597).

Trata-se, de novo, da expressão de duas situações díspares que fomentam a construção do território brasileiro se dando sobre mecanismos estrategicamente desiguais. Os grandes produtores são priorizados por suas terras estarem situadas em centros de abastecimento alimentício e de inserção no mercado, já que corresponde a terras mais populosas e adensadas; e os outros tantos pequenos agricultores, destituídos de recursos, se amontoam no que sobram de terras, geralmente em torno das grandes propriedades e em zonas de fronteiras com outros países, historicamente com ocupações mais permissivas.

Segundo reportagem acerca das consequências dessa Lei de Terras de 1850, Vitor Amorim de Angelo (2007) ressalta que, entre os séculos XVI e XVIII, aquelas Capitanias Hereditárias, anteriormente citadas, foram voltando ao poderio da Coroa por meio do confisco, por causa daquilo que Julio Suzuki (2006) chamaria de "domínio provisório". Tais 
Capitanias Hereditárias depois se transformaram numa espécie de Capitanias Reais, onde a concessão de posse era destinada a certos "fidalgos e religiosos" (ANGELO, 2007, s.n.t.). Neste sentido, destaca-se brevemente que as terras destinadas à construção da Sede do Bispado em Minas Gerais, e que deu origem ao Arraial Nossa Senhora do Carmo, transformado em Vila do Carmo e, posteriormente, em homenagem à mulher Maria Ana do então Rei Português João VI, cidade de Mariana. Estas terras, concedidas à Igreja, hoje guardam, através dos casarios construídos com estética barroca, a memória da jurisdição brasileira no que concerne à forma de acesso e tratamento jurídico.

Explica-se que ao longo do trabalho se utiliza, por vezes, a designação a Igreja para referenciar a Igreja Católica Apostólica Romana. Isto ocorre por conta de sua centralidade na construção do espaço brasileiro, que se expressa a partir de seu papel político, e para além dele. Outras religiões, como a pentecostal, emergiram e reivindicaram a partir da década de 1960 centralidades neste país, que se expressa a partir da transformação - ao menos no papel em Estado laico com a Constituição de 1988. Salienta-se que não se pretende contribuir para a ratificação ou reforço de uma centralidade ao referenciar a Igreja Católica como a Igreja, no sentido de sobreposição qualitativa ou quantitativa de influência religiosa. Não se entra neste mérito. Inclusive, se reconhece que outras manifestações religiosas e culturais - categorizadas em indígenas, africanas, etc - antecedem, convivem e sobrevivem, a despeito desta exaltação. Chamar esta Ordem religiosa de a Igreja é também fazer jus ao modo como os assentados a referenciam. A palavra Igreja é trazida nesta redação com letra maiúscula, quando se pretende referenciar aquela católica, como forma de reproduzir o empacotamento de signos que a ela são designados. Não se trata aqui de um empoderamento de sua Ordem frente a outras Ordens religiosas. Pretende-se tratá-la enquanto uma Instituição que guarda imagens e imaginários que ainda atuam enquanto atores na construção do espaço brasileiro.

Deparou-se com tais imaginários, sobre os quais se explanará no próximo capítulo, que colore a história de luta pelo assentamento com cores oriundas da memória social que se tem da própria atuação histórica da Igreja no território. Por vezes, símbolos incorporados de eventos diversos possuem suas explicações entrecruzadas com aquelas ligadas à história de luta, e isso se estende para outras Instituições, tais como o Estado, a Prefeitura, a EMATER, e o INCRA. Em outras palavras, tais Instituições possuem seus papeis ora destacados, ora atacados a depender de como estes aparentam posicionar-se perante o conflito por estas terras. Percebeu-se um mecanismo de memória que exalta ora o nome daquele que desempenhou um 
papel atuante na história de luta, a despeito desta atuação ter se dado através de uma ação institucional; ora a instituição é mencionada a depender da importância e da profundidade de sua atuação no imaginário dos assentados. Por exemplo, se um membro da ordem religiosa ou política assume um posicionamento distinto daquele que socialmente seria a ele relegado, este membro passa a não ser referenciado enquanto Instituição, e o seu nome é então destacado na história de luta. Neste sentido, tem-se a importância do Valcir enquanto parte do sindicado METABASE. Ao mesmo tempo em que certas ações, quando não evidenciadas, são subestimadas e relegadas às paisagens que se tem acerca daquela instituição, como foram os casos da Igreja, do INCRA, da Câmara, e da Prefeitura Municipal.

Porquanto, no caso da luta pelo Cafundão, os assentados se depararam com uma expressão da complexidade e da sobreposição jurídica que ocorre em Mariana-MG. Isto porque, trata-se de uma vila que emerge de um contexto de formação advindo da mineração, mas o estatuto de ser reconhecida enquanto cidade, em 1745, advém de sua emergência enquanto grande produtora de ouro que coincide também com a sua transformação em polo religioso através de Sede do Bispado. Esta emergência enquanto cidade que abrigaria a Sede do Bispado em Minas Gerais, desmembrando-se da diocese do Rio de Janeiro-RJ, tornou complexo o sistema de posses que hoje impera no local. Se outrora haveria concessões de terras do Reino a essa Ordem Religiosa, pelo contrato da enfiteuse, como se conformaria esse regime de posse passados mais de 300 anos de sua construção? E, mais ainda, passados pouco mais de 100 anos de sua elevação para Arcebispado, compondo a Arquidiocese de Mariana, que abrange cerca de 79 municípios mineiros numa extensão de quase 23 mil km² ${ }^{32}$

Rosa Luxemburgo (1980) lembra da influência de a Igreja ser, historicamente, detentora política, econômica e ideológica de riquezas e patrimônios. Grande parte de todo o imaginário acerca da posse da terra, de fato, e outras posses que ocorrem num nível extrajurídico, é discorrido por Rosa Luxemburgo (1980) como presente na sociedade desde a Idade Média. Isto porque,

Na Idade Média, enquanto a população trabalhadora se afundava em pobreza em conseqüência da escravidão, a Igreja tornava-se cada vez mais rica. Além dos dízimos e de outras taxas, a Igreja se beneficiava, neste período, de grandes doações, legados feitos por ricos libertinos de ambos os sexos que desejavam compensar, no último momento, a sua vida de pecado. Deram e

\footnotetext{
32 Conforme o Guia Geral da Arquidiocese de Mariana (2008-2009), disponível em: http://www.arqmariana.c om.br/guiageral/guia_final.pdf. Acesso em: 10 de novembro de 2014.
} 
voltaram a dar à Igreja dinheiro, casas, aldeias inteiras com os seus servos e algumas vezes rendas de terra ou direitos consuetudinários de trabalho. Deste modo a Igreja adquiriu uma enorme riqueza. Ao mesmo tempo o clero deixou de o ser, para passar a ser o administrador da riqueza que a Igreja tinha recebido. Foi abertamente declarado, no século XII, ao formular-se uma lei que se diz vir da Sagrada Escritura, que a riqueza da Igreja pertence não aos fiéis, mas é propriedade individual do clero e do seu chefe, para o Papa, sobretudo. As posições eclesiásticas, portanto, ofereciam as melhores oportunidades para obter grandes rendimentos. Cada eclesiástico dispunha da propriedade da Igreja como se fosse sua e largamente a doava aos seus parentes, filhos e netos. Por este meio os bens da Igreja foram pilhados e desapareceram nas mãos dos familiares do clero. Por esta razão, os Papas declararam-se como proprietários soberanos das fortunas da Igreja e ordenaram o celibato do clero para o manterem intacto e impedir que o seu patrimônio fosse disperso. O celibato foi decretado no século XI, mas não foi posto em prática até o século XIII, devido à posição do clero. Ainda para impedir a dispersão da riqueza da Igreja, em 1297 o Papa Bonifácio VIII proibiu os eclesiásticos de fazerem oferta dos seus rendimentos aos leigos, sem permissão do Papa. Assim a Igreja acumulou enorme riqueza especialmente em terras lavradas e o clero de todos os países cristãos tornouse o mais importante proprietário de terras. Possuía algumas vezes um terço ou mais do que um terço de todas as terras do país! (LUXEMBURGO, 1980, p. 08).

Em outras palavras, há certa conformação deste poder religioso incrustado na história de construção do espaço. Especificamente no Brasil, se expressa de forma a privilegiar esta ordem religiosa, e mais recentemente algumas outras, em detrimento daquelas que por vezes não possuem a mesma visibilidade ou são até marginalizadas, como aquelas oriundas de culturas conceituadas como indígenas e africanas.

No caso das terras do Cafundão, deparou-se ainda com a posse sendo juridicamente relegada à Igreja, expresso na Paróquia local. A despeito de eles viverem em tais terras por mais de 100 anos, no limite eles não possuíam o direito de posse pois se esbarraria nos contratos da enfiteuse - onde o enfiteuta seria a Igreja. Esta dimensão de que a Igreja possuiria posses (de terras) na região adentra o discurso de que se trata de uma Ordem religiosa que ainda estabelece sua interferência na dinâmica do município, outrora Sede do Bispado e hoje sede da Arquidiocese de Mariana. Como também, diminui a importância de outras ocupações, que não o uso da própria Igreja. A história dos assentados pelo Cafundão se esbarra na desqualificação de suas memórias para com estas terras, já que pertenceria, até a interferência do INCRA, à Paróquia Nossa Senhora da Conceição de Cachoeira do Brumado, 
responsável por esta comunidade ${ }^{33}$. Pertencer à Paróquia significaria a diminuição do direito, por parte daqueles que são hoje assentados, de habitar tais terras, ao mesmo tempo em que abre a contrapartida para que outros atores mais afortunados se apropriem destas tais a título de aumentar sua propriedade. Esta história será mais bem delineada ao longo do trabalho.

Destaca-se, porquanto, que se no século XVIII tais terras foram convertidas para fins de sediar a emergente Ordem religiosa de Minas Gerais, os desdobramentos da criação da cidade de Mariana fez com que este espaço fosse, de fato, construído para além do plano religioso. Neste sentido, em relação às terras da Igreja concedidas pelo Estado, este último vem se comportando ao longo da jurisprudência de forma a garantir e a regularizar aquilo que pertenceria de fato às Ordens religiosas. Ou seja, se coabitavam duas ordens em tempos de exploração das terras chamadas de Brasil, percebe-se que essa relação de poderes foi adquirindo contornos que não necessariamente significaram ser amistosos, mas revelaram-se complementares sob vários aspectos.

Dermi Azevedo (2004, p. 111), ao discorrer sobre o papel político da Igreja Católica no Brasil, destaca que se a "Igreja era uma instituição subordinada ao Estado" haveria a contrapartida de ser considerada a religião oficial e "funcionava como instrumento de dominação social, política e cultural". Este autor destaca também os comportamentos de tal Igreja mediante o cenário político-econômico e até científico predominantes.

O poder estabelecido, no período colonial, promoveu um modelo de Catolicismo, conhecido como Cristandade. Nele, a Igreja era uma instituição subordinada ao Estado e a religião oficial funcionava como instrumento de dominação social, política e cultural. A crise desse modelo é iniciada, simbolicamente, em 1759, com a expulsão dos jesuítas e com a progressiva hegemonia da nova mentalidade racionalista e iluminista. No segundo reinado, em 1840, começa um novo período na história da Igreja no Brasil, conhecido como romanização do Catolicismo, voltado à colocação da Igreja sob ordens diretas do Papa e não mais como uma instituição vinculada à Coroa luso-brasileira (AZEVEDO, 2004, p. 111-112).

Dermi Azevedo (2004) destaca que neste período correspondente ao segundo reinado da Igreja, que vai de 1840 e poderia generalizadamente se estender ao período atual, a Igreja ampliou seu leque de intervenção a partir da preocupação inicial com a formação de seu clero,

\footnotetext{
${ }^{33}$ Usou-se a terminologia comunidade como área de interferência e administração da Paróquia local, por conta de percebê-la como categoria comum de referência em documentos eclesiais, tal como no Jornal o Arquidiocesano.
} 
a posterior experiência da Proclamação da República e seu aparente desligamento para com o Estado e, desde a década de 1930, adentrou a arena política buscando visibilidade e status quo. "A Constituição de 1934 registra alguns resultados dessa ofensiva, tal como a instituição do ensino religioso nas escolas públicas, a presença de capelães militares das Forças Armadas e a subversão estatal para as atividades assistenciais ligadas à Igreja” (AZEVEDO, 2009, p. 112).

É importante ressaltar que a Constituição de 1824, em que se institui o Império do Brasil e se formata um Estado brasileiro independente, poderia produzir um suposto desligamento deste em relação à Igreja e aos Ordenamentos. Porém, esta relação é muito mais profunda e vai além de aspectos formais presentes numa jurisdição. Até a criação de órgãos específicos à gestão do território, a Igreja era quem detinha as informações referentes à posse das terras e aos registros de nascidos, falecidos, matrimônios, heranças, além do próprio batismo. Julio Suzuki (2006) destaca a centralidade dos dados construídos e mantidos pela Igreja como única forma de registro, até que outros pudessem ser sistematizados.

\begin{abstract}
A Lei $N^{\circ} 601 / 1850$, a Lei de Terras, vem legitimar a mercantilização da terra como única forma de aquisição, bem como as posses anteriormente existentes, sendo que, para a realização da titulação, o Estado, que estava em formação, utilizou-se da única informação possível que garantisse a efetiva ocupação das terras: o registro paroquial. (SUZUKI, 2006, p. 215, grifos nossos).
\end{abstract}

Acerca do registro paroquial citado pelo autor, cabe aqui um destaque. O Registro Paroquial de Terras - RPT, realizado pela Ordem religiosa cristã, serviu como meio de regulamentar as posses que foram concedidas em regime de sesmarias, para atender ao propósito de regulamentação prevista na Lei de Terras de 1850 . Por meio do Decreto $\mathrm{n}^{\circ} 1.318$, de 30 de janeiro de 1854, ficam instituídas as regras e premissas ao registro da terra, bem como elenca a Igreja como aquela que convergirá tais informações, como pode ser lido em seu artigo 97, do Capítulo IX acerca “Do registro das terras possuídas”.

Art. 91. Todos os possuidores de terras, qualquer que seja o titulo de sua propriedade, ou possessão, são obrigados a fazer registrar as terras, que possuirem, dentro dos prazos marcados pelo presente Regulamento, os quaes se começarão a contar, na Côrte, e Provincia do Rio de Janeiro, da data 
fixada pelo Ministro e Secretario d'Estado dos Negocios do Imperio, e nas Provincias, da fixada pelo respectivo Presidente.

[...]

Art. 97. Os Vigarios de cada huma das Freguezias do Imperio são os encarregados de receber as declarações para o registro das terras, e os incumbidos de proceder á esse registro dentro de suas Freguezias, fazendo-o por si, ou por escreventes, que poderão nomear, e ter sob sua responsabilidade. (BRASIL, 1854)

Em um site de consultoria jurídica ${ }^{34}$, há o relato de um caso que demonstra o quão confuso, complexo e atual é esta questão de posse no Brasil. Porém, demonstra como passa a ser considerada a forma de registro paroquial que perde legitimidade no cenário em que a comprovação judicial se dá sob outros critérios e arranjos. Segundo a reportagem, em 1990 houve o pedido de "reconhecimento de domínio pleno", que aqui seria o domínio absoluto, de um ocupante da Ilha João da Cunha, localizada em Porto Belo, no estado de Santa Catarina. Tal ocupante possuía o registro paroquial da Ilha e requereu que fosse considerada a sua titularidade. Recusado o pedido, ele insistiu que a necessidade de medição da Ilha seria somente para as terras continentais, logo, estaria havendo uma desconsideração do que a Lei de Terras previa. O ministro do Supremo Tribunal Federal ressaltou que ele descumpriu não somente a necessidade de medição, como também a exigência de publicidade e de outros critérios, por este motivo sua cadeia dominial não estaria completa.

Segundo o relator, o registro paroquial não tem o poder de atribuir o domínio ao ocupante da terra, pois não confere publicidade aos registros. O relator destacou que a origem das propriedades particulares no Brasil parte das doações de sesmarias e de ocupações primárias. Portanto, para se transformar em domínio pleno, deveriam essas terras passar por uma revalidação ou legitimação, conforme previsto na Lei de Terras. Ressaltou que, para tal legalização, seria necessário, além da medição, o cultivo da terra, a moradia habitual do respectivo posseiro, bem como as demais condições exigidas no artigo $5^{\circ}$ da lei (CONSULTOR JURÍDICO, 2009).

Contudo, apesar do registro paroquial não servir de comprovação única e exclusiva, e em alguns casos ser considerado insuficiente, tais dados fornecem indícios de como se dava a construção do espaço naquele período específico. Sobretudo, em tempos em que não havia

\footnotetext{
${ }^{34}$ Vide: CONSULTOR JURIDICO. Registro paroquial não comprova posse de terras. Caderno Propriedade púbica. 25 de junho de 2009, 02h07. Disponível: http://www.conjur.com.br/2009-jun-25/registro-paroquial-naocomprova-posse-terras-uniao. Acesso em: 28 de agosto de 2014.
} 
sido criadas as instituições formais que sistematizam dados específicos, tal como o Instituto Brasileiro de Geografia e Estatística - IBGE, criado oficialmente em 1936, mas que foi desdobrado de duas instituições anteriores que reside na Diretoria Geral de Estatística em 1871 e, com competências mais aproximadas daquelas exercidas hoje, no Instituto Nacional de Estatística - INE, em 1934. No que concerne à questão fundiária, cita-se a criação do Instituto Nacional de Colonização e Reforma Agrária - INCRA, a partir do Decreto 1.110 de 09 de julho de 1970, e que foi desdobrado de duas instituições anteriores datadas de 1964, que seriam o Instituto Brasileiro de Reforma Agrária - IBRA, e o Instituto Nacional de Desenvolvimento Rural - INDA.

Neste sentido, é evidente o papel político da Igreja não somente na evangelização e no controle social e moral da sociedade, mas como também na própria responsabilidade por construir dados de recenseamento, tais como mortes, vendas de escravos, gestão de patrimônios na forma de casas, terras, ouro e escravos. Na história de construção do espaço brasileiro, deve-se sempre buscar tais desdobramentos políticos de religiosos na medida em que Estado e Igreja, por vezes, se associaram. Ressalta-se que será mais bem analisada a questão de terras do Cafundão, as quais pertenceram à Igreja, antes de serem negociadas e compradas pelo INCRA. Para além de detentora de tais terras, o alcance ideológico do exercício de propriedade que a Igreja dispõe especialmente sobre esta cidade será analisada, no próximo capítulo, à luz das narrativas dos assentados.

\subsection{Reforma agrária: construção e atribuição de significados.}

Porquanto, pretendeu-se, até aqui, elucidar sobre a construção deste país no contexto das desigualdades de acesso a terra, que dialogam com outras formas de segregação: de corpos, de direitos, de manifestações culturais, religiosas e outras tantas. Pretendeu-se explanar sobre a Lei de Terras como forma de institucionalizar esta desigualdade, dificultando o acesso àqueles que não detinham recursos para defender que nela poderia se estabelecer e, mais ainda, impediam o acesso às camadas populares, tais como os pobres, os escravos, os descendentes destes escravos - forros ou libertos.

Percebeu-se, até o momento, que o Estado atua como grande motivador e fundamentador de toda esta desigualdade, na medida em que suas pretensões até aqui 
revelam-se de forma estrita à ocupação de terras e ao privilégio por aqueles que poderiam gerir a terra e que detinham recursos à extração de minerais e à agropecuária. Este cenário, conforme será visto, irá perdurar até a conformação, de fato, do termo reforma agrária e a intensificação da pressão social pela terra, que se dá de forma consoante ao aumento da população, ao valor da terra e à forma espacial de uso e ocupação que aprofunda segregações entre regiões brasileiras - e isto por volta da década de 30 do século XX. Neste sentido, indaga-se: quando é que o termo reforma agrária se gesta e adentra o cenário político e social brasileiro?

Segundo Mary Del Priore e Renato Venâncio (2006b, p. 192), os confrontos armados e a rebeldia que perpassa o campo brasileiro, até meados do século $\mathrm{XX}$, não possuíam ainda vínculos com a expressão reforma agrária, a despeito de haverem relação prática por meio do reconhecimento da estrutura fundiária desigual, de relacionarem a escravatura como incentivadora desta desigualdade e de, por vezes, reclamarem por reformas sociais, inclusive em seu aspecto fundiário. Para estes autores, a expressão reforma agrária se difundiu somente com a Revolução Francesa, em 1789, com junção destes dois termos - reforma e agrária sendo usados para expressar a extensão dos princípios de "igualdade, liberdade e fraternidade", àquilo que se chamaria de mundo rural ou campo. Antes disso, estes termos aparecem em separado nas línguas e não expressam a inquietação por reestruturações, principalmente aquelas que concernem ao campo. Como se verá, a expressão enquanto representativa de requisições sociais específicas adentrará o contexto brasileiro somente na segunda metade do século XX.

Mary Del Priore e Renato Venâncio (2006b) elucidam que a reivindicação por uma reforma social se evidencia na história brasileira a partir do final do século XVIII, quando “Luis dos Santos Vilhena refere-se à necessidade de uma 'lei agrária', que distribuísse terras. Durante a campanha a favor da abolição da escravidão, embora o termo 'reforma agrária' não fosse utilizado, a proposta adquire base social” (2006b, p. 194). Ou seja, a crítica ao latifúndio estava presente em campanhas pró-abolição, pois passa a ser relacionado aos problemas sociais, aos problemas inerentes à escravatura e à necessidade de se empreender aquilo chamado de reforma social e a distribuição de terras, a despeito da expressão reforma agrária ainda não vigorar neste momento. Inclusive, Joaquim Nabuco (1883, p. 58) em seu livro O Abolicionismo datado de 1863, que é uma campanha contra a escravatura, faz uma critica ao Brasil chamando-o de atrasado, grandemente por conta da própria escravatura ainda em voga 
e das relações que ocorrem na terra que se dão sob o molde de velhas hierarquias de tratamento e de acesso.

Foi essa população que se foi internando, vivendo como ciganos, aderindo às terras das fazendas ou dos engenhos onde achava agasalho, formando-se em pequenos núcleos nos interstícios das propriedades agrícolas, edificando as suas quatro paredes de barro onde se lhe dava permissão para fazê-lo, mediante condições de vassalagem que constituíam os moradores em servos da gleba.

Para qualquer lado que se olhe, esses efeitos foram os mesmos. Latifundia perdidere Italian, é uma frase que soa como verdade tangível aos ouvidos do brasileiro. Compare por um momento, quem viajou nos Estados Unidos ou na Suíça, o aspecto do país, da cultura, da ocupação do solo pelo homem. Diz-se que o Brasil é um país novo; sim, é um país novo em algumas partes; virgem mesmo, mas em outras é um país velho; há mais de trezentos anos que as terras foram primeiras desbastadas, as florestas abatidas, e plantados os canaviais (NABUCO, 1883, p. 58).

Joaquim Nabuco (1883) explana que a quebra do que chama de monopólio da terra haveria de ser empreendida para que os escravos não possuíssem a miséria como resultante da abolição. A reforma social acompanhada do abolicionismo atenderia ao projeto de evitar que a escravatura se reproduza sob novos moldes, através do que o autor denomina como servo da gleba. O que se aproxima da ideia de José de Souza Martins (1990) para quem as formas de sujeição através do trabalho, mascarado pelo salário, fomentam o "cativeiro da terra". Neste sentido, Joaquim Nabuco (1883) afirma que a força daqueles que detém o monopólio advém das formas de escravidão e da manutenção de poder. Quanto aos escravos - e também aos demais miseráveis brasileiros - restava a inquietude da situação de estar segregado, sobrepujado, sobreposto.

Nenhuma opinião remotamente distante do governo pode ostentar o pessoal numeroso dos dois partidos que se alternam no exercício do patronado e na guarda do cofre das graças, distribuem empresas e favores, e por isso têm em torno de si, ou às suas ordens e sob seu mando - num país que a escravidão empobreceu e carcomeu -, todos os elementos dependentes e necessitados da população. Isso mesmo caracteriza a diferença entre o abolicionismo e os dois partidos constitucionais: o poder destes é, praticamente, o poder da escravidão toda, como instituição privada e como instituição política; o daquele é o poder tão somente das forças que começam a rebelar-se contra semelhante monopólio - da terra, do capital e do trabalho - que faz da 
escravidão um estado no Estado, cem vezes mais forte do que a própria nação (NABUCO, 1883, p. 08).

Aliás, será preciso enfatizar o contexto de surgimento da cidade de Mariana-MG que se deu a partir da exploração de ouro por meio de mão de obra escrava. Tarcísio Rodrigues Botelho (2000) conclui que em vilas pertencentes à região mineradora, pautada na exploração de ouro no século XVIII, havia uma relação entre concentração de escravos e de terras, onde grandes proprietários fundiários possuíam no mesmo sentido um maior número de escravos ${ }^{35}$. Outro dado que ele traz reside no tamanho das propriedades de terra ser maior quando localizadas de forma afastada aos centros das vilas, e menores quando localizadas no interior da vila. Já se enuncia neste espaço-tempo uma dinâmica espacial diferenciada em terras urbanas e naquelas terras dedicadas à agropecuária e à mineração, pautadas no trabalho braçal intensivo de escravos.

Neste sentido, Angelo Alves Carrara (1999, p. 05) contribui ao estudo acerca da ocupação do solo em Minas Gerais a partir "das cartas de sesmarias concedidas entre 1674 e 1739, e nas escrituras de compra e venda de imóveis rurais registradas no notariado da vila de Mariana, entre 1711 e 1714". Este estudo contribui ao entendimento da historicidade da ocupação de terras pertencentes ao estado de Minas Gerais e à Vila (posteriormente, cidade) de Mariana-MG, por meio das duas principais vias de acesso a terra, que foram discutidas anteriormente, que reside na concessão de sesmarias e na compra e venda de imóveis rurais. Neste contexto, emerge o histórico de ocupação do município de Mariana. O seu início se deu a partir da existência de pequenos povoados que compuseram o que se denominou de arraial Ribeirão do Carmo, e que depois foram incorporados ao centro-planejado, com ruas com traçados paralelos e praças retangulares ${ }^{36}$. De forma concomitante à ocupação na área que

\footnotetext{
${ }^{35}$ Este autor ressalta que os dados referentes à Vila do Carmo (então cidade de Mariana) foram encontrados de forma confusa e por vezes conflitantes. Por conta disso, debruçou-se também sobre a Vila Rica (Ouro Preto), São João Del Rey e Sabará.

36 “O termo de Vila do Ribeirão do Carmo/Mariana era mais extenso que o termo de Vila Rica, possuía um número maior de freguesias, além de ser mais populoso. Abrangia os sertões do Rio Pomba, Muriaé e Doce, atingindo as fronteiras do Rio de Janeiro. Era uma região que apresentava um quadro natural diverso, possibilitando uma ampliação econômica e abrigava áreas mineratórias, agrícolas e regiões ainda intocadas. Descobertas importantes foram sendo realizadas nas proximidades do Ribeirão do Carmo e, 'preocupados, pois, em matar a fome, e em fazer as roçadas para mantimentos, os primeiros moradores do Carmo se espalharam já ao longo do ribeirão' e também dos seus afluentes, iniciando, assim, 'as mais antigas fazendas do Carmo, do Gualaxo do Norte e do Gualaxo do Sul', entre os anos de 1697 e 1698 [...]. As [nove freguesias de Mariana eram]: Antônio Pereira, Camargos, Catas Altas do Mato Dentro, Furquim, Guarapiranga, Inficionado, São Caetano, São Sebastião e Sumidouro, e 15 arraiais subordinados." (PIRES, 2012, p. 28). Sendo que ainda hoje este número permanece, mas os distritos são: Santa Rita Durão, Monsenhor Horta, Camargos, Bandeirantes
} 
viria a ser a sede do município, outros vários povoados foram se estabelecendo de forma circundante num raio de $50 \mathrm{~km}$ em relação ao centro da cidade de Mariana, através de concessão de sesmarias, ocupação inicial de religiosos, e venda de imóveis rurais (FONSECA, 2012). Aliás, esta forma de ocupação traduz a relação histórica entre a concentração de fazendas e o índice de concentração de escravos, forros e libertos no distrito de Cachoeira do Brumado, que correspondiam a cerca de $40 \%$ do total do município de Mariana, em 1830, segundo os dados do PopLin Minas (s.t.n.).

Porquanto, Mary Del Priore e Renato Venâncio (2006b, p. 194) afirmam que Joaquim Nabuco inspirou-se para construir seu O Abolicionismo nas "propostas constitucionais de José Bonifácio”, em 1883. Na Assembleia Constituinte ocorrida em 1823, o Príncipe Regente do Brasil Dom Pedro convocou-a com a principal intenção de elaborar uma Constituição que regesse o Brasil, que era então independente de Portugal. José Bonifácio como ministro do Império atuou enquanto conciliador dos dois partidos que surgiram - partido português e partido brasileiro. Esta conciliação culminou naquela estruturação de poder, já comentada no capítulo anterior, que possui a Assembleia Geral e o Imperador, mas mantém a primeira subordinada ao segundo. Contudo, durou pouco, já que o Imperador dilui a Assembleia. Cabe salientar neste caso que o direito ao voto estava intimamente relacionado à quantidade de alqueires de terra que cada um possuía, o que revela a presença de uma elite agrária nas decisões de cunho jurisdicionais e, inclusive, discutindo propostas acerca da reforma social.

As propostas constitucionais de José Bonifácio que inspiraram Joaquim Nabuco foram sistematizadas num livro chamado Projetos para o Brasil (ANDRADA e SILVA, 1840), no qual há uma seção dedicada à escravatura. $\mathrm{O}$ artigo 10 é revelador da postura que se assume frente a uma necessária reforma social e distribuição de terra. Este artigo defende que "Todos os homens de cor, forros, que não tiverem ofício ou modo certo de vida, receberão do Estado uma pequena sesmaria de terra para cultivarem, e receberão, outrossim, dele os socorros necessários para se estabelecerem, cujo valor irão pagando com o andar do tempo" (ANDRADA e SILVA, 1840, p. 69).

Contudo, Mary Del Priore e Renato Venâncio (2006b), ressaltam que as ambições de José Bonifácio abarcam somente os libertos e que, em 1863, Joaquim Nabuco estende também aos escravos.

(Ribeirão do Carmo), Padre Viegas (Sumidouro), Cláudio Manoel, Furquim, Passagem de Mariana, Cachoeira do Brumado. 
A abolição seria preparada durante duas décadas. Caberia ao Estado: 'A transição por meio da educação do escravo; desenvolver o espírito de cooperação; promover indústrias; melhorar a sorte dos servos da gleba; repartir com eles a terra que cultivam'. Ao longo da década de 1880, em uma série de artigos publicados em jornais cariocas e depois reunidos no livro $A$ campanha abolicionista, José do Patrício define este conjunto de medidas como uma reforma social. (DEL PRIORE e VENÂNCIO, 2006b, p. 194, grifos dos autores).

Mas uma das inúmeras concordâncias que chama a atenção é que, ambos, José Bonifácio Andrada e Silva (1840) e Joaquim Nabuco (1883), criticam a cultura da cana por esta contribuir para a manutenção dos latifúndios pautados na monocultura. Além disso, já se vislumbrava a substituição de outras culturas pela plantação de cana, além da crítica às formas de trabalho subumano e escravo neste tipo de lavoura.

[...] a cultura da cana tem sido muito prejudicial aos povos: 1) porque tem abandonado ou diminuído a cultura do milho e feijão, e a criação dos porcos; e estes gêneros têm encarecido: assim como a cultura do trigo, e a do algodão e azeites de mamona. 2) porque tem introduzido muita escravatura, que não só empobrece aos lavradores, corrompe os costumes e caridade cristã, mas faz mais preguiçosos os mestiços e mulatos, que acham desprezo de puxar pela enxada. 3) porque tem devastado as belas matas e reduzido a taperas muitas herdades. 4) porque rouba muitos braços à agricultura, que se empregam no carreto dos africanos. 5) porque exige grande número de bestas muares que não procriam e que consoem muito milho. 6) [ilegível], 7) porque diminuiria a feitura da cachaça que não prejudicial é do moral e físico dos moradores do campo. (ANDRADA e SILVA, 1840, p. 181)

Percebe-se, portanto, que os ideais do abolicionismo contribuíram para arquitetar um pensamento que condena a estrutura fundiária brasileira e, mais ainda, as relações de hierarquia que se dão na terra. Pensamento este grandemente influenciado pelos ideais do comunismo e do socialismo, conforme destacam Del Priore e Venâncio (2006b, p. 194) ao ratificar a importância simbólica da Comuna de Paris, em 1871, para a popularização em escala mundial destes termos, e que "não demorou muito para que surgissem entre nós pessoas que se interessavam em divulgar tais projetos".

A partir deste momento, as inquietações sociais que receberam um pano de fundo ideológico puderam ser sistematizadas e partidarizadas. Reclamações por reformas sociais ganham vulto de forma concomitante ao surgimento da indústria, e as relações de trabalho que 
calcam esta indústria são também debatidas. O cenário é propício ao surgimento e à força política do sindicato. Conforme apresentado no capítulo anterior, Paul Singer (2009) destaca a importância da industrialização ao surgimento dos sindicados, e que isso se prolifera no Brasil em fins do século XIX e início do XX. Inclusive, as áreas de maior industrialização abarcam proporcionalmente um número maior e mais concentrado de sindicados da categoria, conforme verifica Amir de Paula (2009).

No Brasil, o início do século XX é marcado também pela fundação do Partido Comunista do Brasil (PCB) que, segundo Del Priore e Venâncio (2006b, p. 195), traz para o debate a expressão reforma agrária sistematizada enquanto projeto, grandemente inspirado na Revolução Soviética de 1917, a qual distribuiu terras a camponeses. Estes autores reforçam que a partir deste momento, há uma espécie de associação entre reforma agrária e distribuição de terras enquanto etapas de um processo pela reforma social. "Oferecer terras a quem não as tinha torna-se parte integrante das estratégias políticas de mobilização das massas rurais. [...] O assunto, como é possível perceber, politiza-se". Ou seja, a politização do termo reforma agrária passa a lhe angariar significados em torno de seu eixo central que é a distribuição de terras e a significar etapa de uma reforma social. Além disso, esta expressão também passa a representar imaginários em torno do direito a terra, por parte de quem luta por ela, por aqueles que possuem terras, e os brasileiros que começam a lidar com o que se divulga sobre a reforma agrária.

O termo reforma agrária torna-se presente no cenário político e serve como bandeira de defesa de uma questão eminentemente social aos partidos políticos. Além dessa face de etapa à reforma social, ela passa a ser encarada enquanto oportunidade de aumento da produção de alimentos e também da possibilidade do consumo do próprio produto industrial. Distribuir terras é garantir a manutenção e o aumento da produtividade da terra em seu aspecto agrícola, além de possibilitar que o produto industrial adentre o mercado rural pelo consumo. Segundo Del Priore e Venâncio (2006b),

Havia [...] aqueles que defendiam a medida do ponto de vista técnico e econômico. A reforma agrária seria um estímulo à industrialização. Segundo essa interpretação, distribuir terras, além de favorecer a produção de alimentos - e, consequentemente, possibilitar salários industriais mais baixos -, estimularia o consumo de produtos industriais entre a população rural. Isso, aliás, explica por que vários países capitalistas também fizeram 
reformas agrárias, como foram os caos do Japão (1945) e da Itália (1950). (DEL PRIORE e VENÂNCIO, 2006b, p. 195).

Essa face de incentivo à produtividade e ao consumo perdura ainda hoje no discurso de defesa da reforma agrária. O consumo é, por vezes, associado a uma melhora na qualidade de vida. Torna-se, portanto, medida mitigadora de incentivo à pequena produção, assim como garante a manutenção de uma estrutura agrária que prioriza a agroexportação. Porém, a noção de aumento da produtividade e incentivo à industrialização estava presente nos levantes populares do início do século XX. Foram com fundamentações comunistas e socialistas que se construiu uma ideia da luta contra o imperialismo. Neste sentido, Del Priore e Venâncio (2006b) destacam que os países ditos desenvolvidos estimularam reformas agrárias através de uma apropriação técnica e econômica do programa de reforma agrária, com cujo objetivo fundamental abarcaria a ampliação do lucro através do aumento da produtividade e do mercado consumidor, e talvez por isso seja questionável sua abrangência social ou sua aproximação com a reforma social, de fato.

Conforme pode ser verificado em Prestes (1935), a reestruturação agrária traduz um caminho à reforma social, que se daria através da instituição de um governo popular, da distribuição de terras de latifúndios aos camponeses, e do incentivo à industrialização ao aumento do consumo. Esta industrialização beneficiaria e humanizaria os empregos dos operários que não disputariam entre si pelos postos de trabalho, além de garantir o consumo dos produtos pelos camponeses, que aumentariam a sua produção de alimentos à cidade. Além disso, Prestes (1935) ainda menciona um programa de unificação política e administrativa do Brasil pautado no tratamento igualitário entre as regiões, de forma a não privilegiar uma em detrimento de outra, fazendo-se representar através das Ligas Camponesas do nordeste.

Porquanto, a partir da partidarização do termo reforma agrária, há uma face desta enquanto etapa da reforma social que descortina, inclusive, as histórias de fundação de partidos políticos e de movimentos sociais, porque ela passa a ser empreendida através de pressões sociais. Neste sentido, a história de fundação do partido político mais antigo do país seria interessante de ser analisada, ainda que brevemente. Fala-se do Partido Comunista do Brasil, que por pressões políticas, busca da legalidade e acusações de se tratar de um partido estrangeiro - por conta de sua sede na capital da Rússia - passa a se chamar Partido Comunista Brasileiro, e por isso a sigla é PCB. Há de se enfatizar que o Partido Comunista do 
Brasil (PCdoB) é um desmembramento mais atual desse partido inicial PCB, depois da mudança do nome, mas que continua numa linha evidente de defesa dos ideais de comunismo e socialismo.

De forma sucinta, segundo a sua página oficial de internet ${ }^{37}$, o Partido Comunista do Brasil foi criado em 1922, já com a conhecida imagem do entrecruzamento da foice e do martelo que simboliza a aliança operário-camponesa. Como já discutido, a problematização das relações que se dão na terra é politizada e partidarizada, havendo também a sua sindicalização. Por este motivo, a historicidade da conformação agrária-agrícola brasileira torna-se cada vez mais complexa de ser analisada, com cada vez mais elementos, por que a discussão passa a se tornar presente e a ser construída como necessária - a despeito de poder se questionar se houvera, na mesma medida, a resolução efetivamente agrária-agrícola, ou se somente trata-se de formas graduais de mitigar essa tensão.

Ainda segundo sua página oficial, o PCB foi registrado em março de 1922 com o nome de Partido Comunista - Seção Brasileira da Internacional Comunista (PC-SBIC), o que nutriu as acusações que sobreviram de que se tratava de um partido estrangeiro, mediante um cenário em que este partido ganha relevo e bancada nas esferas governamentais. Neste sentido, as acusações traduzem estratégia de depor, cassar, tornar ilegível e intimidar os que adentram a arena política com bandeiras operárias, camponesas, falando à juventude e sob o lema de "Pão, Terra e Liberdade". Este lema, que é lembrado em reportagem ao Brasil de Fato (2010) pela Anita Leocadia Benário ${ }^{38}$ - filha de Olga Benário e Luiz Carlos Prestes - é o da Juventude Comunista Carlos Lacerda, que é uma força progressista da Aliança Nacional Libertadora (ANL) criada pelo PCB, que teve como um dos dirigentes o Luiz Carlos Prestes. Em 1945, Luiz Carlos Prestes luta pela legalização do PCB e ganha como senador mais votado da República. Há a sua cassação em 1948 e sua posterior e consequente atuação, portanto, na ilegalidade. Os casos subsequentes pelos quais passaram Luiz Carlos Prestes se relacionam ao que diversos outros atuantes políticos, que se alinhavam a esta ideologia, vivenciaram num país que contém ditaduras em sua historiografia: prisão, torturas... Quando sobrevive, exílio, se se sobrevive para vivenciar, anistia política... Retorno ou não ao Brasil. Lembranças do que viveu até o último respiro.

Pode ser percebido através do Manifesto da Aliança Nacional Libertadora, escrito por Luiz Carlos Prestes (1935) antes de se tornar senador pelo PCB, que esta organização política

\footnotetext{
${ }^{37}$ Disponível em: www.pcb.org.br. Acesos em: 13 de novembro de 2014.

${ }^{38}$ Disponível em: http://www.brasildefato.com.br/node/5093. Acesso em: 13 de novembro de 2014.
} 
se tratou de uma mobilização de intelectuais, que conheciam e disseminavam ideais comunistas e socialistas, como também de militares, a fim de apoiar, sustentar e dar corpo a manifestações populares contra injustiças sociais. Em 1935, ano de escrita do Manifesto, nele consta o chamado para que se continue tendo força, já que contavam com 13 anos de luta empreendida. Desta forma, esta organização política começou a atuar na década de 20 do século XX, e os seus objetivos se relacionam amplamente à luta a favor do que chamam de liberdade do povo e contra o imperialismo, que é a influência de outros países na gestão nacional e a dedicação do país à exportação, enquanto a miséria predomina internamente. Este movimento também possui enquanto objetivos a busca pela integração nacional e equidade de tratamento na gestão regional do país. Assim como, a luta contra as injustiças sociais e estrutura agrária que julgavam arcaica sobre a qual estava se construindo o Brasil.

As lutas continuam - São 13 anos de lutas cruentas, de combates sucessivos e vitórias seguidas das mais negras traições, ilusões que se desfazem, como bolhas de sabão, ao sopro da realidade!

Mas as lutas continuam, porque a vitória ainda não foi alcançada e o lutador heróico é incapaz de ficar a meio do caminho, porque o objetivo a atingir é a libertação nacional do Brasil, a sua unificação nacional e o seu progresso e o bem-estar e a liberdade de seu povo e o lutador persistente e heróico é esse mesmo povo, que do Amazonas ao Rio Grande do Sul, que do litoral às fronteiras da Bolívia, está unificado mais pelo sofrimento, pela miséria e pela humilhação em que vegeta do que uma unidade nacional impossível nas condições semicoloniais e semifeudal de hoje! (PRESTES, 1935, p. 01).

É antecipado, através deste Manifesto, aquilo que Del Priore e Renato Venâncio (2006b, p. 196) apontam como “o primeiro e único levante comunista no Brasil”, ou Intentona Comunista. Luiz Carlos Prestes (1935) diz que os próximos dias seriam decisivos para esta luta que já empreendem contra o que já se apontou como estopim - que reside amplamente na manutenção das hierarquias urbanas e rurais -, só que ataca diretamente também o governo de Getúlio Vargas em voga, ou seja, o primeiro de seu mandato que vai dos anos 1930 a 1945. Acusa o governo de Getúlio Vargas de aliar-se a oposicionistas, através de manobras e traições. Como também, lembra que todas as propostas ligadas à reforma social, ao discurso de distribuição de terras, desapropriação de latifúndios, e à luta contra o imperialismo foram esquecidos por este governo em atuação há cerca de cinco anos, já que foi escrito em 1935. E por isto convocam a todos os brasileiros ao levante. 
O mencionado governo Vargas (1930-1945) passou a ser conhecido como perpetuador do nacionalismo e do populismo, a ponto de conseguir instaurar a ditadura do Estado Novo, a partir de 1937, dois anos após o levante convocado por Prestes (1935). Aliás, Prestes (1935) convoca a todos os "soldados" do Brasil, com destaque para aqueles do Rio Grande do Sul, a quem os chama de "herdeiros das melhores tradições revolucionárias da terra gaúcha"; de Minas Gerais enquanto "terra tradicional das grandes lutas pela democracia"; convoca os nortistas e nordestinos, em especial "ao camponês de todo Brasil, lutador do sertão do nordeste". E este chamado corresponde às principais ações desta tentativa de instaurar um governo dito revolucionário popular, conforme exemplificado por Del Priore e Renato Venâncio (2006b) que destacam os conflitos que ocorreram, com mortes, em Natal, Recife, e Rio de Janeiro. Além disso, estes autores ressaltam que estes conflitos revelam uma associação existente entre a revolução comunista e aquilo que passou a ser chamado de reforma agrária, que se torna comum no discurso e na historicidade de construção do espaço brasileiro. Esta associação feita de forma física e ideológica, na medida em que aqueles comunistas que necessitaram fugir dos centros urbanos, que se tornaram territórios das ações do levante e da disseminação de ideais, mas também de perseguições; iam refugiar-se em áreas mais distantes e rurais, inclusive no sertão nordestino de onde eclodiu, cerca de 20 anos após o Manifesto escrito por Prestes (1935), as chamadas Ligas Camponesas. Neste sentido, a fundamentação das Ligas Camponesas - criada pelo PCB em defesa da reforma agrária e da melhoria do campo - gestou-se anos antes, já que o sertão nordestino tornou-se também território da inquietação de injustiças sociais e de fusão de ideais comunistas.

Mas este levante comunista, que foi também uma revolta de segmentos militares, é reprimido pelo governo em voga, com a instauração, inclusive, do Estado Novo. Esta fase inaugura um momento em que predomina o discurso da seguridade nacional ${ }^{39}$ com o combate ao avanço do comunismo enquanto ameaça à integridade e à ordem do país, conforme avaliado anteriormente. A partir deste momento, torna-se facilitada e justificada a deslegitimação, criminalização e perseguição de organizações políticas que questionam as injustiças sociais, tais como os partidos políticos com inclinação comunista e socialista e os sindicados que nasciam com o advento da industrialização. Momento que também é terreno

\footnotetext{
${ }^{39}$ O discurso de seguridade nacional compõe o cenário de construção do novo projeto político-econômico de um Estado que se impõe à nação, através do poder e da articulação do território, conforme trabalhado por Costa e Steinke (2014) e Costa e Suzuki (2012).
} 
fértil para a intensificação da pressão social enquanto inquietação mediante as desigualdades sociais que se tornavam cada vez mais evidentes.

A ampla história de inserção do PCB, e outros partidos com a mesma fundamentação ideológica, na política brasileira é marcada por cassações e a busca por legitimação. Não se almeja adentrar este diálogo que se tornaria exaustivo com a citação de inúmeros eventos, partidos e nomes daqueles que foram candidatos e eleitos a deputados, senadores e demais cargos políticos em todas as esferas, e que foram cassados e perseguidos. Assim como, não se tem pretensão de esgotar aqui a História do Brasil em termos de remontar a eventos julgáveis necessários de apreciação, como a entrada de Getúlio Vargas em 1930, após a derrubada daquilo conhecido como República Velha, ou o destaque a suas ações que caracterizam a versão de ser populista e nacionalista relacionados ao discurso de integração nacional e às medidas de cunho social e trabalhistas, que atenderam também a oligarquias rurais e urbanas.

Pretende-se dedicar a um debate sobre as questões que coinfluenciaram a conformação da reforma agrária enquanto política nacional. Para Del Priore e Venâncio (2006b), algumas medidas tomadas por Getúlio Vargas, tais como a criação da regulamentação trabalhista que culminou na Consolidação das Leis de Trabalho - CLT, do salário mínimo, da Justiça do Trabalho, da Carteira Profissional, das férias remuneradas; caracterizam um processo de construção de conteúdo político do termo reforma agrária, a despeito de ainda não se poder dizer que ele empreendeu tal ação.

Neste momento, há o processo fundamental de industrialização e urbanização que influenciou o advento das hierarquias urbanas e as relações na terra ganham evidência para serem criticadas. As ações de Getúlio $\operatorname{Vargas}^{40}$, apesar de terem sido fundamentais ao universo trabalhista, se inserem no rol daquelas com apelo tecnicista e economicista que vê na reforma agrária uma oportunidade de ampliar a produtividade da terra e o consumo brasileiro, através de uma estruturação agrária pautada no Complexo Agroindústria (MARTINS, 2006). Maria Conceição D’Incao (1990) denomina este momento de "revolução burguesa", pois seria questionável esta reforma agrária enquanto aquela que se configura numa etapa à reforma social, de fato.

Tratava-se, na vertente, do discurso possível, de eliminar o latifúndio improdutivo, de modo a assegurar a criação de um mercado consumidor

\footnotetext{
${ }^{40}$ Pode-se citar obras de infraestrutura, tais como: Companhia Siderúrgica Nacional (CSN), Companhia Vale do Rio Doce (CVRD) ou somente Vale, Hidrelétrica do Vale do São Francisco, e a criação do IBGE.
} 
interno no meio rural, a produção de alimentos a baixo preço para a crescente população urbana e, embora nem sempre anunciada, a liberação de mão-de-obra e a produção de matéria-prima para os setores industriais em desenvolvimento. (D’INCAO, 1990, p. 91).

Inicia-se, portanto, um momento em que a reforma agrária é apropriada em uma versão de atender ao projeto de desenvolvimentismo do país, como também naquela de ser um caminho à reforma social. Dedica-se, a partir de agora, e de forma breve, ao inquérito das ações e/ou discursos característicos de reforma agrária ensejados ao longo da história do país, para então adentrar nos contextos que fizeram com que os assentados do Cafundão fizessem a petição por tal política.

\subsection{A política brasileira de Reforma Agrária: diretrizes gerais.}

Será preciso ratificar que o recorte espaço-temporal que norteia essa pesquisa foi escolhido com base na análise do tratamento agrário-agrícola que se faz no Brasil, sua construção enquanto política de reforma agrária e as faces que ela adquire aos assentados do Cafundão. Por este motivo, conveniente tornou-se o retorno às formas de apropriação do espaço brasileiro em sua historicidade de construção. Isto por que, parte-se das apropriações de espaço a partir do processo de colonialidade. As formas anteriores categorizadas sumariamente em indígenas exercem seu esforço de influência ainda hoje, apesar de sobre elas restarem o silenciamento, a sobreposição, suas vozes não compõem a História ${ }^{41}$ que se conta. A despeito de não serem aqui também abordadas, não se pretende ratificar esta negação de memórias: reconhece-se somente o limite desta pesquisa e seu caráter restritivo de abordar as políticas agrárias enquanto maneira de contextualizar os próprios assentados do Cafundão

\footnotetext{
${ }^{41}$ Quando se utiliza a palavra história, com letra minúscula, é para designar um remembramento, algo que se quer contar, uma sistematização de informações. Já o uso com letra maiúscula não remete à ciência História. A sua adoção é realizada no sentido de se referir àquela oficial ou adotada por um grupo, em outras palavras, traduz um empacotamento de eventos e registros que se quer que perdure e vá além do espaço-tempo que o produziu. A História emerge, portanto, enquanto memória social escolhida, "que atravessa a história e a alimenta." (LE GOFF, 1924, p. 13). No caso dos grupos com memórias e existências sobrepujadas pela colonialidade, Costa e Suzuki (2012, p. 02) infere que "o país nasce mais como espaço a ser conquistado, dominado e complexizado em nome de uma unidade, do que como síntese de relações processuais que formaram sua sociedade, a heterogeneidade do seu povo". Neste sentido, a História se traduz na concretização de uma "ideologia espacial que consolida o Brasil como Estado-Nação, no decorrer dos séculos XIX e XX e no contexto de uma trajetória politicoeconômica controversa." (COSTA e SUZUKI, 2012, p. 02).
} 
no cenário brasileiro. A partir da contextualização, poder-se-ia subsidiar o entendimento acerca do que é ser assentado e do processo de luta pelo assentamento.

Destarte, não se tem pretensão historiográfica de tornar esta textualização minuciosa, contendo todos os eventos alçados à História. É evidente que momentos cruciais não serão abarcados por conta do limite instituído pelas páginas desta textualização e pelo tempo do fazer da pesquisa, que é delimitado em vinte quatro meses.

$\mathrm{Na}$ esteira deste processo, segue-se com a compreensão de que atores importantes na História brasileira ora sofreram menção restritiva a uma ação, ora foram e serão praticamente vulgarizados, pois servem à conversação com o eixo teórico adotado enquanto baila do diálogo. Por exemplo, Luciano Aronne de Abreu (1996) investiga a vida política de Getúlio Vargas, e ressalta que a exacerbação e a mitificação de sua imagem após a chegada à Presidência da República dificultaram, inclusive, a achar dados acerca desta vida política anterior ao ser Presidente. Neste sentido, interessa-se neste diálogo pelas ações, tomadas de atitude e posicionamentos no que se referem à gestão priorizando o aspecto agrário-agrícola, sem, contudo, contribuir para ratificar o mito de tais nomes que foram e serão apontados. Evidencia-se, portanto, alguns cenários a fim de compor o eixo da discussão. Mas, sabe-se que eles não se restringem àquilo que se dá aqui destaque, e sim trata-se de uma maneira de realizar e tornar possível o esforço da pesquisação.

Porquanto, dá-se prosseguimento ao contexto em que a reforma agrária adquire sentido amplo de atender aos anseios chamados de desenvolvimentistas que, amplamente, se relacionam à potencialidade de servir ao crescimento econômico do país pelo aumento da produtividade e do consumo. Como também, é concebida enquanto etapa à reforma social e por isto canaliza as inquietações que se conformam enquanto pressões que substanciam os chamados movimentos sociais - que são organizações ora partidarizadas, mas sempre politizadas que possuem uma bandeira específica de defesa, mas que de forma geral visam a uma reestruturação do espaço ao benefício da sociedade como um todo.

Aliás, acerca do desenvolvimentismo, Costa e Steinke (2014, p. 3) explanam que, a partir de 1950, o Estado se impõe à nação através de uma "ideologia de um novo programa político-econômico para o Brasil moderno, com conteúdo industrial-urbano definido”, a qual denomina de "ideologia espacial do Estado nacional". As condições para este novo projeto político advém, segundo os autores, das transformações processuais em torno da "questão nacional vinculada ao poder do Estado", que se expressam através da proclamação da 
República brasileira em 1889 e das relações de trabalho e produção que passaria do escravismo ao assalariado. Além disso, haveria também o quadro social classista e desigual que, juntos, criaram “condições efetivas para o progresso assentado na industrialização, na urbanização e na europeização" (COSTA e STEINKE, 2014, p. 5).

De forma estratégica, a construção do Brasil moderno estar-se-ia também assentado na conciliação do urbano e do rural, o que angariou a versão populista e nacionalista a Getúlio Vargas no governo de 1930. Para Costa e Steinke (2014, p. 6), Getúlio deu fôlego novo à ideia de modernização quando defendeu a Marcha para o Oeste e criou o IBGE enquanto voz estatal na divulgação de indicadores do próprio Estado. "O velho ideal da interiorização da Capital - retomado - coincidiu com o movimento expansionista geopolítico getulista, que articulava segurança nacional e modernização das estruturas econômicas, sociais e administrativas". Desta forma,

O período 1930-1964 retrata importante capítulo da formação do capitalismo nacional e é marcado por debates (e por ações) vinculados à vocação agrária e/ou industrial do Brasil. O esforço era o de diluir os enclaves de poder político correspondentes aos enclaves de poder econômico, enquanto remanescentes da história territorial colonial, com a tese de que o desenvolvimento do país era possível via industrialização substitutiva de importações. [...] Enalteceu-se a ideologia de que o país da economia dependente-imperfeita tinha condições de se libertar políticoeconomicamente, com centros nacionais de decisões e poder para desmantelar as amarras do latifundismo e do imperialismo. Para tornar-se autônoma, nacional, a economia brasileira deveria ser impulsionada por um regime político apoiado numa aliança de classes urbanas e rurais (COSTA e STEINKE, 2014, p. 6).

Além disso, estes autores enfatizam os ganhos quantitativos, e até qualitativos, do "Brasil desenvolvimentista, com Estado demiurgo da sociedade" (COSTA e STEIKE, 2014, p. 8), quais sejam: o ganho econômico e social a partir da ação combinada entre poder público e capital privado nacional e estrangeiro, o enaltecimento do sindicalismo e da escolarização difundida à formação de cidadãos, a busca pela liberdade de imprensa e o debate sobre questões da vida social.

A mobilização popular nas cidades e no campo seriam uma consequência da modernização da economia. A população se exasperou ante o fato que as 
promessas feitas pelo Estado, aquelas de uma política em favor dos desfavorecidos, não foram executadas. Pouco a pouco, estas populações entenderam que a modernização os excluía dos benefícios do crescimento econômico (VLACH, 1997 apud COSTA e STEINKE, 2014, p. 8).

Aliás, o contexto do desenvolvimentismo ganhou uma "alavanca de retomada mais firme do crescimento econômico" com o governo de Juscelino Kubitscheck, em 1956, e seu slogan de cinquenta anos em cinco. Apoiou-se na inversão de "capital público em obras de natureza infraestrutural, aliado a atividades e investimentos privados de monta, uma vez que uma de suas grandes preocupações era atrair capitais estrangeiros, que estavam se retraindo e mais, justificar suas ações por meio do apoio popular" (COSTA e STEINKE, 2014, p. 7). Em seu Plano de $\operatorname{Metas}^{42}$, para o governo de 1956 a 1961, consta que os setores de energia e de transporte receberam juntos cerca de $72,6 \%$ de todo o investimento nacional, o que Costa e Steinke (2014) evidenciam enquanto tentativa de construir uma indústria de base que alavancaria atividades produtivas diversas. E o setor de alimentação obteve 3,2\% de todo o investimento nacional, subdividido nas tarefas ligadas ao aumento da produção de grãos, tal como o trigo, e a incorporação de tecnologias agrícolas, através do crédito à aquisição de tratores, o aumento dos frigoríficos, matadouros, armazéns e silos, bem como a difusão do uso de fertilizantes que aumentou neste período $250 \%$.

As palavras de Juscelino Kubitscheck são reveladoras de sua estratégia desenvolvimentista. "Fixei o argumento de Fernão Dias, ao deixar Taubaté: "um país se conquista pela posse da terra!"; e mais, pensava-se nessa conquista de forma específica, pela "posse da terra e a transformação de bens geográficos em bens econômicos". A arrancada foi dada em prol de uma maciça equipagem do território [...] mas a expensas dos desequilíbrios regionais e disparidades sociais agravadas, via concentração de renda em estratos sociais e por regiões. Alarmou o contexto o fato de que o Plano de Metas apresentou um cunho notoriamente político, em detrimento do essencialmente técnico, ou seja, foi elemento estratégico de sustentação do poder de um Governo, uma "âncora", então, ao nacionaldesenvolvimentismo (COSTA e STEINKE, 2014, p. 15).

Não obstante, Mary Del Priore e Renato Venâncio (2006b, p. 198) destacam que "para os defensores da industrialização acelerada era fundamental a implementação de medidas rápidas de modernização da estrutura agrária existente. A reforma agrária consistia numa

${ }^{42}$ (COSTA e STEINKE, 2014, p. 13). 
delas. Mais ainda. Havia apoio internacional para este tipo de medida". Este apoio internacional, neste momento advindo principalmente dos Estados Unidos da América (EUA), é atacado naquele Manifesto de Prestes (1935) que acusa o país de se vender ao imperialismo. Mas, não seria somente este aspecto econômico o responsável por tal interesse estrangeiro no país. Havia a necessidade de se combater, conforme já dialogado, o avanço dos ideais comunistas e a diminuição da pressão social que se fazia presente , no litoral, efervescente nas principais capitais, sobretudo, Rio de Janeiro e São Paulo (COSTA e STEINKE, 2014).

O termo reforma agrária passa, então, a atender a interesses ambíguos de uma suposta atuação em prol da diminuição da desigualdade social e da ampliação ao acesso a terra, como também o contrário, o incentivo à agroexportação, através de créditos agrícolas e inserção fiscal. Por este motivo que Ângela Almeida (2000) afirma que a historicidade da desigualdade agrária somada à priorização do Estado pela grande propriedade e à concessão de incentivos para a agroexportação irão caracterizar o Brasil enquanto potencial à entrada na modernidade através da agricultura mecanizada.

E isto se intensifica a partir da apropriação, por diversos setores, do termo e de ações efetivas no tocante à reforma agrária que passa a significar e a designar ambíguas questões. A reforma agrária guarda em si mesma ações que se referem à terra, de forma a privilegiar o seu sentido agrícola em detrimento da reestruturação agrária, que se faz neste momento de forma tímida, conforme pode ser demonstrado por Carlos Guanziroli (2000) que se utiliza dos dados oficiais do INCRA em publicação expedida pelo Ministério do Desenvolvimento Agrário MDA. Este autor revela que, entre os anos de 1927 e 1963, ou seja, no intervalo de 36 anos há somente dois assentamentos criados no Brasil, que significa menos de 11.000 famílias assentadas dando uma média anual de 299 famílias. Já no intervalo de 20 anos seguintes, entre 1964-1984, conforme pode ser verificado na tabela a seguir, este número aumenta para 43 assentamentos criados, com quase 66.000 famílias assentadas em uma média anual de 3.299 famílias. Este número aumenta ainda mais no processo de redemocratização do país nas vésperas da Constituição de 1988, com um salto de 43 para 506 assentamentos criados, passa por uma diminuição significativa conjuntamente à crise financeira que assola o país, e começa a ascender novamente pós-instituição do Plano Real em 1994.

Tabela 1: Evolução dos assentamentos de reforma agrária no Brasil, originados por ações do Governo Federal (INCRA - MEPF).

$\begin{array}{llll}\text { Número de } & \text { Número de } & \text { Número médio } & \text { Área }\end{array}$




\begin{tabular}{|ccccc|}
\hline Período & $\begin{array}{c}\text { assentamentos } \\
\text { criados }\end{array}$ & $\begin{array}{c}\text { famílias } \\
\text { assentadas }\end{array}$ & $\begin{array}{c}\text { por ano de } \\
\text { famílias } \\
\text { assentadas }\end{array}$ & $\begin{array}{c}\text { desapropriada ou } \\
\text { adquirida (ha). }\end{array}$ \\
\hline $\mathbf{1 9 2 7}-\mathbf{1 9 6 3}$ & 2 & 10.776 & 299 & - \\
\hline $\mathbf{1 9 6 4}-\mathbf{1 9 8 4}$ & 43 & 65.993 & 3.299 & - \\
\hline $\mathbf{1 9 8 5}-\mathbf{1 9 8 9}$ & 506 & 83.732 & 20.933 & - \\
\hline $\mathbf{1 9 9 0}-\mathbf{1 9 9 2}$ & 229 & 45.137 & 22.568 & - \\
\hline $\mathbf{1 9 9 3}-\mathbf{1 9 9 4}$ & 111 & 36.481 & 18.240 & 1.461 .992 \\
\hline $\mathbf{1 9 9 5}-\mathbf{1 9 9 6}$ & 745 & 104.956 & 52.478 & 3.286 .428 \\
\hline $\mathbf{1 9 9 7}$ & 610 & 82.000 & 82.000 & 1.820 .077 \\
\hline Total até $\mathbf{1 9 9 7}$ & 2246 & 429.075 & 199.817 & 6.568 .497 \\
\hline
\end{tabular}

Tabela elaborado pela autora, baseado em Guanziroli (2000) e INCRA (Diretoria de assentamentos, MEPF).

Percebe-se através dos dados desta tabela que somente a partir de 1993 é expressa a adoção de área desapropriada ou adquirida pela União enquanto método de assentar famílias. Antes disso, o formato de reconhecimento de terras já ocupadas era o mais adotado, como se verá, isto se deu enquanto forma de não se atritar com o latifúndio. A este respeito, Del Priore e Venâncio (2006b) destacam que, no início do século XX, isto se expressa através da dedicação à ocupação de terras em todo o país, expressa pela relação disponibilidade de terras versus o contingente populacional que representa uma pressão da luta pela terra de forma mais amenizada.

Lembre-se, leitor, que no início do século XX a população brasileira ainda era inferior a vinte milhões [...]. Havia imensidões não ocupadas. Isso diminuía a pressão da luta pela terra. Ao se lerem as Mensagens do Congresso dos presidentes da República Velha, percebe-se a ausência a qualquer menção à reforma agrária. A todo instante menciona-se, porém, o vasto território a ser ocupado e colonizado. O problema não era a carência de terras, e sim a falta de braços para o trabalho na lavoura. (DEL PRIORE e VENÂNCIO, 2006b, p. 196-197).

Guanziroli (2000) explica que estes números traduzem também a dedicação do país a esta política de reforma agrária de forma dependente de seu contexto político-econômico, percebido que em momentos de crise há uma interrupção ou diminuição drástica de tal política à consecução de outras prioridades. Nesta linha de raciocínio, Pedro Henrique 
Carinhato (2008) destaca que em momentos que se faz a crítica à intervenção estatal na economia, sobretudo a partir da década de 1980 e 1990, houve na mesma medida a subestimação das políticas sociais, conforme se verificará com Guanziroli (2000) que defende ideais da liberalização da economia e da diminuição do Estado enquanto respaldo à agricultura familiar em revista do Ministério do Desenvolvimento Agrário. De forma estendida, a maneira como ela passa a ser concebida e executada tornam-se dependentes também dos agentes executores e dos partidos que expressam as filiações (e bandeiras) políticas de tais agentes. No caso das terras do Cafundão, por exemplo, a efetivação da política de reforma agrária confundiu-se com conflitos partidários e competências institucionais, que prolongaram a resolução do conflito por considerá-lo somente um impasse.

Neste sentido, Carlos Guanziroli (2000) diz ser necessário relacionar as tentativas de realização de reformas agrárias às tendências socioeconômicas, inclusive no que se refere aos contextos mundiais. Ele menciona que a influência do desenvolvimentismo e as chamadas reformas de base fizeram com que as políticas sociais fossem sucateadas, a despeito do aumento da mobilização social. A inibição de políticas sociais se dá num viés de gestão técnica e econômica de elencar prioridades, em que o beneficiário, agora assistido por um Estado que o representa, nem sempre se traduz em preferência. Nesta linha de raciocínio, a desigualdade social, ao invés de algo estrutural, seria posta enquanto inerente à condição de ser subdesenvolvido. Acerca das políticas de reforma agrária, Rafael dos Santos (2011) salienta que

[...] quando adotadas pelo Estado brasileiro, funcionam de acordo com as concepções de cada governo no enfrentamento da questão agrária, e principalmente com a intensidade da luta pela terra. Enfrentar essa questão não implica somente em propor políticas de desenvolvimento para os territórios rurais, implica em enfrentar o latifúndio e o agronegócio, em todas as suas dimensões, como os maiores responsáveis pela concentração da propriedade da terra e precarização do trabalho e vida no campo. Implica em garantir que a agricultura camponesa tenha seu espaço de produção e sustento, com condições para tal, tenha seu território valorizado e protegido, o que refletirá na redução dos conflitos. Enfrentar a questão agrária significa propor e concretizar novas formas de uso e ocupação da terra e do território. (SANTOS, 2011, p. 65)

À guisa de exemplificação, Rafael dos Santos (2011) destaca a expectativa gerada com a posse de Luiz Inácio Lula da Silva, em 2003, no que concerne aos avanços significativos em 
favor das populações rurais e outros grupos excluídos socialmente, tais como os quilombolas. O Segundo Plano Nacional de Reforma Agrária (II PNRA) "renovou as esperanças entre os movimentos de luta pela terra e os apoiadores da reforma agrária”, através da previsão de democratizar o acesso a terra, do fortalecimento da agricultura familiar, além da estruturação agrário-agrícola visando ao desenvolvimento territorial e regional, com base na sustentabilidade. Este autor ressalta que o primeiro mandato do governo Lula, em 2003, alavancou o número de ocupações de terra, enquanto forma de pressão social e promoção de diálogo com o governo, "de modo parecido com o ocorrido em 1985, no contexto de redemocratização do país e elaboração do I PNRA” (SANTOS, 2011, p. 65).

Segundo a tabela a seguir construída com base nos dados do Sistema de Informações de Projetos de Reforma Agrária - SIPRA de 1994 a 2002, o período corresponde ao primeiro mandato de FHC, entre 1995-1998, houve uma ascensão do número de projetos de assentamentos criados, bem como um aumento da área desapropriada e concedida.

Tabela 2: Números de projetos de assentamentos criados entre o período de 1994 a 2002, conforme SIPRA.

\begin{tabular}{|c|c|c|}
\hline ANO & $\begin{array}{c}\text { NÚMERO DE PROJETOS DE } \\
\text { ASSENTAMENTOS CRIADOS }\end{array}$ & $\begin{array}{c}\text { ÁREA DESAPROPRIADA } \\
\text { OU ADQUIRIDA (ha) }\end{array}$ \\
\hline Até 1994 & 934 & 16.457 .479 \\
\hline 1995 & 392 & 2.629 .428 \\
\hline 1996 & 465 & 2.570 .941 \\
\hline 1997 & 714 & 4.193 .169 \\
\hline 1998 & 756 & 3.002 .660 \\
\hline 1999 & 670 & 2.299 .659 \\
\hline 2000 & 423 & 2.154 .305 \\
\hline 2001 & 475 & 1.846 .826 \\
\hline 2002 & 385 & 2.451 .785 \\
\hline TOTAL ATÉ 2002 & 5.214 & 37.606 .252 \\
\hline
\end{tabular}

Tabela elaborada pela autora, segundo SIPRA (1994, 1995, 1996, 1997, 1998, 1999, 2000, 2001, 2002).

Por sua vez, no segundo mandato de FHC, há o movimento oposto de diminuição gradativa de assentamentos criados. Além disso, Fernandes (2008) culpabiliza o processo de criminalização dos movimentos, que foi algo que incendiou a luta pela terra com a posse de Lula em 2003. 
A primeira gestão do governo Lula começou com uma grande esperança pela realização da reforma agrária. Os movimentos camponeses realizaram o maior número de ocupações de terras e de família da história da luta pela terra no Brasil. Ao contrário da segunda gestão do governo FHC, que criminalizou as ocupações, o governo Lula sempre dialogou com os movimentos camponeses (FERNANDES, 2008, p.8).

Segundo Rafael dos Santos (2011), a reforma agrária avançou durante o governo Lula, no sentido da promoção e ampliação de políticas, tais como a Lei de Assistência Técnica e Extensão Rural (ATER) em 2010, as ampliações do Programa Nacional de Educação na Reforma Agrária (PRONERA), do acesso ao crédito, da seguridade alimentar, da infraestrutura e moradia. Além disso, diversificou as tipologias de assentamentos, tais como Projeto de Assentamento Agro-florestal (PAF) e o Projeto de Desenvolvimento Sustentável (PDS), com peso ao reconhecimento das populações tradicionais, tais como os quilombolas, e a situação de posseiros. Contudo, o apoio ao agronegócio também foi expressivo.

Este avançou nas terras agricultáveis do país deslocando a fronteira agrícola e solidificando um modelo de desenvolvimento baseado na monocultura, na produção de comoditties, nas grandes extensões de terra, nas práticas predatórias dos recursos naturais, na reprodução ampliada do capital no campo. O agronegócio se torna cada vez mais atividade de grandes corporações e empresas nacionais e estrangeiras, de diversos setores, atraídas por condições favoráveis propiciadas pelo governo através de elevados subsídios agrícolas (SANTOS, 2011, p. 66).

A este respeito, Frei Betto (2005) descreve a ambiguidade em torno da dependência da pequena e média produção à alimentação do brasileiro, ao passo que a agropecuária absorve os maiores incentivos e créditos agrícolas. Esta ambiguidade fora reforçada no governo Lula, a despeito dos avanços significativos, principalmente no que concerne à abertura ao dialogo com os movimentos sociais.

O grosso da produção agropecuária do país depende das pequenas e médias propriedades. No entanto, o maior volume de crédito ainda é absorvido pelas grandes propriedades. Os produtos de exportação são isentos de ICMS na produção, na comercialização e na importação de insumos agrícolas. Eis a prova de como o Estado brasileiro e, a reboque, o governo, ainda são reféns do grande capital (BETTO, 2005, s.n.t.). 
De forma geral, fala-se de um processo ambíguo que diz respeito à intensificação dos incentivos e créditos para a agroexportação, ao mesmo tempo em que a luta pela terra passa a se enveredar pelo reconhecimento de posseiros e de populações tradicionais. Isto influenciou, segundo Santos (2011, p. 75), no formato da reforma agrária que passa a ser adotado de forma distanciada do enfrentamento "do latifúndio e do agronegócio com as desapropriações". Ou seja, é um formato que não produz uma reestruturação agrária, de fato, ao passo que propicia aos agricultores familiares acesso às políticas de reforma agrária e à assistência técnica.

Segundo o Banco de Dados da Luta pela Terra - DATALUTA (NERA, 2004; 2005; 2006; 2007; 2008; 2009; 2010; 2011; 2012), a virada do primeiro para o segundo mandato do governo Lula atingiu patamares significativos de criação de assentamentos de reforma agrária, com 853 projetos criados no ano de 2005.

Tabela 3: Número de projetos de assentamentos criados entre o período de 2004 a 2012, de acordo com DATALUTA.

\begin{tabular}{|c|c|c|}
\hline ANO & $\begin{array}{c}\text { NÚMERO DE PROJETOS DE } \\
\text { ASSENTAMENTOS CRIADOS }\end{array}$ & $\begin{array}{c}\text { ÁREA DESAPROPRIADA } \\
\text { OU ADQUIRIDA (ha) }\end{array}$ \\
\hline $\mathbf{1 9 4 2}$ a 2004 & 6.241 & 34.823 .679 \\
\hline 2005 & 853 & 13.832 .300 \\
\hline 2006 & 407 & 4.072 .747 \\
\hline 2007 & 147 & 885.784 \\
\hline 2008 & 322 & 4.114 .287 \\
\hline 2009 & 297 & 4.616 .065 \\
\hline 2010 & 205 & 1.823 .623 \\
\hline 2011 & 109 & 1.902 .884 \\
\hline 2012 & 117 & 317.597 \\
\hline
\end{tabular}

Tabela elaborada pela autora. Fonte: NERA - Núcleo de Estudos, Pesquisas e Projetos de Reforma Agrária - FCT/ UNESP Coordenação: FERNANDES, Bernardo Mançano. Presidente Prudente, São Paulo. Janeiro de 2006. DATALUTA - Banco de Dados da Luta pela Terra: Relatórios de NERA (2004; 2005; 2006; 2007; 2008; 2009; 2010; 2011; 2012)

Percebe-se, entretanto, uma incompatibilidade de dados no que concerne a, por exemplo, área desapropriada ou adquirida em 2002, que era de aproximadamente 37,6 milhões de hectares (ha), conforme tabela anterior, e a área registrada em 2004, que é de 34,8 milhões de hectares. Mas, esta diferença nos dados é interessante de ser analisada, pois a primeira tabela trata de dados governamentais que são anuais, que podem estar sobre- 
estimados para fins de alcance social. E a segunda, são dados oriundos de uma rede de estudos sobre reforma agrária, que considera o número de assentamentos de forma cumulativa para o ano de 2004.

Contudo, para dar prosseguimento àquilo que se tornou uma forma de apropriação do termo reforma agrária, Del Priore e Venâncio (2006b) destacam que entre 1947 e 1962 houve a apresentação de 45 projetos que dispunham sobre a reforma agrária no Congresso Nacional. Estes projetos atenderiam a diversos interesses, tais como dos populistas - que se utilizam de ações sociais à promoção de si mesmos no cenário também político -, dos comunistas - que acreditam na reforma social -, e dos imperialistas - que se utilizam de sua face técnica e econômica capaz de ampliar lucros.

Como se vê, foi somente há cinquenta anos [1950] que o debate em relação à reforma agrária se tornou a efetivamente público, mobilizando vários segmentos da população brasileira. Essa demora não significou submissão ou passividade. Afinal, cabe lembrar que os movimentos milenaristas e o banditismo foram um traço constante em nossa história rural. (DEL PRIORE e VENANCIO, 2006b, p. 196).

Durante estes momentos nos quais se enfoca o aspecto da legislação agrária, o Brasil passava por conturbados períodos que podem ser expressos através da história de alternância dos que estiveram em sua linha de frente ${ }^{43}$. Inicialmente, enquanto pertencente a Portugal, absorve suas leis agrárias e nasce sobre o pilar das capitanias hereditárias e das sesmarias. Com a instituição da Independência, permanece a figura de Imperadores portugueses, até a instauração da República. Sob a Primeira República, há a escolha de dois militares para governarem o país, que foram Deodoro da Fonseca (1889 - 1891) e Floriano Peixoto (1891 1894). Através das eleições diretas, em que Prudente de Morais (1894 - 1898) assume o poder, os partidos políticos também adentram a arena de disputa pela Presidência da República, que vai até Julio Prestes, em 1930, que não assumiu por conta do Golpe de Estado dado por Getúlio Vargas - que governara 16 anos, ou seja, até 1946 com o partido da Aliança Liberal (AL). Tais partidos que elegeram Presidentes até este momento foram: Partido Republicano Federal (PR Federal), Partido Republicano Paulista (PRP), Partido Republicano Mineiro (PRM), Partido Republicano Fluminense (PRF), Partido Republicano Conservador

\footnotetext{
43 Baseando-se na Galeria de Presidentes do sítio oficial do Palácio do Planalto, disponível em: http://www2.planalto.gov.br/acervo/galeria-de-presidentes. Acesso em 19 de novembro de 2014.
} 
(PRC), com destaque para alternâncias sucessivas entre o partido de origem mineira e aquele paulista.

No ano de 1946 há a primeira redemocratização do país através da instituição das eleições na qual Eurico Gaspar Dutra é eleito pelo Partido Social Democrático - PSD, para governar até 1951, com o mandato de cinco anos instituído pela mencionada Constituição de 1946, que também retoma o cargo de vice-presidente. Na eleição posterior, há o relançamento de Getúlio Vargas, pelo seu recém-fundado Partido Trabalhista Brasileiro (PTB), por conta daquilo já destacado como populismo, que reside em sua imagem com aceitação social também por causa de suas investiduras em leis e regulamentações trabalhistas. Seu vice, Café Filho, assume o posto após Vargas suicidar-se no último ano de mandato. Entre 1955 e 1964, há a oscilação entre eleições pelo voto direto e escolhas indiretas, dentre o qual destaca-se Juscelino Kubitschek (1956 - 1961) que, dentre outras ações, muda a capital do Brasil para o então Distrito Federal, na fronteira de Goiás e Minas Gerais. Este governo também é marcado pelas ações no que concerne à infraestrutura brasileira e à formação de um novo discurso nacional baseado no progresso e na modernidade. Juscelino teve como sucessor Janio Quadros, que renuncia, é substituído por interinos, até a eleição de João Goulart em 1961, com mandato interrompido em 1964 com o golpe militar que perdurou até 1985, configurando-se na segunda ditadura do país.

Este momento do país inaugura uma fase apontada por Maria Celina D’Araújo (1996) como bipartidarismo, que se deu por meio do Ato Institucional $n^{\circ} 2$, através do qual o governo ditatorial dissolveu os partidos existentes no país e impôs dois partidos: a Aliança Renovadora Nacional (ARENA), que abarcou aqueles partidos com inclinações conservadoras, com destaque para União Democrática Nacional (UDN). E o segundo partido que é o Movimento Democrático Brasileiro (MDB), dentro do qual estava o PTB e outros de inclinação de centroesquerda. A partir da reconstrução histórica do Partido Trabalhista Brasileiro (PTB), pelo qual elegeu-se Getúlio Vargas (1951 - 1954) - que é também fundador - e João Goulart (1961 1964), esta autora realiza uma análise acerca da estrutura interna de poder deste partido, de suas estratégias políticas às quais ela chama de ambíguas, e da instabilidade interna e externa que acaba influenciando o regime dos seus eleitos, com destaque para o segundo governo de Getúlio Vargas. Maria Celina D’Araújo (1996, p. 167) destaca que o PTB, à exemplo também do mencionado PCB (Partido Comunista do Brasil), configura-se num caso bem-sucedido de tradição partidária no Brasil. Esta afirmação é oriunda das tentativas de legitimar este partido 
enquanto herdeiro e comprometido com o que chama de "legado getulista" que reside no compromisso com as agendas políticas de cunho trabalhista.

Nas vésperas do bipartidarismo, a regulamentação das leis trabalhistas é estendida ao campo através do Estatuto do Trabalhador Rural - ETR, em 1963, ainda no governo de João Goulart (1961 - 1964). Este Estatuto (ETR) diz respeito à Lei no 4.214, de 02 de março de $1963^{44}$, mas que foi revogada dez anos após sua implementação, através da Lei $n^{\circ} 5.889$ de 08 de junho de 1973. Segundo Vera Lucia Ferrante (1976), o ETR configurou-se numa expressão da inserção tardia de leis trabalhistas no campo, já que estes trabalhadores não foram abarcados pelas regulamentações anteriores expresso na CLT.

Vera Lucia Ferrante (1976) acusa que este atraso se deu pela dispersão espacial que significa também a latência da pressão e organização social, às quais os trabalhadores estão submetidos. Estas tornaram a reivindicação por esta legalização no campo um pouco mais tardia, se comparada aos centros urbanos. Percebe-se que esta inferência realizada pela autora se faz com base na influência ideológica - comunista, a favor do direito a terra e do trabalhador, em defesa do operário e do camponês - que penetrou mais rapidamente centros urbanos enquanto local também da comunicação, e foi se respaldando no campo de forma um pouco mais lenta, como já comentado, através da fuga daqueles que fugiam da perseguição aos comunistas na cidade. E por se tratar de uma expressão do espaço com uma estrutura desigual com velhas hierarquias nas relações, que faz com que o trabalhador se submeta a condições a fim mesmo de garantir o estar-vivo e a sobrevivência de sua família, através da exploração de seu trabalho "transformada em fatalidade" (FERRANTE, 1976, p. 190).

Contudo, Vera Lucia Ferrante (1976, p. 191) diz que este Estatuto foi muito mais uma medida populista do que a sistematização de diretrizes que seriam, de fato, aplicadas. Menciona que o FUNRURAL, que é o Fundo de Assistência e Previdência do Trabalhador Rural, criado conjuntamente ao ETR, "não passou de uma carta de intenção, sem qualquer aplicação prática" que demonstra que tais medidas "foram sempre encaradas muito mais com sentimentalismo do que com disposição para medidas concretas”. E este cenário, segundo ela, perdura até a criação do Programa de Assistência ao Trabalhador Rural - Pro-Rural, regulamentado através do Decreto $\mathrm{n}^{\circ} 69.919$ de 1972, que reconhece a aposentadoria por velhice, aposentadoria por invalidez, pensão, auxílio-funeral, serviço de saúde, serviço social.

\footnotetext{
${ }^{44}$ Disponível em: http://www.planalto.gov.br/ccivil 03/leis/1950-1969/L4214.htm. Acesso em: 20 de novembro de 2014 .
} 
No ano seguinte a criação do ETR, a política fundiária é sistematizada através do Estatuto da Terra, que é a Lei 4.504 de 30 de novembro de 1964. Este Estatuto, segundo Gervásio Rezende (2005, p.22), pauta-se em dois princípios que até este momento da construção do espaço brasileiro se mostraram inéditos. O primeiro deles reside na regulamentação do mercado de aluguel da terra, que dispõe sobre aquelas formas de apropriação baseadas na parceria ou no arrendamento, que se traduz grandemente numa maneira de respaldar o proprietário da terra. E o segundo princípio "institui a resolução do problema fundiário através da redistribuição da terra, via desapropriação das propriedades improdutivas e sua distribuição na forma de pequenos lotes, dentro dos assentamentos de reforma agrária". Este segundo princípio possui a justificativa de fazer valer o que se entende como função social da terra, instituída a partir da Constituição dos Estados Unidos do Brasil ${ }^{45}$ de 1946, na qual, em seu artigo 147, reconhece o uso da propriedade ao bem-estar social, e a redistribuição de propriedades de forma equânime a todos. E os artigos subsequentes fornecem vias de desapropriação, pagamento pela terra desapropriada, pagamento de Imposto Territorial Rural, e demais encargos.

Porquanto, o Estatuto da Terra é subdividido em quatro títulos: Disposições Preliminares; Reforma Agrária; Política de Desenvolvimento Rural e Disposições Gerais e Transitórias. Em seu Artigo $1^{\circ}$, há dois parágrafos que elucidam sobre o que se entende por Reforma Agrária e por Política Agrícola, que serviria de arcabouço ao dito Desenvolvimento Rural.

\begin{abstract}
Art. $1^{\circ}$ Esta Lei regula os direitos e obrigações concernentes aos bens imóveis rurais, para os fins de execução da Reforma Agrária e promoção da Política Agrícola.

$\S 1^{\circ}$ Considera-se Reforma Agrária o conjunto de medidas que visem a promover melhor distribuição da terra, mediante modificações no regime de sua posse e uso, a fim de atender aos princípios de justiça social e ao aumento de produtividade.

$\S 2^{\circ}$ Entende-se por Política Agrícola o conjunto de providências de amparo à propriedade da terra, que se destinem a orientar, no interesse da economia rural, as atividades agropecuárias, seja no sentido de garantir-lhes o pleno emprego, seja no de harmonizá-las com o processo de industrialização do país. (BRASIL, 1964)
\end{abstract}

\footnotetext{
${ }^{45}$ Disponível em: http://www.planalto.gov.br/ccivil_03/constituicao/Constituicao46.htm. Acesso em: 19 de novembro de 2014.
} 
Por Reforma Agrária, enuncia-se os princípios de justiça social através da distribuição de terras, e atrela este pacote de medidas ao aumento da produtividade, o que demonstra filiação ideológica com o que já se construiu anteriormente. E por Política Agrícola, o Estatuto de Terras respalda o direito à propriedade, ratifica que a economia rural deveria acompanhar o processo de industrialização do país, através do apoio às atividades agropecuárias. Amplamente, percebe-se que ele dispõe sobre a garantia do acesso a terra através da resolução do problema fundiário, por meio da reforma agrária. Como também, dispõe sobre o que chama de desenvolvimento rural que reside no incentivo ao setor agrícola brasileiro. Desta forma, esta nova Lei de 1964 disporia sobre o aspecto agrário-agrícola, na medida em que visa ao desenvolvimento industrial do campo a partir de uma reestruturação agrária. Esta Lei complementaria o projeto brasileiro em curso de promoção de crescimento econômico, a partir de obras de infraestrutura enérgica e de transporte ao desenvolvimento industrial e do campo, além da abertura e incentivo ao que se chama de mecanização agrícola (COSTA e STEINKE, 2014).

Porém, o que se percebe é justamente a construção de um aparato legal que justifique a priorização da questão agrícola em detrimento da questão agrária, conforme enunciado no Capítulo 01. E mais, Maria Conceição D’Incao (1990, p. 92) ressalta o caráter ambíguo deste Estatuto na medida em que ele vincula "a proposta de reforma agrária e o projeto desenvolvimentista”. Isto por que,

[...] à possibilidade de desapropriação de terras por interesse social, condição legal para a realização de uma política de reforma agrária, este estatuto contrapõe o conceito de empresa rural, não passível de desapropriação. Mais do que isto, incentiva o desenvolvimento da agricultura empresarial, dimensionando o imposto territorial rural na razão direta da produtividade da terra e, indiretamente, deslocando a questão da reforma agrária para 'áreas prioritárias' e/ou programas de colonização. Tratava-se sem dúvida de promover a distribuição de terras para ou nas fímbrias do desenvolvimento econômico da agricultura (D’INCAO, 1990, p. 92).

Além disso, este Estatuto funciona enquanto mitigador da pressão social, que ganha relevo mediante o avanço da ideologia comunista, da Revolução Cubana (1959) e da notícia da implantação de reformas agrárias em países como a Bolívia e o México. Ou seja, propor a realização de reforma agrária na Lei de 1964 seria também garantir um horizonte de reformas 
que, efetivamente, não foram realizadas. E como horizonte, há a tentativa de que este ofusque a luta pela terra, por que ela estar-se-ia sempre às vésperas de ser empreendida.

Nesta linha de pensamento, revela-se a criação da Confederação Nacional dos Trabalhadores da Agricultura - CONTAG, em 1963, e dos programas voltados à colonização, conforme menciona D'Incao (1990). A CONTAG emerge num contexto de institucionalizar os sindicados, voltados aos trabalhadores da agricultura, que se espalhavam pelo território brasileiro. Para Maria da Conceição D’Incao (1990, p. 95), esta Confederação é criada com influência do PCB e passa a ser a responsável pelo Projeto de Reforma Agrária que perdura até hoje.

Um fator importante destacado pela autora reside no fato de a CONTAG ter convergido e absorvido, de forma legalista e institucional, os anseios das lutas sindicais mediante o cenário de repressão, bem como por ela estabelecer aproximação com o Estado que seria interlocutor e executor do projeto. Isto por que, "o Estado seria o único agente capaz de implementar uma política distributiva e traçar novos rumos para o desenvolvimento econômico. É nesse contexto que o movimento sindical da época se aproxima do governo federal e busca compor alianças”. Esse papel intermediador da CONTAG perdurou até 1979, que é o ano do fim do bipartidarismo. Ou seja, corresponde à "abertura política [que] permitiria aos sindicalistas [...] traçar novas diretrizes para a organização de suas bases" (D’INCAO, 1990, p. 95), a partir da partidarização - por exemplo, que o PCB continuasse aglutinado ao MDB.

Esta aliança CONTAG e Estado, que se relaciona com sua forma legalista de atuar, tem impedido, segundo D’Incao (1990), que o Projeto de Reforma Agrária se modifique e abarque as complexidades presentes em território brasileiro, que diz respeito, por exemplo, às diversas formas de apropriação da terra traduzidos no complexo grupo de posseiros, parceiros, arrendatários, trabalhadores de tempo parcial, boias frias, assalariados permanentes, temporários, desempregados do campo, filhos dos pequenos proprietários, minifundistas, os próprios assentados de reforma agrária e os agricultores familiares consolidados" (GUANZIROLI, 2000). Conforme D'Incao (1990),

Acredita-se [...] possível sustentar a hipótese de que a própria credibilidade conquistada pela CONTAG, firmando-se como força social hegemônica no campo, durante e apesar do regime militar, é parcialmente responsável pelo tardio desenvolvimento de análises críticas ao seu projeto de reforma agrária. Entre os intelectuais que vêm se empenhando na análise da questão agrária, 
por exemplo, é possível perceber um diálogo permanente com o referido projeto, tanto na sua face aparente do discurso desenvolvimentista, como na sua face mais implícita da criação das pré-condições para a revolução socialista (D’INCAO, 1990, p. 94).

Além disso, D’Incao (1990, p. 99) aponta que a participação da CONTAG no momento crucial de transição para a democracia, na eleição de Tancredo Neves e no governo substituto do José Sarney (1985 - 1990), foi tímida e resguardada à indicação de nomes para posse em conselhos recém-criados, tais como Nelson Ribeiro para o Ministério da Reforma e do Desenvolvimento Agrário - MIRAD, e José Gomes da Silva na presidência do INCRA. Assim como, participou da elaboração de áreas prioritárias à execução do primeiro Plano Nacional da Reforma Agrária - PNRA, que foi pensado sob os princípios da desapropriação de latifúndios visando à justiça social, e acabou sendo aprovado de forma a resguardar os grandes proprietários de terra sob a justificativa de cumprimento da função social da terra e sem definição de áreas prioritárias. Neste mesmo momento, outras tomadas de atitude ocorreram no sentido de inserir, de fato, o Projeto de Reforma Agrária no seio das políticas, de forma conjunta aos planos de desenvolvimento rural. E, conforme já discutido, o que se percebe é a transformação em prioridade das políticas agrícolas em detrimento da discussão e execução dos planos de reforma agrária.

Neste sentido, Mary Del Priore e Renato Venâncio (2006a) apontam que a sindicalização rural, a despeito de existirem anteriormente de forma espalhada pelo país, adquire força após a criação da CONTAG, que contribuiu também para o reconhecimento de tais sindicados no Ministério do Trabalho, o que expressa a sua atuação pela via legalista. Este momento corresponde ao período em que o ETR estava criado e se estava em vias de concretizar o Projeto do Estatuto da Terra, em 1964.

Por mais surpreendente que pareça, foi somente no final do período populista que os sindicados rurais ganharam força. Embora, desde 1944, o Decreto-Lei $\mathrm{n}^{\circ} 7.038$ concedesse o direito a essas organizações, em 1961, ainda não havia um só sindicato rural reconhecido pelo Ministério do Trabalho. A partir desse ano, porém, tal quadro sofre uma profunda transformação. Para se ter ideia disso, basta mencionar, que, no início de 1964, existiam legalmente reconhecidos 270 sindicatos rurais e outros quinhentos demandavam a legalização" (DEL PRIORE e VENÂNCIO, 2006a, p. 204). 
Cabe aqui enfatizar uma questão interessante de ser analisada que reside no que Mary Del Priore e Renato Venâncio (2006a, p. 205) destacam como a estrutura sindical rural brasileira voltada aos princípios conservadores, a partir de 1964. Estes autores remetem à tentativa de repressão aos elementos ligados à esquerda por parte do governo militar instaurado, com Castelo Branco (1964-1967), aos cursos dados por meio de acordo com os Estados Unidos da América e da Igreja (católica brasileira). Tais cursos tinham como propósito o aumento da sindicalização rural por meio do princípio conservador, como contraponto daqueles outros sindicados que atuavam enquanto pressão social e em prol dos direitos e avanços aos trabalhadores. Esta tentativa de aliança entre Estado, influência externa e Igreja aumentou o número de filiados de um milhão de pessoas em 1971 para seis milhões de pessoas, em 1979. A este respeito cabe assinalar o que se entende por princípio conservador e a diferença existente entre Sindicato Rural e Sindicato dos Trabalhadores Rurais.

Neste momento, a Igreja e os princípios católicos subsidiam posicionamentos considerados da oligarquia direitista do país, e que também podem ser entendidos como sendo conservadores por se inclinar a aprofundar as características sobre as quais estavam se construindo o Brasil. Uma dessas expressões reside na criação, em 1960, do Movimento Tradição, Família e Propriedade (TFP), que hoje recebe o nome de Sociedade Brasileira de Defesa da Tradição, Família e Sociedade, fundada por Plínio Correia de Oliveira, que fora deputado da Constituinte de 1934. Este movimento baseia-se na Tradição, enquanto algo que leva ao progresso; na Família como geradora de Tradição e também de hierarquia social, a fim de garantir o que chamam de cultura e civilização; e na Propriedade, baseado enquanto algo pertencente à essência humana e resultado do fruto do trabalho, e também da acumulação familiar. ${ }^{46}$ Deste modo, este movimento TFP construiu propostas que deveriam ser inclusas no Projeto de Reforma Agrária que estava sendo edificado. Percebe-se, a partir delas, a continuidade da desigualdade no acesso a terra, já que há a proposta de concessão de créditos aos grandes agricultores, e a comprovação de recursos para na terra se estabelecer por parte dos pequenos, onde recurso emerge como critério ao acesso a terra. Além disso, há o desejo pela não-dirigência na agricultura e concessão de crédito à mecanização agrícola. Ao mesmo tempo em que, aos trabalhadores rurais, sob regimes contratuais, ficaria relegado à manutenção dos contratos para garantir a melhora de sua situação econômica por meio do seu

\footnotetext{
${ }^{46}$ Segundo seu sítio oficial, disponível em: http://www.tfp.org.br/tradicao-familia-e-propriedade/por-que-tfp. Acesso em: 19 de novembro de 2014.
} 
esforço para que se consiga, de forma paulatina, a constituição de patrimônios. Caberia a estes a venda do trabalho à acumulação de recursos para a conquista da posse da terra, conforme se percebe nas propostas de Dom Antônio de Castro Mayer.

Fixação, por lei, das condições muito excepcionais em que a desapropriação de imóveis rurais, mediante justa indenização, pode ser feita.

Crédito fácil para os proprietários de grandes áreas que as desejem colonizar. Crédito fácil também para financiamento na compra de glebas.

Crédito fácil para o equipamento das propriedades.

Assistência técnica aos agricultores. Fomento da agricultura, sem dirigismo. Concessão de terras devolutas aos pequenos agricultores, sempre que por este meio possam por eles serem exploradas.

Fomento de formas de contrato de trabalho que possibilitem um aproveitamento intenso da terra e ao mesmo tempo beneficiem o assalariado, permitindo-lhe uma situação econômica mais favorável e a constituição paulatina d eum patrimônio. Por exemplo: a parceria, as empreitadas.

Crédito especial para a melhoria das moradias dos colonos e medidas congêneres. (MAYER, 1960 apud DEL PRIORE e VENÂNCIO, 2006b, p. 198).

Tais propostas são paradoxais, ambíguas e contribuem para a manutenção das desigualdades sociais oriundas deste tratamento diferencial à questão agrário-agrícola e, sobretudo, ao tratamento que impõe a segregação entre grandes e pequenos produtores - e por isso, trata-se de ideais conservadores. O que motiva a distinção entre os Sindicados Rurais, que defendem empregadores e grandes proprietários de terra, baseados amplamente no princípio de progresso e propriedade; e os Sindicatos dos Trabalhadores Rurais, que lutam pelos direitos dos trabalhadores e melhores condições do trabalho.

É preciso parênteses para uma linha de atuação da Igreja - católica - que atua no apoio a lutas populares. Para D'Incao (1990, p. 103), é importante o papel da Igreja durante o governo autoritário, também como parte de sua reprodução institucional. Contudo, nota certa tentativa de reaproximação Estado-Igreja no período que corresponde ao da transição, em fins do ano de 1985. Inclusive, D'Incao (1990) destaca que a agenda de propostas de reforma agrária da Igreja e da CONTAG passam a ser bem parecidas, pois ambas não questionam setores ligados à agricultura, principalmente no que concerne à reivindicação social. Ao contrário, se detém às negociações aos moldes elitistas com o Estado.

Aliás, este posicionamento contra a ditadura é alvo de questionamento por parte de Fabrício de Oliveira e Franklin Rothman (2008), que analisam a relação Estado e 
Arquidiocese de Mariana se dando por vias mais estreitas do que aquelas percebidas nos demais cenários brasileiros. Esta relação estreita não se resumiu somente ao período de transição ao governo democrático, como também marcou toda a ditadura, com manifestações de apoio e reportagens que incitam a comemorar os anos sob a ordem ao progresso. Por este motivo também, a Teologia da Libertação manifestou-se nesta Arquidiocese de Mariana de forma mais marginal e entrincheirada ao discurso oficial da Igreja, a ponto de ser demonizada em reportagens.

Neste sentido, no Jornal O Arquidiocesano ${ }^{47}$, expedito pela Arquidiocese de Mariana, percebe-se primeiramente apoio àquilo chamado de revolução, que diz respeito ao golpe militar de 1964. Na reportagem de 1973, nº 720, de 01 de julho, página 03, há menção ao fato de no próximo ano ser comemorado os 10 anos da revolução que trouxera ordem ao país progredir. Além disso, menciona a importância desta ordem à proteção dos jovens, que se tornam alvo daquilo que deveria ser combatido, tal como bebidas, drogas, ideais que pregam o contrário do princípio cristão. Percebe-se também através desta reportagem que este dois poderes - Estado e Igreja -, a despeito de conflitantes, por vezes se revelam complementares. E, ainda, segundo Fabrício de Oliveira e Franklin Rothman (2008), "intrigante é o fato de que, enquanto muitas dioceses brasileiras atuavam apoiando movimentos populares nas décadas de 1970 e 1980, a Arquidiocese de Mariana legitimava a ditadura militar e não apoiava manifestações populares contestatórias das ordens econômicas, sociais e políticas vigentes". (OLIVEIRA e ROTHMAN, 2008, p.178).

Em outra reportagem, de 21 de maio de 1972, nº 662, página 02, há menção ao Estatuto da Terra como forma de garantir a manutenção do "interesse daqueles desbravadores e autênticos pioneiros que espontaneamente ocuparam a região e os interesses das empresas beneficiárias de estímulos físcais ou créditos oficiais para implantação de projetos agropecuários de desenvolvimento regional”. Já em 10 de julho de 1983, nº 1243, página 02, há reportagem denominada Teologia da Libertação que diz que esta linha da Igreja recebeu contaminação de ideais comunistas-socialistas, e que a Arquidiocese desconhece quais seriam os seus propósitos e teme pela disseminação de algo que não condiz com os preceitos e a moral da Igreja.

\footnotetext{
${ }^{47}$ Foram consultados os exemplares do jornal O Arquidiocesano, entre os períodos de 1972 a 1983, disponíveis na Hemeroteca Histórica da Biblioteca Pública Estadual Luiz de Bessa, situada na cidade de Belo Horizonte, MG. Nessa Hemeroteca, há um sistema de consulta das matérias de forma digital e, aquelas que despertaram interesse, foram selecionadas e copiadas em CD-R, mediante pagamento efetuado por página de jornal.
} 
Fabrício de Oliveira e Franklin Rothman (2008, p. 177) definem a Teologia da Libertação sob o princípio de "constituir-se num movimento social na medida em que não é apenas um campo de ideias ou crenças, mas uma tentativa de mobilizar atores sociais coletivos contra antagonistas para a promoção da mudança social”. Tais autores chamam a atenção para o fato de que as ideias da Teologia da Libertação somente adentram a Arquidiocese de Mariana no período posterior ao da redemocratização, na década de 1990. Assim, durante a ditadura a Igreja se manifesta contra o Estado autoritário e a Arquidiocese de Mariana contribui para o discurso pró-governo e contra o comunismo. Posteriormente, num período em que a Igreja estava tentando se reaproximar do Estado, na década de 1990, e "houve uma investidura do Vaticano no sentido de frear a atuação dos progressistas e um claro apoio a setores ligados à Renovação Carismática Católica, a Arquidiocese de Mariana destacou-se por sua atuação progressista, apoiando o MAB [Movimento dos Atingidos por Barragem] e mostrando-se engajada com os problemas sociais da população de sua jurisdição eclesiástica" (OLIVEIRA e ROTHMAN, 2008, p.178).

No cenário marcado pela aproximação da Igreja ao Estado, em escala nacional, e na Arquidiocese de Mariana se difunde ideais progressistas e de justiça social, D’Incao (1990) afirma que a atuação da Igreja como um todo será

[...] marcada por essa ambiguidade. [...] não tem força para enfrentar o confronto entre trabalhadores e empresários rurais, inevitável no que se refere à reforma agrária. Não realiza, durante o governo de transição, seu papel de mediador entre Estado e a luta pela terra, tão habilidosamente exercitado durante o período de abertura política. Por mediações outras, não é muito diferente o papel desempenhado pela CONTAG nesta etapa da luta institucional pela reforma agrária [...] Ao que tudo indica, a CONTAG já entra no novo governo pressionada pelos desafios que lhe são colocados pela emergência, durante o período de transição, de novas forças sociais no campo - o PT e o Movimento dos Sem-Terra, aglutinados em torno da CUT. (D’INCAO, 1990, p. 106).

Por conseguinte, a abertura política de 1979 e a redemocratização iniciada no governo de transição em 1985, marcam o nascimento do Partido dos Trabalhadores - PT - que disputaria as primeiras eleições pós-redemocratização. Assim como, é cenário do surgimento do MST enquanto organização política-social resultante da união entre movimentos sociais, sindicatos dos trabalhadores rurais e demais organizações, em 1984. Este momento também é aquele no qual se verifica os conflitos armados pela terra do Cafundão, em Mariana-MG, e o 
debate na Câmara Municipal marianense acerca da resolução dos conflitos e a posterior decisão da criação do assentamento de reforma agrária Cafundão registrado no Diário Oficial da União de $1995^{48}$.

Explica-se a opção por analisar as instituições MST, EMATER e INCRA no tocante à sociogênese da luta pelo Cafundão, no próximo capítulo. Isto porque, cada uma destas instituições teve um papel singular nesta história de luta pela terra. Contudo, o MST participou de forma indireta na luta pelo Cafundão, e pretende-se melhor enfocar que formas foram essas, tendo em vista outros assentamentos ligados a esta organização de forma mais estreita. Será interessante analisar de que forma o método da pressão social expresso pelo acampamento adentrou a luta pelo Cafundão, tendo sido uma sugestão dada inicialmente pelo Sindicato que representa trabalhadores na mineração e posteriormente por próprios membros do MST. Portanto, dedicar-se-á, no Capítulo 03, a uma versão da sociogênese da luta pela terra dos assentados do Cafundão.

\footnotetext{
48 BRASIL. DIÁRIO OFICIAL DA UNIÃO. Superintendência Regional de Minas Gerais. PORTARIA No-
} 05, DE 08 DE FEVEREIRO DE 1995. Seção 1, No 34, quinta-feira, 16 de fevereiro de 1995, p. 2078. 


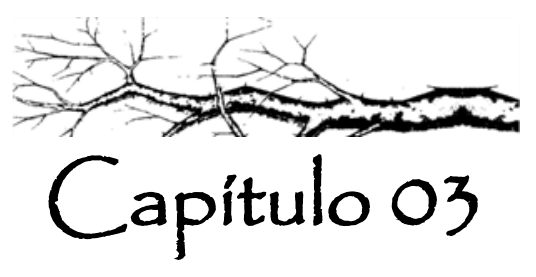

\title{
Sociogênese do assentamento:
}

\section{a reivindicação da reforma agráría dos}

\section{assentados do Cafundão (Mariana-MG).}

\begin{abstract}
"Contar é muito díficultoso. Não pelos anos que já se passaram. Mas pela astúcía que tem certas coísas passadas de fazer balancê, de se remexerem dos lugares. A lembrança da vida da gente se guarda em trechos diversos; uns com os outros acho que nem se misturam [...]. Contar seguido, alinhavado, só mesmo sendo coisas de rasa importância. Tem horas antigas que ficaram muito mais perto da gente do que outras de recente data. Toda saudade é uma espécie de velhice. Talvez, então, a melhor coísa sería contar a infâncía não como um filme em que a vída acontece no tempo, uma coisa depoís da outra, na ordem certa, sendo essa conexão que the dá sentido, princípio, meio e fim, mas como um álbum de retratos, cada um completo em sí mesmo, cada um contendo o sentido inteíro. Talvez seja esse o jeito de escrever sobre a alma em cuja memóría se encontram as coísas eternas, que permanecem..." (João Guimarães Rosa).
\end{abstract}

\subsection{Elucidações III}

[...] E as conversas sobre a história de luta pela criação do assentamento começaram a acontecer...

O senhor Nilton, risonho, apresenta-se logo. Sou o Nilton da Cooperativa, ele disse. Exprime inclusive uma expressão bem cortês parecida com algo: a quem devo a honra? Pareceu uma variação desta expressão, que não foi gravada inicialmente, o que dificulta seu 
remembramento. Antes da gravação, a título de auxílio de técnica de pesquisa empregada, era preciso apresentação, apesar de que isso já havia ocorrido em anos anteriores, por ocasião das primeiras inquietações de pesquisa desmembrada em monografia. Mas, era preciso dizer o porquê de estar ali.

Esta necessária justificativa se dava não por um motivo de tais terras serem consideradas num cerceamento, onde àqueles que chegam será preciso apresentar-se. Atrás do senhor Nilton, expresso pelo amontoado de pó, estava a Cooperativa onde produzem panelas de pedra. O estar ali poderia significar a compra de produtos, por este motivo, decidiu-se logo realizar as referidas apresentações. Perguntado se o senhor Nilton se lembra de que estivera ali antes, fez que sim com a cabeça, mas apertou os olhos e mirou os rostos: confessa em seguida que não se trata de gente estranha.

Sai lá de dentro, anteriormente abaixado em posição de cócoras colando tampas, o senhor Adão. Esse sim reconhece quem estava ali diante dele, e demorou a voltar. É explicado que a visitante agora mora em outra cidade, Brasília-DF, a mais de $1000 \mathrm{~km}$. Senhor Adão convida para conversar lá dentro do galpão.

Passa-se pelos blocos que se avolumavam do lado de fora, e que numa outra ocasião subsequente a essa primeira visita, foram removidos por questões de ordens ambientais. Entra-se na porta de ferro que possui cerca de três metros de largura. $\mathrm{O}$ galpão construído com telhas de amianto, e suas paredes desnudavam-se em tijolos, o que demonstra não haver reboco. O chão é fofo: pisava-se em pó de pedra, que era continuamente retirado e levado para nutrir suas próprias hortas.

À esquerda e à direita há tornos, cerca de cinco, distribuídos pelo galpão. Ao fundo, à direita, dois cômodos que ainda aguardam serem transformados em banheiro. Por que dois? Um para mulheres e o outro para homens. Mulheres trabalham aqui? Minha esposa [Dona Sandra] chegou a me ajudar aqui, agora ela é cozinheira de fazenda. E os tapetes de sisal, que as mulheres faziam aqui há alguns anos? [na estada anterior, inclusive, se aprendeu mais sobre os sisais vindos da Bahia e a vontade dos assentados de aprender a plantar o próprio sisal]. Ah... Foi diminuindo, até quase parar. Algumas ainda fazem bem devagar. Tinha muita gente que devia. [Lembrou-se que a Dona Sandra havia reclamado de pagamentos com cheques, e o desânimo que às vezes sentiam]. Sobre a questão dos dois banheiros, que estão há anos por serem completados, ficou subentendido que atenderia a visitantes, e eventuais usos internos, inclusive das crianças. 
Há uma verificada preocupação em receber aquele que vem ao assentamento, geralmente para comprar produtos, mas também oriundos de instituições educativas com o intuito de conhecer um assentamento de reforma agrária. Nesta visita, levou-se algumas expectativas acerca de como estaria tais assentados em relação àquilo percebido anteriormente...

Em visitas posteriores já instauradas como trabalhos de campo, percebe-se no canto direito do galpão um cômodo repleto de panelas que denuncia que o atravessador logo chega para levá-las e revendê-las. Uma semana antes, reclamam que a violência está chegando ao assentamento, na ocasião de assalto a este mesmo atravessador. Mas, o estar-entre-limites do assentamento ainda revela algum tipo de proteção em relação ao estar-fora. O assentamento tornou-se uma fronteira de vida, e um limite à proteção. Algo percebido como herdado dos tempos em que a violência era cotidiana: a ameaça de suas terras era também uma afronta ao andamento de suas vidas.

Figura 23: Travessia com o senhor Adão, que sentou-se no banco do passageiro e apontava o que se queria mostrar. Esta Travessia oscilou entre o percurso por meio de automóvel, e paragens, descidas e andanças a pé pelas terras do Cafundão. Acervo de pesquisa (2014).

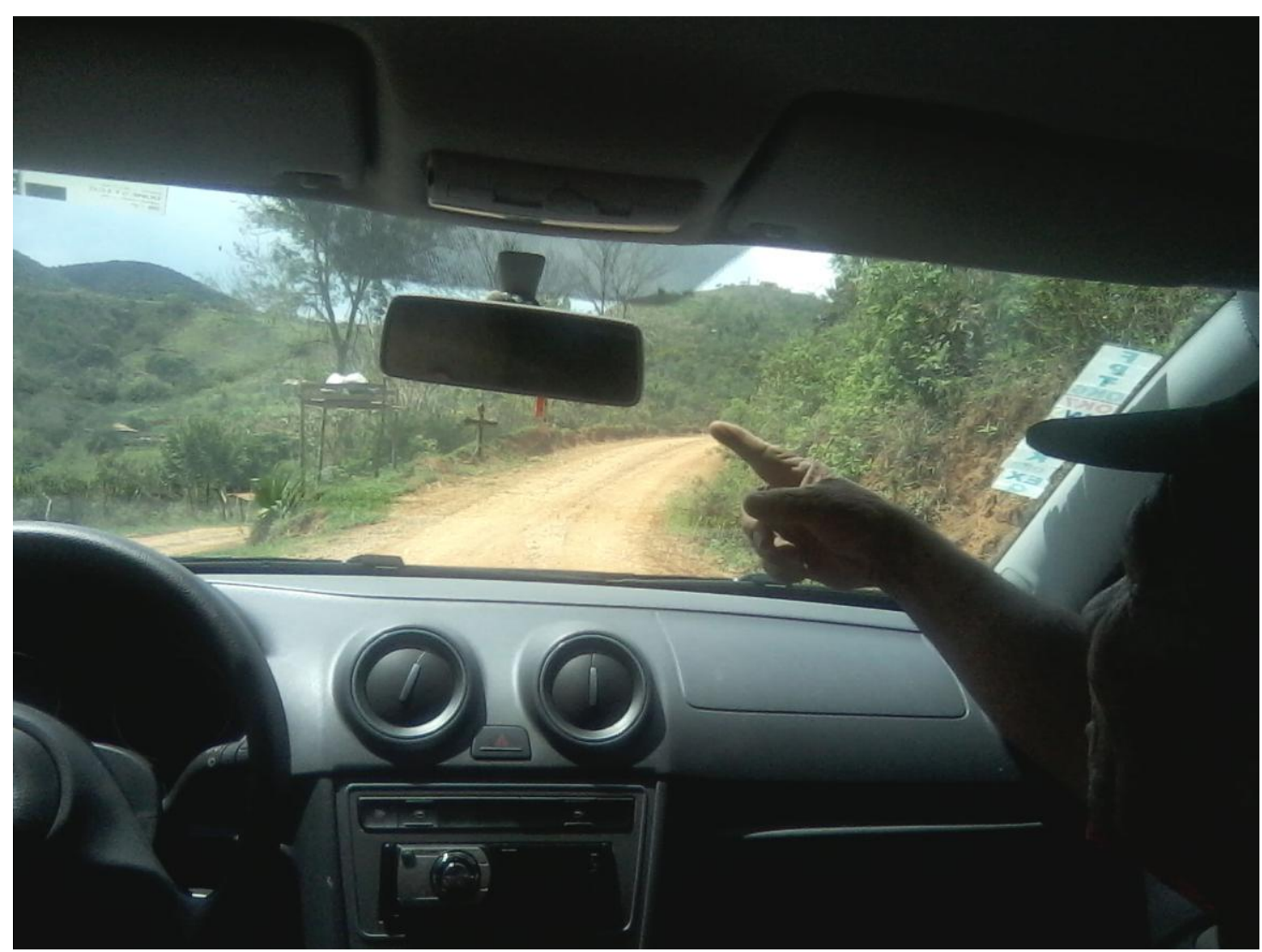


Antes mesmo de propor, o senhor Adão já se oferece para mostrar as terras do assentamento e da fazenda Cafundão, e essa diferença será entendida. A proposta da Travessia enquanto mecanismo de pesquisa se realiza numa gratuidade de quem mostra sua casa, e pede para adentrar. As casas eram as terras, e poucas vezes adentrou-se os lares. A Travessia fora feita de automóvel, com estórias, paradas para apontar lá o que houvera acontecido, gravador, GPS e sede em contar...

Os seus lares possuem a simplicidade de quem vive na e da terra. Possuem hortas, animais, e retiram de lavras cada vez mais longínquas os blocos para tornear. Seus lares possuem o formato predominante de um retângulo, com telhado inteiriço, uma porta de frente e outra de fundos, e algumas poucas janelas. Poucas possuem pintura externa e piso em cerâmica: são de cimento batido. Senhor Adão aponta onde estavam as três casas que foram queimadas na tensão pela terra. Não há nem mesmo a base da casa, somente a lembrança de onde a cerca estava disposta. Uma das casas foi de seu avô Francisco.

Figura 24: Lar da família do senhor Nilton e da dona Sandra. Acervo de pesquisa (2014).

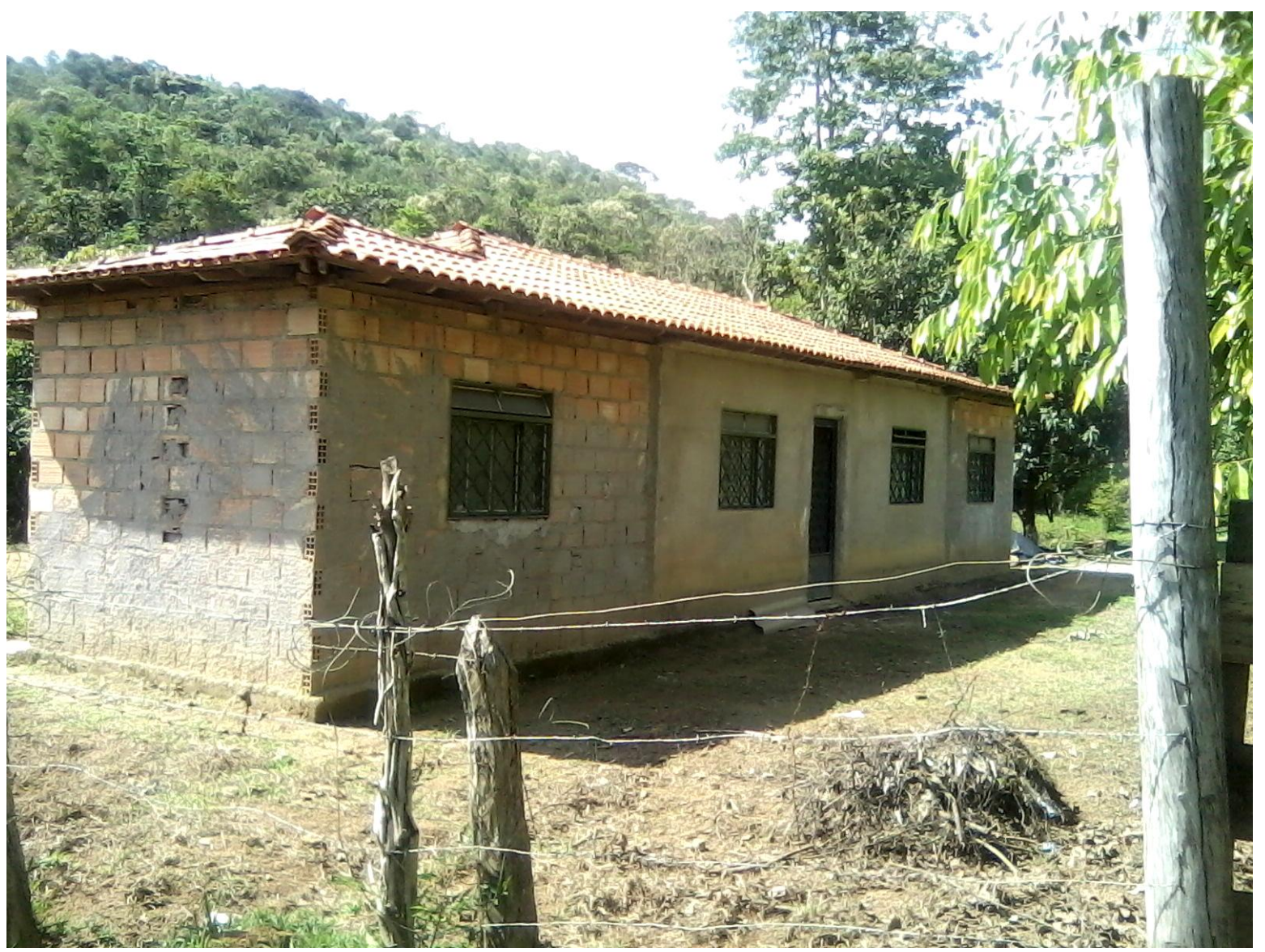


$\mathrm{Na}$ Travessia onde o carro não adentra, se percorre entre os lotes, nas áreas de passagem. Um copo d'água oferecido, uma pergunta sobre a história de luta realizada, percebia-se timidez e a esquiva escondida na afirmação de que o senhor Adão falava melhor. Mas, a violência foi vivida por cada um de uma maneira: sentiu-se a agonia da senhora que ainda hoje corre para mata quando ouve algum diferenciado barulho, ou possui uma sensação de estar sendo perseguida. Percebeu-se um sentido de uma outra família de não querer mais mencionar o que já passou e ficou pra trás. Alguns poucos só sabem da história a partir do que contam: são assentados para acessar a terra.

Figura 25: Lar da senhora que ofereceu um copo d'água por que o sol estava muito quente. Ela ainda sofre, cotidianamente, a violência psicológica pela terra do Cafundão. Acervo de pesquisa (2014).

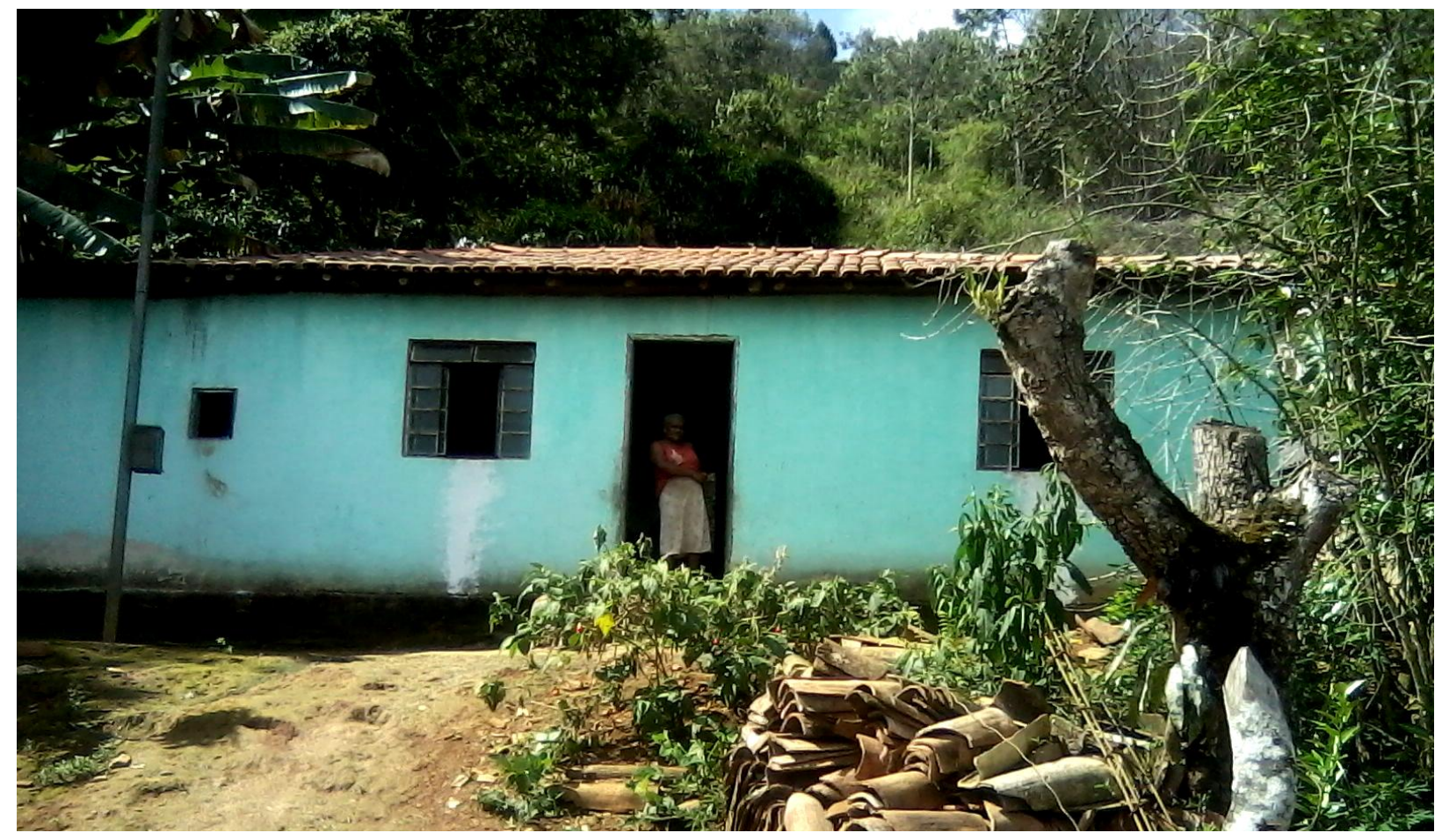

Descendo à vertente, depara-se com um senhor que vinha mancando, rodeado de cachorros, uma foice nos ombros, com um sorriso na largura de seu renascimento. Ele foi baleado na ocasião do conflito pelas terras do Cafundão: um tiro na perna, o faz mancar enquanto assentado em sua gleba. Até graça ele fez, para posar para foto: tire foto do manquinho, tira! 
Figura 26: Senhor que fora baleado na ocasião da violência pela terra do Cafundão. Acervo de pesquisa (2014).

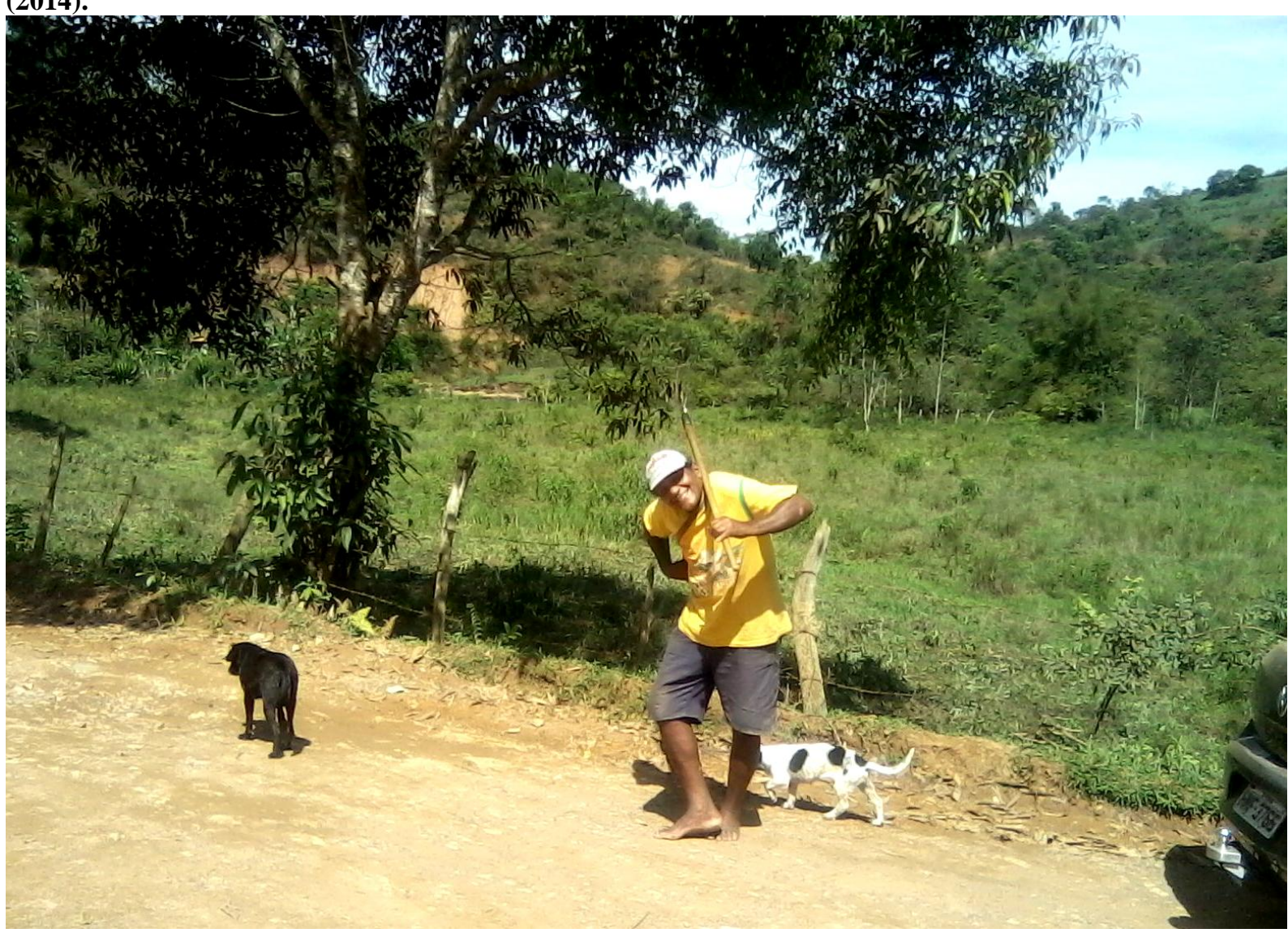

Em uma parada, deparou-se com o momento, bem próximo ao galpão, de pausa para o almoço. O senhor Nilton, que tentava consertar o motor de uma makita, estava sentado rodeado pela opinião de jovens que também descansavam. Vários deles, que possuem parentesco de ser sobrinhos e netos do senhor Adão, oscilam entre o trabalho na Cooperativa e outros fora do assentamento, ligados a empreiteiras, mineradoras e metalúrgicas. O senhor Adão diz que eles não têm paciência de trabalhar com o tempo. A dona Sandra afirma que eles descobrem o mundo maldoso lá fora, com bebidas e drogas, e acabam retornando com a graça de Deus. O assentamento é o meu lugar, diz o senhor Nilton que já saiu para morar em São Paulo.

Figura 27: Reunião dos trabalhadores da Cooperativa ao lado do galpão no pós-almoço. No canto esquerdo, trata-se do pai da pesquisadora, que a acompanhou durante vários trabalhos de campo ao assentamento. Ao seu lado, senhor Adão. Sentado ao centro, com camisa laranja, o senhor Nilton. Os três 
jovens são sobrinhos-netos do senhor Adão, filhos de seus irmãos, alguns já falecidos. Acervo de pesquisa (2014).

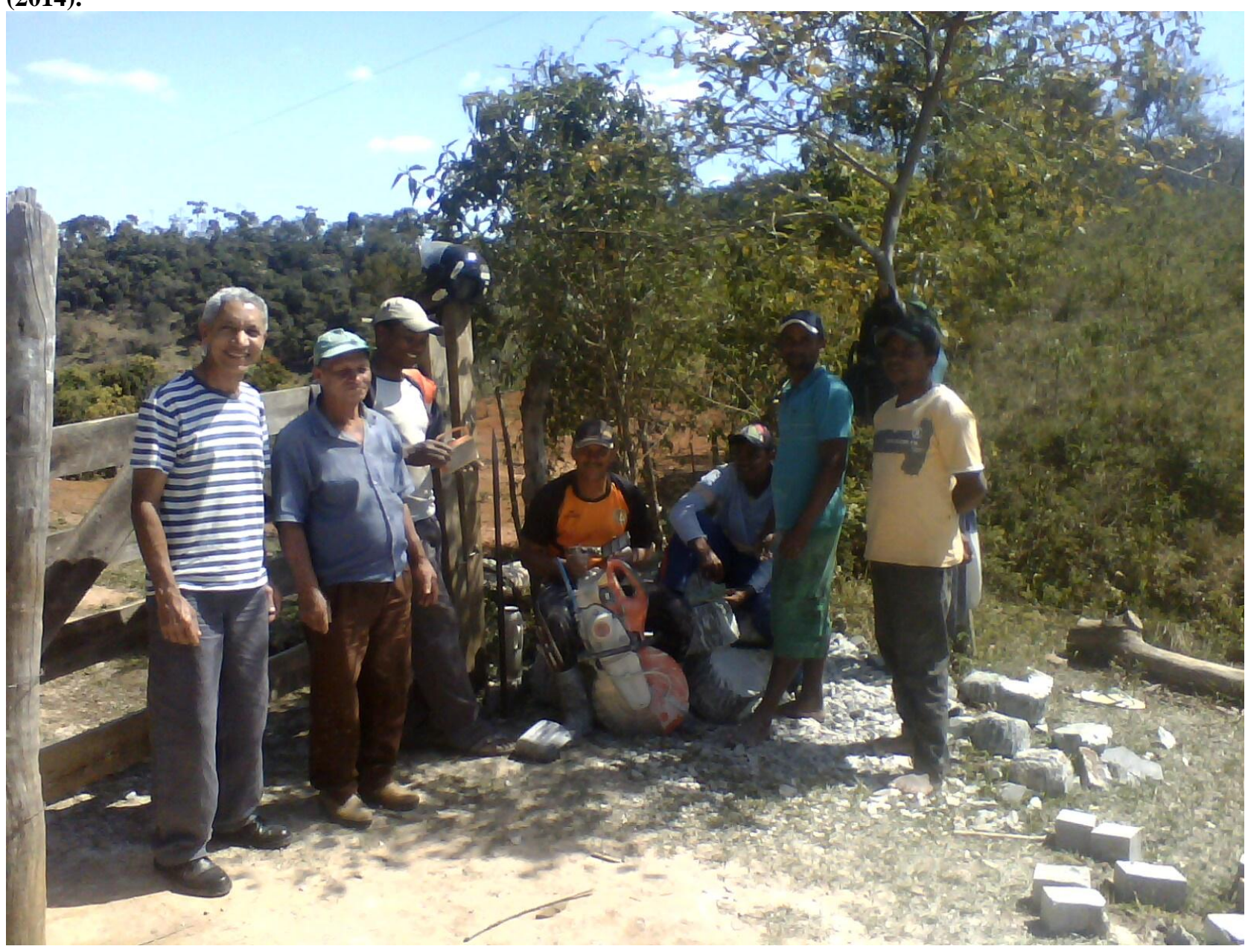

As mulheres e meninas do assentamento ora trabalham em casas de família e fazendas, ora trabalham cuidando de suas próprias terras, crianças e afazeres. Todas as crianças do assentamento estudam no interior do distrito de Cachoeira do Brumado e, quando na fase do ensino médio, levantam ainda mais cedo para pegar um ônibus da prefeitura rumo à sede Mariana.

Dona Sandra menciona que, em fase de chuva, elas precisam leva duas peças de roupa: uma mais velha para se sujar de barro quando andam até o ônibus, e o uniforme escolar para irem limpos para a escola. Criança nossa não vai suja, não! Já os jovens, quando se casam, ganham um pedaço de terra para construir sua casa. A filha do senhor Adão possui o pedaço dela desmembrado da parte do lote seu pai. 
Figura 28: Local onde será construída a casa da filha do senhor Adão, no interior do seu lote do assentamento PA Cafundão. Acervo de pesquisa (2014).

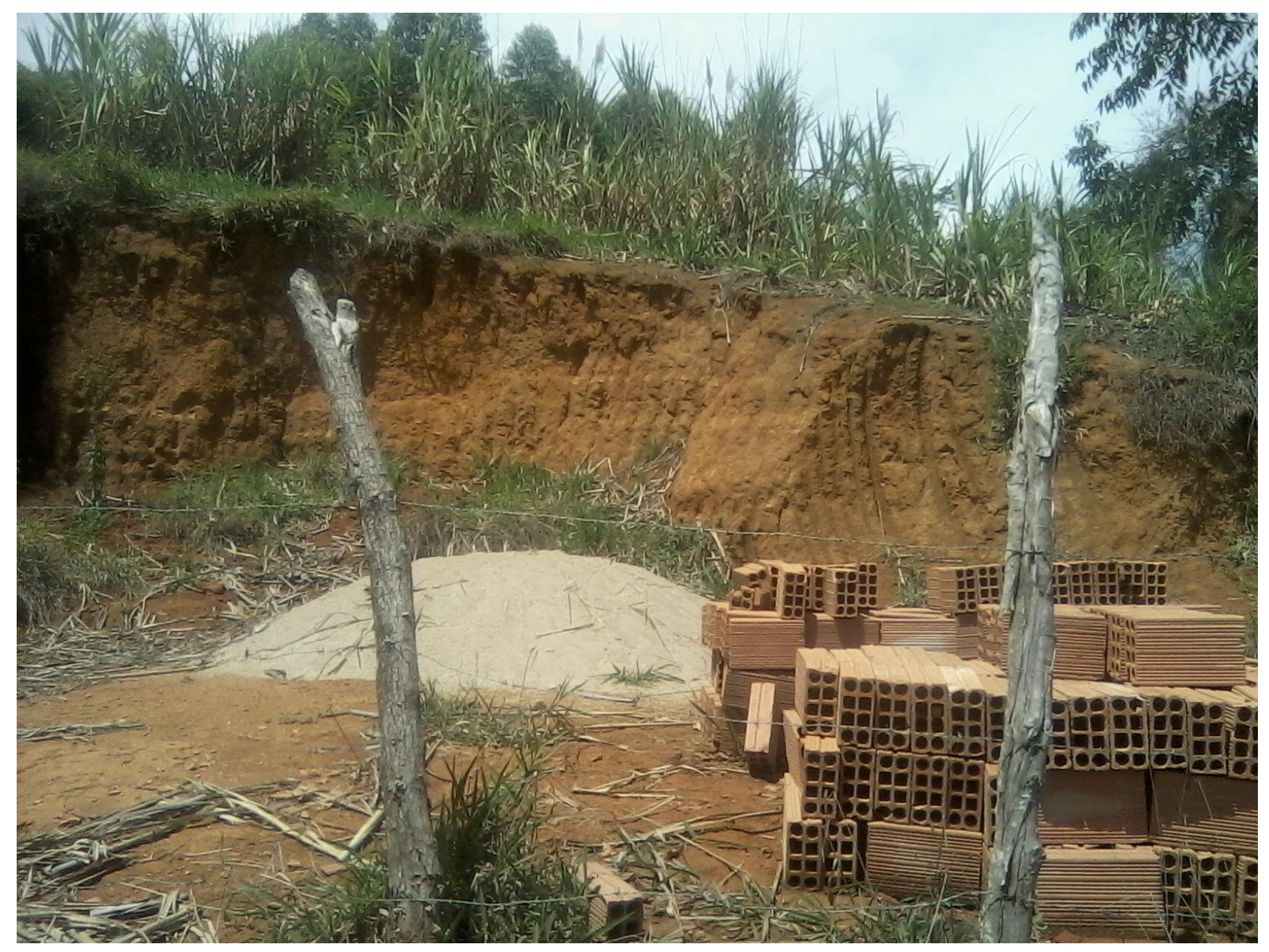

Percebeu-se que a Cooperativa, que abarca o fazer-panela, é também significado de conflito para os adultos e os jovens do assentamento. Ela é, para todos, uma grande segurança, o que se sabe fazer e tem ferramenta para tanto. Mas, a jovem ambição de alçar voos mais altos em relação àqueles de seus pais se distancia do espaço-tempo de produção que foi percebido. E é sobre isso que se atentou o olhar, enquanto se ouvia mais sobre a história de luta pelo Cafundão...

A história de luta pela terra do Cafundão é assumida em seu aspecto de ser somente uma versão dela. Isto por que, se assume que a ordem do discurso escolhida expressa escolhas de pesquisa que foram feitas e que dispõe sobre aquilo que se percebe enquanto pertencente, ou não, a esta versão. Em outras palavras, não se quis construir a História do assentamento 
Cafundão num sentido de ambicionar a passar a representar aquela que detém todas as faces e nuances de uma história, e ser sua frente acadêmica de representação. Neste sentido, a leitura deste escrito seria recoberto de obrigatoriedade àqueles que pretendem também enveredar-se sobre os signos destes assentados em questão. Preocupa-se em explicar que se constrói uma versão pautada em escolhas que foram assumidas, em enfoques trazidos num a priori de um projeto de pesquisa, e em desdobramentos por olhares que foram atraídos, e outros que pertencem a terrenos que não foram explorados.

Ao se realizar a construção de um capítulo inicial dedicado a explanar sobre a amplitude da questão da terra, isso pode ter levado o leitor a pensar que este assentamento seria justamente um contra-movimento àquele que fundamenta a desigualdade no acesso a terra: como assentamento de reforma agrária, ele estaria imerso num discurso de defender uma luta legítima por viver na terra, já que, à imensa maioria de brasileiros, isto é e foi historicamente negado, ou grandemente dificultado. Isto poderia levar o leitor a entender que, enquanto assentamento de reforma agrária, ele compartilha do contexto que fundamenta a criação desta política, abordado no segundo capítulo.

Reforça-se agora que, contudo, estes assentados se unem em uma coletividade de análise oriunda do lutar juntos pela terra do Cafundão, que culminou no ser-assentado de reforma agrária. Por diversas vezes, o ser-assentado torna-se o Outro nesta textualização, no sentido de posicionamento do Eu. Em outras palavras, o Eu se transmuta numa terceira pessoa do singular para se afirmar o olhar de quem pesquisa, para se demarcar que trata-se de uma versão. Neste sentido, a terceira pessoa do singular, no qual está embutida a relação entre a pesquisadora e a orientação, ratifica a alteridade de considerar o Outro sobre o qual se fala. Isto por que, não se pretende falar pelo Outro, ou ser o próprio Outro. O que se tenta realizar é um esforço de diálogo entre o escopo teórico e as impressões percebidas acerca das representações que o Outro faz de sua história de luta pela terra do Cafundão. Desta forma, há uma espécie de tangenciamento entre as impressões realizadas, que já não descrevem um Eu ou um Outro especificamente e individualmente. Trata-se de uma escrita que traduz num entre-lugar (BHABHA, 1998), numa interseção, o encontro Eu-Outro, a fala de um Eu sobre o Outro. A sociogênese advém, portanto, desta interseção.

Senhor Adão, Nilton, dona Sandra, e todos os outros, possuem suas vidas construídas para além de somente resumirem-se a ser assentados, ou seja, há muito mais do que sugere essa coletividade criada no sentido de lutar juntos por uma terra. Este terceiro capítulo 
norteia-se a partir dos elementos apreendidos na sociogênese de luta pela terra, onde o serassentado emerge enquanto mais um elemento na análise da construção do próprio assentamento. Estuda-se pessoas, que possuem memórias, medos, angústias, sonhos. Que vivem suas vidas, constroem esperanças e se esquivam de certas lembranças. O que se estuda está em movimento, pulsa, é vida.

O coletivo inerente ao ser-assentado poderia ofuscar este estudo enquanto representativo das versões apresentadas por todos que são assentados e, mais ainda, poderia estimar um sentido de homogeneidade que é algo que se distancia desta proposta. Cada um se inseriu de uma forma na história de luta pela terra e, vários deles, conhecem as versões que se contam da história por que são assentados através da institucionalização do acesso a terra. Procurou-se respeitar, inclusive, as representações formatadas, que são oriundas da organização social em torno do ser-assentado. Na organização interna do assentamento, há aqueles que falam pelos outros, numa espécie também de liderança, mas que guarda em si uma relação profunda com a própria história de luta. E, por isto, estas elencadas vozes foram ouvidas, mas não em detrimento, e sim numa tentativa de entender mesmo a dinâmica da formatação.

O descolamento realizado pelo senhor Nilton, na saída do Cafundão para São Paulo, e também através de contatos com trabalhadores operários sindicalizados, nutriu sua vontade de organizar as pessoas em prol da luta pela terra, através de resistência, de articulação, e de desenvolver uma capacidade de convencimento inerente a sua maneira acessível e divertida de conversar. A dona Sandra foi a sua grande companheira, e quem representou as mulheres que tentaram iniciar um trabalho com sisal. A filha mais velha deste casal, Patrícia, foi cursar pedagogia no campo com o objetivo de trazer conhecimento ao assentamento. Ela sabe mexer na internet, afirma dona Sandra.

Vários jovens também moraram fora do assentamento, numa tentativa de busca de melhores salários. Estes sempre retornam, por que o saber-fazer panela somado ao seu lar são ainda o alicerce de suas vidas. Alguns guardam uma timidez de uma fala baixa, outros dizem que são bem vividos, que passaram por muita coisa, e a tranquilidade do assentamento não há em local algum.

A memória do senhor Adão, como se tentará dialogar neste capítulo, é um grande marco de relação com a terra. Na terra estão os elementos que incentivam sua memória. A Travessia não se deu enquanto sugestão de atividade a ser realizada: para ele seria 
fundamental conhecer a terra para conhecer a sua própria história de luta. E, mais ainda, havia um elemento crucial para se entender o significado da própria luta pela terra: e ele diz respeito à cerca enquanto expressão da memória territorializada.

Neste terceiro capítulo pretende-se dialogar com elementos percebidos a partir das técnicas e metodologias empregadas, em diálogo com o contexto mais amplo que fomenta o cenário que legitima a reforma agrária. $\mathrm{O}$ viés de escrita deste capítulo irá obedecer ao espaço-tempo de rememoração dos eventos que reconstituem versões da história de luta pela terra. Até este momento, não se elucidará sobre esta escolha na textualização por que ela talvez se descortine no próximo capítulo, dedicado à guisa de conclusão, onde irá se debruçar sobre as construções de espaço que foram percebidas.

\subsection{Exemplificações da criminalização da luta pela terra: a Igreja, o Estado Ditatorial e a emergência do MST.}

O segundo capítulo abordou o movimento curioso por qual passou, amplamente e ideologicamente, a Arquidiocese de Mariana mediante o cenário de atuação da Igreja no país. O processo de redemocratização iniciado com o governo provisório de Tancredo Neves e José Sarney (1985-1990), com a Constituição da República Federativa do Brasil de 1988, e com as eleições de 1990 dando início ao mandato de Fernando Collor, correspondeu simbolicamente a uma inserção mais ampla da Arquidiocese de Mariana nos processos sociais locais, quando esta passa a atuar junto a movimentos sociais, como foi o caso do MAB - Movimento dos Atingidos por Barragens. Enquanto que, anteriormente, em território nacional, a Igreja que lançava mão de artífices contra um Estado autoritário, no apoio, por exemplo, nos anos 19701980, aos Atingidos por Barragens da Hidrelétrica de Itaipu-Paraná ${ }^{49}$, a despeito de defender o direito à propriedade e à família que são noções que atravessam o coletivo social. Por sua vez, esta Igreja passa a se alinhar pós-Constituição a este novo Estado democrático e ao discurso da renovação, como forma de se garantir soberana mediante a aparente abertura religiosa no Brasil, com sua transformação em Estado laico.

\footnotetext{
49 Segundo Stédile e Fernandes (2005), a força social da Igreja (católica) está expresso na própria CPT Comissão Pastoral da Terra - que neste caso específico que se enfoca apoiou grandemente o trabalho do pastor Werner Fuchs, da Igreja Luterana do Brasil, na organização de camponeses atingidos pela barragem de Itaipu, no Paraná, que atingiu abrangência nacional num movimento integrado e, consequentemente, mais forte por que não fora desmembrado em vários movimentos menores.
} 
No relatório da pesquisa Brasil: Nunca Mais ${ }^{50}$, concluída em 1985, especificamente no seu Tomo I acerca do Regime Militar, a Arquidiocese de São Paulo (1985) incita que a esperança da democracia nasceu com o general João Batista Figueiredo quando este assume o poder em 1979 já com o discurso de restabelecer a democracia no país. Nesta pesquisa, a Arquidiocese de São Paulo diz que a repressão aos veículos de comunicação e de forma generalizada àqueles contra o regime continuou até a data de escrita da pesquisa - 1985 -, a despeito da promessa de Estado democrático. Mas, reforça ares de mudança já que este mesmo relatório pudera ser publicado e enviado à sociedade civil, o que carrega um marco de esperança, ainda que ambígua, da democratização. Este relatório não foi construído a partir das denúncias e do que diz as possíveis vitimas e os agressores. Pautou-se numa análise dos documentos produzidos "pelas próprias autoridades envolvidas na ação repressiva", ou seja, é uma tentativa de reconstruir a ação repressiva por intermédio de fonte documental das autoridades repressivas. $\mathrm{Na}$ esteira disso, se analisa a legalidade da ação encoberta pela ideia de seguridade nacional, num primeiro momento, que tensiona com a sua legitimidade, tendo em vista aspectos históricos, políticos e éticos. De forma ampla, tratou-se de "[...] estudo do aparelho repressivo erguido em torno da Doutrina de Segurança Nacional, que por sua vez foi imposta como filosofia oficial do Estado a partir de 1964", periodizando-se até 1985 (ARQUIDIOCESE DE SÃO PAULO, 1985, p. 16).

Segundo Dermi Azevedo (2004), um estudo das relações existentes entre Igreja e Estado revela que fatores políticos foram cruciais para mudanças institucionais da Igreja no Brasil, com destaque para a relação entre o catolicismo e a sociedade a partir de 1964, sob o pós-segunda guerra e regime do Estado Novo. Azevedo (2004, p. 108) enfatiza o "papel das Comunidades Eclesiais de Base (CEBs) como sendo o alicerce do processo de mudança no papel sociopolítico da Igreja”, o que acirra o conflito com o poder político entre 1964-1985, expresso no caráter do referido relatório construído pela Arquidiocese de São Paulo (1985).

Ao analisar a Paróquia de Porto Firme-MG, que pertence à Arquidiocese de Mariana, Oliveira e Schiavo (2008) constatam que durante o arcebispado de Dom Oscar de Oliveira (1960-88), a organização das CEBs e a articulação política dos leigos sofreram resistências

\footnotetext{
${ }^{50}$ ARQUIDIOCESE DE SÃO PAULO. Pesquisa "Brasil: Nunca Mais". São Paulo: Faculdade de Direito da Universidade de São Paulo, Biblioteca Central, 1985. Disponível em: http://www.dhnet.org.br/memoria/nuncamais/bnm tomo1_regime militar.pdf. Acesso em: 15 de janeiro de 2015.
} 
por parte do governo arquiepiscopal, receoso quanto ao perfil contestatório e ao discurso "revolucionário" adotados por muitas dessas comunidades. Porém, as objeções desse arcebispo não foram suficientes para conter a proliferação do modelo de catolicismo na sua Instituição, uma vez que influências externas ultrapassaram seu crivo, "fomentando o germinar das Comunidades Eclesiais de Base nesta Arquidiocese, como aconteceu na Paróquia de Nossa Senhora da Conceição em Porto Firme - MG” (OLIVEIRA e SCHIAVO, 2008, p.02).

Este conflito no interior da Igreja criou um processo de desintegração institucional, expresso na força progressista e tradicionalista no contexto de administração do João Paulo II (1979 - 2005), além do fortalecimento da CNBB - Conferência Nacional de Bispos do Brasil -, criada em 1952, enquanto força política, já que não havia ainda partido político dedicado à defesa específica do catolicismo, ou um partido democrático cristão.

Löwy, por sua vez, parte da premissa de que, após ter sido, durante séculos, a guardiã mais fiel dos princípios de autoridade, de ordem e de hierarquia, a Igreja - ou uma parte dela - tornou-se, quase sem transição, uma força social crítica, um pólo de oposição aos regimes autoritários e um poder contestador da ordem estabelecida. Esse papel ganhou destaque nas décadas de 1970 e 1980 no confronto entre a instituição católica e alguns Estados governados por ditaduras militares, favorecendo a crise de legitimidade desses regimes. (AZEVEDO, 2004, p. 109).

Este autor destaca ainda que os estudos dedicados à investigação da atuação política da Igreja posterior à queda dos regimes autoritários enveredam-se sob três aspectos:

a defesa da justiça social, com a consequente crítica às políticas consideradas neoliberais, de desregulamentação dos mercados e de redução dos gastos sociais, aumentando o processo de empobrecimento da maioria dos latinoamericanos; a defesa da moral sexual tradicional; e a legitimação política e institucional do Catolicismo, diante do Estado, à luz da concorrência das igrejas evangélicas, sobretudo as pentecostais (AZEVEDO, 2004, p. 110).

Diante disso, o princípio de justiça social passa a conviver com os da moral cristã e da ratificação da cristandade e da secularização no seio de atuação religiosa. O que nutre também a coexistência das atuações progressista e tradicionalista no seio do catolicismo. Se no período de retorno à democracia, até 1985, a Igreja se dedica, e conquista também espaço, à luta pela democratização, a partir deste momento tornam-se complexas e heterogêneas suas 
ações, pluralizadas na competição pelo prestígio religioso, dada a oportunidade de criação de partidos políticos, tal como Partido Democrata Cristão (PDC) e Partido Social Cristão (PSC) criados em 1985, e a inserção no cenário político de outras religiões como a pentecostais.

É neste cenário que há o advento daquele que se configura como maior movimento social na luta pela terra, e que obteve apoio da linha progressista da Igreja à sua atuação. O Movimento dos Sem-Terra, hoje denominado Movimento dos Trabalhadores Rurais SemTerra (MST), surge em 1979, também enquanto resposta à falta de atuação já da mencionada $\mathrm{CONTAG}^{51}$ no que concerne à pressão social da terra. João Pedro Stédile - um dos fundadores do MST desde 1979- e Bernardo Mançano Fernandes tentam fornecer a sociogênese da organização MST, a despeito de considerar este contexto tenso, complexo e com elementos que se tangenciam uns aos outros ${ }^{52}$. Neste sentido, primeiramente Stédile e Fernandes (2005) destacam o panorama da agricultura brasileira que começava neste espaçotempo a incorporar tecnologias que substituíram grande parte da mão de obra anteriormente envolvida diretamente nas atividades. Destacam que, na região sul do país, considerada berço do movimento, a soja fora incorporada e até substitutiva de outras culturas anteriormente empregadas, tal como o trigo e o café. Dessa forma, aquela agricultura pautada no uso intensivo - familiar, arrendatária e de parceria - de mão de obra foi se transformando à mecanização, o que expulsou contingentes populacionais que sobreviviam na e da terra.

Estes encaminharam-se, segundo estes autores, para áreas com ocupação mais permissiva historicamente que diz respeito a regiões de fronteira, tal como Rondônia, Pará e Mato Grosso. Porém, a reprodução social destas famílias não conseguiu se manter pautada na agricultura familiar e no cultivo de grãos. Segundo Stédile e Fernandes (2005), isto se deu através também do estímulo governamental às atividades de pecuária e, posteriormente, de garimpo e extrativismo de madeira, além do incentivo à ocupação de terras de fronteira. Como também, o contingente expulso da vida na terra passou a buscar os empregos nas grandes cidades por meio do processo chamado de industrialização que emergia neste cenário. Desta forma,

\footnotetext{
${ }^{51}$ Ao longo da história de construção do espaço brasileiro, surgiram alguns movimentos em prol da luta pela terra, tal como Ligas Camponesas, a União dos Lavradores e Trabalhadores Agrícolas do Brasil (ULTABs) e o Movimento dos Agricultores Sem Terra (Master), que não serão abordados aqui, acerca de sua abrangência e o tempo de atuação, por motivos justificados no texto acerca também da discussão não aprofundada do maior destes movimentos que é o MST.

52 Este livro, denominado Brava gente: A trajetória do MST e a luta pela terra no Brasil (STÉDILE e FERNANDES, 2005), fora resultante de uma entrevista concedida por João Stédile a Bernardo Fernandes.
} 
Do ponto de vista socioeconômico, os camponeses expulsos pela modernização da agricultura tiveram fechadas essas duas portas de saída - o êxodo para as cidades e para as fronteiras agrícolas. Isso obrigou-os a tomar duas decisões: tentar resistir no campo e buscar outras formas de luta pela terra nas próprias regiões onde viviam. É essa a base social que gerou o MST. Uma base social disposta a lutar, que não aceita nem a colonização nem a ida para a cidade como solução para os seus problemas. Quer permanecer no campo e, sobretudo, na região onde vive.

$[\ldots]$

Bernardo [Fernandes]: Os camponeses que perderam a terra e o trabalho por causa da modernização da agricultura passam a se organizar e a resistir?

João Pedro [Stédile]: Sim, porque querem continuar no campo e na região onde moram. É a vocação pela terra. Antes eles eram arrendatários, meeiros, filhos de agricultores que ainda moravam no fim da roça do pai. Agora eles não conseguem mais se reproduzir no campo, estão sendo expulsos da terra. Então resolvem se organizar e lutar para continuar como agricultores nos seus estados de origem (STÉDILE e FERNANDES, 2005, p. 17-18).

Mas, este cenário representou também o da repressão política. Os movimentos sociais que emergiam no campo foram suprimidos e silenciados ora por causa da repressão sofrida, ora por que se vincularam estritamente a um partido, por exemplo ao PTB, e a instituição do bipartidarismo de certa forma enfraqueceu a bandeira. É por este motivo que, Stédile e Fernandes (2005) consideram que o MST seria herdeiro e seguidor da experiência histórica das Ligas Camponesas do Nordeste, que a despeito de terem sido perseguidas pelo regime pós-64, continuaram de certa forma independente - de partidos e sindicados - e se mantiveram com a bandeira de luta Reforma Agrária na lei ou na marra. Além disso, o fato de sua gênese ser considerada como sendo na região sul do país residiria na concentração histórica e socioeconômica dos chamados camponeses nesta região, que possuem a memória da história de luta pela terra. Porém, consideram que o MST surge de forma espacializada pelo território brasileiro, já que haveria também o viés ideológico deste surgimento, para além do socioeconômico.

Neste sentido, ressaltam que o MST “surge do trabalho das Igrejas Católica e Luterana [que desenvolve o trabalho pastoral especialmente junto a comunidades de ascendência alemã, no sul do país, por meio da Pastoral Popular Luterana]. Esse trabalho pastoral das igrejas também faz parte da gênese do MST. E não tem nada a ver com o PTB” (STÉDILE e FERNANDES, 2005, p. 19). Por meio da recém-criada Comissão Pastoral da Terra (CPT), em 1975, há a reorganização das lutas camponesas no Brasil. 
Num primeiro momento ela reuniu os bispos da região amazônica, que percebiam o altíssimo grau de violência cometida contra os posseiros das regiões Norte e Centro-Oeste do país. O surgimento da CPT teve, inicialmente, uma motivação regional. Mesmo assim essa articulação de bispos e de padres ligados à luta pela terra representou, do ponto de vista ideológico, um avanço muito importante. De certa forma, foi uma autocrítica ao apoio da Igreja Católica ao golpe militar, sobretudo em relação aos camponeses. Com o surgimento da CPT, há um movimento de bispos, padres e agentes de pastoral, em plena ditadura militar, contra o modelo que estava sendo implantado no campo.

Outro aspecto importante, com o surgimento da CPT, é o pastoral. Penso que é um elemento importante de aplicação prática do que foi o Concílio Vaticano II e das outras encíclicas progressistas que o seguiram. E que, de certa forma, acabou sendo expresso pela Teologia da Libertação. A CPT foi a aplicação da Teologia da Libertação na prática, o que trouxe uma contribuição importante para a luta dos camponeses pelo prisma ideológico. Os padres, agentes pastorais, religiosos e pastores discutiam com os camponeses a necessidade de eles se organizarem. A Igreja parou de fazer um trabalho messiânico e de dizer para o camponês: "Espera que tu terás terra no céu". Pelo contrário, passou a dizer: "Tu precisas te organizar para lutar e resolver os teus problemas aqui na Terra". A CPT fez um trabalho muito importante de conscientização dos camponeses. Há ainda mais um aspecto que também julgo importante do trabalho da CPT na gênese do MST. Ela teve uma vocação ecumênica ao aglutinar ao seu redor o setor luterano, principalmente nos estados do Paraná e de Santa Catarina. Por que isso foi importante para o surgimento do MST? Porque se ela não fosse ecumênica, e se não tivesse essa visão maior, teriam surgido vários movimentos. A luta teria se fracionado em várias organizações (STÉDILE E FERNANDES, 2005, p. 20, grifos nossos).

Ou seja, para João Pedro Stédile, ainda nessa entrevista concedida a Bernardo Mançano Fernandes, o trabalho da Igreja (católica), que inclusive atuou em vários momentos no apoio a trabalhos realizado pela Igreja Luterana, como também na criação de sua CPT específica para a luta da terra e do trabalhador rural, e na aplicação da chamada Teologia da Libertação; conspirou grandemente à criação do MST e representou o que se chama de autocrítica àquele apoio ao governo ditatorial. Ou seja, influenciou também a situação política de tal época que já reclamava uma abertura, a democratização. A Igreja passa, portanto, de messiânica à mobilizadora social, neste momento. (STÉDILE e FERNANDES, 2005, p. 21). Em cenário nacional, cresce a abrangência de uma Igreja que agora se preocupa e interfere na realidade social, enquanto que o jornal O Arquidiocesano, da Arquidiocese de Mariana, como 
já visto no capítulo 02, expressa justamente uma desvirtuação da mobilização social da Igreja que vinha acontecendo no país em plena ditadura, ao nomear esta prática enquanto ameaça comunista, digna de repressão no interior da própria Igreja e dos fiéis.

De forma ampla, conclui-se que o MST surgiu da mobilização de camponeses que passaram a questionar o direito a terra, por que isso significava inclusive a garantia de sua própria reprodução social enquanto camponeses, influenciados em alguma medida pelos trabalhos que contribuíram a essa mobilização - com destaque à CPT e a Teologia da Libertação, à aglutinação dos movimentos sociais, bem como ao próprio espaço-tempo político sucateado pelo governo ditatorial.

Inclusive, segundo o Relatório Final da Comissão Nacional da Verdade (2014a), em seu Volume I, na Parte IV acerca da Dinâmica das graves violações de direitos humanos: casos emblemáticos, locais e autores - O Judiciário, há dois Capítulos dedicados a explanar sobre a violação de direitos dos camponeses, quais sejam: Capitulo 13 - Casos Emblemáticos, em seu tópico B) acerca da Repressão contra trabalhadores, sindicalistas e camponeses. E Capítulo 14 - A Guerrilha do Araguaia, em seu tópico C) Camponeses e Indígenas. Nesta parte IV do relatório, há a descrição minuciosa de casos que se destacaram dada a monstruosidade da ação repressiva deste Estado Ditatorial.

Este capítulo [13, acerca dos caos emblemáticos] e o seguinte, sobre a Guerrilha do Araguaia, apresentam casos que mereceram um tratamento separado, por serem emblemáticos em relação à repressão contra determinados grupos, como militares e camponeses, ou pela forma como a violência se materializou, como os casos de terrorismo de Estado contra a sociedade civil (BRASIL / COMISSÃO NACIONAL DA VERDADE, 2014, p. 596).

Ao longo desta parte do Relatório, há inclusive uma descrição acerca da repressão ocorrida em 1963, em Minas Gerais, conhecida como Massacre de Ipatinga, na região do Vale do Aço que abrange os municípios de Ipatinga e Timóteo, antes distritos de Coronel Fabriciano. Bem como, há tópico específico que se refere aos apontados pela violação dos direitos humanos e alguns locais onde ocorriam tais repressões no município de Belo Horizonte, além de contabilizarem 25 (vinte e cinco) pessoas mortas ou desaparecidas em Minas Gerais no período de 1964-1985 (BRASIL / COMISSÃO NACIONAL DA VERDADE, 2014). 
Já na pesquisa da Arquidiocese de São Paulo (1985), em seu Tomo III acerca do Perfil dos Atingidos, há a categorização do público alvo da repressão, estando listadas as chamadas organizações de esquerda, nela incluídas os partidos que defendem neste espaço-tempo a reforma agrária, como é o caso do PCB e PC do B. Inclusive, há a descrição da cisão no interior do PCB que culminou, em 1962, no surgimento do PC do B. Como já dito anteriormente, a busca pela legalidade, e isto significou reforçar que não se tratava de partido seção-internacional, e sim um partido que representa causas brasileiras, incentivou a mudança das siglas. Mas essa mudança nas nomenclaturas, segundo o Relatório da Arquidiocese de São Paulo (1985), também significa distinção ideológica entre aqueles fieis ao stalinismo - PCB, do Luis Carlos Prestes - e os outros adeptos de uma nova orientação que leve em conta a pauta capitalista e o desenvolvimento econômico, o fundado PC do B. Essas distinções fez emergir outros partidos, também apontados como alvo da ação repressiva, desmembrados ou dissidentes do PCB, como é o caso da Aliança Nacional Libertadora - ALN, do Partido Comunista Brasileiro Revolucionário - PCBR e da Vanguarda Popular Revolucionária VPR, dentre muitos outros. Destaca-se, ainda nesta parte do Relatório, o Partido Revolucionário dos Trabalhadores - PRT - e o Partido Comunista Revolucionário - PCR, dentre outros, que possuíam membros ligados ao catolicismo, às Ligas Camponesas, e à União Nacional dos Estudantes - UNE, bem como defendiam a problemática do campo brasileiro, através da luta contra o latifúndio, o imperialismo e as condições de trabalho do trabalhador rural.

Em uma divisão por setores sociais, a Arquidiocese de São Paulo (1985, p. 169) elenca seis grupos que eram alvo da repressão, quais sejam: Militares; Sindicalistas; Estudantes; Políticos; Jornalistas; e Religiosos. No interior do grupo Sindicalistas, neste documento está explicado que inclui tanto aqueles que possuíam abrangência urbana, ligados a lutas operárias, quanto "as ações dos trabalhadores rurais envolvidos em conflitos de terras, formação de Sindicatos e organização de Ligas Camponesas”. Além disso, elucida que havia uma espécie de predileção manifestada à punição de organizações sindicais que possuíam pautas não aceitas por este Estado repressivo, bastando a substituição massiva de seus manifestantes à neutralização provisória de suas ações.

Mas considerou-se necessário ir além, invocando a responsabilidade dos envolvidos como violadores de Segurança do Estado, dentro da interpretação que passava a imperar, identificando Governo, Estado, Nação e Forças 
Armadas como uma entidade, uma resposta aos ataques da "subversão internacional”. (ARQUIDIOCESE DE SÃO PAULO, 1985, p. 169).

Percebe-se que aqueles concebidos como relacionados às Ligas Camponesas ou a questões concernentes à reforma agrária foram tratados com "irritação" em vários processos. Foi aberto, inclusive, processo contra a Superintendência de Política de Reforma Agrária SUPRA por subversão da ordem, por "fomentarem a sindicalização dos trabalhadores rurais do interior do Estado [de São Paulo], bem como a ocupação de terras, através do órgão oficial que dirigiam e mediante incitação à luta de classes", além de contribuir para o jornal Terra Livre $^{53}$ (ARQUIDIOCESE DE SÃO PAULO, 1985, p. 174).

A este respeito, o texto temático 03, acerca das Violações de direitos humanos dos camponeses, elaborado pela Comissão Nacional da Verdade (2014b), fornece uma dimensão ampla do que significou lutar pela terra num contexto em que o Estado, através de seus agentes, coloca-se enquanto mantedor da ordem, atrelado ao discurso da moral, da ética, da propriedade e da família. "Ao fazer investigação própria sobre casos de violação e elaborar relatório dos movimentos e entidades, o objetivo é resgatar a memória camponesa a fim de dar mais visibilidade aos sujeitos do campo duramente vitimados pelo Estado e seus agentes entre 1946 e 1988” (BRASIL / COMISSÃO NACIONAL DA VERDADE, 2014b, p. 88).

Este texto temático 03 é dividido em eixos e o primeiro deles diz respeito aos problemas da concentração de terras no Brasil. Neste eixo, há o interesse em "oferecer uma rápida análise das formas tradicionais de resolução e/ou repressão dos conflitos agrários no interior do país", para que se compreenda o "alcance [das] diversas práticas autoritárias que se deram no campo" (BRASIL / COMISSÃO NACIONAL DA VERDADE, 2014b, p. 89). Neste sentido, foram elencadas tipologias que dispõem amplamente sobre os problemas concernes ao conflito agrário, quais sejam:

1.Casos de disputa por terra;

2. Mortos e desaparecidos em cada conflito/circunstâncias das mortes;

3. Disputas localizadas de posseiros vs. grileiros, com participação de agentes do Estado em defesa dos grileiros ou em outros conflitos localizados pela terra;

\footnotetext{
${ }^{53}$ A polêmica relacionada à contribuição a este Jornal Terra Livre se relaciona ao fato de ser publicado pela União dos Lavradores e Trabalhadores Agrícolas do Brasil - ULTAB - com apoio do PCB, entre o período de 1949 a 1964, quando fora proibido.
} 
4. Abusos e violências contra trabalhadores autorizados a cultivar roças dentro de grandes propriedades rurais;

5. Casos de violência em resposta a demandas da Justiça do Trabalho;

6. Grandes projetos do Governo federal que desrespeitaram direitos de camponeses já moradores das regiões ou deslocados para outros estados. Expulsão de posseiros para implantação de projetos governamentais, sem reparação nem direitos. Torturas e mortes de camponeses que resistiram às expulsões. Violação dos parágrafos 12 e 14 do Artigo 34 da Constituição de 1946;

7. Repressão, invasão e fechamento de sindicatos de trabalhadores rurais. Assassinatos de políticos e líderes sindicais;

8. Agenciamento de camponeses sem-terra para trabalho escravo, com cumplicidade de autoridades locais;

9. Criação da União Democrática Ruralista como reação armada de proprietários de terra, alguns com mandatos políticos, contra os movimentos por reforma agrária na década de 1980. Impunidade dos crimes cometidos pelos membros da UDR a pretexto de "defesa da propriedade". Apoio de membros do Congresso a tais ações criminosas. (BRASIL / COMISSÃO NACIONAL DA VERDADE, 2014b, p. 91-93).

O segundo eixo deste texto temático enfoca alguns exemplos de organização de luta pela terra que foram reprimidos por este Estado - que foi inúmeras vezes conivente com a violência na terra. Esta parte, inclusive, fornece dados de espancamentos, casas incendiadas com os seus moradores dentro, torturas empreendidas, agentes estatais coniventes, agentes privados envolvidos, assassinatos, mortos e desaparecidos, etc. Percebe-se a preocupação de dar exemplos da violência de forma espacializada e generalizada pelo território, com descrições de casos ocorridos nas regiões norte, nordeste, sul, centro-oeste e sudeste do país. Já o terceiro eixo abrange o Terrorismo patronal na redemocratização: a União Democrática Ruralista [UDR]. A UDR foi criada a partir da mobilização da elite agrária perante o recente I Plano Nacional de Reforma Agrária - I PNRA, lançado em 1985.

Liderada pelo médico Ronaldo Caiado, de tradicional família de fazendeiros e políticos de Goiás, e pelo pecuarista Plínio Junqueira Júnior, a UDR foi criada nesse estado a partir da movimentação dos grandes proprietários da região em oposição ao PNRA. Tinham como objetivo inicial prestar auxílio legal a seus associados para evitar a desapropriação de seus imóveis, pela nova legislação. No entanto, a versão divulgada pelos movimentos sociais de trabalhadores rurais dá conta de atividades muito distintas. Eles denunciam o envolvimento de seus sócios com "compra de armas e a formação de milícias privadas para enfrentar, violentamente, as 'invasões' de terra", estratégia adotada pelos trabalhadores rurais após a formação do Movimento 
dos Trabalhadores Rurais Sem-Terra (MST). (BRASIL / COMISSÃO NACIONAL DA VERDADE, 2014b, p. 138).

Trata-se de uma organização armada que visa a combater a atuação do MST em prol da reforma agrária, através da distorção de seu método que é baseado na ocupação de terras à pressão social. Os acampamentos, enquanto maneira de fazer ser visto, são denominados pejorativamente de invasões de terra e do ataque ao direito à propriedade. O que se relaciona à temática referente ao quarto eixo deste relatório que diz respeito aos Assassinatos de advogados de camponeses, sindicalistas e membros da Igreja, no qual há a descrição dos casos ocorridos que contribui à noção ampla do que significou e ainda significa a luta pela terra no Brasil mediante repressão, distorção e criminalização.

Porquanto, haveria de se dialogar sobre a herança deixada por este período, especificamente na luta pela terra, somado à historicidade da concentração fundiária e da desigualdade do acesso a terra. Há um imaginário de que o direito à propriedade seria ferido com a reforma agrária, conjuntamente à defesa da família, da ordem e da moral. Há uma outra noção de considerar aqueles que não dispõem de recursos próprios para a terra adquirir ou nela estabelecer enquanto Outros que não deram de forma suficiente o suor de seu próprio trabalho, de forma que medidas assistencialistas estatais iriam contribuir para essa espécie de ócio a eles relegados. A pobreza emergiria enquanto vontade daqueles que querem permanecer pobres.

Mas, este imaginário seria, por vezes, seletivo, na medida em que subsídios a grandes produtores agrícolas não são concebidos enquanto assistencialistas, dado o peso econômico que a agroexportação ainda possui. A luta pela terra ainda carrega imaginários que um estudo mais detalhado deveria descortinar. Imaginários que hoje são lançados também a outros grupos sociais, categorizados enquanto baderneiros, arruaceiros, violentos, invasores, destruidores da ordem pública, pessoas diferenciadas, etc.

Contudo, explica-se que não irá se dedicar ao histórico de atuação do MST, aos assentamentos conquistados mediante a pressão pela terra, e aos diversos acampamentos que se espacializam pelo território brasileiro à espera da concessão. Sabe-se e destaca-se a importância ímpar do MST para as conquistas obtidas na forma de assentamentos de reforma agrária, como também no seio das discussões políticas e acadêmicas acerca da desestruturação agrária-agrícola brasileira. Poderá parecer estranho que esta textualização acerca de uma pesquisa em assentamento de reforma agrária não abarque um viés demonstrativo para com o 
histórico de outros assentamentos. Diferente disso, preocupou-se em expor o cenário mais amplo de onde os históricos individuais são, porventura, deduzidos. Há uma luta pela terra que ainda se dá, por que não se conquistou o direito iminente, reconhecido, legítimo e igualitário para nela viver. Não obstante, o motivo principal de não invocar outros históricos da luta pela terra, relacionados ao movimento social, diz respeito à percepção do papel secundário do movimento social, estando incluso o MST, na memória de tais assentados acerca de sua própria luta. Suas motivações e intenções possuem a noção sim do direito a terra, mas com a peculiaridade de quem viveu naquela, pela qual lutam, durante toda a vida. A história do Cafundão está imersa num sentimento de herança, de justiça e de lugar de vida que serão agora abordados a partir de sua sociogênese.

Como se verá, a instigação que levou com que alguns destes assentados requisitasse ao INCRA (seção Minas Gerais, escritório em Belo Horizonte, a cerca de 130km do Cafundão ) a obtenção das terras do Cafundão para fins de reforma agrária é muito mais ligado à certeza de que estas pertencem de fato a suas famílias, num sentido de herança, do que de forma correlacionada à bandeiras políticas de promoção à justiça social. O segundo tópico apresenta convergências de atuação quando os assentados, no ápice de luta, decidem fazer-se visto na forma da ocupação por meio do acampamento. Acampar torna-se, de forma convergente, o fazer-se visto e um método de pressão social, dada a impossibilidade de resolver o conflito pelas terras através do reconhecimento da identidade territorial daqueles que se tornaram assentados. Contudo, os nomes ligados à bandeira política da luta pela terra, tal como o próprio MST e princípios socialistas de reforma agrária só se expressam de forma secundária nas memórias dos assentados, e não servem à justificação de sua luta pela terra. $\mathrm{O}$ direito a terra reside, neste caso, no direito a continuar seguindo suas vidas, em terras que já seriam suas.

\subsection{As terras do Cafundão enquanto memória e herança}

O encaminhamento para a criação do Projeto de Assentamento Cafundão - PA Cafundão $^{54}$ - é realizado por meio da portaria ${ }^{\circ} 5$, de 8 de fevereiro de 1995 , publicada no

\footnotetext{
${ }^{54}$ Projeto de Assentamento ou PA é uma sigla que designa um assentamento federal.
} 
Diário Oficial da União (DOU) em 16 de fevereiro do mesmo ano. Este assentamento, que passaria a pertencer à Superintendência Regional número 06 (SR-06) do INCRA, que é a seção de Minas Gerais, foi implantado com 12 (doze) unidades agrícolas, às quais os assentados chamam de lote. Há de ressaltar que cada beneficiário submeteu-se ao pagamento do seu lote, com prazos e formas específicas ao assentado de reforma agrária, que reside em "uma política de crédito própria, através do INCRA, que financia a implantação dos lotes, com recursos para a construção da moradia, da manutenção da família no primeiro ano, além de financiar o custeio da produção e disponibilizar crédito para investimento, com prazos e carências" (ALBUQUERQUE et al, 2004, p. 82).

Nós paga ela todo final de ano. Eu não sei pra onde o dinheiro vai, só sei que vai. Nós colocamos no nome do INCRA. É... No nome do INCRA. A gente deposita o dinheiro lá, né? Por que vem o papel deles [boleto] e a gente paga aquele papel lá. Acho que vai pro INCRA. Cada um tem seu lote. Aí, cada um paga sua quantia. [Há prazos de pagamento?] Tem um prazo. Vem agora. Esse final de ano agora, eu termino de pagar meu lote. Aí quando ele veio pra mim pagar no ano passado, eu não tive mil e pouco pra pagar tudo. Aí, então, esse ano eu espero ter... Mas eu vou ter! [Fala da dona Sandra em ocasião de pesquisa acerca de cada assentado possuir o seu lote, que possui dimensões diferenciadas e, por isso, preços diferenciados. Houve a menção de um assentado não ter conseguido pagar a dívida do lote e resolvera vender a outro assentado e mudar-se para a sede de Mariana. Quando questionada sobre o porquê dele não ter conseguido, há a referência em relação a este não ter trabalhado na Cooperativa e nem ter cultivado a terra].

Esta portaria designa 48,4110 hectares da Fazenda Cafundão para fins de reforma agrária, além da necessidade da implantação de infraestrutura física que seria necessária ao desenvolvimento rural, as modificações necessárias que atendem à Divisão de Assentamento, e a comunicação a outros órgãos da existência deste novo Projeto. Neste momento, houve captação de recursos à criação do galpão de torneamento de panelas de pedra, além da intermediação do diálogo entre os assentados para a criação da Cooperativa de Panela, regida por Estatuto específico. Segundo Eloy Alves Filho et al (2007), este seria o menor 
assentamento criado em Minas Gerais até então, que é orientado pela atividade de torneamento.

Este processo de destinação da Fazenda Cafundão à reforma agrária está registrado nos Diários Oficiais desde a vistoria das terras, que se deu em 1992, através da Portaria $\mathrm{n}^{\circ} 9$, de 12 de março de 1992, publicado no DOU de mesma data. Nesta Portaria constam os nomes dos integrantes da equipe, composta por Engenheiros Agrônomo e Agrimensor, encarregada de vistoriar o imóvel rural Cafundão com área de 158,98 hectares.

No ano seguinte, na Portaria nº 32, de 21 de janeiro de 1993 (DOU, 1993a), há o relato de interesse em aquisição de parte da Fazenda Cafundão que foi vistoriada para fins de reforma agrária, que corresponderia, portanto, aos 48,4110 hectares que hoje compõe o assentamento. Neste documento, está descrita a Paróquia de Nossa Senhora da Cachoeira do Brumado como proprietária de tal área, e concordante com a venda destas terras à Autarquia que seria o INCRA, pelo valor de Cr\$42.424.003,64 ${ }^{55}$, que seria correspondente a 101 títulos de dívida agrária $(T D A)^{56}$. Processo consolidado através da Portaria $n^{\circ} 344$, de 24 de junho de 1993 (DOU, 1993b), que emite assinatura de escritura pública de compra e venda do imóvel de parte da Fazenda Cafundão da Paróquia, que seria encaminhado, portanto, em 1995 à criação do Projeto de Assentamento Cafundão.

Será importante frisar que a nomenclatura Projeto de Assentamento ou $P A$ não são assimiladas pelos assentados. Ao contrário, quando se mencionou PA Cafundão ou Projeto de Assentamento eles se mostraram inquietos. O lugar onde moram se chama Assentamento Cafundão. Antes era Cafundão, e agora trata-se de um assentamento. É nítida a forma como ratificam ao Outro a apresentação de si mesmos enquanto assentados do Cafundão.

Porquanto, esta história jurídica fornece somente indícios do conflito existente entre a vistoria realizada na Fazenda Cafundão de 158,98 hectares (DOU, 1992) e a criação do assentamento em área de 48,4110 hectares (DOU, 1995), cerca de 30\% de todo o imóvel rural. Nutre, neste sentido, a mencionada diferença entre as denominações Fazenda Cafundão e PA Cafundão. Como se verá, o INCRA serviu de intermediador do conflito entre aqueles

\footnotetext{
${ }^{55}$ Com base num cálculo simples, realizado no site de finanças IGF, este valor hoje corresponderia a cerca de $\mathrm{R} \$ 15.427,00$ (quinze mil e quatrocentos e vinte e sete reais). Lembra-se que este cálculo desconsidera as possíveis mudanças inflacionárias e de especulação no valor da terra, ao considerar que estas estão fronteiriças ao novo loteamento Bela Ville.

5656 A emissão de Título de Dívida Agrária é, segundo a Lei no 8.629 de 25 de fevereiro de 1993, que regulamenta os dispositivos constitucionais relativos à reforma agrária, uma forma de ressarcir a desapropriação de Imóvel rural que não esteja cumprindo sua função social. Havia regras específicas ao resgate em dinheiro deste pagamento, que pode ser verificado na própria Lei disponível em: http://www.planalto.gov.br/ccivil_03/leis/18629.htm. Acesso em: 21 de janeiro de 2015.
} 
que ocupam a área da Fazenda Cafundão, que diversas vezes são chamados de posseiros, entre aquele - senhor M. - que adquiriu uma fração desta Fazenda através de contrato de compra e venda, e a propriedade jurídica das terras que são da Igreja.

Mapa 2: Delimitação do Projeto de Assentamento Cafundão no interior da Fazenda Cafundão.

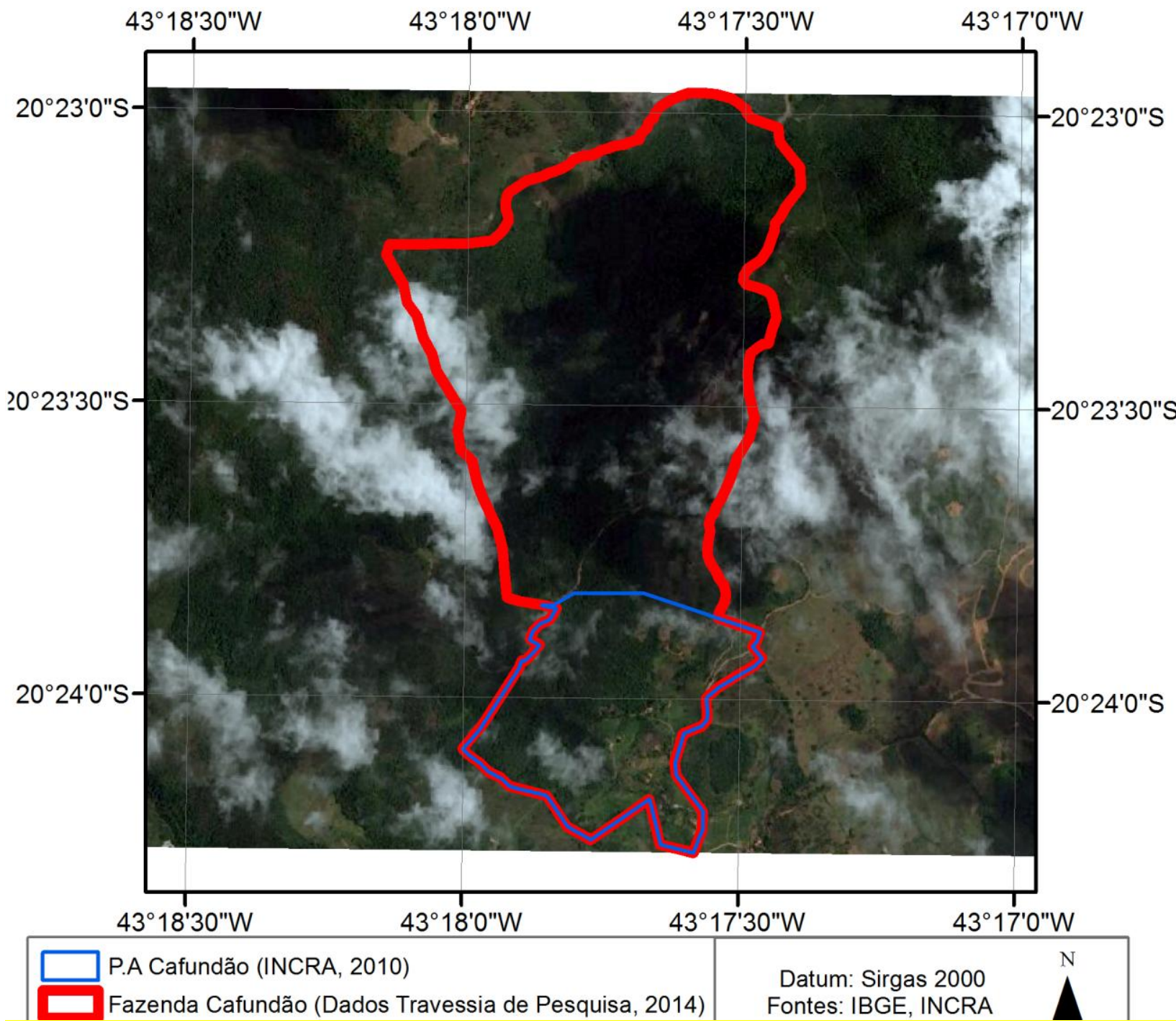


Figura 29: Visão ortogonal da área que corresponde à Fazenda Cafundão (que engloba o assentamento, com dados obtidos da Travessia de pesquisa) e do Projeto de Assentamento Cafundão (INCRA, 2010). Esta visão mostra o aspecto acidentado do relevo, e a área de proteção ambiental que engloba todos os topos das escarpas. Fonte: Google Earth (2015) e base de dados.

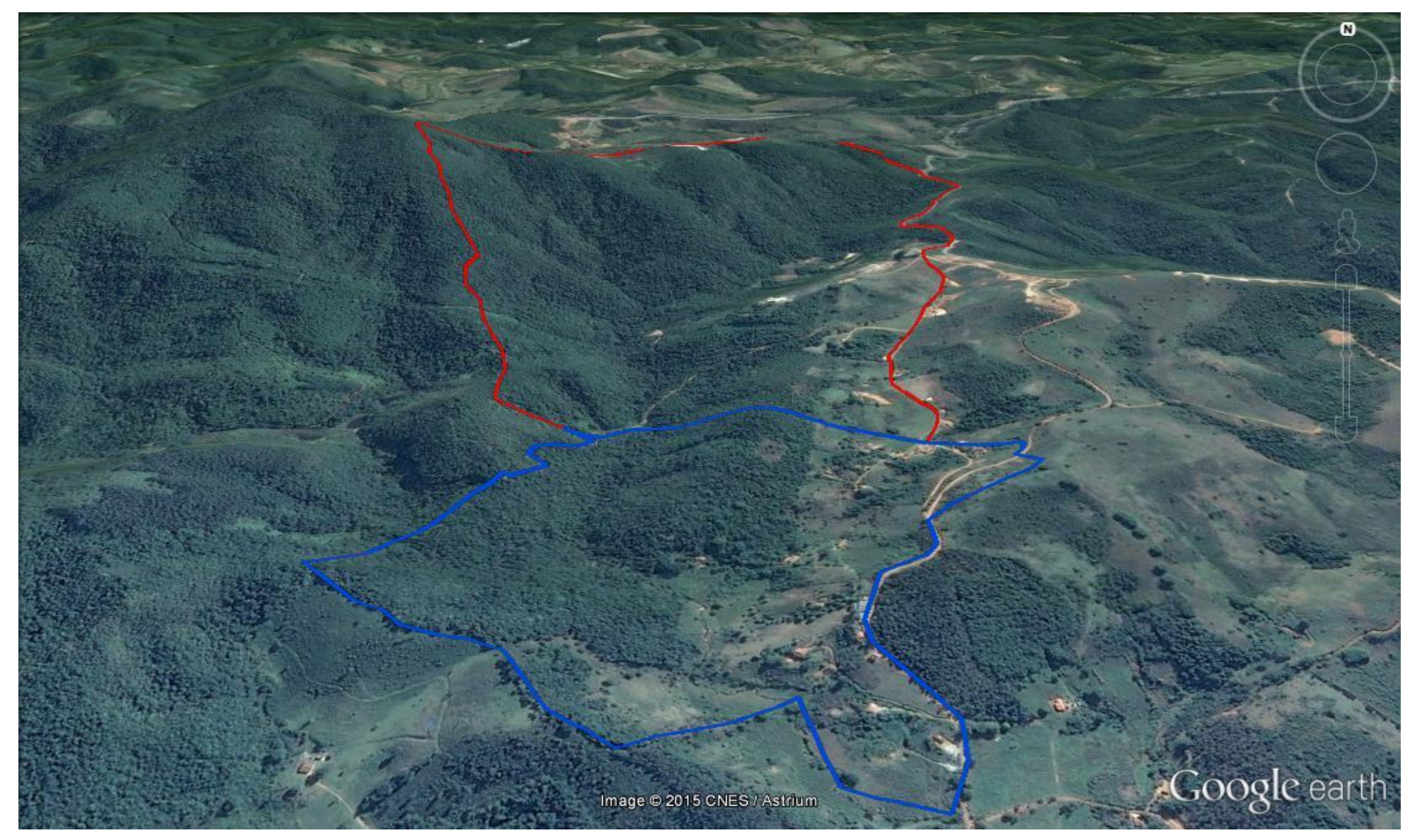

Porquanto, segundo reportagem de outubro de 1990 do jornal O Monumento, expedido pela Prefeitura de Mariana, ou seja, dois anos antes da própria vistoria de 1992, o então Prefeito dessa cidade, Cássio Brigolini Neme, demonstra preocupação com os conflitos existentes na Fazenda Cafundão. Tais tensões estariam se dando entre os habitantes de tal terra, chamado de posseiros, e um "possuidor da promessa de compra da área de propriedade presumida da Mitra Arquidiocesana", que se trata do mencionado senhor M. Para se comprar a Fazenda Cafundão, haveria de se expulsar os moradores locais. O prefeito decidira, diante disso, segundo reportagem, desapropriar tais terras ao atendimento do interesse social, através de

[...] estudo da melhor forma de transferência das terras para os moradores da área $[\ldots]$.

Apesar das providências tomadas pela Prefeitura, a população ainda se sente ameaçada com a presença de homens fortemente armados no lugar, que segundo denúncias feitas na Câmara de Vereadores vigiam todos os movimentos das famílias que vivem na fazenda e impedem os agricultores de trabalharem livremente. Ao receberem denúncias, os vereadores providenciaram a formação de uma Comissão que vai acompanhar todo o 
desenrolar do episódio. Tendo em vista as denúncias de que o delegado de Polícia estava sendo omisso no caso, os vereadores pediram afastamento do policial, através de solicitação de transferência junto ao Governo Estadual (MONUMENTO, 1990, p. 03).

Acerca da ameaça de violência, o senhor Adão reforça que houve ainda o impedimento de passagem nas áreas comuns que são as estradas vicinais e de acesso a terras. A gente tinha que dar volta, ele relata, já que o senhor M. fechara a estrada na altura de sua terra, no topo da vertente. Outro problema relatado pelos senhores Adão e Nilton foi o receio de que o senhor M., ou homens ao seu mando, pudesse contaminar os dois córregos que cortam onde hoje é o vale das terras do assentamento. As nascentes se localizam no topo da vertente, bem próximo a terras do senhor M. Lá lavava roupa, meninos nadavam, tem gente que fazia até comida com aquela água. A gente tinha medo - compartilham das lembranças. Ou seja, era lugar de guerra mesmo, conforme acusou dona Sandra.

Será necessário enfatizar que o nome Adão se fizera presente durante toda a pesquisa e, somente em alguns momentos, esta voz encontra-se em diálogo com outras vozes. O senhor Adão está diretamente relacionado a todo o histórico de luta pela criação do assentamento Cafundão, que foi percebido através da análise e da retomada dos acontecimentos, bem como a partir da percepção da dinâmica interna do assentamento que elenca sua voz - e sua memória - enquanto representativa desta história.

Aliás, esta questão emerge enquanto influência que norteou o fazer da pesquisa de campo. Quando se chegou ao assentamento imbuído da curiosidade acerca de seu histórico de formação, notou-se que o senhor Adão foi imediatamente apresentado enquanto aquele que sabe melhor ${ }^{57}$ da luta, aquele que poderia conversar. Como se verá, a inquietação que provocou a busca por uma via institucionalizada de acesso a terra, que é a política de reforma agrária, advém também do sentimento de herança trazido pela memória do senhor Adão que nasceu e viveu no Cafundão. Além disso, menciona todo o tempo ser descendente de Joaquim Silvério, seu bisavô, que já vivera neste local e também torneava panelas. Percebe-se que o fazer panelas sobrepuja, inclusive, a justificativa de que o senhor Joaquim fosse agricultor e sobrevivesse através do cultivo destas terras, por isso seriam dele por direito de uso. O que se ressalta neste caso da luta pelo assentamento Cafundão, através da memória do senhor Adão e da percepção de que ainda se trata de atividade principal no assentamento, é a relação que

\footnotetext{
${ }^{57}$ Fala do senhor Nilton ao receber a pesquisadora no assentamento e redireciona-la para conversar com o senhor Adão.
} 
estes possuem com o saber-fazer panela. O tornear se instaura enquanto relação íntima com a terra que fornece e aflora o recurso mineral. A relação com a terra possuiria, portanto, significâncias para além de sua face de ser cultivada.

Este relação diferenciada com a terra se expressa na concessão de crédito à criação da Cooperativa e do galpão de panelas de pedra, ao invés de demais incentivos ligados à agropecuária. Aliás, o senhor Adão, atual presidente da Cooperativa, foi percebido enquanto aquele que organiza e incentiva que os homens e jovens trabalhem no assentamento, deem valor ao que já sabem fazer. Este incentivo se expressa na construção do centro comunitário que seria usado a reuniões e confraternizações, bem como no desejo em criar a própria Festa da Panela de Pedra do assentamento, enquanto evento cultural para divulgar o trabalho que desenvolvem. Há uma Festa da Panela, realizada no distrito de Cachoeira do Brumado que está presente no calendário anual do município de Mariana, que atrai turistas e atravessadores. Mas, segundo o senhor Nilton, eles nunca puderam participar desta festa, pois não possuem uma espécie de permissão para tanto. Notou-se que esta permissão é meramente social, e não algo ligado à licença junto à Prefeitura ou ao presidente comunitário. Ao insistir no porque da não participação, já que moram no mesmo distrito, o senhor Nilton ressalta que esta festa não é deles e que um dia eles farão a Festa da Panela do assentamento. O senhor Adão destaca que eles - assentados - já foram beneficiados pelo governo e que, por isso, têm que organizar a festa própria.

Esta relação conflituosa dispõe sobre a tensão percebida entre o Cafundão de Cima que abrange o assentamento - e o Cafundão de Baixo e demais áreas do distrito. A nomenclatura "Cima" traduz não somente a situação geográfica de ocupar uma parte superior da vertente, como também expressa o estar mais próximo ao governo e ser beneficiário de política pública. Integra também o processo de criminalização da luta pela terra que designa aqueles que lutam como aproveitadores e oportunistas. A exclusão dos assentados da Festa da Panela do distrito expressa que estes moradores não integram a vivência daqueles que lá já moravam e se tornaram assentados por uma questão de regularização fundiária. Ao mesmo tempo, que a Festa é o momento da mobilização do Cafundão de Baixo e demais áreas à divulgação de seus trabalhos, já que não possuem apoio do governo. Esta relação se traduz numa tensão curiosa que merecerá melhores aprofundamentos.

Outra expressão percebida é a forma como manifestam que lá em baixo, ou seja, no Cafundão de Baixo, não havia problemas com a Igreja, a despeito de se tratar de terras que 
circundam a Paróquia. Ao indagar sobre possíveis formas que percebem como são vistos pelos que moram no Cafundão de Baixo, dona Sandra diz que eles também já moravam ali, mas aquela parte lá nunca teve problema com a Igreja e nem nada. Aqui que a Fazenda era muito grande. Aliás, é neste momento que se percebe que a Igreja adentra o imaginário dos assentados - através desta fala da Dona Sandra - como aquela que provocou o conflito com eles, já que o Cafundão de Baixo não passou por estes tensionamentos.

[Quem pedia para vocês saírem daqui?] Aí a igreja falou que era deles e que queria a terra. Não queria [que eles ficassem por lá] de jeito nenhum. Nossa, era guerra. [Por que isso aconteceu?] Por que era da Igreja católica. Que tinha documentação, né? Mas, o pessoal antigo aqui também tem documentação. Igual a gente tem uma pasta que tem essas documentações, no cartório também tem, ai não sei o que o INCRA resolveu. Eu tenho pra mim que o INCRA deve ter negociado com a Igreja Católica pra não arrumar confusão... Por que essa terra não foi de graça pra nós. [A senhora havia mencionado que o Cafundão tornou-se lugar de guerra, mas entre quem ocorreu essa guerra?] Entre o povo da igreja católica e os assentados. Por conta, que eles queriam guerra. Aí mandavam fazer as brigas, arrancar cerca, aquelas coisas... Tiro! Todo esse negócio, né? Aí aqui, nós temos ali [aponta] só que tá bem pequenininho a história do assentamento [referente à figura 32]. Nem a polícia quis ajudar. [E quem ajudou?] Um senhor [do sindicato] pegou meu sogro e levou pro INCRA. Aí o INCRA veio pra negociar com a Igreja católica e, depois, ficou pertencendo ao INCRA, aí quando ficou pertencendo ao INCRA, o INCRA foi e aceitou o povo. (Fala da dona Sandra).

Em diversos momentos eles revelam certa inquietação com o fato de a Igreja ter tentado vender estas terras com eles morando nelas. Isto pode ter contribuído, inclusive, para a disseminação da religião evangélica no interior do assentamento. Estes assentados se reconhecem em outra religião, que é diferente daquela predominante nesses domínios regionais e que, ainda, era detentora das terras que eles moravam. São todos praticantes da Assembleia de Deus, que é uma igreja localizada no Cafundão de Baixo. Isto nutre o desejo do senhor Adão de transformar o galpão que possuem em fase de construção, nos fundos da Cooperativa, em uma igreja própria. Pra não precisar descer lá, disse ele. 
Figura 30: Igreja Assembleia de Deus frequentada pelos assentados do Cafundão. Esta igreja se localiza no Cafundão de Baixo, o que nutre a querência pela construção de igreja própria no espaço - cômodo em construção - destinado ao uso comum. Acervo de pesquisa (2015).

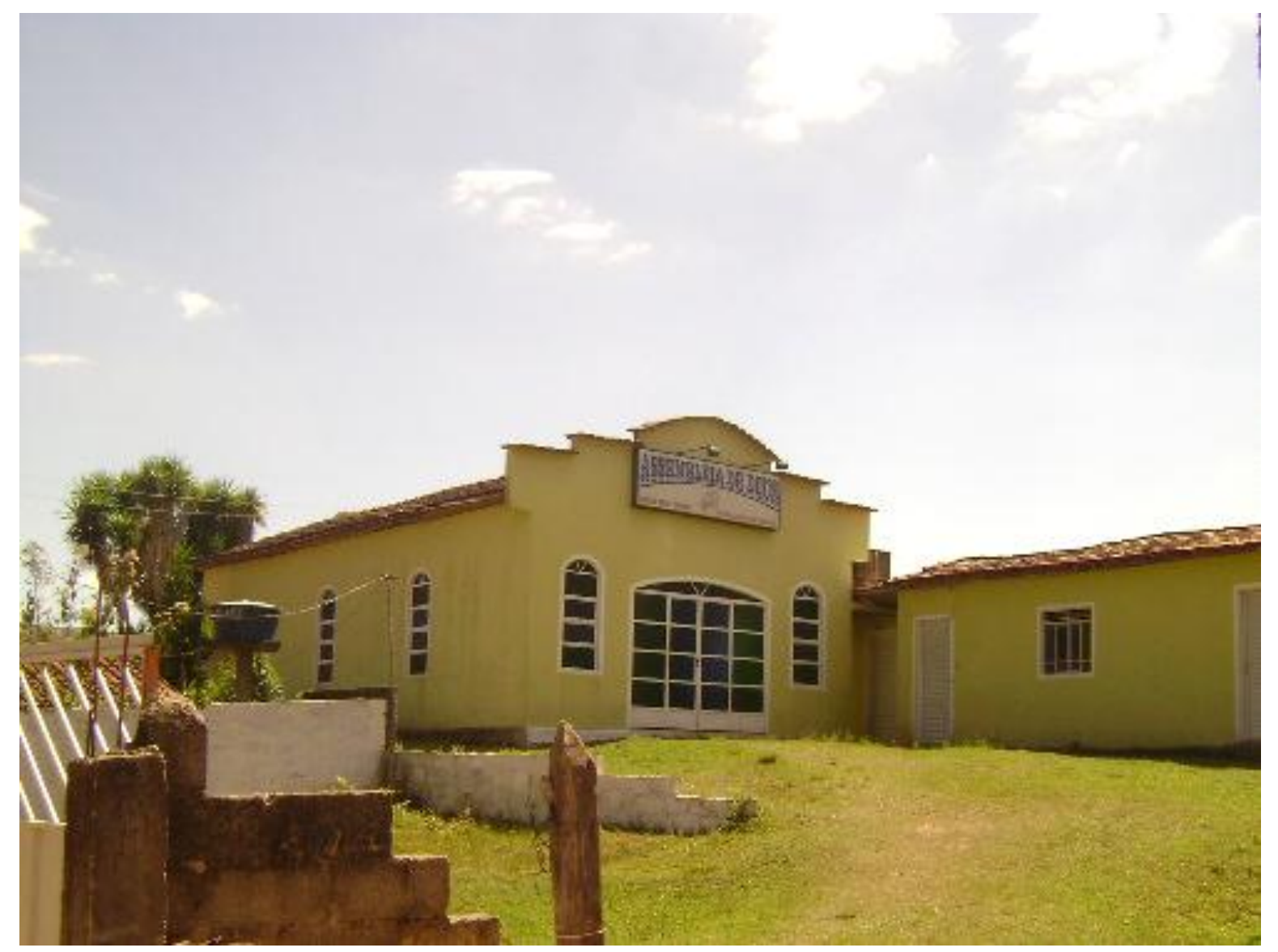

Portanto, a memória do senhor Adão invoca um sentido da relação com a terra que se enfocou nesta pesquisa. Percebe-se sua voz enquanto representativa não somente da história de luta, mas como também da própria formatação de lideranças no assentamento. Outras formas de se chegar ao assentamento, senão acusando interesse pela história de luta, como suposto comprador de panela de pedra, por exemplo, poderia fazer com que o senhor Nilton fosse destacado como o melhor à comercialização de produtos. Percebeu-se que o descolamento por qual passou o senhor Nilton, quando saiu do Cafundão para trabalhar como operário metalúrgico em São Paulo, fez dele o melhor negociador de preços e produtos ao retornar ao Cafundão. Percebem-se denominações que sugerem que ele é esperto, negociador, sabe conversar, sabe dar preço. A sua reterritorialização no Cafundão, ou seja, o seu retorno lhe angariou capacidades inerentes àquele que conhece melhor o mercado, sabe lidar com situações diferentes, conhece melhor o jogo do compra e venda. A sua saída provisória do 
Cafundão contribuiu para a construção do que Rogério Haesbaert (2005) chama de multiterritorialidade, que reside nas vivências múltiplas e na experiência adquirida que torna mais complexo e múltiplo o território-Cafundão. O que contribuiu para que sua esposa Sandra e sua filha Patrícia liderassem, no assentamento, a atividade e comercialização de tapetes de sisal. $^{58}$

Figura 31: Filha do senhor Nilton e da dona Sandra, chamada Patrícia, que ingressou em curso superior de pedagogia do campo na Universidade Federal de Minas Gerais e, também por isso, se afastou das atividades com o tear, que nesta ocasião de visita de campo, ocorrido na graduação no ano de 2010, ela demonstra aos estudantes como construir um tapete de sinal. Acervo de pesquisa (2010).

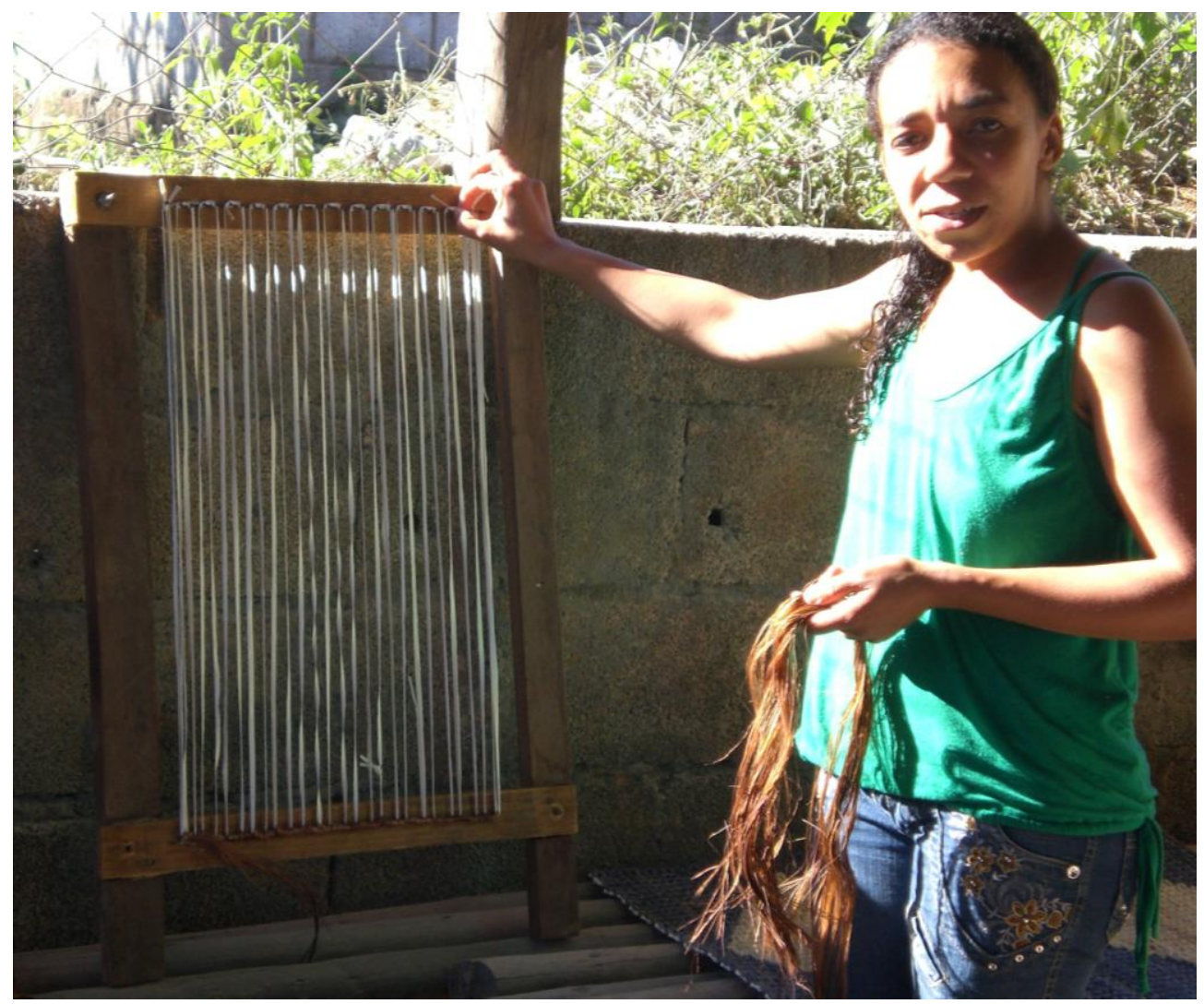

Contudo, apesar da timidez, dona Sandra apresentou o problema de receber cheques sem fundo no pagamento de tapetes, e que requisitava que fosse sempre à cidade - referente à sede - para descontar. Além disso, nem todas as mulheres quiseram se dedicar a esta atividade, que requeria curso para aprendizagem, capital para investimento, e tempo disponível. No começo, expuseram seus produtos em feiras regionais na sede de Mariana e cidades vizinhas, bem como marcaram presença em encontros de assentados de reforma

\footnotetext{
${ }^{58}$ É importante frisar que se possui permissão para mencionar os nomes dos senhores Adão e Nilton, e da senhora Sandra e sua filha Patrícia.
} 
agrária, inclusive em um deles que se deu em Brasília. Em relação à viagem para Brasília, dona Sandra relembra a emoção de ter viajado de avião, e que só ela tivera coragem de ir. Não vendi muito, mas vi tantos trabalhos de assentados! Aliás, a EMATER-Mariana sempre incentivou estas participações, seja no apoio para transporte dos produtos, seja na divulgação do evento. Percebeu-se o papel da EMATER-Mariana como aquela que articula os assentados a oportunidades de exposições e vendas de produtos, assim como, por diversas vezes, esta instituição atuou na representação dos assentados em políticas pertencentes ao PNRA relacionadas à captação de recursos para a Cooperativa. Importância essa sempre ratificada através das falas dos assentados.

Já a Patrícia, a primogênita da dona Sandra e do senhor Nilton, apresenta uma articulação com o público ímpar. Na ocasião da visita de campo realizada em 2010, ela dizia a todos que iria estudar na Universidade Federal de Minas Gerais, e que sonhava em construir uma escola no assentamento. Contou que houvera, anteriormente, uma iniciativa de criação desta escola, mas que durou pouco tempo. Relatou que não havia incentivo para que a professora fosse ao assentamento, tendo que tirar do próprio bolso o dinheiro da passagem. Dona Sandra conta que reaprendeu a ler, e ajudava os outros que não sabiam nada, sabiam menos que ela. Tinham lousa, carteira, estudar era uma festa. Até aqueles que a gente pensava que não iria, ao invés de dormir, tava lá, estudando. A graduação em Pedagogia do Campo reacendia a vontade da escola, na ocasião de 2010. Mas, neste momento da pesquisa, percebeu-se que a Patrícia inseriu-se num processo difícil de rotina, morando sozinha em Belo Horizonte, e necessitando de ajuda das mais diversas para sobreviver. Aliás, esta relação conflituosa nutre o debate da distinção entre urbano e rural que se pauta em sua lógica diferenciada de reprodução das relações sociais (SUZUKI, 2007). A vida de Patrícia tivera que se abrir a uma outra realidade socioespacial que inclui a magnitude do adensamento urbano de Belo Horizonte, conjuntamente às agruras dos que detém poucos recursos e meios de sobreviver em uma grande cidade. O curso de Pedagogia do Campo está neste momento interrompido, a despeito de conseguir transferência para a Universidade Federal de Ouro Preto. Patrícia esta casada, possui três filhos, diz está feliz, apesar de não sobrar tempo para quase nada.

É evidente que esta espécie de conformação de representações ou lideranças, que decidem pelo coletivo que são os assentados do Cafundão, influenciou na investigação, fazendo com que outras vozes fossem subestimadas por eles próprios. Havia uma espécie de 
licença dada ao senhor Adão para falar de sua própria história que se confunde com aquela da luta pela criação do assentamento. Aliás, em todas as visitas de campo realizadas era o senhor Adão quem fazia o acompanhamento, quem direcionava para onde se tinha que ir, para que a memória daquilo que ele contava pudesse ser revivida pelos visitantes que o escuta. As terras percorridas por e com ele se traduziam em sua casa, que ele abria aos visitantes, e revivia a memória presa em cada parede - que na casa-terra está materializada na própria cerca, no sentido dado por Pollak (1989, p. 5) quando afirma que "a memória é assim guardada e solidificada nas pedras”. Percorrer as terras do Cafundão tornou-se incentivo de memória, pois guarda em si a tensão da luta pela terra, o histórico de convívio de toda uma família, a vida vivida e projetada do senhor Adão, de sua família e daqueles que acessaram a terra por meio da política de reforma agrária. Incentivo grandemente provocado pelo elemento da paisagem percebido enquanto crucial à territorialização da memória, que reside na cerca, onde ela está ou onde já esteve - algo que será dialogado no último capítulo.

Aliás, acerca da constituição da memória, ela ocorre por meio sempre de negociação (POLLAK, 1989). A negociação abarca as tensões existentes entre o que emerge enquanto coletivo, aglutinado no que Pollak (1989) designa como denominador comum, e a pluralidade de todas as memórias individuais existentes, à qual Halbwachs (1990) comenta se atrelar à intuição sensível do indivíduo. Neste sentido, “[...] o denominador comum de todas as memórias, mas também as tensões entre elas, intervêm na definição do consenso social e dos conflitos num determinado momento conjuntural" (POLLAK, 1989, p. 4). Além disso, o denominador comum disporia sobre aquelas memórias consideradas oficiais e as outras às quais Pollak (1989) designa de memórias subterrâneas.

Amplamente, este autor fornece elementos para se pensar que, em determinados espaços-tempos, haver-se-ia a constituição mnemônica socialmente aceita, e aquelas outras nutririam as tensões que poderiam provocar, ou não, uma conjuntura. No caso dos assentados do Cafundão, a herança da terra no sentido de ressaltar o direito a viver especificamente nesta terra, pois nela nasceu e se faz panela, é sobressaltado em relação a outras memórias que poderiam descrever históricos de vida peculiares, sensíveis e além-história oficial adotada ou seja, aquela grandemente ratificada a partir da memória da terra que possui o senhor Adão.

Para Jörn Seemann (2003), o processo de construção de memórias - ampliado às identidades - requer espaço para que se edifique, ao mesmo tempo em que a construção de espaço é pautada na memória e na intencionalidade identitária. Há uma relação intrínseca 
entre estes conceitos, que dispõe sobre características diacrônicas e sincrônicas espaciais. A reprodução do espaço se faz por meio de um hoje, de um presente, que expressa uma construção histórica de espaços-tempos anteriores atrelados ao movimento do devir. $\mathrm{O}$ presente torna-se, por isso, movimento. As memórias e as identidades presenciadas, nestes termos, estão em movência, em tangenciamento com aquilo vivenciado no passado, o que se projeta ao futuro enquanto parte da vivência, e a interpretação singular que se quer realizar. Em outras palavras, "a memória constitui um fenômeno particular de correlação, de resgate, de projeção, em suma, de reprodução presente do espaço-tempo em seu devir histórico" (COSTA, 2014, p. 80).

Há interpendências entre as memórias e a construção de espaço que requerem maiores aprofundamentos, inclusive sobre as formas como, de fato, se correlacionam à formação das identidades. Por hora, uma breve análise acerca da formação de memórias coletivas e também das identidades poderia fornecer indícios de como uma análise de espaço requer que o entenda como algo que se expressa como numa sociogênese: ou seja, levando-se em consideração as formas sociais específicas de espacialidade que carecem de mecanismos também específicos de apreensão, inclusive de suas memórias e identidades.

Produzido e organizado de formas diversas pela sociedade, o espaço estimula, também, portanto, diversos olhares e discursos sobre os seus processos de estruturação. [...] A compreensão do espaço, concebido por um imaginário social, demanda uma reflexão sobre suas dimensões simbólica, ideológica, política e cultural. Estudar, portanto, as representações que os homens estabelecem sobre o seu espaço, no discurso literário, é uma maneira de constituir, reconstituir e compreender a cultura de um povo (MELO, 2006, p. 15).

As representações disporiam, portanto, sobre a relação intrínseca entre memória e espaço, que assume formas diferenciadas acopladas no signo cultural de um povo (MELO, 2006). Contudo, cabe destacar o interesse não pelo significado rígido das memórias e identidades coletivas ou pela delimitação empírica de uma coletividade. Em outras palavras, não se pretende verificar - no sentido analítico do termo verificar - até onde as coletividades memoriais dos assentados estão presentes e a partir de onde esse limite-coletivo já não exerce o esforço de unicidade. Há, ao contrário, a pretensão de concebê-las como conceitos moventes, abertas ao diálogo e ao atravessamento. Isso significa que há a pretensão de se aproveitar da mobilidade concernente à expressão coletiva - na análise de memórias e 
identidades -, por esta já se esbarrar por excelência em instâncias individuais e particulares e por ser difícil estabelecer uma delimitação; para entender o seu papel na produção de espaço e na sociogênese do assentamento Cafundão.

De maneira geral, a definição de memória coletiva perpassa o modo como se concebe sua construção. Pollak (1989) aponta alguns posicionamentos de autores que apresentam possíveis significados. Ele remete a Durkheim a definição reificada, e também coerciva, de memória coletiva, através de sua transformação em fato social que explica sua dimensão institucionalizada. Nesse caso, a memória assume a responsabilidade e a função de garantir durabilidade, continuidade e estabilidade a um grupo, ou ao coletivo. Em outras palavras, é por a memória coletiva ser institucional, que ela não é sobreposta pela complexidade de memórias individuais e diversidade dos indivíduos que dela fazem parte e a constroem. Contudo, Halbwachs (1990, p.36), em sua obra sobre memória coletiva, comenta sobre a ideia de "intuição sensível” para indicar aquela memória de natureza estritamente individual por designar a "base da lembrança", que se forma num "estado de consciência puramente individual". Essa memória pautada na intuição sensível embasa a singularidade da memória de um sujeito em relação a outro sujeito. Contribui, portanto, para que as memórias sejam particulares por mais parecidos que possam ser os contextos formadores de memória, ou seja, as trajetórias por quais passam e experienciam tais sujeitos. Pollak (1989, p. 201) destaca também a colocação de Halbwachs quando este defende que a formação de memórias coletivas não ocorre por meio coercivo, e sim através de adesão afetiva, formando "comunidades afetivas". Ao pertencimento a essa comunidade, expresso aqui no serassentado, estabelece-se processos de negociação entre as memórias coletivas e as individuais.

Tem-se, até o momento, duas formas de abordagens em relação à construção de memória: aquela adepta à coerção, e a outra à adesão afetiva. Pollak (1989), em conformidade com Norbert Elias, defende a necessidade de se conceber e permitir o diálogo entre essas duas, que se dão justamente a partir de processos de negociação que entre elas se estabelecem. Por esse motivo, as memórias dos assentados serão entendidas como em processo de negociação, como pertencentes a disputas polifônicas e a conflitos que criam territorialidades de memórias. Haver-se-ia, pois, institucionalizações e adesões afetivas no processo de construção da memória coletiva da luta tensionando com as memórias que cada um dos assentados possui dessa luta. Os processos de negociação de memória, considerando o diálogo entre formas coercivas e afetivas de se construí-la, abarcam a dimensão correspondente à 
microfísica das disputas de poder: "o indivíduo, com suas características, sua identidade, fixado a si mesmo, é o produto de uma relação de poder que se exerce sobre corpos, multiplicidades, movimentos, desejo, forças" (FOUCAULT, 1979, p.161).

Isso significa que as memórias coletivas "não são fenômenos que devam ser compreendidos como essências de uma pessoa ou de um grupo" (POLLAK, 1992, p.205). Elas se constroem, se edificam na vivência simbiótica com o mundo. A esse respeito, Halbwachs (1990) destaca que essa construção de memória correlaciona à construção de espaço que se dá também através da memória, bem como com a construção de identidades que emerge dessa relação.

Já a definição de identidade coletiva é feita por Pollak (1992) de forma correlacionada aos significados de memória coletiva. Esse autor destaca alguns elementos que devem ser considerados como constituintes da memória coletiva e, por consequência, da identidade coletiva, a saber:

1. Acontecimentos individuais que são singulares, o que adentra terrenos da intuição sensível que não se enfocou nesta pesquisa;

2. Acontecimentos vividos por tabela que não quer dizer que o indivíduo tenha, de fato, vivido, mas dele faz parte, impregnando-se num processo de memória herdada. Este processo ocorre por meio da negociação de memória que faz emergir uma identidade socialmente aceita numa conjuntura ou espaço-tempo específico. No caso dos assentados, a história de luta materializada numa lauda escrita pelo coletivo, transcrita a seguir na figura 33, passou a ser a versão oficial que se conta. Adentrar outros terrenos de memória, com detalhamentos daquilo que aconteceu, passou a pertencer ao ser-assentado expresso na figura do senhor Adão, pois é ele quem sabe. Percebeu-se que demais entrevistas realizadas se respaldaram na tentativa de respeitar o limite daquilo instituído enquanto história de luta.

3. Pessoas e personagens, esses últimos pressupondo um processo de identificação com pessoas que não necessariamente fizeram parte da vivência individual, mas possuem significados que criam sentimento de reconhecimento. O senhor Adão fora o único que participou de todas as instâncias de luta: acampamento, conversas com advogados, sindicalistas e movimentos sociais, viagens ao INCRA-MG, tensão pessoal com aquele que os expulsavam, convocações jurídicas. Os demais assentados descrevem a participação destes 
sujeitos de forma a ter conjuntamente ao senhor Adão vivido, porém com um nível de detalhamento mais raso.

4. Lugares que guardam em si mesmos a memória vivida e o significado de se ter vivido, ou seja, as terras do Cafundão enquanto lugar de vivência e incentivo de memória.

5. Datas fixadas em acontecimentos em que, a cronologia do tempo oficial contato em dias, meses e anos se transfigura a fatos que ganham o poder de representar temporalidades. $\mathrm{O}$ senhor Adão remonta os eventos de forma subsequente, e não atrelado à cronologia de meses ou anos. Não se tem uma noção distinta em acusar que algo ocorreu em determinado ano. Era preciso sempre retomar um evento, variar as perguntas, para apreender a ordem do que ocorreu, de forma a adequar ao espaço-tempo documental.

Figura 32: Cafundão, uma história de vida. Narrativa da luta dos assentados pela terra do Cafundão, construída em uma lauda de folha de caderno que está colada na parede da Cooperativa enquanto apresentação ao visitante. Acervo de pesquisa (2013).

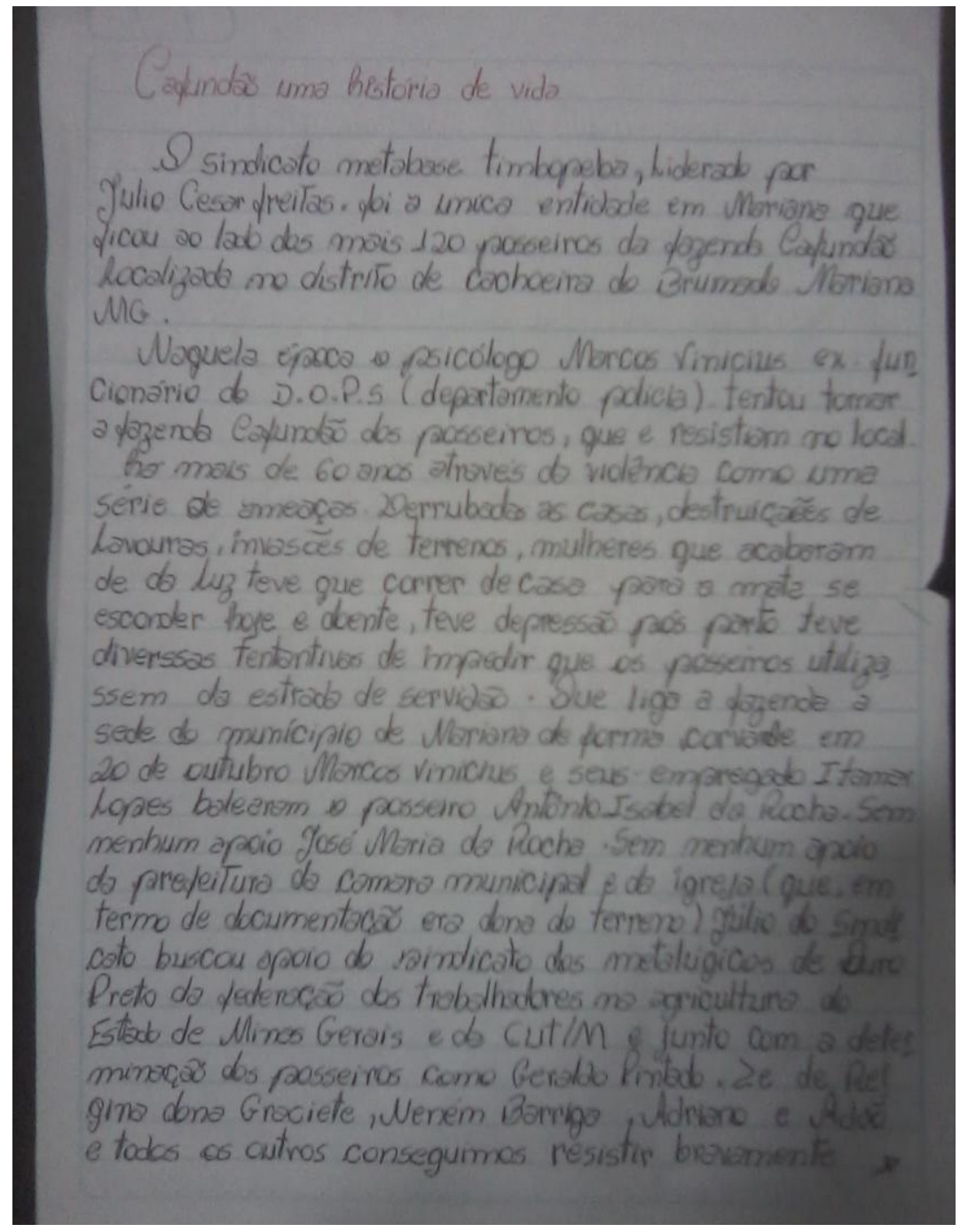


Figura 33: Transcriação da narrativa de luta dos assentados do Cafundão.

Cafundão, uma história de vida..

O sindicato Metabase Timbopeba, liderado por Julio Cesar Freitas, foi a única entidade em Mariana que ficou ao lado dos mais de 120 posseiros da fazenda Cafundão, localizada no distrito de Cachoeira do Brumado, em Mariana, Minas Gerais.

Naquela época, o psicólogo [senhor M.], ex-funcionário do D.O.P.S (Departamento de Polícia) tentou tomar a fazenda Cafundão dos posseiros que resistiram no local.

Há mais de 60 anos através da violência como uma série de ameaças, derrubada de casas, destruição de lavouras e invasões de terrenos. Mulheres que acabaram de dar a luz teve que correr de casa para a mata, para se esconder hoje é doente. Teve depressão após parto. Teve diversas tentativas de impedir que os posseiros utilizassem a estrada de servidão, que liga a fazenda à sede do município de Mariana.

De forma covarde, em 20 de outubro [senhor M.] e seu empregado balearam os posseiros Antônio Isabel da Rocha e seu filho João Maria da Rocha.

Sem nenhum apoio da prefeitura, da câmara municipal e da Igreja (que, em termo de documentação era dono do terreno), Júlio Cesar buscou apoio do Sindicado e da Federação dos Trabalhadores na Agricultura do Estado de Minas Gerais [que mobilizou o MST] e junto com a determinação dos posseiros [...] resistiram bravamente.

Desta forma, com muitas lutas, foi conquistada a desapropriação daquela terra para Incra sendo; Fazenda Cafundão entregue para os posseiros. Esta luta conquistou, também, um financiamento para construção da cooperativa da fábrica de panela sabão pelo Incra.

A luta da Fazenda Cafundão é um exemplo vivo de só o povo pobre e trabalhador unido mobilizado pode conquistar seus direitos e avançar na construção de uma vida melhor.

Percebe-se, pois, que a identidade, em consonância com Pollak, se relaciona tanto com o diálogo entre as memórias individuais e as coletivas, como com os processos de reconhecimento ou de identificação com pessoas, personagens, espaços e tempos. A identidade é construída a partir justamente da produção do espaço, que possui especificidades e particularidades que dispõem sobre sua formação. Pollak (1992) destaca elementos que 
fazem parte da construção social de identidade que se resumem à unidade física, que se refere ao sentimento de pertencimento ao grupo; à continuidade temporal, ou seja, a resistência ao tempo; ao sentimento de coerência que está na unificação de elementos que formam os indivíduos; e à ratificação do Outro, como forma binária de também se assumir enquanto Eu, pois "ninguém pode construir uma auto-imagem isenta de mudança, de negociação, de transformação em função dos outros" (POLLAK, 1992, p. 205). Para Everaldo Costa (2014, p. 82), "a identidade é enraizamento, é sobreposição de objetos e ações e identificação com estes mesmos elementos".

Portanto, é imperativo considerar que os processos formadores de memórias e de identidades em suas extensões coletivas absorvem as especificidades e complexidades que são inerentes e que norteiam a noção de sociogênese na análise de fenômenos sociais específicos, que nesse caso é a luta pelo assentamento Cafundão. Os processos de negociação de memória que elenca o senhor Adão enquanto liderança integra a própria sociogênese do assentamento. Quando se realizou uma visita de campo, na entrega de um banner enquanto parte da devolutiva aos assentados, deparou-se com uma situação em que o senhor Adão não estivera presente, pois estava cuidando do neném, conforme afirma senhor Nilton. Tratava-se do seu mais novo filho, nascido a poucas semanas, de seu segundo casamento. O senhor Nilton recebeu o banner e articulou toda a conversa, em que os seus três sobrinhos fizeram parte. Era um domingo, e estavam todos de folga à espera do atravessador que viria levar as panelas. Indagou-se sobre os tempos de luta, e eles respondem entre risos que a luta ainda continua. Tem que vender, pra comer, afirma o jovem à direita da foto que interrompe a conversa com a indagação: que time cê torce? A partir deste momento, o campeonato brasileiro de futebol motivou uma conversa de horas. Não se percebia intenção ou satisfação alguma em retomar o assunto que fora cortado.

Outros assentados, em sua maioria pertencente à família do Adão, ora se afastavam, ora se aproximavam quando o assunto não era a própria história de luta. A única assentada que manifestara alguma espécie de vontade de estar conversando sobre aquilo que viveu foi justamente uma senhora, de mais ou menos 50 anos, casada com o sobrinho do senhor Adão, e que tivera, por consequência da luta, uma espécie de doença psicológica que poucos mencionam, mas que fora percebido em um copo d'água oferecido no interior de sua casa. A narrativa acerca da luta que esta senhora faz ainda é repleta de medo, agonia. O senhor Adão conta que ainda hoje ela dá trabalho. Ouve barulho, corre pra mata. Ele se refere aos 
episódios de violência em que os homens permaneciam na linha de frente, encarando aquele terceiro, senhor M., que os ameaça com armas e cachorros de guarda. Enquanto que as mulheres se refugiavam vertente à baixo, numa área de mata ciliar, hoje área de proteção ambiental do assentamento. E isto se reproduziu por meses, até intervenção da Câmara, do Sindicado METABASE, e do INCRA. Porém, esta mencionada senhora por vezes ainda procura no meio da mata pelo seu filho perdido, que estar-se-ia trabalhando nos arredores de Mariana, em empreiteiras ligadas à mineração - e retorna toda tarde, dorme em casa.

Figura 34: Senhor Nilton, com o banner da pesquisa, e seus três sobrinhos que trabalham na Cooperativa de Pedra, e esperavam juntos o atravessador para vender as panelas, num domingo no mês de setembro. Ao fundo, a Cooperativa. Acervo de pesquisa (2014).

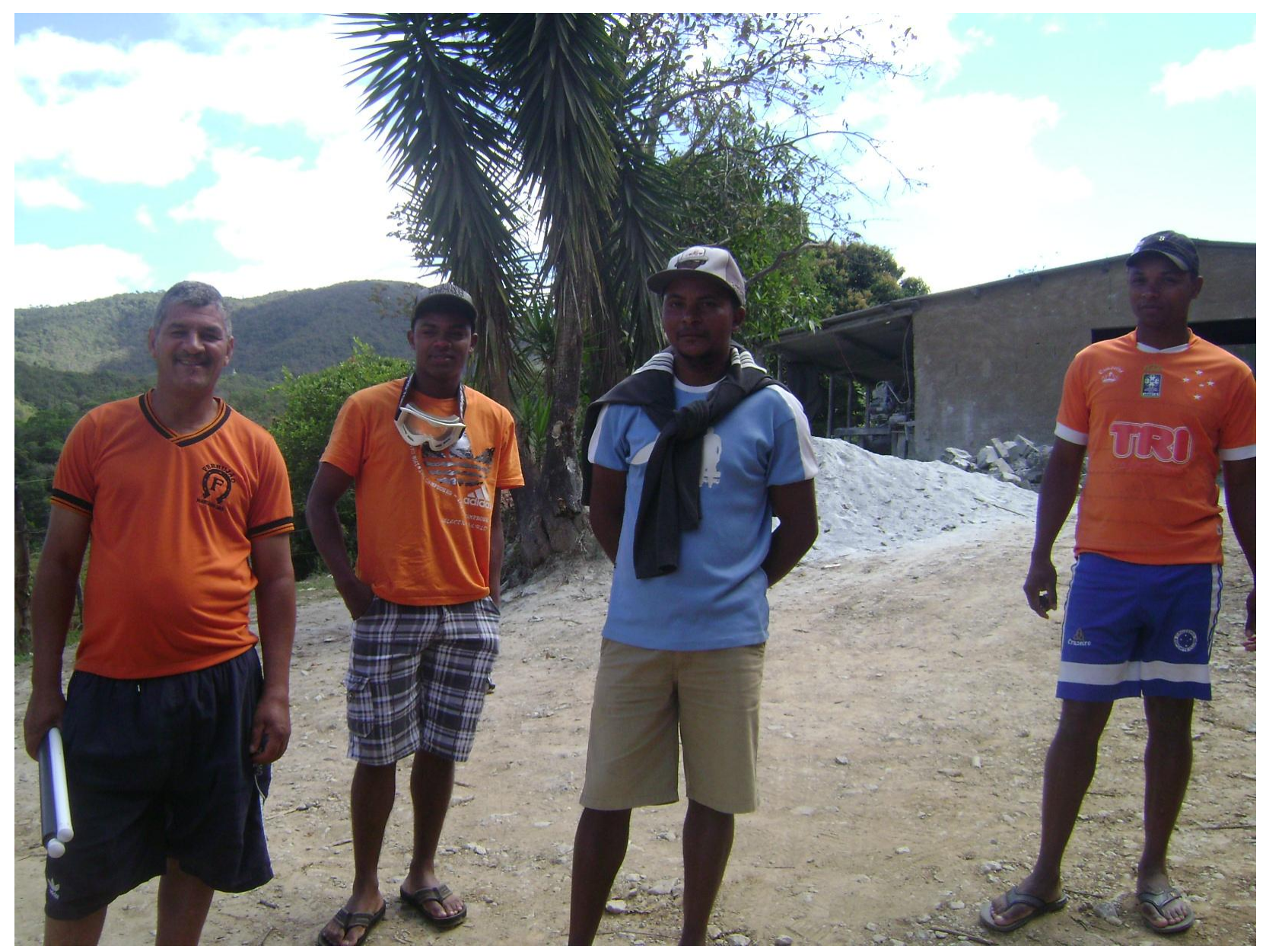

Longe de qualquer afirmação referente a somente o senhor Adão ter vivido ou construído por si próprio os acontecimentos relacionados a estes conflitos, o que se percebeu, ao longo da pesquisa, foi que a memória do senhor Adão, revivida de forma tensa a ponto de 
arrancar-lhe lágrimas, está imersa num sentimento de justiça não realizada contra as terras que foram de seus pais, de seus irmãos, de seu bisavô como herdeiro legítimo. Durante toda a conversa, ele retoma que seu pai é Francisco da Cruz de Oliveira, neto de Joaquim Silvério de Oliveira, dono destas terras. E que terceiros, aos quais ele denomina como gente que tem nada a ver, quiseram se apropriar indevidamente, expulsando-os, queimando suas casas, não fazendo jus aos papeis que ele tinha. Percebeu-se uma noção de que as terras onde moravam estavam e ainda estão circundadas por grandes fazendeiros que compõem ou influem na política marianense, inclusive já tendo sido prefeitos da cidade. Na história reproduzida no assentamento, a despeito de ela parecer um tanto quanto confusa, há o apontamento de ter havido outras pessoas na tensão da luta pela terra, às quais denominam de jagunços e coronéis, ao mesmo tempo em que reforçam o caráter culpabilístico da Igreja pelos conflitos. Bem como, apontam que oscilava a maneira como eram recebidos, quando reclamavam pela resolução da tensão instaurada no assentamento, conforme o governo que presidia a Prefeitura Municipal de Mariana.

Aliás, será preciso salientar também que o senhor Adão recebeu a ideia desta pesquisa de uma forma que soou a um alívio. Nas intermitências dos encontros, em períodos que não se estava em campo, o recebimento foi sempre no sentido de agradecer por não se ter sumido. Durante a pesquisa, descobriu-se que a Universidade Federal de Ouro Preto realizava trabalhos conjuntamente aos assentados, numa linha de economia solidária. Verificou-se fotos que registram, inclusive, que houvera há uns dois anos antes uma mobilização com maior número de assentados presentes e participantes de dinâmicas. Algo não conquistado por esta pesquisa. A equipe de tal instituição era composta por técnicos, engenheiros e estagiários, e também promessas.

Como parte destes trabalhos, houve o incentivo para que os assentados desenvolvessem a psicultura, ou criação de peixes, dada a disponibilidade de água no terreno. Construiu-se dois tanques, um para reprodução e o outro para engorda. Um deles foi aterrado, e o outro segue-se numa criação doméstica e subestimada de peixes. Quando indagados sobre o porquê de não ter ido para frente essa ideia, ficou evidente ter faltado assistência técnica sobre como criar e comercializar este novo produto. Pode ser que tenha faltado uma iniciativa que potencializasse algo que eles já sabiam fazer, ou a iniciativa integrada de ensinar uma nova atividade, a fim de promover, de fato, algum desenvolvimento local. 
Figura 35: Fotografia do senhor Nilton lendo o banner construído nesta pesquisa como parte da primeira devolutiva. Na ocasião, explicou-se que a história de luta ainda estava em processo de escrita, e como promessa de retorno e um agradecimento, este banner foi realizado. Fotografia extraída do site INCOP Empreendimentos. Disponível em: http://www.incop.ufop.br/index.php/galeria-cafundao/category/14; Acesso em: 21 de janeiro de 2015.

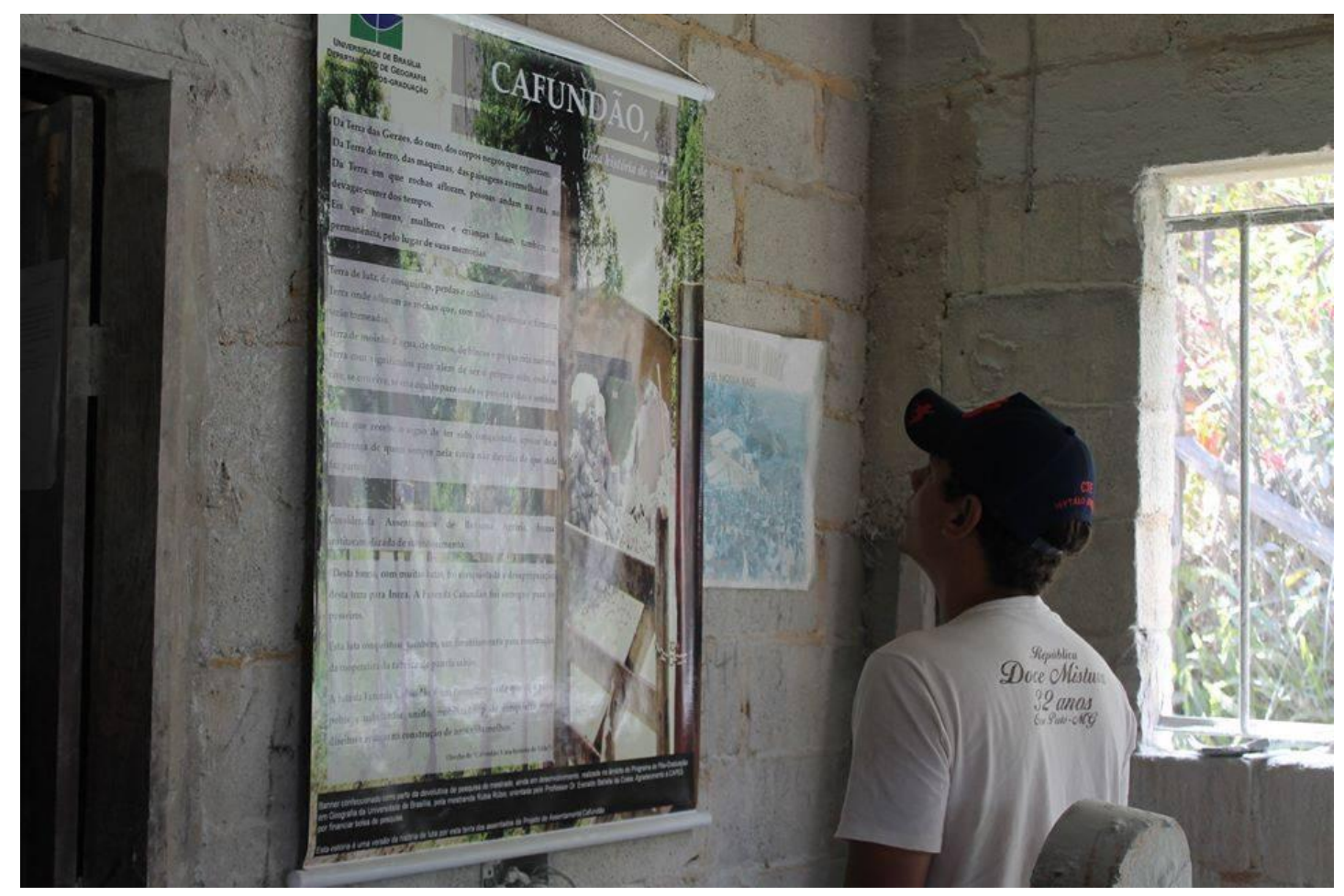

Assim como, em anos antes, em 2006, houve o desenvolvimento de um projeto de Arranjo Produtivo Local (APL) promovido por um Centro Tecnológico localizado na capital do Estado, para tornear a pedra à confecção de panela. Porém, percebeu-se que este torno está subestimado, e o motivo diz respeito ao funcionamento exclusivo a tampas de panela, que ainda permite uma certa produção em série. Este torno não permite que quem o está manuseando torneie conforme deseja. Ele possui uma espécie de trava de encaixe que segura o bloco e o torneia quase que de forma igual todos os blocos. A tentativa foi produzir duas panelas em um só bloco: na extremidade sairia a panela maior, e em seu centro, uma panela menor, o que contrasta com o aspecto artesanal da panela de pedra de ser lapidada com o tempo e o jeito necessário para tanto. Cada panela é uma panela. A tampa ainda dá pra fazer um monte. 
Figura 36: Fotocópia do banner entregue aos assentados do Cafundão em setembro de 2014.

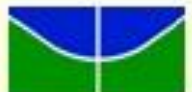

Univeramdade de Braglula Defartaniento de Geografia

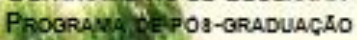

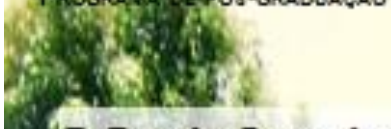

Da Terra das Geraes, do ouro, dos corpos negros que ergueram.

Da Terra do ferro, das máquinas, das paisagens avermelhadas.

Da Terra em que rochas afloram, pessoas andam na rua, no devagar-correr dos tempos.

Eis que homens, mulheres e crianças lutam, também na 23. permanência, pelo lugar de suas memórias.

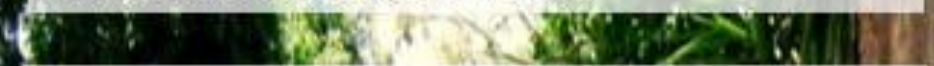

Terra de luta, de conquistas, perdas e colheitas.

Terra onde afloram as rochas que, com mãos, paciência e firmeza, serão torneadas.

(19)

Terra de moinho d'água, de tornos, de blocos e pó que cria nuvens. Terra com significados para além de ser o próprio solo, onde se Q. vive, se convive, se cria aquilo para onde se projeta vidas e sonhos.

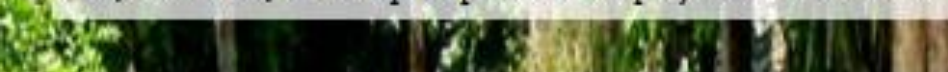

14. Terra que recebe o signo de ter sido conquistada, apesar de a 1) Iembrança de quem sempre nela viveu não duvidar de que dela 3. faz parte.

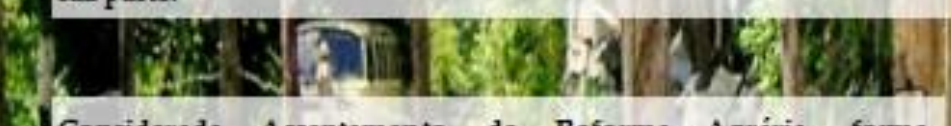

Considerada Assentamento de Reforma Agrária, forma institucionalizada de reconhecimento.

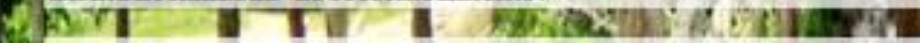

"Desta forma, com muitas lutas, foi conquistada a de sapropriação desta terra para Incra. A Fazenda Cafundão foi entregue para os posseiros.

Esta luta conquistou, também, um financiamento para construção da cooperativa da fábrica de panela sabão.

A luta da Fazenda Cafundão é um exemplo vivo de que só o povo Thobre e trabalhador unido, mobilizado, pode conquistar seus 23 direitos e avançar na construção de uma vida melhor."

is

Trecho $\Delta e$ "Cafundio, Uima himbria $\Delta s$ Vids")
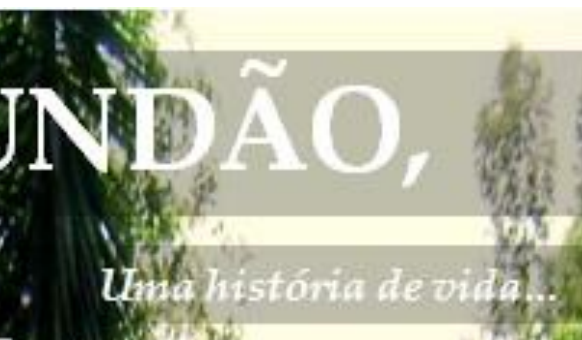

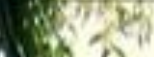

100

$4 x^{2}$ in
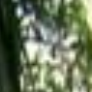
axpsy

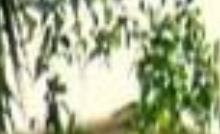

西
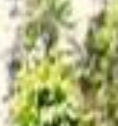

$20 y$
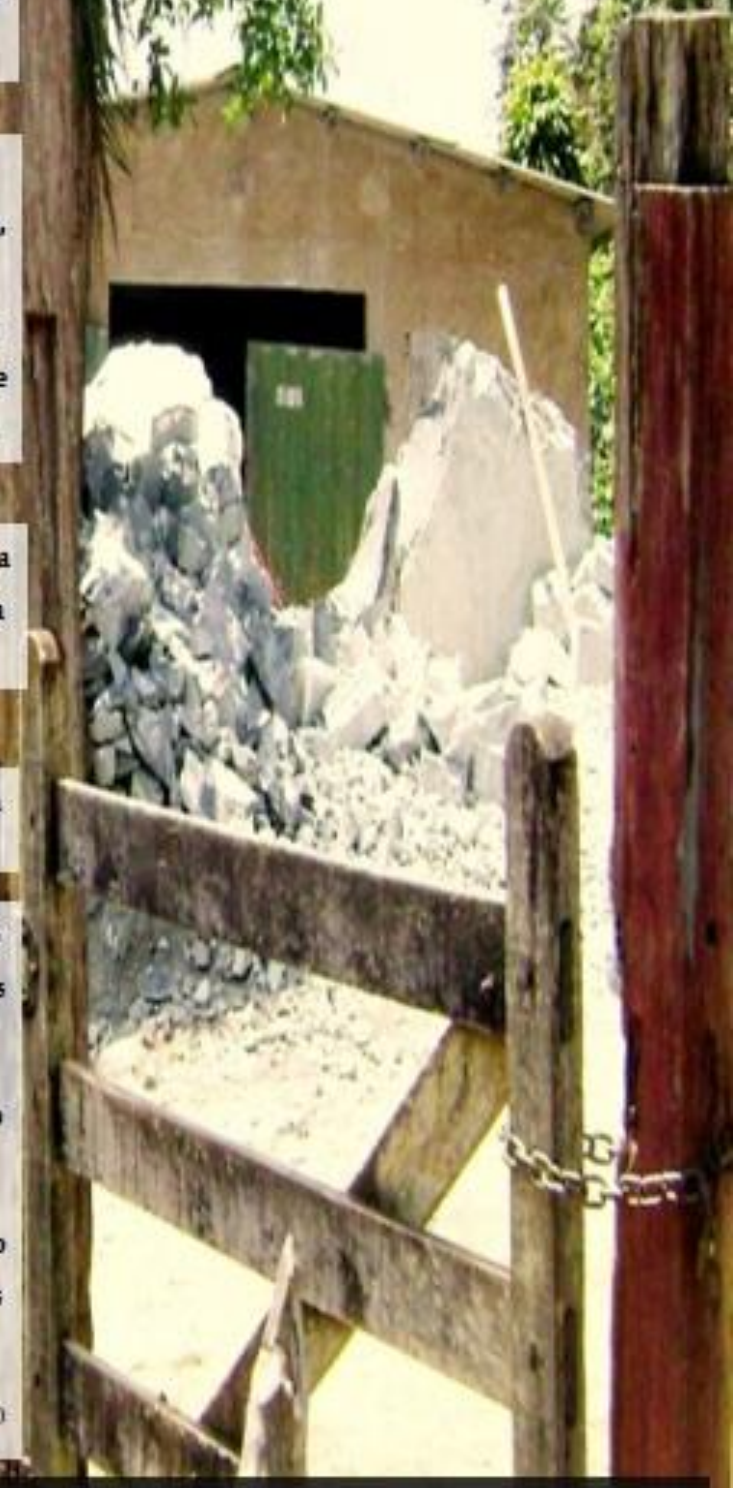

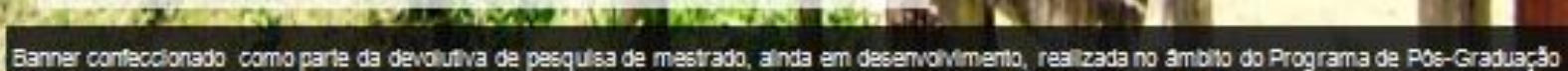

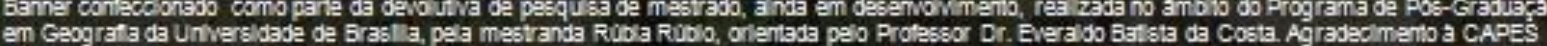
por finandar bolsa de pasquisa.

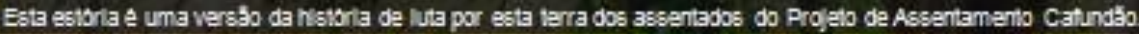


O receio do senhor Adão em relação ao Outro que vai até o assentamento para realização de trabalhos foi sentido. E, por isso, esta pesquisa foi devidamente explicada enquanto algo limitado à história de luta. Os outros assentados não tensionaram com a ideia de que o senhor Adão falava por eles enquanto assentados. E assim se prosseguiu, na tentativa de encontrar com os demais ao percorrer, por meio da Travessia, as terras da Fazenda Cafundão e do assentamento.

Porquanto, no segundo campo - sendo que o primeiro se resumiu à apresentação e ao interesse da pesquisa -, por volta do terceiro dia consecutivo em que se foi ao assentamento, foi entregue um envelope pardo que consolidava a confiança que o senhor Adão depositara na pesquisa. Trata-se de alguns documentos antigos que ele entregou xerocados por que ai você vai conseguir fazer a história. Por que vai andar pra traz e vai lá no Joaquim Silvério. O Senhor Adão desejava que se percebesse que a terra do Cafundão haveria de ser sua por herança, por que foi deixada por Joaquim Silvério de Oliveira que é seu bisavô, e ele haveria de ser o único ainda vivo.

Isto porque, Joaquim tivera dois netos, Francisco da Cruz de Oliveira e Jovelino Silvério de Oliveira. Um dos documentos entregues pelo senhor Adão diz respeito a uma declaração de doação que Jovelino realiza para Francisco. Trata-se de uma declaração, certificada em cartório, com data de 31 de dezembro de 1974, em que Jovelino, denominado como lavrador e solteirão, doa sua parte no terreno herdado de Joaquim para seu irmão Francisco. Ou seja, em 1974, Francisco da Cruz de Oliveira toma posse de todo o terreno que pertenceu ao seu avô, Joaquim Silvério de Oliveira. Quando indagado por que um irmão doou tudo para o outro, o senhor Adão fala que é preciso ter filhos para tocar uma terra, e Jovelino era solteirão.

Há uma emissão de título particular de posse no qual consta que Francisco da Cruz de Oliveira tornou-se ainda donatário de Antônio Filomeno de Araújo e sua esposa Izabel Pereira de Araújo, lavradores, em 1957, antes de receber a doação de seu irmão. Nesse título, há o reconhecimento de que estas terras doadas por Antônio e Izabel fazem divisa com aquelas que pertenciam a Joaquim Silvério, mencionando que Joaquim já possuía herdeiros habitantes no local. Como também, está relatado que há frações pertencentes à Paróquia Nossa Senhora da Conceição, numa localização no topo da vertente, na cabeceira dos córregos Bota Fogo e Fôrno de Telhas. Este título de donataria foi realizado mediante o pagamento oficial de quatro 
mil cruzeiros ( $\mathrm{Cr} \$ 4.000,00)$, e mais algumas sacas de milho que fora mencionado pelo senhor Adão.

A partir de 1974, ano de doação da herança de Jovelino ao Francisco, há cópia de recibos de quitação do Imposto sobre Propriedade Territorial Rural - ITR, que reconhece algum tipo de propriedade, ou título de domínio, ou possuidor de qualquer título sobre o imóvel rural. Em tais certificados, Francisco da Cruz de Oliveira possui a situação jurídica de "real posse" de "minifúndio", com área de 19,6 hectares, ou seja, conforme o Decreto n 55.891 , de 31 de março de $1965^{59}$, esta fração diz respeito a uma área inferior a um módulo fiscal. A este respeito, a Empresa Brasileira de Pesquisa Agropecuária - EMBRAPA, subordinada ao Ministério da Agricultura, Pecuária e Abastecimento - MAPA, evidentemente apoiando-se em decretos e resoluções, considera o Módulo Fiscal (MF) como "unidade de medida agrária que representa a área mínima necessária para as propriedades rurais poderem ser consideradas economicamente viáveis" (EMBRAPA, 2012 p. 07). Desta forma, propriedades com até um (1) módulo fiscal seria classificado como minifúndio, seguido das pequenas propriedades, médias propriedades e grandes propriedades. Para se fazer um comparativo atual da diferença do valor do módulo ao tamanho do imóvel rural, tem-se a tabela abaixo que compara o tamanho das propriedades nos municípios mineiros de Mariana, onde se localiza o assentamento Cafundão, Belo Horizonte, capital do Estado, e Buritizeiro, com maior número de hectares por módulo fiscal, localizado no norte de Minas a $175 \mathrm{~km}$ de Montes Claros.

O latifúndio, por exemplo, enquanto maior imóvel classificado, conforme o artigo 22 do Decreto $\mathrm{n}^{\mathrm{o}} 84.685$, de 06 de maio de $1980^{60}$, possuiria o tamanho superior a 600 (seiscentas) vezes o número de hectares por módulo fiscal do município. No caso de Mariana - Minas Gerais, segundo a Federação da Agricultura e Pecuária do Estado de Minas Gerais FAEMG (2014) ${ }^{61}$, o número de hectares a ser considerado um módulo fiscal neste município é de 20 (vinte) hectares. Ou seja, a classificação de latifúndio para o município de Mariana é de 12.000 (doze mil) hectares, o que contrasta com o latifúndio belo-horizontino que é de

\footnotetext{
59 Regulamenta o Estatuto da Terra. Disponível em: http://www.planalto.gov.br/ccivil_03/decreto/19501969/D55891.htm. Acesso em: 21 de dezembro de 2015.

${ }^{60}$ Regulamento a Lei $n^{\circ}$ 6.746, de 10 de dezembro de 1979, que trata do Imposto sobre a Propriedade Territorial Rural - ITR e dá outras providências. Disponível em: http://legis.senado.gov.br/legislacao/ ListaTextoIntegral.action?id=102455\&norma $=125907$

${ }^{61}$ Documento elaborado pela FAEMG (2014) que contém o número de hectares para ser considerado um módulo fiscal em todos os municípios de Minas Gerais. Disponível em: http://www.faemg.org.br/Web/File s/24104420415935551141282041622080192226.pdf
} 
3.000 (três mil) hectares, e o de Buritizeiro que é de 42.000 (quarenta e dois mil) hectares.

Neste sentido, é possível deduzir que a dedicação de determinado município à agropecuária influencia, evidentemente, em seu módulo fiscal. Bem como, áreas com densidade urbana como seria a de Belo Horizonte possui módulos fiscais menores, em relação ao município de Buritizeiro, com dedicação à agropecuária, numa área de mais de 7 mil km² - sendo o quinto maior município mineiro - com uma população de 26.922 habitantes ${ }^{62}$.

Tabela 4: Classificação de tamanho de imóveis rurais nos municípios de Mariana-MG, Belo Horizonte e Buritizeiro, com base nos módulos fiscais destes municípios.

\begin{tabular}{|l|c|c|c|}
\hline $\begin{array}{l}\text { MUNICíPIOS / } \\
\text { TAMANHO DO IMóvEL RURAL }\end{array}$ & $\begin{array}{c}\text { MARIANA } \\
\text { (ha) }\end{array}$ & $\begin{array}{c}\text { BELO HORI- } \\
\text { ZONTE (ha) }\end{array}$ & $\begin{array}{c}\text { BURITIZEIRO } \\
\text { (ha) }\end{array}$ \\
\hline Módulo fiscal para cada município & 20 hectares & 05 (ha) & Até 70 \\
\hline Minifúndio (até 1 módulo fiscal) & Até 20 & Até 05 & $>70$ a 280 \\
\hline Pequena propriedade (1 a 4 módulos) & $>20$ a 80 & $>5$ a 20 & $>280$ a 1.050 \\
\hline Média propriedade (maior que 4 a 15) & $>80$ a 300 & $>20$ a 75 & $>1.050$ a 42.000 \\
\hline Grande propriedade (maior que 15 até 600) & $>300$ a 12.000 & $>75$ a 3.000 & $>42.000$ \\
\hline
\end{tabular}

Tabela elaborada pela autora. Os Módulos Fiscais dos três municípios mineiros foram extraídos de FAEMG (2014) que elenca 20 hectares para Mariana, 05 hectares para Belo Horizonte e 70 hectares para Burizeiro. Já a classificação do tamanho do imóvel rural através do módulo fiscal é definida por EMPRAPA (2012). Este cálculo, realizado pela autora, baseou-se no módulo rural de cada município através do intervalo que consta na classificação da EMPRAPA (2012), através da multiplicação do módulo pelos intervalos mínimo e máximo de cada intervalo de tamanho de imóvel rural. Onde o símbolo ">” significa maior que.

Porquanto, foi entregue cópia da comprovação de pagamento do imposto - ITR realizada por Francisco da Cruz de Oliveira no período de 1976 a 1984. No pagamento referente ao ano de 1976, há o enquadramento sindical enquanto trabalhador rural. Já a partir

\footnotetext{
62 Dados retirados do IBGE em sua plataforma@Cidades. Disponível em: http://www.cidades.ibge.gov.br/. Acesso: 22 de janeiro de 2015 .
} 
de 1981 até 1984, tem-se o registro sindical de empregador rural, mas com nenhum assalariado registrado. Além disso, a expedição do documento é a partir deste momento realizada com a seguinte descrição: "um exclusivo cadastral tributário não legitima direito domínio e posse".

Já no ano de 1994, dez anos desde a última cópia de pagamento do ITR que se tem nesta pesquisa, há o pagamento do espólio de Francisco da Cruz de Oliveira. Somente a partir da análise deste documento, entendeu-se a fala do senhor Adão que diz respeito ao seu pai ter falecido sem ver tudo resolvido. O assentamento em 1994 estava em vias de criação, e através do espólio sabe-se que Francisco falecera em algum ano anterior a esse. O senhor Adão constrói sua narrativa por meio da sucessão de momentos, e não se pretendeu investigar qual ano, de fato, ocorreu o falecimento do senhor Francisco. Portanto, a ocupação destas terras permeia a história da própria família do senhor Adão, enquanto anfitrião do local. E também por isso, por este histórico de ocupação, a Assembleia Legislativa do Estado de Minas Gerais (1992) denomina esta tensão enquanto impasse.

Foi adiada para a próxima semana a apresentação do relatório final das atividades da Comissão Especial que analisa os conflitos de terra em Cafundão, região de Mariana. Ontem, os Deputados Marcos Helênio e Maria José Haueisen, ambos do PT, respectivamente, Presidente e Relatora da Comissão, admitiram a dificuldade de resolver o impasse, defendendo, no entanto, uma posição mais efetiva do INCRA. (ASSEMBLEIA LEGISLATIVA DO ESTADO DE MINAS GERAIS, 1992, p. 08).

Este impasse pode ser melhor compreendido através de certidão emitida pelo Serviço Registral de Imóveis (COMARCA DE MARIANA, 1991), que foi um documento também entregue pelo senhor Adão. Com data de 30 de dezembro de 1991, o senhor M. compra da transmitente Paróquia de Nossa Senhora da Conceição de Cachoeira do Brumado da Arquidiocese de Mariana uma área correspondente a 26,60 hectares. Essa terra possui registro datado de 1769, menos de vinte e cinco anos depois da elevação de Mariana à cidade, e escritura lavrada em 1917. A descrição da área, que foi comprada pelo senhor M. por um milhão de cruzeiros (Cr\$1.000.000,00), é realizada com base em marcos e estações, que são medidas usadas no registro de imóvel rural deste cartório, bem como por elementos geográficos que permitiram visualizar que tais terras hoje estariam no interior da Fazenda Cafundão, no topo da vertente, adentrando-se o atual loteamento Bela Ville. 
Mapa 3: Localização do Distrito de Cachoeira do Brumado em Mariana (Google Earth, 2015) com destaques temáticos para a sobreposição de terras do imaginário da Fazenda Cafundão e o que pertenceu ao senhor M.

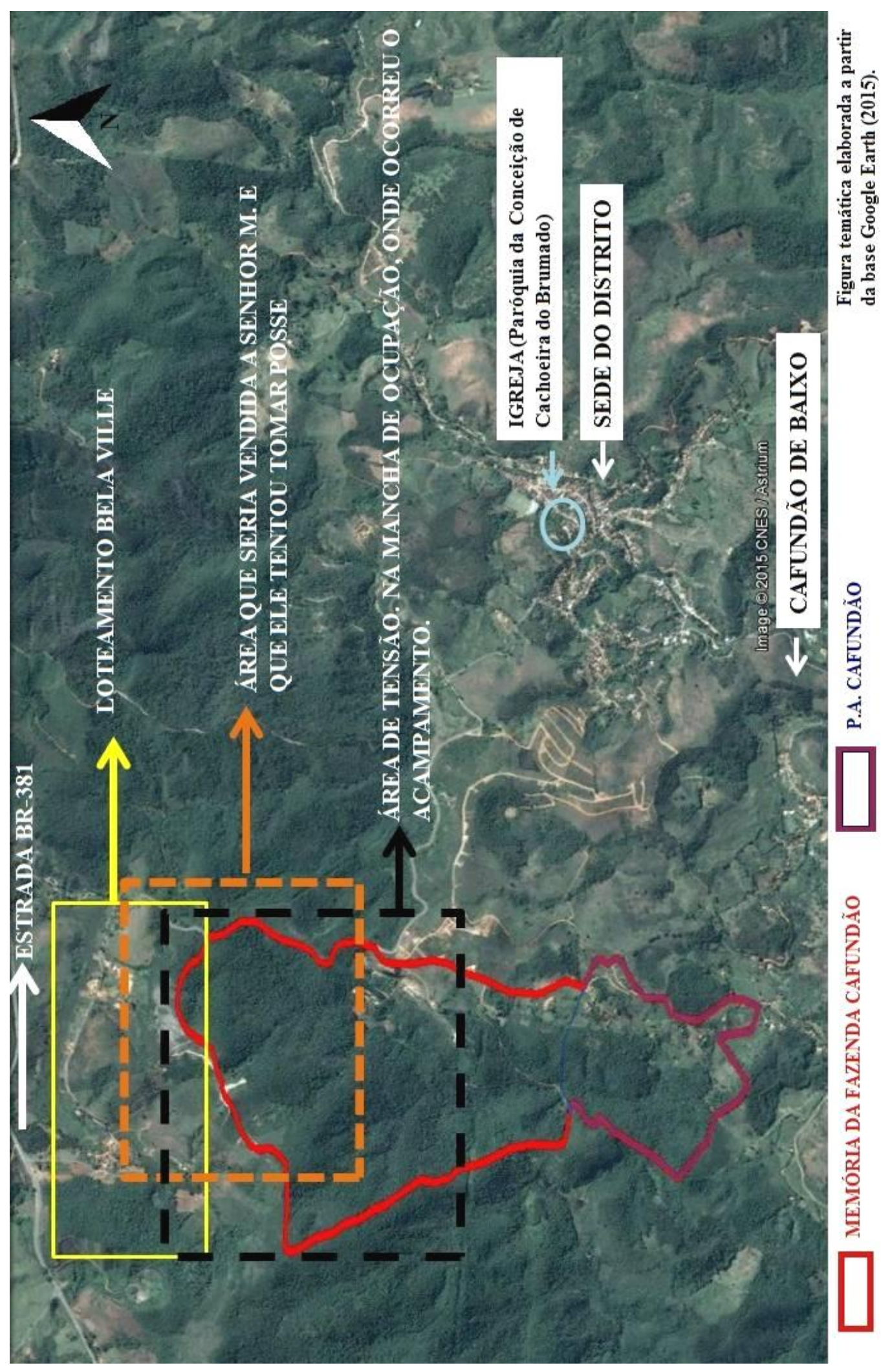


O histórico de ocupação do distrito marianense de Cachoeira do Brumado remonta, segundo Cônego Raimundo Trindade $(1945)^{63}$, a 1703 com a chegada do explorador de ouro João Pedroso. Posteriormente, João Lopes Pereira instala-se na localidade e inicia a construção da primeira capela. A partir deste momento, coabitam nestas terras exploradores de ouro, suas famílias, religiosos e escravos. A este respeito, segundo os dados do ano de1830 do programa de População nas Listas Nominativas de Minas Gerais - PopLin Minas ${ }^{64}$, da Universidade Federal de Minas Gerais, o distrito de Cachoeira do Brumado, pertencente ainda à Freguesia de Sumidouro, possuía 244 escravos, forros, e libertos. Esta lista baseava-se nos cálculos reunidos pela própria Freguesia, ou seja, pela Igreja, que contabilizou neste mesmo ano 596 escravos, forros e libertos em todo município de Mariana. Desta forma, o distrito de Cachoeira do Brumado concentrava cerca de $40 \%$ daqueles considerados à época de 1830 escravos e ex-escravos. À título de comparação, o município de Mariana, no ano de 1830, possuía cerca de 2949 habitantes, dentre os quais 53 pessoas eram sacerdotes.

Segundo Trindade (1945), em 1769 houve doação de terras, realizada por um padre através de testamento, para a construção daquela que viria a ser a Igreja Matriz de Nossa Senhora da Conceição de Cachoeira do Brumado. A este respeito, Paulo Vinícius Santana (2011) elucida que, em Mariana, os padres exerciam atividades para além do sacerdócio, na inserção de outras ligadas, principalmente, à agropecuária, mas também ao aluguel de casas, à comercialização em boticários, e até em empréstimos de dinheiro, numa espécie de transação bancária. Ou seja, comum tornou-se a posse de terras e casarios.

No parágrafo terceiro do artigo $8^{\circ}$ da Lei $n^{\circ} 271$, de 15 de abril de $1844^{65}$ fica instituído, a partir da capela, a criação do distrito, também chamado de Distrito de Paz, de Cachoeira do Brumado, que seria incorporado à Freguesia de São Caetano do Município de Mariana. Ou seja, a capela é um grande marco de povoamento, como demonstra Claudia Damasceno Fonseca (2012) acerca da urbanização de Mariana que se dá através destes núcleos de povoamento de clérigos, até a chegada da Câmara Municipal, em 1711, enquanto representativa do poder do Estado-Português. Segundo Trindade (1945), a elevação do distrito

\footnotetext{
${ }^{63}$ É preciso salientar que esta obra datilografada, do Cônego Raimundo Trindade (1945), não foi devidamente digitalizada no endereço que se acessou. No sítio apresentado nas referências, tem-se o acesso de todo o texto, mas não segue uma ordem de paginação.

${ }^{64}$ Desenvolvido no Centro de Desenvolvimento e Planejamento Territorial - CEDEPLAR - da Universidade Federal de Minas Gerais. Disponível em: https://ti.eng.ufmg.br/pop30/principal.php . Acesso em 21 de dezembro de 2014.

65 Disponível no sítio da Assembleia Legislativa, no endereço: http://www.almg.gov.br/consulte/legislaca o/completa/completa.html?tipo=Lei\&num=271\&comp=\&ano=1844.
} 
à freguesia só se dá em 1850, através da Lei Provincial nº 471 de 01 de junho. A preocupação deste Cônego Raimundo Trindade (1945) seria quando de fato as paróquias tornaram-se freguesias, numa ação da Instituição Canônica, ao invés de paróquias resultantes de padroados. Em outras palavras, a sua preocupação era reconhecer aquelas paróquias com confirmação episcopal, que distinguem de outras criadas sob acordos com o Estado-Português chamadas de padroados.

De resto, para o fato de que me venho ocupando, a saber, da criação de paróquias no Brasil-Império, pouco interessa a ação do Padroado; o que importa, diante do Direito Eclesiástico, é a Instituição Canónica ou confirmação episcopal do ato meramente civil da criação de uma freguesia. Dessa Instituição, que se processava nas Cúrias Episcopais, é que, em verdade, dependia a personalidade canónica das paróquias.

[...] Perderam-se, infelizmente, muitos processos de Instituições de igrejas. À data dessas instituições, sempre que possível, dou preferência, por ser a da verdadeira e legítima criação de uma freguesia. (TRINDADE, 1945, P. 65).

Acerca do mencionado padroado, Paulo Vinícius Santana (2011) elucida que ele é resultante da mencionada força complementar que se estabeleceu entre Igreja e Estado.

Os Ultramontanos, grupo do qual Dom Viçoso foi o maior expoente, atacou a intervenção estatal nos assuntos da Igreja Católica no Brasil, por meio do padroado régio, a Igreja Católica submetia-se ao Estado, um sistema que garantiu vantagens mútuas durante muito tempo. Permitiu que Portugal aproveitasse da estrutura Igreja para fomentar a colonização e administração das novas terras, além do poder de veto sobre as determinações papais. A Igreja, por sua vez, garantiu pra si o monopólio da religião oficial em todos os domínios portugueses e o custeio de suas atividades por meio do repasse do dízimo que era cobrado pelo Estado. (SANTANA, 2011, p. 33)

Nestes termos, é possível que o histórico de ocupação do distrito de Cachoeira do Brumado, e especificamente do Cafundão, remonte ao patrimônio da Paróquia desta localidade, ora por doação, ora por desenvolvimento de atividades de seus clérigos. O que poderia justificar uma possível ação legal, em seu sentido jurídico, de que esta Paróquia vendesse ao comprador senhor M. parte que lhe pertencia e que está escriturada na Certidão de Serviço Registral de Imóvel (COMARCA DE MARIANA, 1991), que se sobrepõe à cerca de metade das terras que são hoje assentamento. 
Porém, a suposta venda destas terras foi realizada com a posse pacífica e contínua de toda a família e ascendência do senhor Adão. Emerge, portanto, uma conflitualidade que nutre o debate de considerar este caso um impasse. Ao considerar a criação do Distrito de Cachoeira do Brumado segundo a mencionada Lei $\mathrm{n}^{\circ}$ 271, de 15 de abril de 1844, o histórico de ocupação de Joaquim Silvério de Oliveira, bisavô do senhor Adão, passa a ser considerado enquanto posseiro. Ou seja, ele passa a ser um lavrador que ocupa uma pequena área de terra, fazendo jus à sua função social de produzi-la, porém não possui um documento oficial que comprove sua posse, pois se trata de terras devolutas, que pertencem ao Estado. Na ordem deste processo, aquele que possui posse contínua é passível de regularização, desde que não haja escritura ou registro do imóvel.

O suposto registro do imóvel que seria vendido ao senhor M., datado de 1769 que é o ano das primeiras ocupações nesta localidade que viria a ser o distrito de Cachoeira do Brumado, só é ratificado pela Igreja em 1850, ano de elevação desta localidade à freguesia. Porém, em 1850 é possível que Joaquim Silvério já fosse vivo, e já morasse nesta localidade. Senhor Adão é nascido em 1939. Francisco da Cruz de Oliveira, seu pai, faleceu por volta do ano 1994, salvo diferença de poucos anos, com 106 anos de idade, conforme Termo de Audiência do Poder Judiciário de Minas Gerais (2004). Isto significa que pode ter nascido por volta do ano de 1888. Antes dele, havia a geração de João da Cruz de Oliveira, seu pai, e avô do senhor Adão - que ainda não surgiu no relato do senhor Adão, por motivos que se falará no próximo tópico -, e o próprio Joaquim Silvério de Oliveira, que pode ter supostamente ocupado esta área antes mesmo da elevação em freguesia. Ou seja, Joaquim Silvério poderia ser considerado posseiro, pois é anterior à própria freguesia, como forma oficial da Igreja de reconhecer seu domínio, para além do padronado. Isso nutre o sentimento do senhor Adão de querer que esteja reconhecido o seu direito a terra através da herança, o que se aproxima do que Margarida Maria Moura (1978) chama de Patrimônio Territorial, que é ser herdeiro ou possuir parentesco na terra. Ele afirma que se reconhece enquanto assentado, mas se sentiu injustiçado de quase perder a terra que nasceu para alguém que tinha mais dinheiro, tinha amigo na polícia, na política e até no cartório.

Desta forma, há o impasse de coabitar e de sobrepor os poderes da Igreja e do Estado, mas que foi solucionado na ratificação realizado pelo Estado, através da autarquia INCRA, de reconhecer a posse da Igreja mediante contrato de compra e venda do imóvel rural para fins de reforma agrária. Aliás, o Estado realizou o pagamento à Igreja de cerca de quarenta e duas 
(42) vezes superior ao valor acordado com o senhor M., sendo necessário realizar os ajustes inflacionais necessários. Contudo, o senhor Adão não deseja retomar esta história para que um possível ajustamento seja feito. Ele é assentado, diz por vezes. O que deseja é somente que se saiba que não se lutou em vão. O senhor Adão apresentou um desejo maior de registrar esta história como exemplo para outros. O que o motiva estar aqui hoje dando essa entrevista? Por que alguém às vezes acha que tudo acabou... Se não acabou, ainda tem um recurso. A gente ainda pode pegar e dar uma animação para alguém que não tem, para outra que tá na mesma situação, afirma o senhor Adão.

Ser assentado é hoje sua força, força contra gente que não tem nada a vê. Gente não herdeiro da terra. Em relação ao senhor M., o senhor Adão diz sentir uma injustiça em relação a ele ter saído impune de tudo que fez, e nem ser ligado a terra, pois ele até largou a terra e sumiu no mundo, ninguém sabe onde tá. Optou-se não explicar para ele que o senhor M. ainda está vivo, e mora no litoral sul da Bahia. Percebeu-se que isso acentuaria a sensação de impunidade, algo que não poderia ser reconvertido por esta pesquisa, em seu sentido ético. A relação entre ética e pesquisa é trabalhado por diversos autores, dentre o qual destaca-se Paollo Nosella (2008) para quem a ética institui um limite da responsabilidade por aquilo que se constrói nos terrenos da sociabilidade.

\subsection{O acampar como forma de fazer-se visto.}

Como proposta de resolução deste impasse, o que o senhor Adão chama de "recurso", foi a criação do Projeto de Assentamento Cafundão em âmbito federal. A Câmara Municipal de Mariana inseriu-se neste conflito no viés de amenizar a luta armada que já deixara duas pessoas feridas, além do dano psicológico. Criou uma Comissão Parlamentar de Inquérito, que acompanhou o desdobramento do processo, mas o relatório resultante não se encontrava na Câmara arquivado. A Assembleia Legislativa de Minas criou uma Comissão Especial em 1992, também sem relatório resultante ${ }^{66}$. O Sindicado dos Trabalhadores Rurais desta cidade é o que menos fez, conforme aponta o senhor Adão. O Sindicato METABASE é o grande nome referenciado nesta história, por instruí-los, acompanha-los, articula-los com

\footnotetext{
${ }^{66}$ Disponível no sítio da Assembleia Legislativa, no endereço: http://www.almg.gov.br/consulte/legislac ao/completa/completa.html?tipo=Lei\&num=271\&comp=\&ano=1844.
} 
outros nomes, além de realizar a defesa jurídica por meio da concessão de serviços de advocacia.

A Prefeitura de Mariana menciona em reportagem a pretensão em resguardar os habitantes do local, e encaminha pedido de desapropriação até pensar numa medida nova. O resultado disso foi a inserção da polícia para promover à desapropriação, de fato. $\mathrm{Na}$ memória, isso ficou como estando a favor daquele terceiro, senhor M., que beneficiado seria com o fato de que os habitantes haveriam de sair. Não saíram: resistiram. Já o Delegado de Polícia, conforme mencionado, fora afastado das funções por omissão, e por contribuir no tumulto do caso do Cafundão.

A criação do assentamento revela-se como resolução primordial a este conflito, dado o patamar federal em que foi empreendida. Percebe-se que a nível local e até estadual, a tensão pela terra do Cafundão estava sendo encarada enquanto impasse. Foram criados artifícios formais de discussão do que se faria e relatórios finais não foram expeditos. Faltavam conclusões sobre como proceder neste caso, que envolvia além da posse jurídica da Igreja, outros elementos ligados às oligarquias rurais. Fala-se de, por diversas vezes, haver menção nas entrevistas que as terras que circundam o assentamento pertencem à família do ex-prefeito da cidade, João Ramos Filho, reconhecidamente donos de grandes terras, sobretudo neste distrito. E, também por isso, seu opositor político adentra as tensões por esta terra expedindo pedido de desapropriação. O Cafundão estaria imerso, portanto, na invisibilidade concernente a históricos conflitos fundiários entre grandes detentores de terra, com relações amistosas com políticos, e os posseiros e ocupantes do local, o que torna esta tensão também um aspecto político. Aliás, acerca desta invisibilidade, questionou-se como percebem que são tratados e recebidos no local, enquanto assentados de reforma agrária.

Tratam igual. Assim, nem sabem que é assentamento e perguntam se tem assentamento lá. Nós temos que falar assentamento Cafundão. Por que até a conta de luz vinha errado, vinha Cafundão, vila Cafundão. Aí explica, esse é o assentamento Cafundão. Mas tem essa separação por que lá em cima não é assentamento e lá embaixo também não é assentamento... Até uma parte desse morro descendo é o assentamento, mas ai depois já não é mais. [O Cafundão de Baixo é conhecido como Vargem Alegre, não é?] É, mas lá esse Vargem Alegre não foi aprovado pela prefeitura. Não aprovou por que o povo já conhece como Cafundão (Fala da Dona Sandra) 
A transformação em assentamento adquire significâncias atreladas, portanto, ao fazerse visto destes que se tornaram assentados. Antes, o movimento que incita visibilidade se mostrava inerente à resistência na terra, ainda que suas vidas estivessem de fato ameaçadas, e ao acampar sob lona, que converge enquanto ferramenta de pressão social pela terra. O tornarse assentado agregou legitimidade à reprodução na terra destas famílias. Por se tratar de um assentamento implantado nas terras onde os beneficiários sempre viveram, contribui para que o Cafundão se difunda no imaginário marianense enquanto um bairro pertencente ao distrito de Cachoeira do Brumado (RÚBIO, 2012), e não como assentamento.

A conquista da visibilidade é, deste modo, realizada através daquilo que se tornou cartão de visitas, que é ser assentado de reforma agrária. A visibilidade se expressa também a partir dos ônibus escolares que chegam ao local com universitários e demais visitantes que vão em busca do produto artesanal produzido em um assentamento.

Porquanto, o cenário nas terras do Cafundão era, portanto, de tensão. A desapropriação destas terras foi requisitada pela Prefeitura e, para concretizar, o senhor M. aparado por força policial manda queimar as casas que lá se encontravam. Só restou a memória da casa do Francisco da Cruz de Oliveira, que o senhor Adão aponta, diz ter sido lá criado, mas somente se vê árvores e gramas sem muitos resquícios de construção ou destruição.

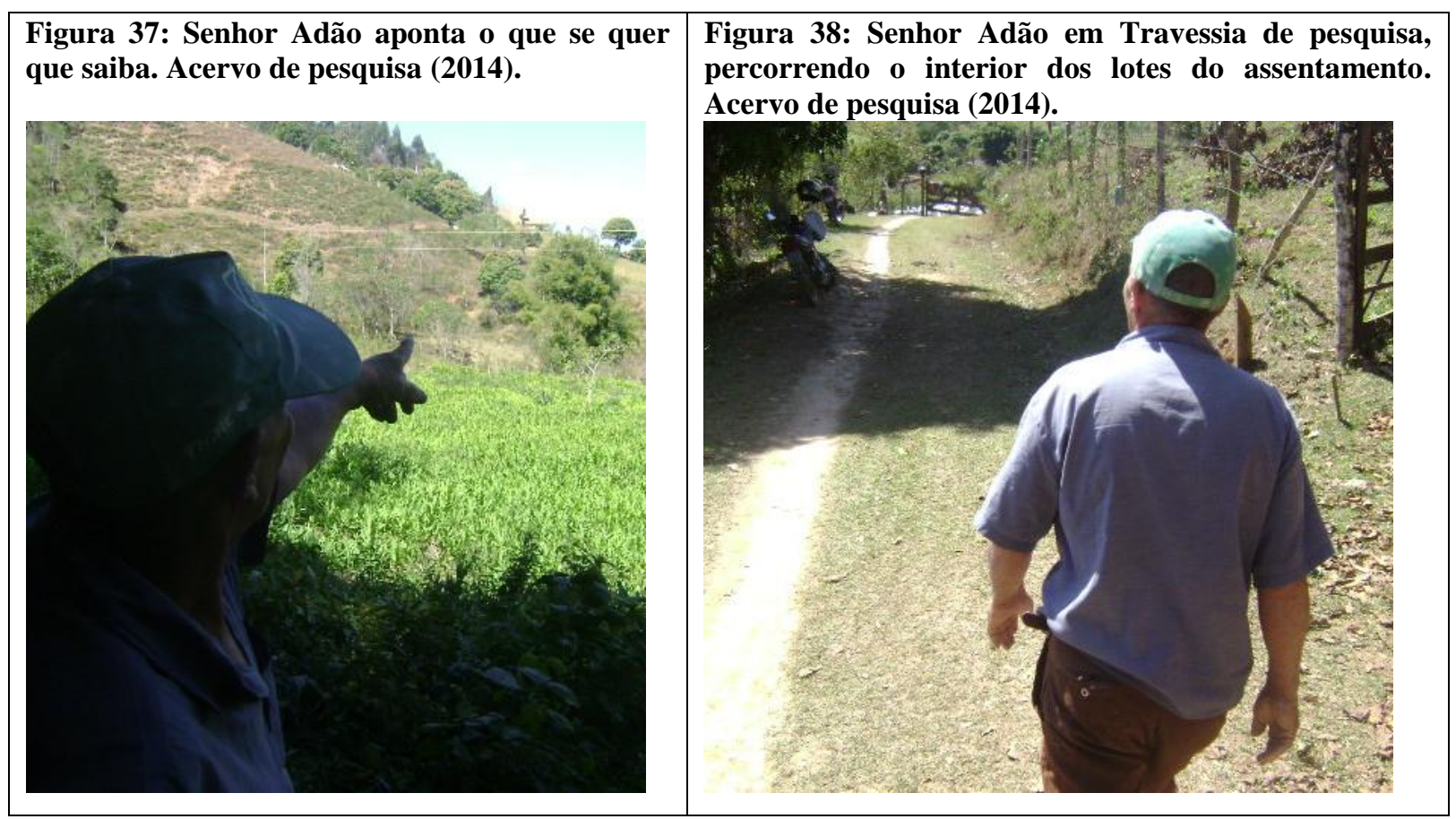


Figura 39: Senhor Adão aponta onde se localizava a casa de seu pai, Francisco da Cruz de Oliveira, em área próxima ao córrego da Pinduca, onde ainda existe o moinho d'água conforme Figura 17. Acervo de pesquisa (2014).

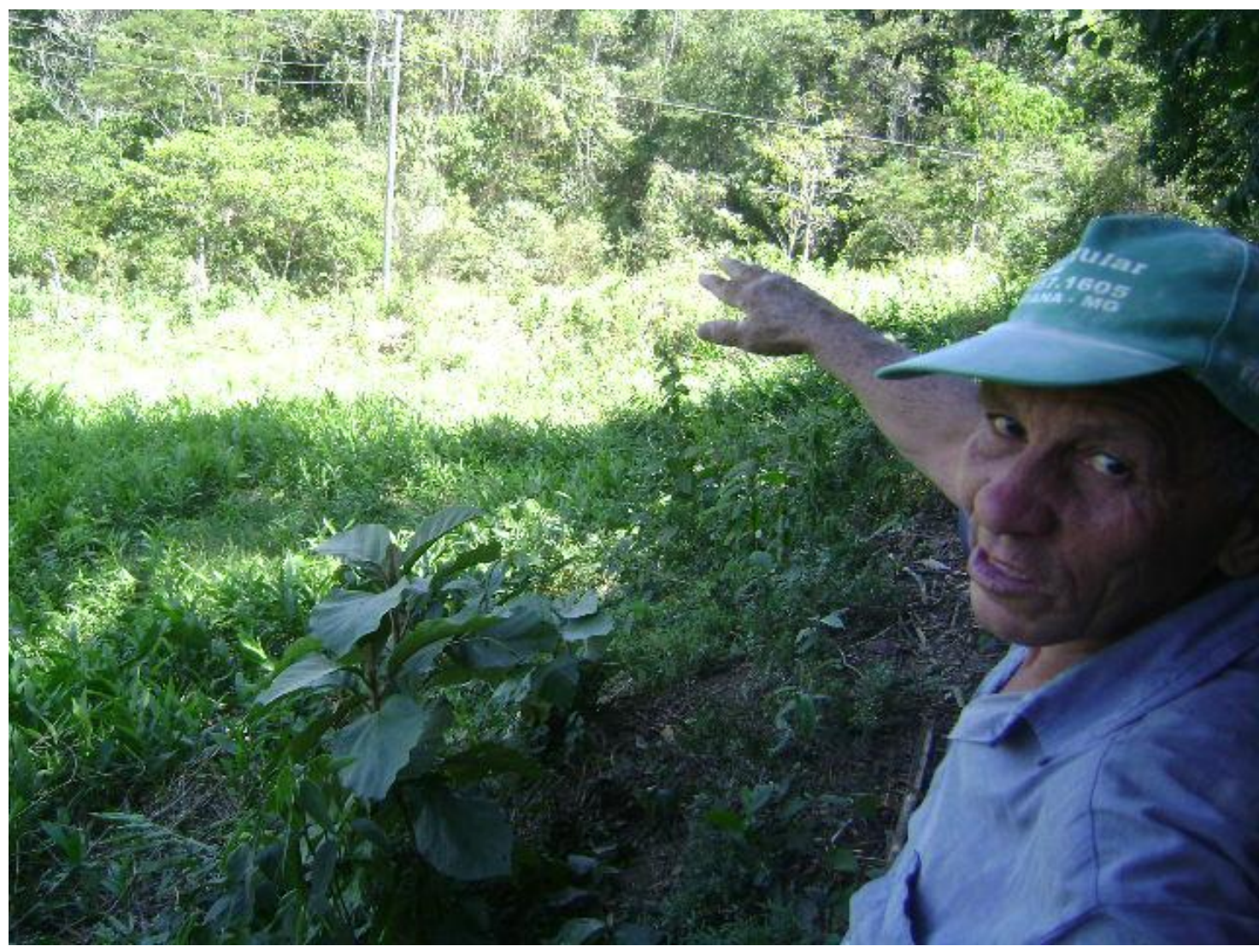

Figura 40: Senhor Adão reforçando que ele se orienta através da cerca. Percebeu-se que se tratar de onde ela está ou esteve um dia. Acervo de pesquisa (2014).

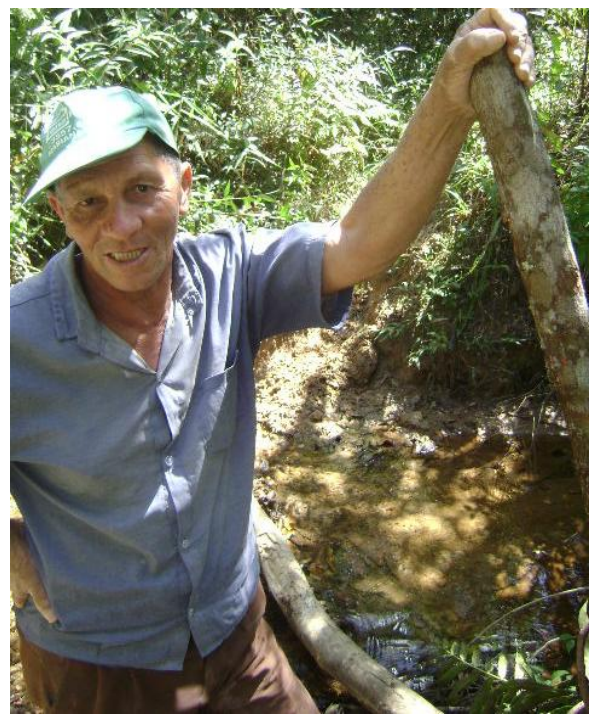

Figura 41: Senhor Adão abrindo-se à pesquisa. Acervo de pesquisa (2014).

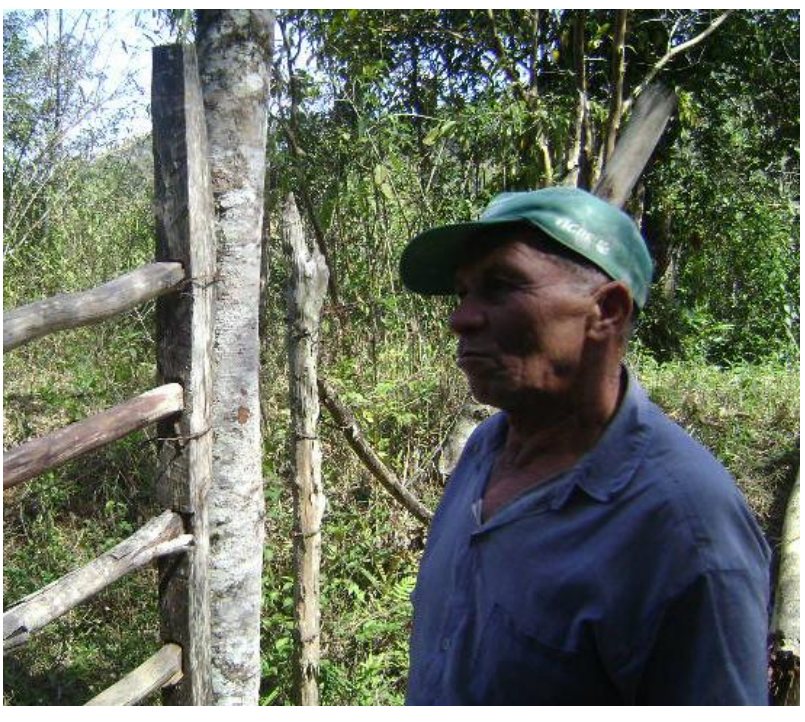


Já o processo jurídico mencionado no capítulo 01, de número 001620287.1997.8.13.0400, que consta no Tribunal de Justiça de Minas Gerais de forma interrompida, diz respeito à indenização que o senhor $\mathrm{M}$. teria que pagar àqueles que tiveram suas casas derrubadas e queimadas ao seu mando. Tal processo só se desenvolveu em 2004, segundo o Termo de Audiência do Poder Judiciário do Estado de Minas Gerais (2004). Neste Termo de Audiência fica decidido que o imóvel construído pelo senhor M., em suas terras que divisariam com aquelas herdadas pelo senhor Adão, não poderia ser penhorado a título de pagamento de indenização, por se tratar de moradia única e, portanto, outro imóvel deveria ser encontrado. O processo fora interrompido. E, para o Adão, o senhor M. sumiu no mundo, a despeito de se ter feito contato - não correspondido - por e-mail, e de se ter verificado que ele atua normalmente em sua profissão e outro empreendimento numa cidade no litoral sul do Estado da Bahia.

Contudo, o intervalo entre tais conflitos referenciados pelo $O$ Monumento (1990) e a vistoria do INCRA (DOU, 1992) é de dois anos. Ao longo desses dois anos, a Ata da Câmara Municipal de Mariana, em seu Livro 10 que dispõe sobre o período de 30 de novembro de 1989 a 17 de agosto de 1992, registra que os moradores locais permanecem pacíficos, dado a importância de assim confirmar a legitimidade do seu direito a terra. Foram dois anos num misto de resistência, violência, esperança e luta.

A importância do Sindicato METABASE nasce na articulação com outras vozes para que dialoguem com os nascidos do Cafundão. O senhor Adão menciona um momento que para ele seria crucial e definitivo, onde se fosse pra morrer, a gente morreria lá mesmo. Trata-se da decisão de montar um acampamento sob lona nas divisas das terras, ou seja, entre a parte que o senhor M. já havia tomado posse e construído sua casa, ao topo da vertente, e a parte que o senhor Adão acreditava que seria sua por direito, e por herança. Ao invés de continuar fugindo, eles foram na direção daquele que os ameaçava. Indagado sobre quem tivera essa ideia do acampamento, o senhor Adão menciona o Sindicato METABASE.

Este Sindicato contribuiu na mobilização de suprimentos para que os homens permanecessem acampados, enquanto que as mulheres e os filhos se ajudavam no restante das casas não queimadas. Articulou-se com outro Sindicado de Trabalhadores de Ouro Preto ASSUFOP, para doação de alimentos. Financiou a ida de vários homens, inclusive o senhor Adão, ao escritório do INCRA-MG, na capital do Estado. Se não fosse a pirua [automóvel do tipo Kombi], nós não tinha condição de ir, ressalta senhor Adão. É... Não tinha mesmo, não 
tinha nem pra comer direito. Vinha comida em caixa pra nós, concorda senhor Nilton. Nesta ocasião, apareceu também no Cafundão membros do MST que ofereceu apoio e os acompanhou na viagem ao INCRA.

Para o senhor Adão, o acampar a poucos metros de onde vivia o senhor M. era uma forma de afrontá-lo, de dizer que agora não mais fugiriam, que se fosse o caso morreriam ainda dentro de suas terras. Para o desenrolar do conflito, o acampar significou um instrumento político, uma reunião de voz a ser ouvida, um fazer-se ser visto. Ir ao INCRA, para o Adão, significou uma maneira institucionalizada de reconhecer o seu direito a viver onde nasceu. Esta maneira se traduz na criação do assentamento de reforma agrária. Ele não questiona, mesmo que instigado, o fato de hoje possuir apenas o seu lote dentro do assentamento. Por que não tem mais o negócio de brigar. Agora tenho minha parte, meus filhos vivem e constroem dentro da minha parte. E ninguém mexe com a parte do outro.

A este respeito, Lidiane Silveira et al (2009), em estudo acerca da ocupação de terras em regime de parceria em Piumhi, no sudoeste de Minas Gerais, constata que a terra adquire significâncias que se relaciona ao trabalho, em seu sentido amplo. Estas terras, consideradas pântano, foram resultantes da transposição do rio Piumhi para a construção da Hidrelétrica de Furnas. O histórico de ocupação, segundo Silveira et al (2009), se relaciona aos vínculos que os ocupantes possuem com a terra por meio do trabalho que legitima, até 1950, a sua posse. A partir deste momento, estes autores ressaltam que predomina o regime de acampamento enquanto pressão social e legitimidade ao acesso a terra, conforme enfoca Sigaud (2005) na construção da sociogênese dos plantadores de cana de Pernambuco.

Contudo, percebeu-se que a ideia de herança nutre o vínculo com a terra grandemente respaldado a partir do trabalho com a pedra, que nesta terra aflora. $\mathrm{O}$ fazer-panela emerge enquanto justificativa de legitimidade conjuntamente ao ser herdeiro de Joaquim Silvério e Francisco de Oliveira. Também por isso, e por que as terras do assentamento de certa forma impedem o seu amplo cultivo, por que os lotes são relativamente pequenos e ainda estão localizadas em áreas extremamente íngremes; o cultivo da terra não é tão salientado. Produzir a terra, no caso do Cafundão, se preenche de significado a partir do trabalho na Cooperativa, algo diferenciado ao trabalho agropecuário observado por Silveira et al (2009) e a forma de acampamento salientado por Sigaud (2005).

Contudo, o estudo de Maria Cecília Turatti (1999) destaca as significações do acampamento, enquanto etapa fundamental da operacionalização da luta pela terra, e 
instrumento característico do MST. Além disso, esta autora enfatiza a necessidade de se estudar o acampamento sob lona enquanto organização social, pois "é o momento-chave da passagem para a condição ser sem-terra, para um estilo de vida coletivo que engendra solidariedade e conflito ao mesmo tempo" (TURATTI, 1999, p. 04). Esta organização social é marcada por uma condição que é a da transitoriedade, da mudança, da luta por algo que não se sabe ao certo quando se conquistará e se conquistará. Por ser trânsito, o retorno à vida anterior é dificultada a ponto de esta autora admitir que exista uma certa dependência dos acampados em relação aos dirigentes e organizadores do movimento MST.

Esta quase 'inevitabilidade' denota uma frágil identidade de pertencimento grupal, que resvala para o desejo de fuga do movimento logo após a conquista da terra. O sacrifício em ficar acampado aparece, então, como uma via sem nenhum componente ideológico. Suportar as condições penosas de vida e a obediência às regras que foram estabelecidas extragrupalmente fazse, ao mesmo tempo, necessário e odioso. Para o projeto produtivo do MST, esta sociabilidade forçada nos acampamentos surge como um grande entrave. A proposta de trabalhar coletivamente a terra passa a ser inaceitável para pessoas que aprenderam, durante meses, a não confiar umas nas outras. De fato, torna-se deveras complexo estabelecer laços cordiais de barriga vazia. Em uma situação em que não houvesse tanta morosidade em realizar os assentamentos, provavelmente o estabelecimento de uma sociabilidade sob bases materiais razoáveis se faria de maneira mais solidária (TURATTI, 1999, p. 27).

Neste sentido, Turatti (1999) elucida que a característica marcante dos acampamentos é a vida social que se dá sem vínculos pregressos de memória, tradição e sociabilidade, o que coloca a condição da transitoriedade com uma riqueza de análise, mas também como paradoxo do movimento, que se enfraquece após a conquista da terra.

Por carregar esta condição de transitoriedade, lançado na indefinição, o acampamento apresenta características muito peculiares de estabelecimento e existência. A flexibilidade de ocupação de espaços territoriais, a convivência de pessoas que não compartilham nenhum vínculo pregresso de memória, tradição ou sociabilidade, o ócio apenas rompido pelas tarefas cumpridas na organização do acampamento ou na realização de tarefas domésticas básicas, são algumas das situações inscritas na realidade de um acampamento e que, sem dúvida, concedem-lhe uma atipicidade frente às formações sociais tradicionais do meio rural brasileiro (TURATTI, 1999, p. $05)$. 
O que se rearranja de forma diferenciada no caso do Cafundão, em que vínculos familiares, que ratifica laços pregressos de memória, nutrem a resistência na terra e a luta por ela, pautada no sentido e sentimento de herança e, ainda, garante a reprodução deste grupo social nas terras do Cafundão sob vínculos familiares.

Contudo, alguns assentamentos mineiros passaram pela etapa do acampamento amplamente apoiado pelo MST e por sindicatos de trabalhadores rurais. O número da reforma agrária em Minas Gerais, segundo dados do INCRA (2014), é de 310 projetos criados, com 15.974 beneficiários. A grande maioria destes projetos foram implementados na região norte, centro-norte, e na zona da mata leste do Estado, conforme pode ser percebido no mapa abaixo. Percebeu-se que muitos destes localizam-se em municípios vizinhos uns aos outros, agrupam-se, a concretização de um torna a força de criação para outro.

Mapa 4: Localização dos Projetos de Assentamento no estado de Minas Gerais, segundo INCRA (2014).

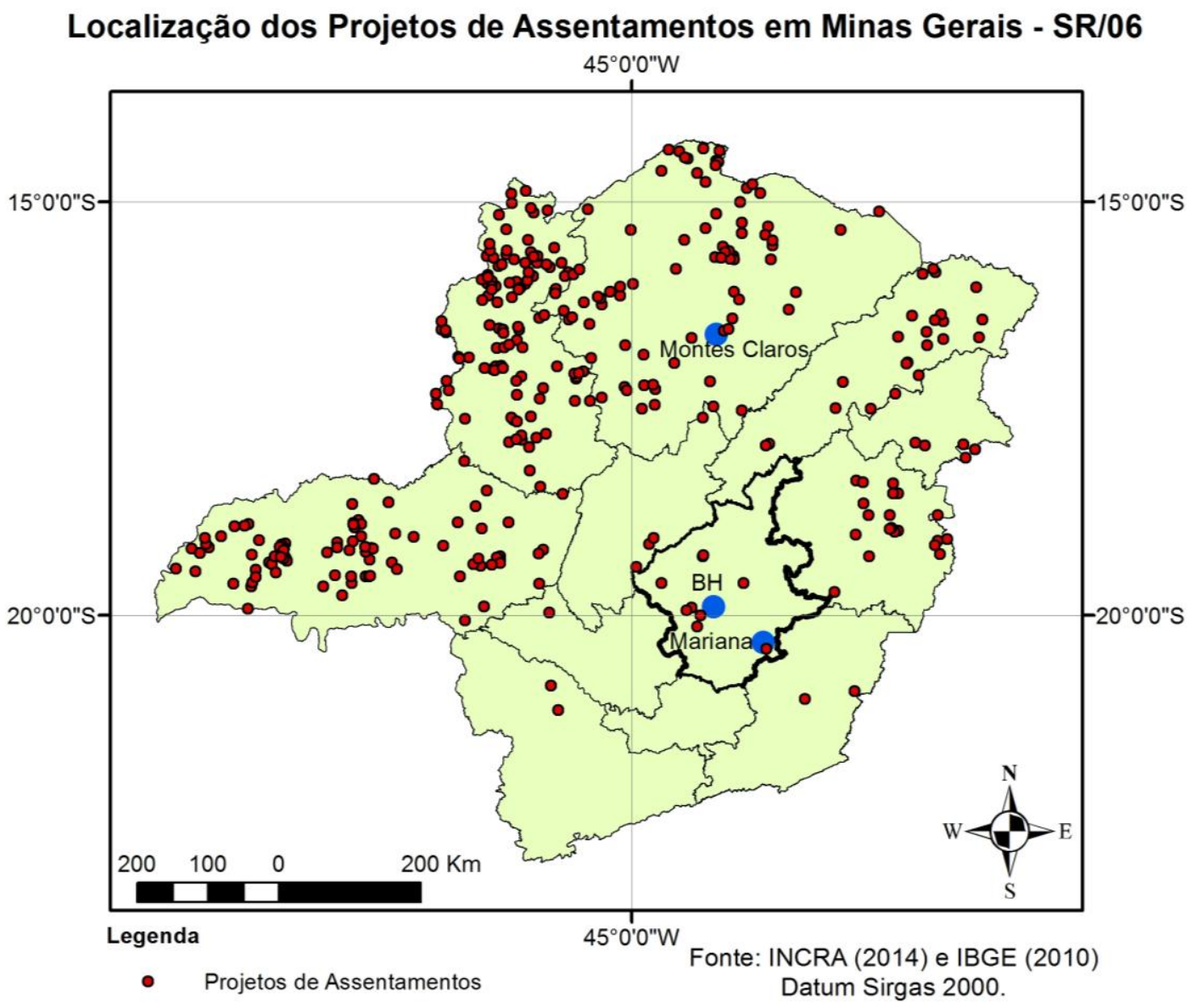


Contudo, os projetos de assentamentos que foram criados mais próximos ao município de Mariana se localizam a pelos menos $150 \mathrm{~km}$ de distância, quais sejam: Betim (a $136 \mathrm{~km})$, Nova União (a $118 \mathrm{~km}$ ) e Brumadinho (a $125 \mathrm{~km}$ ), localizados na Grande Região Metropolitana de Belo Horizonte, e Visconde do Rio Branco (a $156 \mathrm{~km}$ ) na zona da mata mineira. Todos estes projetos foram criados a partir de 1997, ou seja, dois anos depois da criação do assentamento Cafundão. Segundo Carlos Eduardo Mazzeto Silva (2008), o histórico de criação destes assentamentos está relacionado à articulação política com sindicatos de trabalhadores rurais e com a Federação dos Trabalhadores na Agricultura do Estado de Minas Gerais - FETAEMG. Somente um deles, o assentamento Ho Chi Min em Nova União esteve completamente articulado com o MST, inclusive adotando a fase do acampamento. Segundo Silva (2008), esta ocupação contribuiu para disseminar outras na mesma região, porém somente o Ho Chi Min obteve status de Projeto de Assentamento e se encontra agora em vias de consolidação.

Percebe-se, portanto, a importância da fase do acampamento na luta pela terra. A transitoriedade de uma vida sob lona traduz uma inconsistência acerca de quando obterão à infraestrutura necessária à construção de suas histórias na e a partir da terra. Contudo, o acampar dos assentados do Cafundão, a despeito de ser empreendido também a partir de articulação política, carrega o signo de reconstituição da memória da terra, da luta pela herança, pelo direito, pela vida. É uma luta de uma família, que incorporou novos membros, à construção do ser-assentado. E é sobre isso que irá se debruçar.

\subsection{As significâncias do ser-assentado e o fazer-panela na terra}

O mapa do assentamento ${ }^{67}$ realizado pelo INCRA em 1994, logo abaixo, fornece elementos cruciais ao entendimento da tensão relacionada à criação, de fato, do assentamento tendo em vista o histórico de ocupação da família do senhor Adão nestas terras. É possível constatar os dozes nomes daqueles que seriam assentados, sem os seus respectivos cônjuges, e a dimensão do lote que seria de cada um destes.

\footnotetext{
${ }^{67}$ Este mapa foi acessado no escritório local da EMATER, em Mariana, e como documento oficial, emprestou-se por alguns minutos para que se xerocasse e, posteriormente, fizesse a digitalização. Também por isso necessitouse que uma nova versão fosse construída tendo com base o pacote de dados oficial acerca do assentamento, as coordenadas neste mapa presente, e a demarcação aproximada dos lotes.
} 
Mapa 5: Mapa dos lotes do Projeto de Assentamento Cafundão, elaborado pelo INCRA (1994). Digitalização realizada pela autora, que verificou, a partir das coordenadas deste mapa, a sua correspondência com os dados do INCRA (2010).

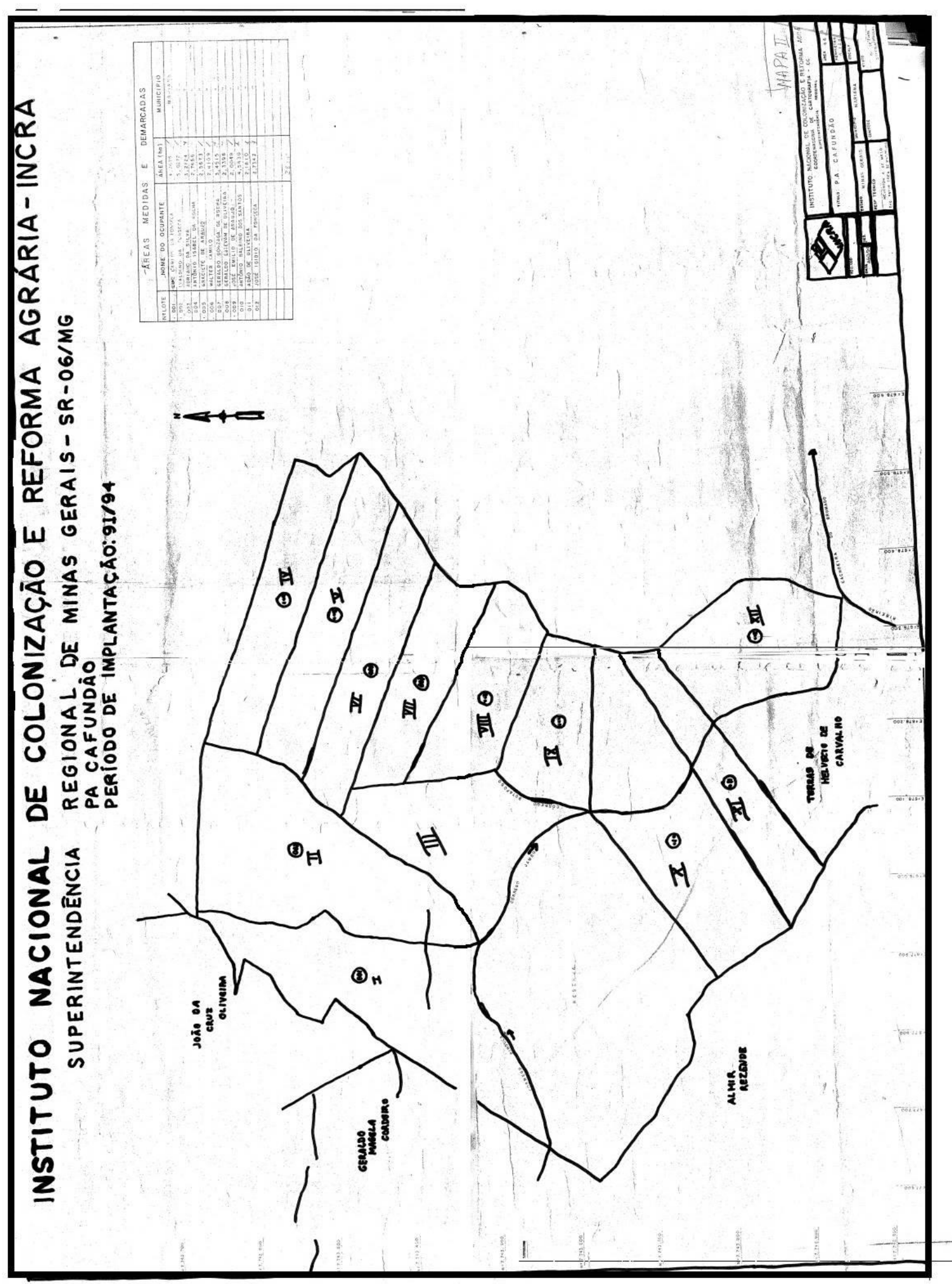


O maior lote é de aproximadamente cinco (5) hectares, mas se localiza em área acentuadamente declivosa. O menor lote possui dois (2) hectares em área de colúvio, na parte inferior da vertente. Por isso, trata-se de lote mais aplainado e de melhor aproveitamento. Ao somar o tamanho de todos os lotes, chega-se em 38,0051 hectares, o que significa que há uma área de 10,4059 hectares que correspondem à reserva, ou área de proteção ambiental. A maioria dos lotes possui o tamanho entre 2,5 e 3,5 hectares, e neste mapa não constam ainda aquelas frações de terra consideradas de uso comum, como áreas de passagem geralmente construídas perto das cercas, o local onde foi construído a Cooperativa e onde se guarda os blocos de pedra, bem como o novo galpão ainda sem telhado, janelas, mas com sonho futuro de que será acabado e de uso comum para festas, reuniões e decisões.

Tabela 5: Reprodução ampliada da tabela contida no mapa anterior (INCRA, 1994). Optou-se pela manutenção dos nomes por estes já estarem contidos em documentos públicos acerca da reforma agrária, tal como o SIPRA.

\begin{tabular}{|c|l|c|c|}
\hline \multicolumn{5}{|c|}{ ÁREAS MEDIDAS E DEMARCADAS } \\
\hline N $^{\mathbf{0}}$ LOTE & \multicolumn{1}{|c|}{ NOME DO OCUPANTE } & ÁREA (ha) & MUNICÍPIO \\
\hline 001 & LUIZ CARLOS DA FONSECA & 4,7675 & MARIANA \\
\hline 002 & IVALDINO DA FONSECA & 5,0272 & \\
\hline 003 & ADRIANO DA SILVA & 3,2124 & \\
\hline 004 & ANTÔNIO ISABEL DA ROCHA & \\
\hline 005 & GRACIETE DE ARAÚJO & 2,7656 & \\
\hline 006 & WALTER CAMILO & 2,5673 & \\
\hline 007 & GERALDO GONZAGA DA ROCHA & 3,4515 & \\
\hline 008 & GERALDO ESTEVAM DE OLIVEIRA & 2,3396 & \\
\hline 009 & JOSÉ EMÍLIO DE ARAÚJO & ' \\
\hline 010 & ANTÔNIO BALBINO DOS SANTOS & 4,5430 & \\
\hline 011 & ADÃO DE OLIVEIRA & 2,1810 & \\
\hline 012 & JOSÉ EGÍIIO DA FONSECA & 2,7342 & \\
\hline
\end{tabular}

Neste mapa, com a lista dos que seriam assentados, consta o nome de uma senhora, que era cunhada do senhor Adão, mas que ele ratifica sempre não ter sido efetivamente casada. Percebeu-se o uso do termo "amasiada" ou "amigada", que se refere a aspecto 
pejorativo de subalternidade em relação a um casamento realizado com assinatura de documentos jurídicos e/ou cerimônia religiosa. Cabe salientar que este aspecto adentra o que Adriana Maluf (2010) denomina enquanto novas modalidades de família na pós-modernidade. $\mathrm{O}$ aspecto jurídico deste reconhecimento contribuiu ao atraso na aceitação social de famílias constituídas de forma diferenciada do que se institui através do casamento jurídico e religioso entre homem e mulher. O que Maluf (2010) designa enquanto evolução constitucional diria respeito ao avanço social à aceitação da pluralidade societária, que amplia as possibilidades de criação e realização de identidades valorativamente individuais, plurais, múltiplas. Tais relações são defendidas enquanto pautadas no afeto, ao invés de outras formas em que o coletivo se impõe à liberdade individual transfigurada em aspectos morais, raciais e discriminais.

Porquanto, a cunhada do senhor Adão, para não citar nomes já que ela não se encontra mais morando em tais terras, mudou de cidade, e não a encontrou para fins de entrevista nesta pesquisa; já não mais aparece enquanto assentada no SIPRA (2011) e SIPRA (2014). Isto pode ser explicado através do Termo de Audiência do Poder Judiciário de Minas Gerais (2004), no qual consta que ela requere o usucapião de terras, sendo contestada pelo senhor Adão e outros dois assentados. Neste Termo de Audiência, há a menção de que o senhor Adão, sua cunhada e os outros dois requerentes (que também possuem parentesco) decidem desistir da ação para fins de partilha da terra requisitada por usucapião, dado o histórico de ocupação e uso de todos eles, e por decidir interromper neste momento uma briga por terras que seria também uma tensão no interior da família.

A terra requerida diz respeito àquela em que no mapa do INCRA (1994) está com o nome de João da Cruz de Oliveira, que ao longo da pesquisa não fora sequer mencionado, inclusive pelo seu filho Adão. A ocultação do nome de João, que seria pai do senhor Adão e filho do Francisco da Cruz de Oliveira, se relaciona a própria briga judicial pelo pertencimento desta pequena gleba. Neste mapa, vê-se que a terra sob o título de João da Cruz de Oliveira, à esquerda do mapa, não fora mencionada no processo de criação do assentamento desenvolvido entre os anos de 1992 e 1995. João possuía posse desta terra, e os seus descendentes compartilhavam o uso através, principalmente, do plantio de milho. Tais descendentes seriam o senhor Adão, a sua cunhada representando seu irmão que falecera, além de seus dois outros sobrinhos que requisitavam a herança de seus pais - que também eram irmãos do senhor Adão. 
No Termo de Audiência (2004), a cunhada do senhor Adão decide pelo pedido de usucapienda de toda esta terra, a despeito das demais ocupações. Suspeita-se que houve o julgamento de que, se os demais já seriam em 2004 assentados de reforma agrária, em terras que correspondem ao terço médio da vertente, ela conseguiria sozinha a posse por usucapião das terras requeridas, localizadas de forma fronteiriça, mais ao topo da vertente. Decidiu-se neste Termo de Audiência (2004), no entanto, pela partilha entre todos os descendentes de João da Cruz de Oliveira. O desenrolar desta tensão ainda produz imaginários acerca de ser legítima ou não a posse da cunhada do Adão, ainda que compartilhada, em terras que foram de seu pai. Faz-se diversas vezes menção ao fato dela querer sozinha tudo. E nem era esposa, era amasiada, tenta defender o senhor Adão. Todavia, o Termo de Audiência (2004) reconhece o morar junto enquanto relação matrimonial, garantindo para a cunhada do senhor Adão o que lhe é de direito e que hoje está sendo cuidado pelo seu filho, que o senhor Adão ainda não menciona se tratar de seu sobrinho.

Desperta-se para o fato das múltiplas significações inerentes ao ser-assentado. Para aqueles diretamente envolvidos no processo de luta pela terra havia invocações que se tangenciam a ideia de herança (MOURA, 1978), ao lugar de vida e morada, onde se foi criado, uma luta por uma terra onde se viveu. Esta vida na terra estar-se-ia diretamente relacionada ao fazer-panela que emerge enquanto trabalho na relação íntima com a terra (SILVEIRA et al, 2009). O fazer-panela, com a pedra que ali ou acolá se retira, é um vínculo, é uma territorialidade de memória, de vida, e traduz uma identidade coletiva. O espaço-tempo do fazer-panela será atrelado nas conclusões, num nível teórico, para que se perceba a importância da cerca enquanto marco de memória.

Contudo, para outros, o ser-assentado significou a oportunidade institucionalizada de acesso a terra. É o caso, por exemplo, de um dos vizinhos do senhor Adão que possuía suas terras que também eram ameaçadas por terceiros, e se inseriu na lista de beneficiário como via de garantir a vida na sua própria terra. Como foi o caso de um outro senhor que trabalhava há anos com a família do senhor Adão em regime de parceria, seja na terra, seja no compartilhamento dos antigos tornos usados por eles. $\mathrm{O}$ ser-assentado lhe garantiu possuir $\mathrm{o}$ seu próprio lote no interior daquele que antes a posse não lhe pertencia, pois era da família do senhor Adão. De parceiro ele passa a ser assentado, convivendo conjuntamente aos onze demais beneficiários, além da oportunidade de comprar o seu lote, com prazo de pagamento, e reconhecimento federal de que elas agora lhe pertenciam. 
Não se pretende emergir o ser-assentado enquanto pressuposto que limita ou circunda um coletivo enfocado. Ou seja, não há aqui a proposta de limitar o que haveria de serassentado numa espécie de empacotamento de memórias, de identidades e do contexto social de requerer uma gleba. Tem-se enquanto signo que expressa relações as mais diversas com as terras do Cafundão. Ser-assentado expressar-se-ia numa espécie de territorialidade, no sentido de ser apropriado, ser simbólico, carregar marcas do vivido e do dominado, conforme se trabalhará no último e quarto capítulo.

O ser-assentado, desta forma, é mais uma fronteira que une as pessoas que vivem no assentamento. Tiveram que juntos operacionalizar a divisão dos próprios lotes, as áreas de passagem, o que haveria de ser coletivo. A vida no assentamento significou escolher coletivamente que o PDA - Plano de Desenvolvimento do Assentamento - do Cafundão se norteasse pela criação de uma Cooperativa de Pedra Sabão, ao contrário de outras ações ligadas a atividades agropastoreiras. A Cooperativa emerge enquanto signo coletivo do trabalho em terras do Cafundão, estando inclusas as tarefas de terem que compartilhar água, energia, os tornos estão aí, e aqui não pode ter nenhuma briga, elenca o senhor Adão.

Esta Cooperativa expressa uma relação diferenciada que tais assentados possuem com estas terras, especificamente. Trata-se de área de afloramento da rocha esteatito, o que aumenta a importância da compra e venda realizada pelo INCRA dessas terras e não de outras, para fins de reforma agrária. Como já mencionado anteriormente, o fazer-panelas se configura num saber presente na família do senhor Adão há dezenas de anos. Seu pai torneava, seu avô torneava. Quando indagado sobre quando começou, o senhor Adão diz que é tão antigo que ele acha que é até indígena. Quando Cássio Eduardo Viana Hissa (2008) dialoga sobre saberes ambientais, numa crítica à ciência e a retomada de um viés epistemológico transdisciplinar, ele menciona que os saberes ambientais "emergiriam, também, da ciência voltada para as aberturas, para as fronteiras que arrastam as suas divisas: ciência que se reconstrói de modo a edificar um novo conjunto de relações com os sujeitos do mundo, para que possa dialogar com os saberes que lhe faria mais capaz, mais sensível diante do que há por interpretar (HISSA, 2008, p. 61). Neste sentido, entender o fazer-panela enquanto saber local, e também ambiental, é considera-lo parte da cultura, da memória e da história dos habitantes do Cafundão. É torna-lo parte edificante destes sujeitos, e por isso a criação do assentamento e a priorização da Cooperativa no PDA significou a proteção e a valorização cultural de tais pessoas, bem como a garantia de sua reprodução social. A 
Cooperativa tornou-se "suporte material das lembranças [que se] assenta em afetividades e efetiva acontecimentos, grupos sociais e saberes-fazeres, guarda as marcas do tempo, o movimento da história" (COSTA, 2014, p. 82).

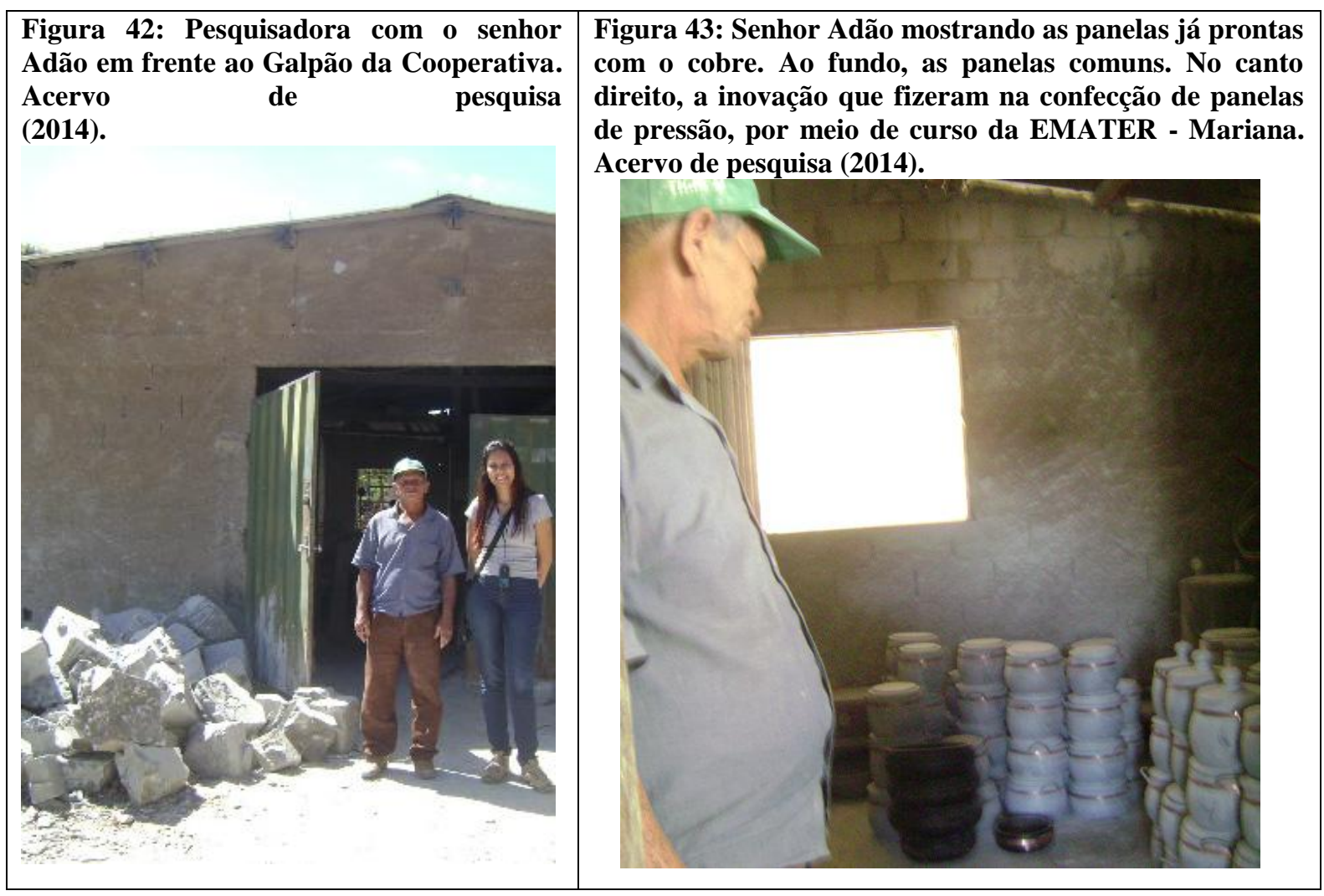

Figura 44: Blocos de esteatito em vias de torneamento no interior do galpão. Acervo de pesquisa (2014).

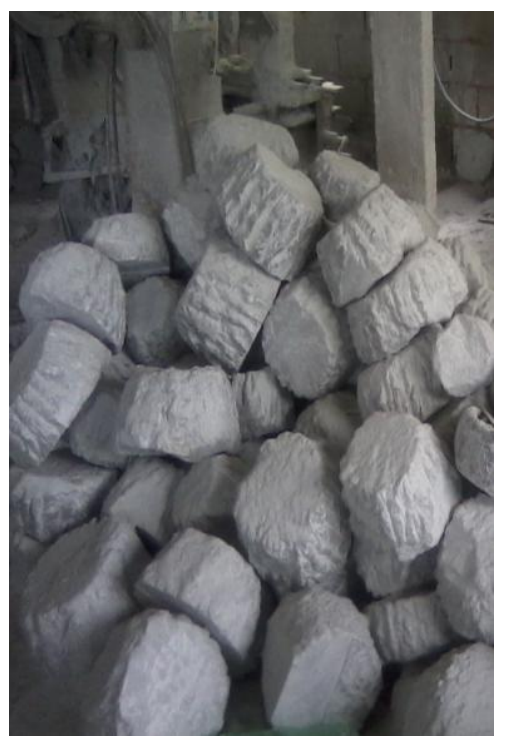

Figura 45: Neto do senhor Adão que brinca no pó da pedra antes dela servir para nutrir hortas. Acervo de pesquisa (2014).

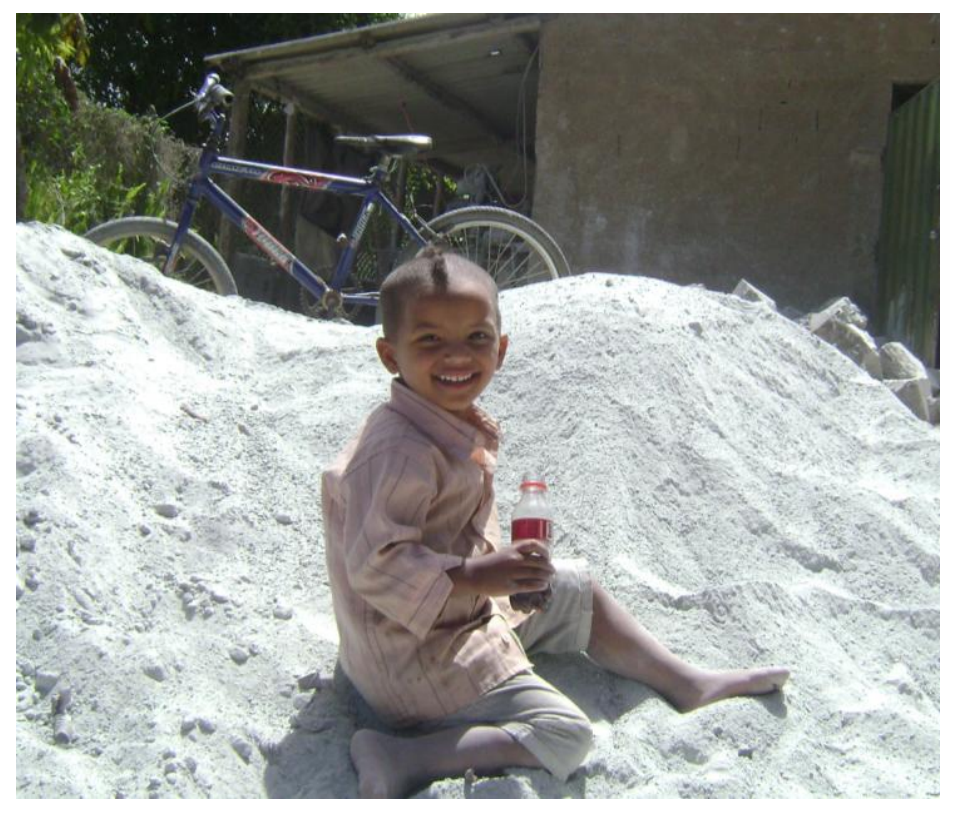




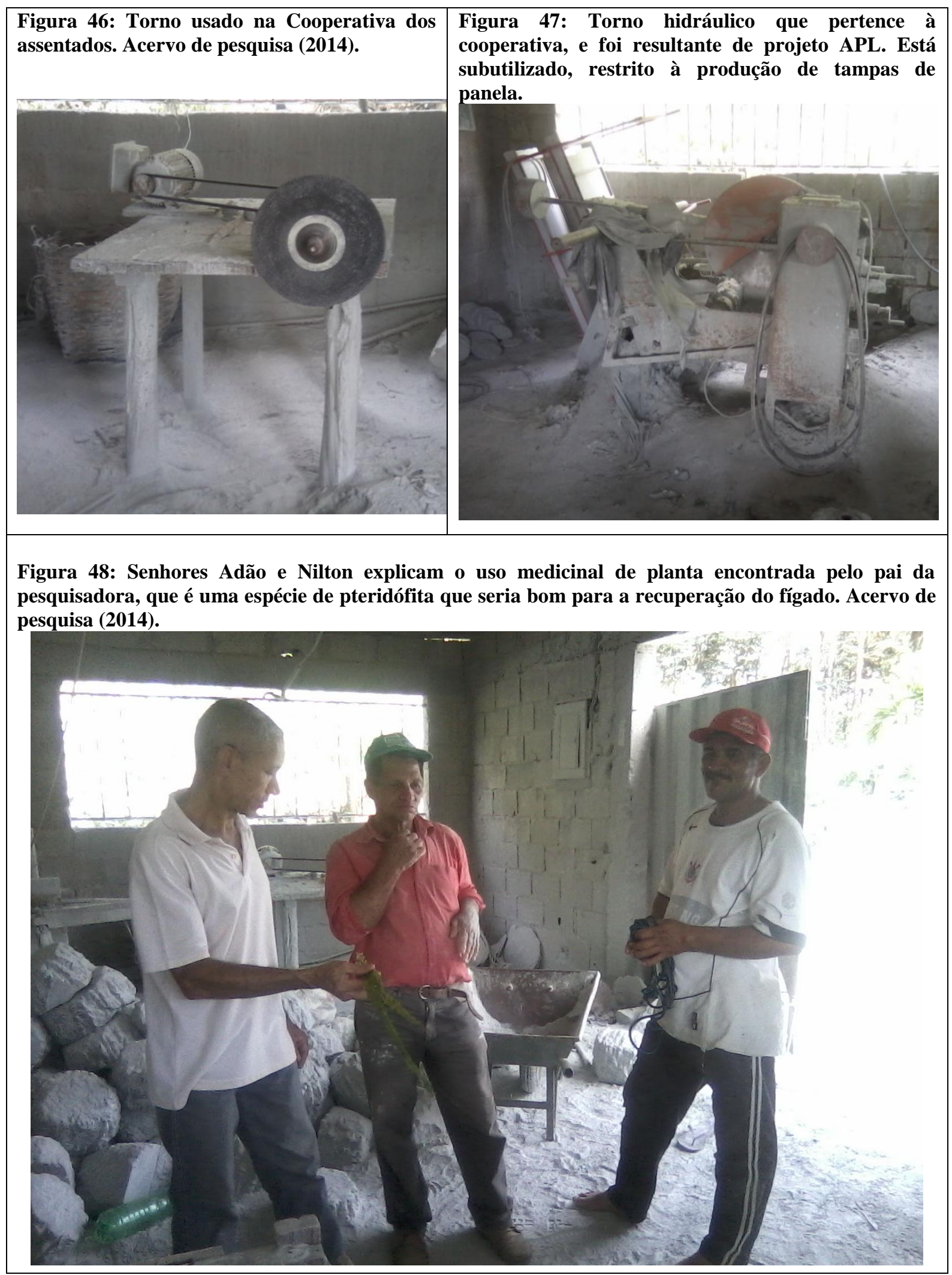


Esta reprodução social de si mesmos se dá num cenário em que é predominante em seu próprio distrito, Cachoeira do Brumado, a produção de panelas de pedra. Segundo o Relatório de Avaliação das Condições Existentes para a Estruturação do Desenvolvimento Regional Auto Sustentado, elaborado pela Fundação Centro Tecnológico de Minas Gerais - CETEC (2006), há empresas de produção de panelas de pedra há pelos menos 60 anos neste distrito, com mobilização de 600 pessoas neste ramo de produção. Este Relatório inclusive identificou um líder local que também foi vereador da cidade de Mariana durante 14 anos, que possui usina própria à geração de energia, tem pousadas, possui diversos empregados na fábrica e na lavra de blocos, com uma produção total de duas mil (2.000) panelas ao dia. Consta também o relato de que as grandes empresas mineradoras da região tem aumentado o custo da produção de panelas, já que dificulta o acesso, fornece matéria-prima de pior qualidade e com preço elevado.

Já a Cooperativa dos Assentados do Cafundão, segundo este Relatório (CETEC, 2006), está imersa numa tensão pela matéria-prima, que é o bloco de rocha esteatito. Menciona que eles têm sido alvo de monopolização por grandes empresas da região que impedem a retirada de blocos, diminuíram significamente a sua venda aos assentados, ou vendem por preços além-mercado.

Este fenômeno é comum, segundo Oswaldo Sevá (2011), em cidades que possuem enquanto atividade principal a mineração, onde convivem grandes empresas mineradoras e lavras com trabalho familiar. Este é o caso do município de Mariana, e especificamente o distrito de Cachoeira do Brumado onde convive as extrações da Anglo Gold com aquelas de Cooperativas já consolidadas no distrito e na exportação de panelas e, ainda, aquelas pautadas no trabalho familiar, como é o caso dos assentados do Cafundão. Conforme Sevá (2011, p. 3), o conflito inerente a estas escalas de produção se traduz numa "trajetória de um povo enquadrado à força, desde a escravidão, na formação capitalista brasileira. Mina grande, conflitos gerais". Além disso, a historicidade da importância que o Estado brasileiro dá para a extração e pesquisa mineral criou mecanismos burocráticos de concessão de prospecção e lavra. Tais mecanismos induzem que aqueles que possuem capital e comprovam possuir capacidades da execução da lavra garantam prioridades na concessão. A Lei institui prioridade àquele que primeiro solicita junto ao órgão responsável, que é o Departamento Nacional de Pesquisa Mineral - DNPM, ligado ao Ministério de Minas e Energia. 
Mapa 6: Localização do PA Cafundão em terras circundadas pela atividade mineradora.

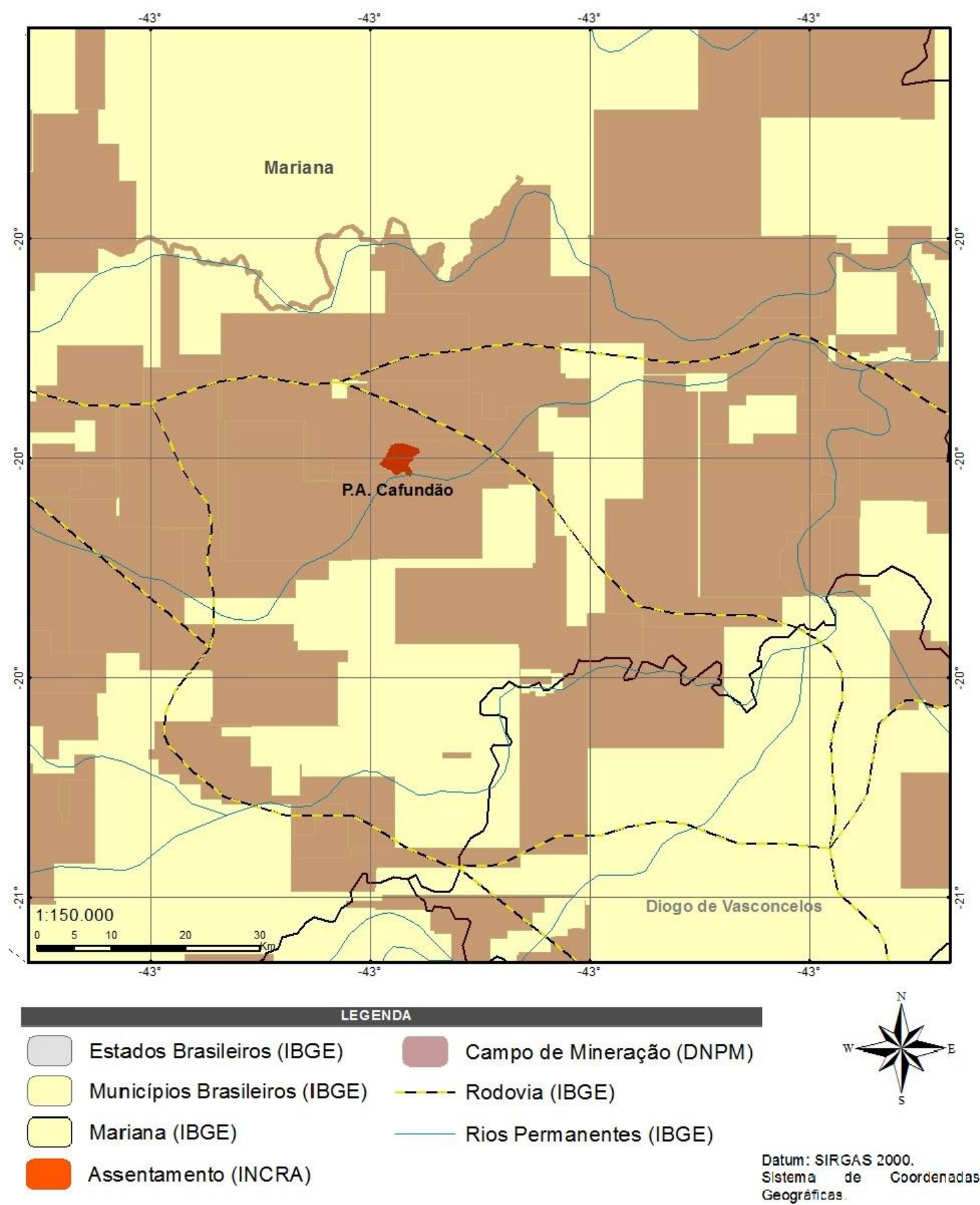

Mas, segundo Sevá (2011), na prática o pedido de prospecção é mais dificultoso por conta das operações de engenharia e laboratoriais que são requeridas. Por isso, os direitos minerários são concedidos prioritariamente a grandes empresas, que revendem ao pequeno produtor por um preço que dificulta o aumento de sua produção. Além disso, no caso do Cafundão, dependem crucialmente de atravessadores para realizar a venda de panelas, que 
ainda são vendidas por preços que não correspondem nem à metade daquilo negociado no mercado. A produção do assentamento corresponde a mil panelas por mês, cerca de 3,33\% da produção das demais empresas deste distrito.

O relatório da CETEC (2006) aponta que a EMATER, escritório Mariana, realizou alguns trabalhos importantes junto ao assentamento, o que conspirou, inclusive, para ele ser considerado consolidado pelo DOU (2002), SIPRA (2011) e SIPRA (2014). Este respaldo da EMATER-Mariana ainda continua o que, de certa forma, ameniza as consequências do encarecimento da revenda do bloco de esteatito, quando não conseguem lavrar. A participação da EMATER se dá no apoio à inserção do assentamento em políticas específicas do Plano Nacional de Reforma Agrária, que foi responsável, inclusive, pela captação de recursos ao custeamento da criação da Cooperativa. Além disso, realizou assistências técnicas ao aprimoramento da panela, incluindo a construção de fondue, de panela de pressão e de tapetes em sisal coloridos. O escritório de Mariana da EMATER coloca os assentados do Cafundão em diálogo com outros assentamentos e agricultores familiares, promovendo a participação deles em feiras agrícolas e em encontros nacionais de assentados de reforma agrária. Este diálogo por vezes significou o próprio custeamento de automóveis para transporte das panelas em feiras próximas. Em outras ocasiões, a mera divulgação do evento e a instrução de como chegar induziu a mobilização dos assentados à participação.

$\mathrm{O}$ ir numa feira, para além da venda de panelas, significa a própria divulgação de existência do assentamento em Mariana, além do compartilhamento com outras realidades e assentados. Faz-se uma leitura de que a panela, neste contexto de sociogênese do assentamento, se configura numa plural significância, que se relaciona ao vínculo com esta terra, ao trabalho que é sustento, ao saber e à memória herdada, transferida, transcriada a partir do aprimoramento. Além disso, a panela se expressa enquanto imagem representativa deste assentamento, percebida quando se questionou, durante a pesquisa, por dados e informações a ele referente, em escritórios do INCRA-MG, da EMATER-MG e EMATERMariana. Dizer que o assentamento Cafundão é o da panela de pedra promoveu um reconhecimento imediato de qual se tratava, a despeito dos casos de ausência de informações diferentes daquelas já disponíveis e encontradas na internet. Busca-se a sociogênese da luta pelo assentamento Cafundão, aquele da panela-de-pedra. A conquista em torno de ser beneficiário de reforma agrária contribui à construção da identidade ser-assentado, que sustenta a legitimidade do vínculo com a terra expressa no saber-fazer panela. 


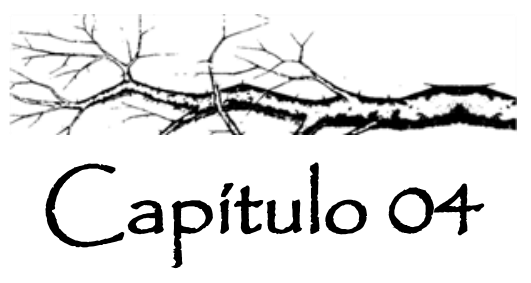

\title{
À guisa de uma conclusão:
}

\section{memórias e identidades territoriais.}

\author{
"Eu atravesso as coísas - e no meío da travessía não vejo! - \\ só estava era entretido na idéía dos lugares de saída e de \\ chegada..." (João Guimarães Rosa).
}

A sociogênese processual de luta pela terra dos assentados do Cafundão se deu através da consideração das narrativas que os assentados possuem de sua luta, dos documentos guardados pelo senhor Adão num envelope pardo, bem como de fontes documentais que revelam características do contexto de análise. Respeitou-se a composição com a qual se deparou $_{2}$ que diz respeito ao arranjo de lideranças: tinha-se o representante elencado para se falar sobre o histórico de luta pela terra, somando-se àquilo apreendido através da Travessia. Esta liderança, que é o senhor Adão, carrega em si mesmo a legitimidade da luta, pois é hoje o herdeiro mais velho destas terras e é também o mais anfitrião na tarefa de saber-fazer panela.

O saber-fazer panela emerge enquanto vínculo íntimo com a terra do Cafundão e disporia, portanto, sobre memórias e identidades territoriais. O saber tornear esteatito à produção artesanal de utensílios foi apreendido enquanto espécie de prova de que eles seriam realmente destas terras, a despeito de hoje serem assentados de reforma agrária. Para Maria José Carneiro (1998, p. 74), o saber-fazer descreve uma forma de "reconhecimento de um determinado espaço como próprio ao indivíduo, à família e ao grupo mais amplo", e está pautado em uma memória coletiva ligada à herança de gerações anteriores.

A menção de que o saber-fazer já faz parte da família há anos desconhecidos, sendo que o senhor Adão aprendeu e herdou os tornos de seu avô Francisco, falecido no início da década de 1990 com 106 anos de idade, ratifica a ideia de uma historicidade de relação com esta terra específica, onde guardam as suas memórias e identidades, incluindo aquela do ser- 
assentado de reforma agrária. Memória e identidade, no sentido geográfico, apresentado por Costa (2014, p. 80), para quem a "a memória constitui um fenômeno particular de correlação, de resgate, de projeção, em suma, de reprodução presente do espaço-tempo em seu devir histórico", enquanto que a "identidade é enraizamento, é sobreposição de objetos e ações e a identificação com estes mesmos elementos" (COSTA, 2014, p. 82).

Em sentido mais amplo, para Halbwachs (1990), a memória coletiva se assenta, em força e durabilidade, no grupo social - que é um conjunto de indivíduos - e a lembrança que possuem do passado emerge enquanto forma de caracterizá-lo enquanto membros desse grupo. Este autor se aproxima de Pollak (1982), que considera uma base comum que passa a ser inerente à existência de um grupo e à caracterização dos elementos que a ele pertencem. Ser-assentado de reforma agrária e a própria tensão da luta pela terra do Cafundão nutriu a existência deste grupo social, que se une numa base comum de luta e reforça laços familiares.

Figura 49: Cooperativa de Panelas de Pedra dos assentados do Cafundão. Acervo de pesquisa (2014).

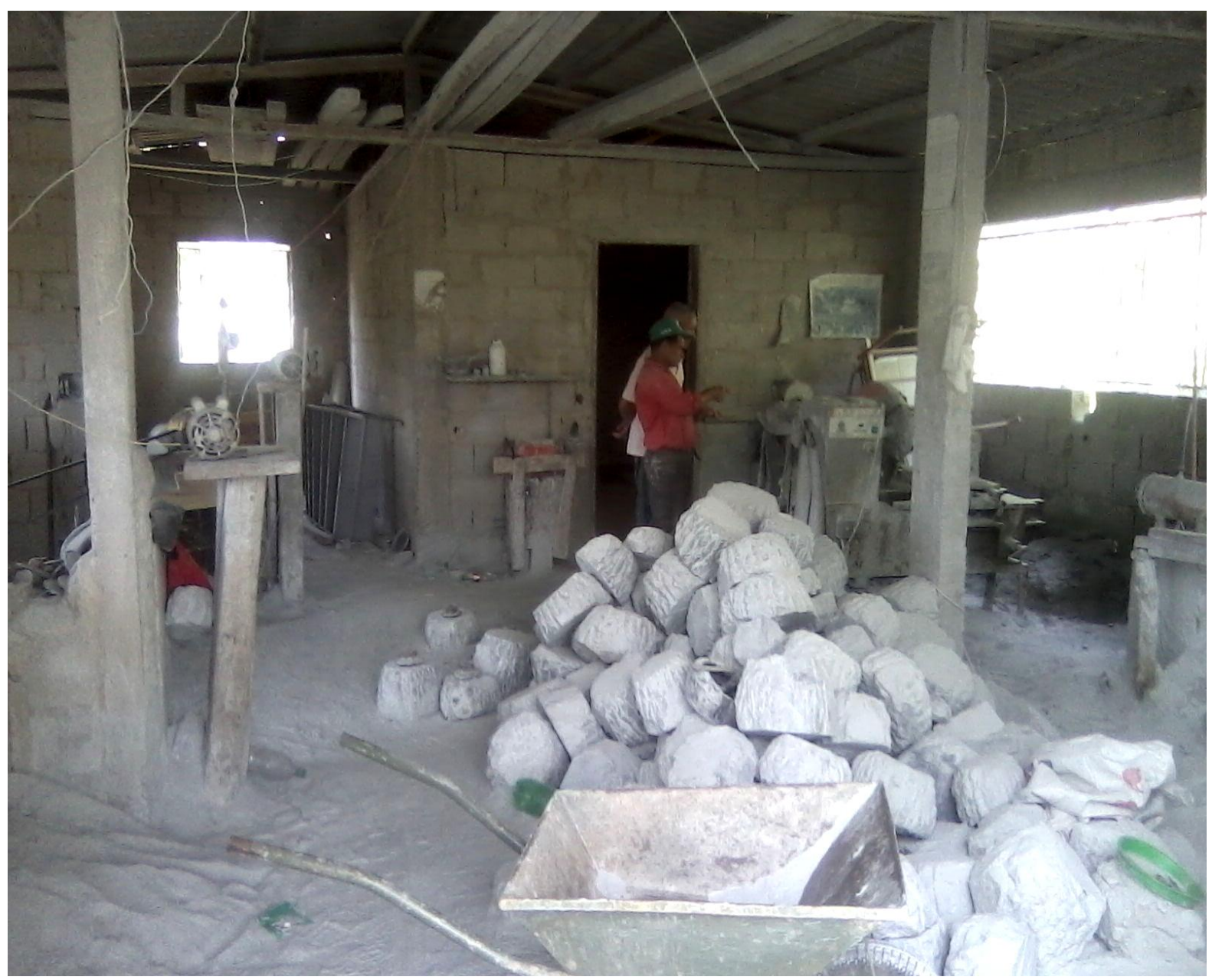


Percebeu-se que a efetivação da política pública de reforma agrária significou a resolução de uma tensão profunda acerca da posse da terra, além de proporcionar acesso a outras poucas famílias não pertencentes àquela do senhor Adão. A resolução em patamar federal contribuiu para a reprodução social destas famílias ligadas à terra de uma forma peculiar, na medida em que o tornear é tarefa principal e fundamental neste assentamento

A indagação acerca do que fariam se o INCRA tivesse orientado que eles fossem para outras terras senão estas, é respondida com um silêncio profundo, seguido da menção de que teriam que pegar suas coisas e ir, por que é lá que eles reservaram pra nós. O ser-assentado emerge amplamente enquanto garantia do acesso a terra, bem como a ratificação da legitimidade de que uma família é dali originada, herdeira e, por isso, o Cafundão era lugar antes de ser assentamento. "Se os habitantes de uma cidade ou de um quarteirão formam uma pequena sociedade, é porque estão reunidos numa mesma região do espaço. Deve-se dizer que isto é apenas uma condição da existência desses grupos, mas uma condição essencial e muito clara" (HALBWACHS, 1990, p. 139).

O saber-fazer panelas, além de caracterizar um lugar, pois é também vínculo com a terra pela qual se lutou, significou, portanto, a territorialização das memórias e das identidades. As terras do Cafundão, enquanto lugar, servem para justificar o porquê da decisão em resistir e recorrer ao INCRA. Há menções de que eles nunca quiseram briga. A busca por legitimar-se na terra é encarada enquanto via que se recorreu para garantir suas permanências, a reprodução de si mesmos, a defesa de poder-ser, e isto é também identidade.

Resistir foi uma tensão instaurada, na qual a política de reforma agrária serviu enquanto juiz desta briga, deste impasse. Para os assentados, se eles são hoje assentados, é porque se reconheceu o direito de eles ali viverem. O juiz-Estado interfere a favor da continuidade de suas vidas, que passa a incorporar a feição do ser-assentado. Esta feição se desdobra em corroborar, institucionalmente por meio da política, a memória da relação que possuem com esta terra. O ser-assentado, além da promoção do acesso, serve de ratificação de si mesmos socialmente, além da promoção de visibilidade à venda de seus produtos artesanais que carregam o signo ser-assentado. Neste sentido, para Halbwachs (1990, p. 145), “[...] um homem ou vários homens somente adquirem direito de propriedade sobre uma terra ou uma coisa, a partir do momento em que a sociedade da qual são membros admite a existência de uma relação permanente entre eles e essa terra ou essa coisa, ou que essa relação é tão imutável como a coisa em si mesma”. Esta forma de reconhecimento social da reprodução de 
um grupo específico se faz por meio da memória coletiva, que instaura oportunidades de intervir ou não a favor da aplicação deste reconhecimento, em suas formas amplas que inclui aspectos jurídicos e institucionais de memória.

O Cafundão hoje é o território onde as memórias e as identidades nele foram construídas, ainda tensionam e se reconstroem na vida cotidiana e na tarefa diária de fazer panela. A ocorrência da rocha esteatito, ou a possibilidade de comprar em lavras, serve como uma das regionalizações possíveis que envolvem o ser-assentado. A reprodução destes, tal como hoje se instaura, está de certa forma intricada ao afloramento da rocha que fundamenta e garante o saber-fazer panela. Percebe-se que há a emergência de uma região sob o critério que é o da rocha que se torneia, o que inclui suas redes de aquisição e comercialização. "Não nos encontramos, aliás, num espaço indeterminado, porém em regiões que conhecemos, ou as quais sabemos muito bem que poderíamos localizar, já que sempre fazem parte do meio material onde estamos hoje" (HALBWACHS, 1990, p. 160).

Regionalizar torna-se, neste caso enfocado, uma delimitação - diferente de limitação! sob critérios que a embasam. Os assentados de reforma agrária, na medida em que se dedicam ao saber-fazer panela, criam a própria região de si mesmos. E, por isso, se percebe que há tensões em torno desta regionalização, que contribui, principalmente, para que filhos de assentados tentem transpor esta delimitação através do trabalho em outras empresas e que possui também outros sentidos. A dimensão artesanal da produção de panelas do assentamento, de certa forma, induz que os filhos dos assentados recorram a meios mais rápidos de adquirirem o dinheiro que seria oriundo da venda de panelas que se dá por meio, principalmente, de atravessador. Desta maneira, inserem-se em trabalhos ligados a empreiteiras de mineração e metalúrgica, a despeito de por vezes retornar ao assentamento para auxiliarem seus pais ou para retomarem o saber-fazer panela enquanto forma mais segura de viver suas vidas.

O saber-fazer instaura um espaço-tempo diferenciado de vida. "Quando um grupo humano vive muito tempo em lugar adaptado a seus hábitos, não somente os seus movimentos, mas também seus pensamentos se regulam pela sucessão das imagens que lhe representam os objetos exteriores" (HALBWACHS, 1990, p. 136). Torna-se importante o trabalhar para si mesmo, e não possuir patrão. O estar sempre perto de casa, com horários flexíveis, inclusive. O almoçar em casa, com a rotina diária do descanso no pós-almoço. $\mathrm{O}$ trabalhar com o sol: acorda-se quando ele surge, e se interrompe o trabalho quando ele vai-se 
embora. A pressão pelo número de panelas feitas se dá no nível de dispor sobre a própria renda. Planta-se o básico, incluindo verduras e frutas, e o resto a venda da panela ajuda a conseguir; é um trabalho ligado à terra. Aos poucos, os filhos aprendem a juntar dinheiro e ir comprando cada tijolo por vez: já pensam na construção de suas futuras casas, para suas futuras famílias, desde cedo. Os pais reservam frações de seu lote para que toda a família tenha acesso a terra e meios de se garantirem. Assim, “[...] é nas cidades menores, um pouco afastadas das grandes correntes [...] onde a vida é ainda regulada e ritmada como o era entre nós há um ou dois séculos que as tradições locais são mais estáveis [...]” (HALBWACHS, 1990, p. 136).

Figura 50: Assentado que fora baleado no episódio de luta pela terra do Cafundão, com sua foice que é uma ferramenta agrícola. Acervo de pesquisa (2014).

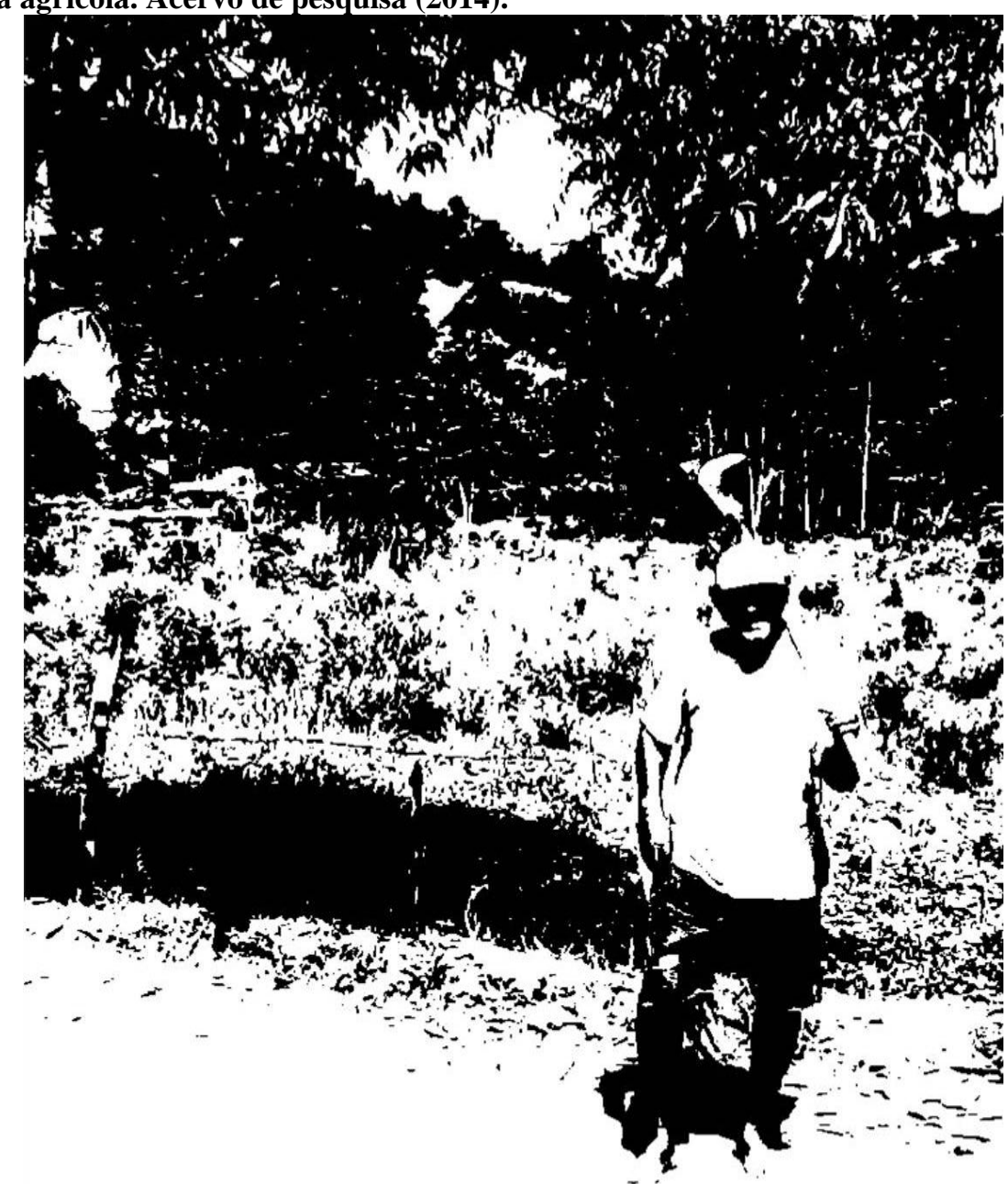

O saber-fazer é o que torna o Cafundão um lugar, de vida, morada e esperanças. O saber-fazer territorializou o Cafundão através da luta por estas terras, e das negociações de 
memórias e de identidades em torno dele: os objetivos diferenciados de vida circundam o saber-fazer, até mesmo em sua negação. Este saber-fazer, de certa forma, cria também a região enquanto delimitação. Delimitar é diferente de limitar, e dispõe sobre a garantia da reprodução social deste grupo. "Quando um grupo está inserido numa parte do espaço, ele a transforma à sua imagem, ao mesmo tempo em que se sujeita e se adapta às coisas materiais que a ele resistem. Ele se fecha no quadro que construiu". (HALBWACHS, 1990, p. 132).

Ao transpor esta delimitação, quando o seu critério criador ou suporte material que é o da rocha esteatito estiver escasso, de alguma forma a reprodução se dará sobre outros novos critérios e, por isso, outras regionalizações, novas significações. Talvez possa ser através da mudança para a sede do município de Mariana, enquanto referência de cidade que converge oportunidades de empregos plurais. Para Carneiro (1998), conceber as relações específicas que caracterizariam um mundo rural como ruralidade é abrir-se à apreensão de seus movimentos, suas recriações, suas constantes ressignificações. Neste sentido, a vida na terra não seria contraposta à saída para a cidade: mudar-se para a cidade reformula a ruralidade dos grupos sociais. "Nesses termos, não podemos entender a ruralidade hoje somente a partir da penetração do mundo urbano-industrial no que era definido tradicionalmente como "rural'" (CARNEIRO, 1998, p. 69). A ruralidade, como bem simbólico, material e que envolve práticas culturais, poder-se-ia ser incorporado pela sociedade urbano-industrial, o que redefine as fronteiras entre o urbano e o rural, através da investigação das práticas sociais de seus agentes. Por conseguinte, outras atividades que não agrícolas, tal como o torneamento de panela, passam a ser concebidas em seu significado de relação íntima com a terra, descreve ruralidades e é encarada enquanto pluriatividade. Como também, a cultura country (CARNEIRO, 1998), por exemplo, passa a ser concebida enquanto resultante da interseção das práticas sociais que descrevem urbanidades e ruralidades.

Porquanto, percebeu-se outra forma de este espaço-tempo estar representado. Ele se dá através de um marco territorial que descreve memórias e identidades. Fala-se da importância percebida da cerca, quando ela se faz presente, ou onde ela já esteve um dia. "As territorialidades são expressas de forma simbólica, como o muro e a cerca que definem limites. Muitos símbolos que representam as territorialidades não são materiais, mas estão expressos no espaço como se um muro físico ali existisse” (PIDNER, 2010, p.86).

Para além de significar ser somente um limite, ou seja, o que demarca territórios, a cerca foi percebida enquanto incentivo de memória, enquanto fronteira entre os espaços- 
tempos. "[...] enquanto fronteira, imaginada do mesmo lugar, está voltada para fora, como se pretendesse a expansão daquilo que lhe deu origem. O limite estimula a ideia sobre a distância e a separação, enquanto a fronteira movimenta a reflexão sobre o contato e a integração" (HISSA, 2002, p. 34). A cerca, que é fronteira que aproxima espaços tempos e que limita territórios, é representada "por imagens, reconfigurada por imaginários e cultuada por imaginações" (COSTA, 2014, p. 84).

Deparou-se com uma situação mediante a placa de entrada da Fazenda Cafundão encontrada durante a Travessia. Ao indagar o senhor Adão acerca de quem colocou aquela placa, que está no ponto mais baixo da vertente, ele responde que foi alguém [que] pôs isso ai. Pediu-se para que ele ficasse mais perto da placa, para que uma foto fosse tirada marcando a entrada do assentamento. Sem mover os pés, ele, que estava há uns 20 metros vertente acima, grita que a foto tinha que ser tirada lá, e não aí. Tirou-se esta foto da placa sozinha, e encaminhou-se na direção do senhor Adão. A foto que ele queria foi tirada, e só se percebeu posteriormente, ao grava-las num pen drive, a importância desta.

Figura 51: Placa colocada na entrada da Fazenda Cafundão. Há alguns metros dali, o senhor Adão considera que começa o assentamento, a despeito de este ponto já pertencê-lo, conforme INCRA (2014). Acervo de pesquisa (2014).

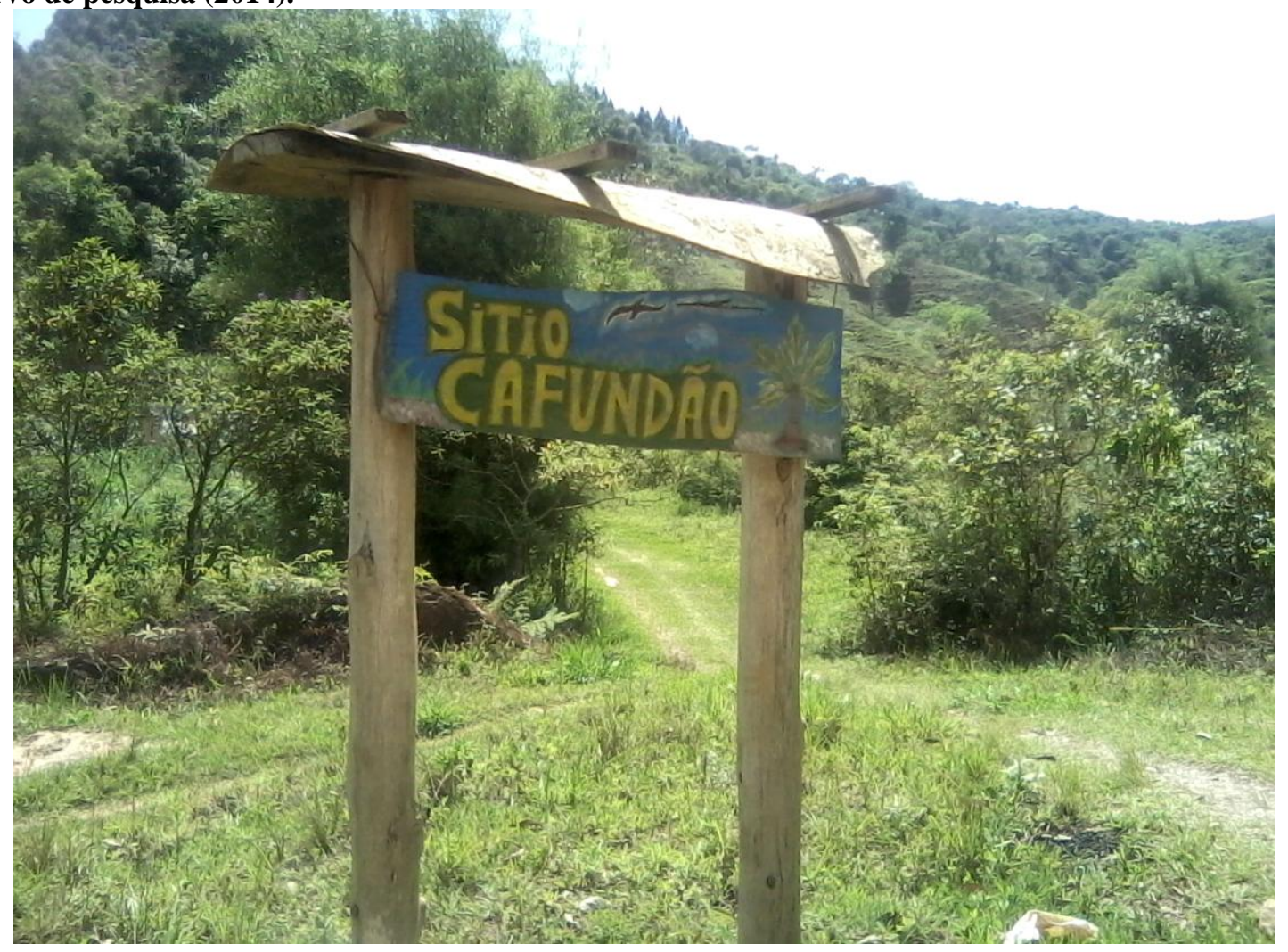


Figura 52: Cerca, à esquerda, que marca para o senhor Adão o início do assentamento Cafundão. Acervo de pesquisa (2014).

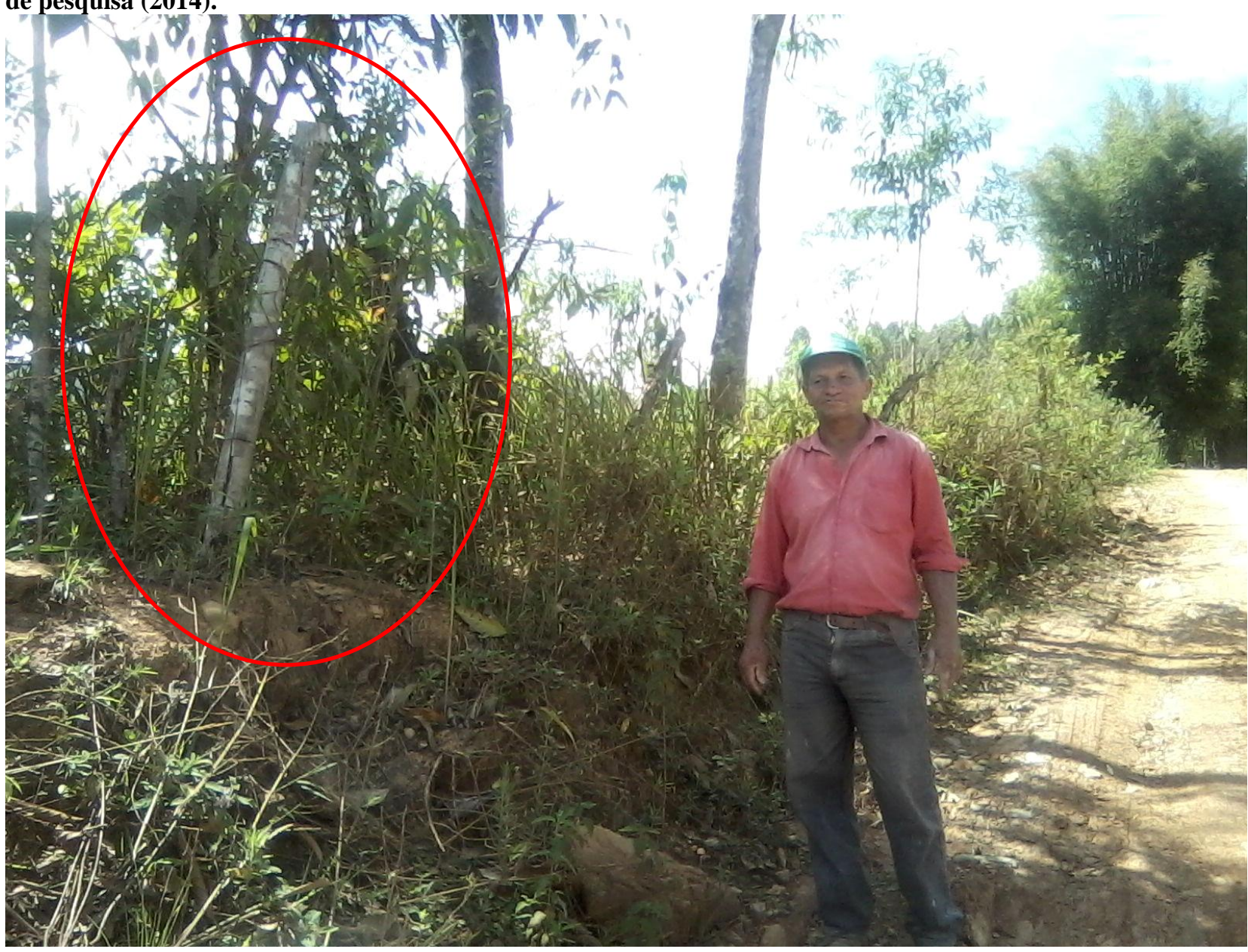

Confirmou-se, também, a partir desta ocasião que a cerca descreve um marco de território, em sua dimensão identitária e mnemônica. Instaura limites e fronteiras, que se dão a partir da relação intrínseca entre memória e identidade, ao mesmo tempo em que serve de orientação, de paisagem-memória, e de incentivo que conspira para remontar a eventos. Para Costa (2014, p. 85), a memória reclama por suportes materiais que a dão durabilidade, capacidade intelectiva, permite sua recriação, reavivamento, relações com os espaços-tempos, descreve marcas, esperanças e sonhos. A cerca é suporte material e compõe uma paisagem que é estímulo de representações. E esta fotografia tirada do senhor Adão serviu de “iconografia [que] possibilita a construção de paisagens-memória", como avalia Costa (2014, p. 85) a função social-histórica da fotografia.

Neste sentido, a Fazenda Cafundão que pertenceu um dia à família do senhor Adão, onde o assentamento está localizado em 30\% destas terras, assume as versões de ser um patrimônio territorial (MOURA, 1978) mnemônico. Não há pretensões de tentar outras vias 
para retomar as terras que, nas entrelinhas das palavras, o senhor Adão diz ter, de certa forma, perdido. Ele agradece que o impasse tenha sido resolvido e que hoje ele possua seu lote para viver com sua família. Mas, a memória de onde estavam dispostas as cercas ainda subsiste. A identificação com certos pontos da Fazenda onde se moía milho, descansava no pós-almoço, nadava nos riachos, e se escondia entre as pedras para se ficar sozinho, é ainda percebida e descrito, apontado, lembrado pelo senhor Adão, grandemente através do incentivo de memória que é a cerca.

A abertura suscitada por esta pesquisa diz respeito a conceber as relações plurais que se dão entre espaço, memória e identidade. No caso do Cafundão, percebeu-se que o espaço se territorializa a partir da cerca. A cerca converge representações, imaginações e lembranças. A cerca, e o fato de que hoje ninguém a derruba, é confirmação de legitimidade de uma vida na terra, que se dá também por meio do saber-fazer panela que descreve um vínculo. $O$ possuir uma cerca guarda em si o acesso a terra, o lugar onde os Eu's plurais podem ser, em seu sentido amplo. A cerca é encontro e separação entre um Eu e Outro, entre vizinhança, entre diferentes. Ela emoldura as áreas de passagem, se faz presente nas estradas, se evidencia numa paisagem campestre. A cerca é presença, que incita desvios, aberturas, requer que se identifique.

Percebeu-se que a cerca descreve ruralidades profundas, que se aproximam sim de modos de vida, como diz Carneiro (1998), mas vai além. Incita espaços-tempos diferenciados, guarda signos e representações, é suporte ao narrar vidas, o que Le Goff (1924) denomina como ato mnemônico fundamental. Concebe-se, portanto, a cerca enquanto materialidade resultante do que se chama de racionalidade camponesa. Desta forma, “[...] a 'racionalidade camponesa' pode persistir no contexto de predominância da sociedade urbano-industrial desde que ela não seja percebida como um modelo cristalizado, uniforme e a-histórico, no sentido de uma cultura específica e universal" (CARNEIRO, 1998, p. 74). Para a autora, a racionalidade camponesa expressaria visões de mundo pautadas nas relações sociais específicas, que ressignifica o mundo do qual faz parte. "É nesse contexto que [...] devemos produzir novos conhecimentos sobre o chamado "mundo rural" [...] e entender a pluriatividade como uma forma alternativa de explorar a agricultura e, em conseqüência, como uma possibilidade de reelaboração de identidades sociais (CARNEIRO, 1998, p. 74).

Há aberturas suscitadas por essa pesquisa que reside na investigação da cerca, enquanto conceito que incita a racionalidade camponesa das feições rurais do espaço 
brasileiro. A cerca, enquanto expressão da territorialidade, de memórias e de identidades, descreve espaços onde se dão relações sociais específicas que se caracterizam em ruralidades. A este mundo rural, lido a partir de sua constante ressignificação, também pertencem atividades não-agrícolas enquanto pluriatividade, ou seja, outras formas de garantir-se na terra. A designação rural tornar-se foco de reflexão epistemológica, e de rearranjo ao contexto brasileiro e àquele específico a ser enfocado. É possível que se consiga, futuramente, aproximações e distanciamentos entre os significados e as significâncias da cerca em meios que se julgam enquanto rurais, e das calçadas, naqueles urbanos. Ambos servem de estímulo às memórias, servem de fronteira-limite entre o Eu-Outro, e se traduzem em territorialidades de espaço. 


\section{REFERÊNCIAS}

ABREU, Luciano Aronne de. Getúlio Vargas: a construção de um mito (1928-1930). Porto Alegre: EDIPUCRS, 1996, 132p.

ALBUQUERQUE, Francisco José Batista.; COELHO, Jorge Artur Peçanha de Miranda.; VASCONCELOS, Tatiana Cristina. As políticas públicas e os projetos de assentamento. Estudos de Psicologia 2004, 9(1), 81-88.

ALVES FILHO, Eloy; SALCIDES, Arlete Maria Feijó; ALVES, Gillian Del Puppo. Saberes Tradicionais Utilizados pelos Trabalhadores Rurais assentados em Minas Gerais. In: XIII Congresso Brasileiro de Sociologia, 2007, Recife. XIII Congresso Brasileiro de Sociologia, 2007.

ALVES FILHO, Eloy; SALCIDES, Arlete Maria Feijó; ALVES, Gillian Del Puppo. E A LUTA CONTINUA: APÓS CONQUISTA DA TERRA, ASSENTADOS DE MINAS GERAIS REIVINDICAM MAIS APOIO E INFRAESTRUTURA. In: XLVI Congresso da SOBER, 2008, Rio Branco. Resumos do XLVI Congresso da SOBER, 2008.

ALVES FILHO, Eloy; SALCIDES, Arlete Maria Feijó. Expectativas de futuro de jovens assentados. In: $\mathbf{X}$ Congresso Luso-Afro-Brasileiro de Ciências Sociais Sociedades Desiguais e Paradigmas em Confronto, 2009, Braga. Livro de Resumos do X Congresso Luso-Afro-Brasileiro de Ciências Sociais Sociedades Desiguais e Paradigmas em Confronto. Braga, 2009. p. 39-39.

ALVES FILHO, Eloy; SALCIDES, Arlete Maria Feijó. A Reforma Agrária e a desconcentração de terra, de renda e de população. Revista História Social, v. 2, p. 173-192, 2011.

ANDRADA e SILVA, José Bonifácio. Representação à Assembleia Geral Constituinte e Legislativa do Império do Brasil sobre a escravatura. 1840. In: Projeto para o Brasil - Org. Miriam Dolhnikoff. Companhia. Das Letras, 1998, p. 45-82; p. 181.

ARAÚJO, Maria Celina d'. Sindicados, carisma e poder: O PTB de 1945-65. Rio de Janeiro: Editora Fundação Getúlio Vagas, 1996, 192p.

AZEVEDO, Dermi. A Igreja Católica e seu papel político no Brasil. Estudos Avançados: Dossiê Religiões no Brasil. Volume 18, n 52. São Paulo, setembro-dezembro, 2004. ISSN 0103-4014.

BETTO, Frei. Agronegócio e Agricultura Familiar. Terra Azul: 2005.

BHABHA, Homi K. O pós-colonial e o pós-moderno. In: O local da cultura. Belo Horizonte: EdUFMG, 1998. 
BOTELHO, Tarcísio Rodrigues. População e escravidão nas Minas Gerais, c. 1720. $12^{\circ}$ Encontro da Associação Brasileira de Estudos de População - ABEP, GT, População e História, realizado em Caxambu (MG), outubro de 2000.

BRANDÃO, Rafael Vaz da Motta. Ajuste Neoliberal no Brasil: desnacionalização e privatização do sistema bancário no governo Fernando Henrique Cardoso (1995/2002). Niterói, Universidade Federal Fluminense, 2013 (Tese de Doutorado).

BRUMER, Anita. Previdência social rural e gênero. Sociologias, Porto Alegre, ano 4, $\mathrm{n}^{\circ} 7$, jan/jun 2002, p. 50-81

CABRAL, Carlos Castilho. Terras devolutas e prescrição. Rio de Janeiro: Jornal do Comércio, 1943, p. 38.

CARINHATO, Pedro Henrique. Neoliberalismo, Reforma do Estado e Políticas Sociais nas últimas décadas do século XX no Brasil. UNESP: AURORA, ano II, número 3 DEZEMBRO DE 2008. ISSN: 1982-8004

CARNEIRO, Maria José. Ruralidade: novas identidades em construção. Estudos Sociedade e agricultura, 1998, p. $53-75$.

CARRARA, Angelo Alves. Contribuição para a história agrária de Minas Gerais séculos XVIII-XIX. Mariana: Universidade Federal de Ouro Preto, Departamento de História, Núcleo de História Econômica e Demográfica, 1999, 90p. ISBN 85-288-0029-6.

COSTA, Everaldo Batista da. Paisagem-memória e função social da fotografia. In: Geografia e Fotografia: apontamentos teóricos e metodológicos. Org. STEINKE, Valdir A. et al. Brasília: LAGIM, UnB, 2014, p. 79-106.

COSTA, Everaldo Batista da. STEINKE, Valdir Adilson.Brasília meta-síntese do poder no controle e articulação do território nacional. Scripta Nova Revista Electrónica de Geografía y Ciencias Sociales. Barcelona: Universidad de Barcelona. Vol. XVIII, núm. 493 (44), 1 de noviembre de 2014 ..

COSTA, Everaldo Batista da y Júlio César SUZUKI. A ideologia espacial constitutiva do Estado nacional brasileiro. Scripta Nova. Revista Electrónica de Geografía y Ciencias Sociales. Barcelona: Universidad de Barcelona, vol. XVI, nº 418 (6), 1 de noviembre de 2012,

DEL PRIORE, Mary. VENÂNCIO, Renato. O MST e o agronegócio. Capítulo 12. In: Uma História da vida rural no Brasil. Rio de Janeiro: Ediouro, 2006a, p. 204 - 215.

Ambiguidades da reforma agrária. Capítulo 11. In:

Uma História da vida rural no Brasil. Rio de Janeiro: Ediouro, 2006b, p. 204 - 215.

DELGADO, Lucília de Almeida Neves. História oral: memória, tempo, identidade. Belo Horizonte: Autêntica, 2006. 
D'INCAO, Maria da Conceição. Governo de Transição: entre o velho e o novo projeto político de reforma Agrária. Lua Nova, CEDEC, 20, maio 1990.

ELIAS, Norbert. A sociedade dos indivíduos. Rio de Janeiro: Jorge Zahar, 1994. 188p.

FERNANDES, Bernardo M. O MST e as Reformas Agrárias no Brasil. OSAL Observatório Social de America Latina. Debates. Buenos Aires, ano IX, número 24, p. 73 85. 2008.

FERRANTE, Vera Lucia Silveira Botta. O Estatuto do Trabalhador Rural e o Funrural. Perspectivas: Revista de Ciências Sociais, Unesp, 1976, p. 188-202.

FONSECA, Claudia Damasceno. Urbs e civitas: a formação dos espaços e territórios urbanos nas minas setecentistas.An. mus. paul. [online]. 2012, vol.20, n.1, pp. 77-108. ISSN 0101-4714.

FOUCAULT, Michel. Sobre a geografia. In: FOUCAUL, Michel. Microfísica do poder. Organização e tradução de Roberto Machado. - Rio de Janeiro: Edições Graal, 1979, p.153165.

GEERTZ, Clifford. Uma descrição densa: por uma teoria interpretativa da cultura. In: A Interpretação das Culturas. Rio de Janeiro: LTC, 1989 [1973], p. 13-41.

GUANZIROLI, Carlos E. Reforma Agrária e Globalização da economia: o caso do Brasil. Reforma Agrária e Desenvolvimento Sustentável, Ministério do Desenvolvimento Agrário, Brasília: 2000.

HAESBAERT, Rogério. Da desterritorialização à multiterritorialidade. Anais do X Encontro de Geógrafos da América Latina. Universidade de São Paulo, 20 a 26 de março de 2005.

HALBWACHS, Maurice. A memória coletiva. Tradução de Laurent Léon Shaffter. São Paulo: Editora Vértice, 1990, 189f.

HISSA, Cássio Eduardo Viana. Saberes Ambientais: prevalência da abertura. In: Saberes Ambientais: desafios para o conhecimento disciplinar. Belo Horizonte: Editora UFMG, 2008, p. 46-63.

HISSA, Cássio Eduardo Viana. A mobilidade das fronteiras: inserções da geografia na crise da modernidade. Belo Horizonte: Ed. UFMG, 2002.

JASMIN, Marcelo. Utopia: memória, palavra, conceito. In: STARLING, Heloisa Maria Murgel. RODRIGUES, Henrique Estrada. TELLES, Marcella. Utopias agrárias, Editora UFMG, 2008, p. 25 - 49.

LANDINI, Tatiana Savoia. Escritos \& ensaios: Norbert Elias em perspectiva. Revista Brasileira de ciências Sociais. Junho, 2007, vol. 22, nº 64, p. 169-173. 
LE GOFF, Jacques, 1924. História e memória. Tradução Bernardo Leitão ... [et al.] -Campinas, SP. Editora da UNICAMP, 1990.

LINDÓN, Alícia. De lãs Geografías constructivistas a lãs narrativas de vidas espaciales como metodolgías geográficas cualitativas. Revista ANPEGE, v.4, p.03-27, 2008.

LUXEMBURGO, Rosa. O Socialismo e as Igrejas: o Comunismo dos Primeiros Cristãos. Editora: Achiame, Série Pensamento e Ação, Volume 01, 1980.

MALINOWSKI, Bronislaw. Argonautas do pacífico ocidental: um relato do empreendimento e da aventura dos nativos nosarquipélagos de Nova Guiné Melanésia. São Paulo: Abril Cultural, 1976. 436 p.

MALUF, Adriana Caldas do rego Freitas Dabus. Novas modalidades de família na pósmodernidade. Faculdade de Direito da USP, São Paulo, 2010. (Tese de doutorado)

MARTINS, José de Souza. O cativeiro da terra. [1979] Quarta edição. Editora Hucitec: São Paulo, 1990, 161p.

MARTINS, Rodrigo Constante. Modernização e relações de trabalho na agricultura brasileira. Agrária. São Paulo, nº, pp.165-184, 2006.

MEIHY, José Carlos Sebe Bom. Manual de História Oral. 5ed. São Paulo: Loyola, 2009, p.107-215.

MELO, Adriana Ferreira de. O lugar-sertão: grafias e rasuras. Belo Horizonte: Universidade Federal de Minas Gerais, Instituto de Geociências, Programa de Pós-graduação em Geografia, 2006. (Dissertação de mestrado)

MIRANDA, Luiz Francisco A. Voltaire e a sociogênese do conceito de civilização: a importância histórica da corte. In: Simposio Internacional Proceso Civilizador. 11., 2008, Buenos Aires. Anais... Buenos Aires: Universidad de Buenos Aires, 2008. p. 393-400.

MOURA, Margarida Maria. Os herdeiros da terra: parentesco e herança numa área rural. Editora Hucitec, São Paulo, 1978.

NABUCO, Joaquim. O Abolicionismo. 1883. São Paulo: Publifolha, 2000, 104pp.

NOSELLA, Paollo. Ética e Pesquisa. Educ. Soc., Campinas, vol. 29, n. 102, p. 255-273, jan./abr. 2008.

NOZOE, Nelson. Sesmarias e Apossamento de Terras no Brasil Colônia. Economia, Brasília (DF), v.7, n.3, p.587-605, set/dez 2006.

OLIVEIRA, Ariovaldo Umbelino. A Geografia Agrária e as Transformações Territoriais Recentes no Campo Brasileiro. In: CARLOS, A. F. A. (Org.), Novos Caminhos da Geografia. São Paulo, Contexto, 1999. 
OLIVEIRA, Fabrício Roberto Costa.; ROTHMAN, Franklin Daniel. Arquidiocese de Mariana, Teologia da Libertação e Emergência do Movimento dos Atingidos por Barragens do Alto Rio Doce (MG). Política \& Sociedade. Número 12, de abril de 2008.

OLIVEIRA, Roberto Cardoso de. O Trabalho do Antropólogo: Olhar, Ouvir, Escrever. Revista de Antropologia, São Paulo, USP, 1996, v.39, nº1.

OLIVEIRA, Fabrício Roberto Costa.; SCHIAVO, Reinaldo Azevedo. Da teologia ao rural: reflexões acerca de ideias religiosas e concepções políticas na Arquidiocese de Mariana. Revista IDEAS, v. 2, n. 2, p. 203-230, jul.-dez. 2008.

PAULA, Amir El Hakin. As territorialidades dos sindicatos no Brasil do início do século XX aos anos de 1930, GEOUSP - Espaço e Tempo, São Paulo, Edição Especial, 2009, pp. 59 70 .

PEREIRA, José Roberto. "Visões mediadoras e o papel dos diagnósticos participativos na organização de assentamentos rurais". Revista de Administração da UFLA - Organizações Rurais e Agroindustriais. V.3 - N. 2 - Jul./Dez. - 2001, pp.3-11.

PIDNER, Flora Sousa. Diálogos entre ciência e saberes locais: dificuldade e perspectivas. Belo Horizonte: Universidade Federal Minas Gerais, Instituto de Geociências, Programa de Pós-graduação em Geografia, 2010 (Dissertação de Mestrado).

PIRES, Maria do Carmo. "O Termo de Vila de Nossa Senhora do Carmo/Mariana e suas freguesias no século XVIII". In: CHAVES, Cláudia M. das Graças; PIRES, Maria do Carmo; MAGAlHÃES, Sônia Maria de (Orgs.). Casa de Vereança de Mariana: 300 anos de História da Câmara Municipal. Ouro Preto: Edufop/PPGHIS, 2012.

POLLAK, Michael. "Memória, Esquecimento e Silêncio". In: Estudos Históricos, Rio de Janeiro, vol. 2, nº 3, 1989, p.3-15.

POLLAK, Michael. "Memória e identidade social". In: Estudos Históricos, Rio de Janeiro, vol. $5, \mathrm{n}^{\circ} 10,1992$, p. 200-212.

PRADO JR, Caio. A Questão Agrária do Brasil. Editora Brasiliense. $3^{\text {a }}$ Edição. 1981, p.192.

PREZIA, Benedito; HOORNAERT, Eduardo. Brasil indígena: 500 anos de resistência. São Paulo: FTD, 2000, s.n.t.

QUIJANO, Aníbal. Colonialidade, poder, globalização e democracia. Revista NOVOS RUMOS, Ano 17, Número 37, 2002.

RAMIRO, Patrícia Alves. Versões da reforma agrária: a mídia e o MST numa ocupação de terra no Pontal. Universidade Estadual de Londrina, Grupo de Estudos de Política da América Latina, Segundo Simpósio, GT6 Estado, meios de comunicação e movimentos sociais, 2010. 
REZENDE, Gervásio Castro de. Políticas trabalhista e fundiária e seus efeitos adversos sobre o emprego agrícola, a estrutura agrária e o desenvolvimento territorial rural no Brasil. Rio de Janeiro: Instituto de Pesquisa Econômica Aplicada, Ipea, 2005. (Texto para discussão). ISSN 1415-4765.

ROSSETTO, Elisabeth. BRABO, Gabriela. A constituição do sujeito e a subjetividade a partir de Vygotsky: algumas reflexões. Revista Travessias. Edição 05, 2009, 11p. ISSN 19825935 .

RÚBIO, Rúbia de Paula. Em busca de sombras que não obscurecem uma luta: narrativas de vidas espaciais dos assentados e assentamento Cafundão, Mariana-MG. Licenciatura em Geografia. Instituto Federal de Educação, Ciência e Tecnologia de Minas Gerais Campus Ouro Preto, novembro de 2012.

SANTANA, Paulo Vinicius Silva. Ministério Sacerdotal na Sé de Mariana: posse de livros, organização familiar e atividades econômicas (1820 a 1875). Belo Horizonte: PósGraduação em História, Faculdade de Filosofia e Ciências Humanas da Universidade Federal de Minas Gerais, 2011, 146p. (Dissertação).

SANTOS, Milton. O Universal e o Particular: a Atualidade. In: A Natureza do Espaço: Técnica e Tempo, Razão e Emoção / Milton Santos. - 4. ed. 2. reimpr. - São Paulo: Editora da Universidade de São Paulo, 2006.

SANTOS, Rafael de Oliveira Coelho dos. O que teve de reforma agrária no governo Lula? TERRITÓRIO: revista de geografia agrária, v. 6, n. 12, p. 63-78, ago., 2011.

SALLES, José Carlos de Moraes. Usucapião de bens imóveis e móveis. $7^{a}$ edição. São Paulo: Revista dos Tribunais. 2010, p 200-230. ISBN: 978-85-203-3672-4.

SCHNEIDER, Sérgio. Teoria Social, Agricultura Familiar e Pluriatividade. Revista Brasileira de Ciências Sociais - Vol 18, nº 51, fevereiro de 2003, p.99-122.

SEEMANN, Jörn. O espaço da memória e a memória do espaço: algumas reflexões sobre a visão espacial nas pesquisas sociais e históricas. Revista da Casa da Geografia de Sobral, Sobral, v. 4/5, p. 43-53, 2003.

SEVÁ, Oswaldo. Mina Grande Conflitos Gerais. Gesta, UFMG, 2011, 27p.

SIGAUD, Lygia. As condições de possibilidade das ocupações de terra. Tempo Social, Revista de sociologia da USP, v. 17, n. 1, pp. 255-280.

SILVA, Calos Eduardo Mazzeto. A dinâmica dos projetos de assentamento de reforma agrária na Região Metropolitana de Belo Horizonte. XVI Encontro Nacional de Estudos Populacionais, ABEP, realizado em CaxambuMG - Brasil, de 29 de setembro a 03 de outubro de 2008. 
SILVA, Gustavo Melo. TANNÚS, Marcos Bartasson. MOREIRA, Ceres Virgínia Rennó. (2006). Economia e sociedade no sistema de produção mínero-artesanal. XIII SIMPEP Bauru, SP, Brasil, 06 a 08 de novembro de 2006.

SILVA, José Graziano da. O que é questão agrária. São Paulo: Editora Brasiliense, 2001. (Coleção Primeiros Passos).

SILVEIRA, Lidiane Nunes. NETO, José Ambrósio F., FIÚZA, Ana Louise C.; DOULA, Sheila Maria. O Pântano do Cururu: terra, trabalho e conflito. Oikos, Viçosa, v. 20, n. 1, p. 139-157, 2009.

SINGER, Paul. Cooperativismo e sindicatos no Brasil. In: CUT BRASIL. Sindicalismo e economia solidária: reflexões sobre o projeto da CUT. São Paulo: CUT, 1999. p. 23-28.

SOLARI, Aldo. O objeto da sociologia rural. In: SZMRECSÁNYI, Tamás. QUEDA, Oriowaldo. Vida Rural e Mudança Social: leituras básicas da sociologia rural, Companhia Editora Nacional, \#a edição, 2006. p. 03-27.

SOROKIN, Pitirim A.; ZIMMERMAN, Carlo C.; GALPIN, Charles J. (1986), "Diferenças fundamentais entre o mundo rural e o urbano". In: MARTINS, José de S. (org.). Introdução crítica à sociologia rural. 2. ed., São Paulo: Hucitec.

SOUSA, Patrício Pereira Alves de. As geo-grafias da memória: o lugar festivo como biografia espacial. R. RA'E GA, Curitiba, n. 20, p. 81-93, 2010. Editora UFPR.

SPAROVEK, Gerd. A Qualidade dos Assentamentos da Reforma Agrária Brasileira. São Paulo: Páginas \& Letras, Editora e Gráfica, 2003. 218pp.

STÉDILE, João Pedro. FERNANDES, Bernardo Mançano. Brava gente: A trajetória do MST e a luta pela terra no Brasil. 1a edição: agosto de 1999. São Paulo: Editora Fundação Perseu Abramo, 3a reimpressão: setembro de 2005, 168p. ISBN 85-86469-17-3.

SUZUKI, Júlio César. Questão agrária na América Latina: renda capitalizada como instrumento de leitura da dinâmica sócio-espacial. . En publicación: América Latina: cidade, campo e turismo. Amalia Inés Geraiges de Lemos, Mónica Arroyo, María Laura Silveira. CLACSO, Consejo Latinoamericano de Ciencias Sociales, San Pablo. Diciembre 2006.

Campo e cidade no Brasil: transformações socioespaciais e dificuldades de conceituação. REVISTA NERA - ANO 10, N. 10 - JANEIRO/JUNHO DE 2007 - ISSN: 1806-6755

TRINDADE, Cônego Raimundo. Instituições de igrejas no bispado de Mariana. Rio de Janeiro: Ministério da Educação e Saúde, 1945, p. 65.

TURATTI. Maria Cecília Manzoli. Acampamentos do MST: uma discussão crítica sobre a sociabilidade e poder. XXIII Encontro Anual da ANPOCS, Caxambu, MG, outubro de 1999, $30 \mathrm{p}$. 
VEIGA, José Eli da. O Brasil é menos urbano do que se calcula. In: Cidades Imaginárias: o Brasil é menos urbano do que se calcula. 2.ed. Campinas: Autores Associados, 2003a. pp. 63-67.

. Herança de Caio Prado Jr. In: Cidades Imaginárias: o Brasil é menos

urbano do que se calcula. 2.ed. Campinas: Autores Associados, 2003b. pp. 117-120.

VERDEJO, Miguel Expósito. Diagnóstico rural participativo: guia prático DRP. Revisão e adequação: Décio Cotrim e Ladjane Ramos. Brasília: MDA / Secretaria da Agricultura Familiar, 2006, 62 p: il.

VINHAS, Moisés. Problemas agrario-camponeses do Brasil. $2^{\text {a }}$ Edição. Rio de Janeiro: Civilização Brasileira, 1972.

\section{REFERÊNCIAS DOCUMENTAIS}

AGÊNCIA BRASIL. Assentados mineiros recebem títulos de posse amanhã. Brasília, 12 de setembro de 2002a, $18 \mathrm{~h} 09$.

AGÊNCIA BRASIL. Incra entrega títulos a famílias assentadas na cidade de Mariana. Brasília, 19 de setembro de 2002b, 9h34.

ANGELO, Vitor Amorim. Lei de Terras: Lei de 1850 contribui para manter concentração fundiária. UOL Educação: Especial Pedagogia \& Comunicação. História do Brasil. Vitor Amorim de Angelo. 05 de dezembro de 2007. 11h49.

ARQUIDIOCESE DE SÃO PAULO. Pesquisa "Brasil: Nunca Mais". São Paulo: Faculdade de Direito da Universidade de São Paulo, Biblioteca Central, 1985. Disponível em: http://www.dhnet.org.br/memoria/nuncamais/bnm_tomo1_regime_militar.pdf. Acesso em: 15 de janeiro de 2015.

ASSEMBLÉIA LEGISLATIVA DO ESTADO DE MINAS GERAIS. Comissões: Cafundão. Departamento de Comunicação Social. Número 217. 24 de junho de 1992, página 08. Disponível em: dspace.almg.gov.br/xmlui/bitstream/handle/11037/8057/n.217.pdf?. Acesso em: 21 de dezembro de 2015.

BRASIL. COMISSÃO NACIONAL DA VERDADE. Dinâmica das graves violações de direitos humanos: casos emblemáticos, locais e autores O Judiciário. Relatório. Dezembro de 2014a. Volume I, Parte IV. p. 593 - 958. Disponível em: http://www.cnv.gov.br/images/relatorio_final/Relatorio_Final_CNV_Parte_4.pdf. Acesso em 15 de janeiro de 2015.

BRASIL. COMISSÃO NACIONAL DA VERDADE. Violações de direitos humanos dos camponeses. Relatório: textos temáticos / Comissão Nacional da Verdade. - Brasília: CNV, Volume II, 2014b. p. 87-151. Disponível em: 
http://www.cnv.gov.br/images/relatorio_final/Relatorio_Final_CNV_Volume_II.pdf. Acesso em: 19 de janeiro de 2015.

BRASIL. Carta-Lei de 25 de março de 1824. Manda observar a Constituição Política do Império, offerecida e jurada por Sua Magestade o Imperador. Disponível em: http://www.planalto.gov.br/Ccivil_03/Constituicao/Constituicao24.htm Acesso em 13 de fevereiro de 2014.

BRASIL. Decreto n ${ }^{0} 1.318$ de 30 de janeiro de 1854. Manda executar a Lei ${ }^{\circ} 601$, de 18 de setembro de 1850. Disponível em: http://www.planalto.gov.br/CCIVIL_0 3/decreto/Historicos/DIM/DIM1318.htm . Acesso em: 13 de fevereiro de 2014.

BRASIL. Lei $\mathbf{n}^{0}$ 581, de 04 de setembro de 1850. Estabelece medidas para a repressão do trafico de africanos neste Imperio. Disponível em: http://www.planalto.gov.br/ccivil_03/Leis/LIM/LIM581.htm. Acesso em 26 de agosto de 2014.

BRASIL. Lei $\mathbf{n}^{0}$ 601, de 18 de setembro de 1850. Dispõe sobre as terras devolutas do Império. Disponível em: http://www.planalto.gov.br/ccivil_03/Leis/L0601-1850.htm. Acesso em 13 de fevereiro de 2014.

BRASIL. Ministério do Desenvolvimento Agrário. Coletânea de legislação e jurisprudência agrária e correlata. Organizadores: Joaquim Modesto Pinto Junior, Valdez Farias. -Brasília: Ministério do Desenvolvimento Agrário, Núcleo de Estudos Agrários e Desenvolvimento Rural, 2007 (NEAD Especial; 7). 3 volumes. ISBN 978-85-60548-16-3.

BRASIL. DIÁRIO OFICIAL DA UNIÃO. Superintendência Regional de Minas Gerais. PORTARIA DE 12 DE MARÇO DE 1992. Seção 1, quarta-feira, 18 de março de 1992, p. 1674.

BRASIL. DIÁRIO OFICIAL DA UNIÃO. Superintendência Regional de Minas Gerais. PORTARIA DE No- 09, DE 21 DE JANEIRO 1993a. Seção 1, No 18, quarta-feira, 27 de janeiro de 1993, p. 1180.

BRASIL. DIÁRIO OFICIAL DA UNIÃO. Superintendência Regional de Minas Gerais. PORTARIA DE 24 DE JUNHO DE 1993b. Seção 02, no 344, sexta-feira, 25 de junho de 1993, p. 3482.

BRASIL. DIÁRIO OFICIAL DA UNIÃO. Superintendência Regional de Minas Gerais. PORTARIA No- 05, DE 08 DE FEVEREIRO DE 1995. Seção 1, Nº 34, quinta-feira, 16 de fevereiro de 1995, p. 2078.

BRASIL. DIÁRIO OFICIAL DA UNIÃO. Superintendência Regional de Minas Gerais. RESOLUÇÃO No- 18, DE 12 DE DEZEMBRO DE 2001. Seção 1, No 8, sexta-feira, 11 de janeiro de 2002, ISSN 1676-2339, p. 111. 
BRASIL DE FATO. 75 anos dos levantes antifascistas. Por Anita Leocadia Prestes. 19 de novembro de 2010. Disponível em: http://www.brasildefato.com.br/node/5093. Acesso em: 13 de novembro de 2014.

CÂMARA MUNICIPAL DE MARIANA. Atas de Reunião Ordinária e Extraordinária da Câmara Municipal de Mariana. LIVRO DAS ATAS DAS REUNIÕES DA CÂMARA MUNICIPAL DE MARIANA, ORDINÁRIAS E EXTRAORDINÁRIAS. LIVRO 10: 30 DE NOVEMBRO DE 1989 A 17 DE AGOSTO DE 1992.

CETEC-MG. Avaliação das Condições Existentes para a Estruturação do Desenvolvimento Regional Auto Sustentado, baseado na Metodologia de APL's, nos Municípios de Ouro Preto, Mariana e Catas Altas da Noruega (MG). Belo Horizonte, Responsável técnico: Rodolfo Koeppel, 53p (Relatório técnico).

COMARCA DE MARIANA. Serviço Registral de Imóveis. Mariana, 30 de dezembro de 1991, Livro 2-X, página 20. [Datilografado]

CONSULTOR JURIDICO. Registro paroquial não comprova posse de terras. Caderno Propriedade púbica. 25 de junho de 2009, 02h07. Disponível: http://www.conjur.com.br/2009-jun-25/registro-paroquial-nao-comprova-posse-terras-uniao.

Acesso em: 28 de agosto de 2014.

EMPRESA BRASILEIRA DE PESQUISA AGROPECUÁRIA. Variação geográfica do tamanho dos módulos fiscais no Brasil / Elena Charlotte Landau ... [et al.]. Sete Lagoas: Embrapa Milho e Sorgo, 2012. 199 p.

INSTITUTO BRASILEIRO DE GEOGRAFIA E ESTATÍSTICA. Censo agropecuário. Rio de janeiro, 2006, p. 1-146. ISSN 0103-6157

MINISTÉRIO DO DESENVOLVIMENTO AGRÁRIO. III Agriminas destaca produtos da agricultura familiar. Brasília, 09 de setembro de 2008, 07h07. Disponível em: http://portal.mda.gov.br/portal/noticias/item?item_id=3586219. Acesso em 15 de janeiro de 2014.

MONUMENTO, O. Prefeito busca solução para o conflito no Cafundão. Ano VII. Número 58. Outubro de 1990, p. 03.

NERA - Núcleo de Estudos, Pesquisas e Projetos de Reforma Agrária - FCT/ UNESP Coordenação: FERNANDES, Bernardo Mançano. Presidente Prudente, São Paulo. Janeiro de 2006. DATALUTA - Banco de Dados da Luta pela Terra: Relatório 2004. http://www.lagea.ig.ufu.br/rededataluta/relatorios/brasil/dataluta_brasil_2004.pdf.

NERA - Núcleo de Estudos, Pesquisas e Projetos de Reforma Agrária - FCT/ UNESP Coordenação: FERNANDES, Bernardo Mançano. Presidente Prudente, São Paulo. Dezembro de 2006. DATALUTA - Banco de Dados da Luta pela Terra: Relatório 2005. http://www.lagea.ig.ufu.br/rededataluta/relatorios/brasil/dataluta_brasil_2005.pdf. 
NERA - Núcleo de Estudos, Pesquisas e Projetos de Reforma Agrária - FCT/ UNESP Coordenação: FERNANDES, Bernardo Mançano. Presidente Prudente, São Paulo. Novembro de 2007. DATALUTA - Banco de Dados da Luta pela Terra: Relatório 2006. http://www.lagea.ig.ufu.br/rededataluta/relatorios/brasil/dataluta_brasil_2006.pdf.

NERA - Núcleo de Estudos, Pesquisas e Projetos de Reforma Agrária - FCT/ UNESP Coordenação: FERNANDES, Bernardo Mançano. Presidente Prudente, São Paulo. Agosto de 2008. DATALUTA - Banco de Dados da Luta pela Terra: Relatório 2007. http://www.lagea.ig.ufu.br/rededataluta/relatorios/brasil/dataluta_brasil_2007.pdf.

NERA - Núcleo de Estudos, Pesquisas e Projetos de Reforma Agrária - FCT/ UNESP Coordenação: FERNANDES, Bernardo Mançano. Presidente Prudente, São Paulo. Dezembro de 2009. DATALUTA - Banco de Dados da Luta pela Terra: Relatório 2008. http://www.lagea.ig.ufu.br/rededataluta/relatorios/brasil/dataluta_brasil_2008.pdf.

NERA - Núcleo de Estudos, Pesquisas e Projetos de Reforma Agrária - FCT/ UNESP Coordenação: FERNANDES, Bernardo Mançano. Presidente Prudente, São Paulo. Setembro de 2010. DATALUTA - Banco de Dados da Luta pela Terra: Relatório 2009. http://www.lagea.ig.ufu.br/rededataluta/relatorios/brasil/dataluta_brasil_2009.pdf.

NERA - Núcleo de Estudos, Pesquisas e Projetos de Reforma Agrária - FCT/ UNESP Coordenação: FERNANDES, Bernardo Mançano. Presidente Prudente, São Paulo. Outubro de 2011. DATALUTA - Banco de Dados da Luta pela Terra: Relatório 2010. http://www.lagea.ig.ufu.br/rededataluta/relatorios/brasil/dataluta_brasil_2010.pdf.

NERA - Núcleo de Estudos, Pesquisas e Projetos de Reforma Agrária - FCT/ UNESP Coordenação: FERNANDES, Bernardo Mançano. Presidente Prudente, São Paulo. Outubro de 2012. DATALUTA - Banco de Dados da Luta pela Terra: Relatório 2011. http://www.lagea.ig.ufu.br/rededataluta/relatorios/brasil/dataluta_brasil_2011.pdf.

NERA - Núcleo de Estudos, Pesquisas e Projetos de Reforma Agrária - FCT/ UNESP Coordenação: FERNANDES, Bernardo Mançano. Presidente Prudente, São Paulo. Dezembro de 2013. DATALUTA - Banco de Dados da Luta pela Terra: Relatório 2012. http://www.lagea.ig.ufu.br/rededataluta/relatorios/brasil/dataluta_brasil_2012.pdf.

PRESTES, Luiz Carlos. Manifesto da Aliança Nacional Libertadora. 05 de julho de 1935. Transcrito por Fernando A. S. Araújo, maio de 2006. Disponível em: http://www.marxists.org/portugues/prestes/1935/07/05.htm. Acesso em: 13 de novembro de 2014.

SISTEMA INSTITUCIONAL DO PROGRAMA DE REFORMA AGRÁRIA. MDA: Relatório 0227, de 18 de agosto de 2011.

SISTEMA INSTITUCIONAL DO PROGRAMA DE REFORMA AGRÁRIA. MDA: Rel_rb_PNRA, de 12 de maio de 2014

TERMO DE AUDIÊNCIA DO PODER JUDICIÁRIO DE MINAS GERAIS. Processo número 0016202-87.1997.8.13.0400. 26 de abril de 2004. (Datilografado) 